\title{
VOLATILE-MEDIATED \\ ARTHROPOD-FUNGUS INTERACTIONS
}

\author{
Dissertation \\ zur Erlangung des mathematisch-naturwissenschaftlichen Doktorgrades \\ "Doctor rerum naturalium" \\ der Georg-August-Universität Göttingen
}

im Promotionsprogramm Biologie

der Georg-August University School of Science (GAUSS)

vorgelegt von

\section{LAURA STÖTEFELD}

aus Hannover

Göttingen, Oktober 2018 


\section{BETREUUNGSAUSSCHUSS}

Prof. Dr. Marko Rohlfs, Abteilung Populations- und Evolutionsökologie, Institut für Ökologie der Universität Bremen, Leobener Str. 5, 28359 Bremen

Prof. Dr. Stefan Scheu, Abteilung Tierökologie, J.F. Blumenbach Institut für Zoologie und Anthropologie der Georg-August-Universität Göttingen, Untere Karspüle 2, 37073 Göttingen

\section{Mitglieder DER PRÜFUNGSKOMMISSION}

Referent/in: Prof. Dr. Marko Rohlfs, Abteilung Populations- und Evolutionsökologie, Institut für Ökologie der Universität Bremen, Leobener Str. 5, 28359 Bremen

Koreferent/in: Prof. Dr. Stefan Scheu, Abteilung Tierökologie, J.F. Blumenbach Institut für Zoologie und Anthropologie der Georg-August-Universität Göttingen, Untere Karspüle 2, 37073 Göttingen

\section{WEITERE MITGLIEDER DER PRÜFUNGSKOMMISSION}

Prof. Dr. Mark Maraun, Abteilung Tierökologie, J.F. Blumenbach Institut für Zoologie und Anthropologie der Georg-August-Universität Göttingen, Untere Karspüle 2, 37073 Göttingen

PD Dr. Klaus Hövemeyer, Abteilung Tierökologie, J.F. Blumenbach Institut für Zoologie und Anthropologie der Georg-August-Universität Göttingen, Untere Karspüle 2, 37073 Göttingen

Prof. Dr. Petr Karlovsky, Abteilung Molekulare Phytopathologie und Mykotoxinforschung, Fakultät für Agrarwissenschaften der Georg-August-Universität Göttingen, Büsgenweg 5, 37077 Göttingen

PD Dr. Dirk Gansert, Abteilung Pflanzenökologie und Ökosystemforschung, Albrecht-von-Haller-Institut für Pflanzenwissenschaften der Georg-August-Universität Göttingen, Untere Karspüle 2, 37073 Göttingen 
'MAN IS NATURE BECOMING AWARE OF ITSELF' (JACQUES ÉlisÉE RECLUS)

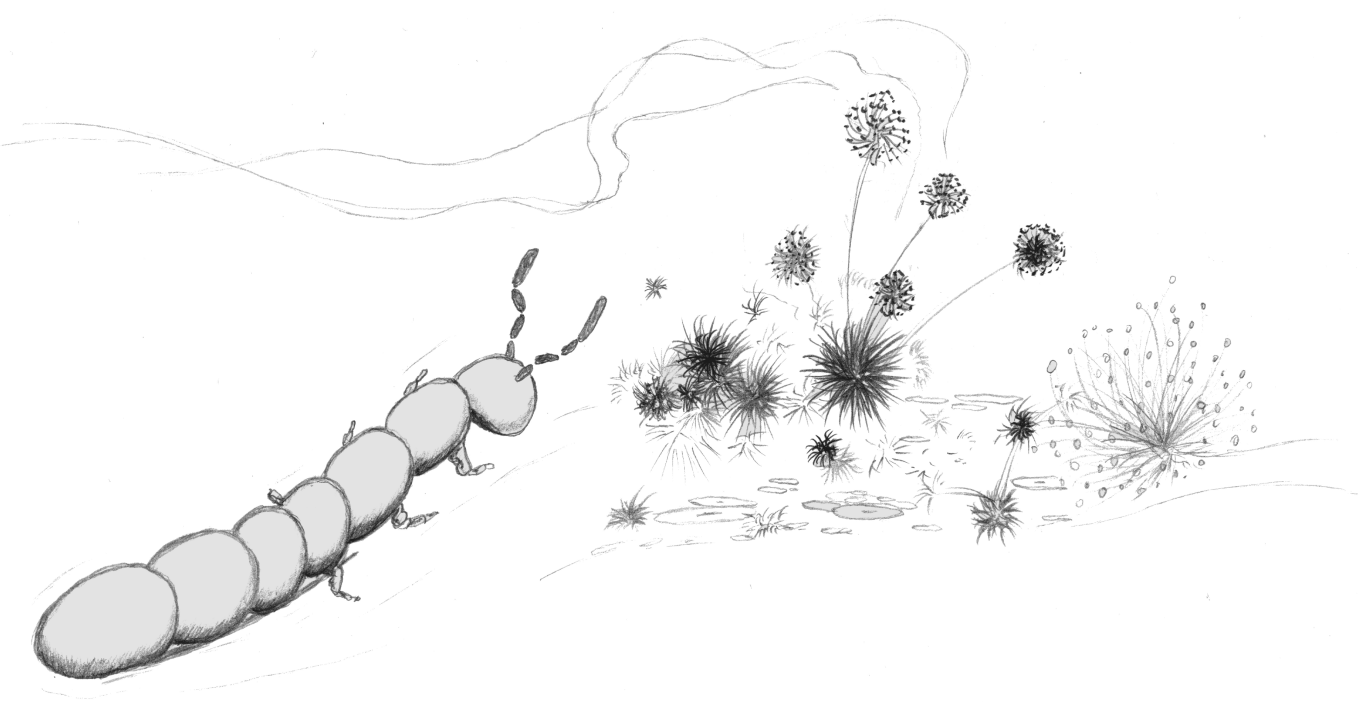




\section{LIST OF CONTENTS}

\begin{tabular}{lll}
\hline LIST OF FIGURES & $\mathrm{V}$
\end{tabular}

LIST OF TABLES

SUMMARY 1

1 A REVIEW OF THE ROLE OF FUNGAL VOLATILES AS INFOCHEMICALS IN INVERTEBRATE-FUNGUS INTERACTIONS 3

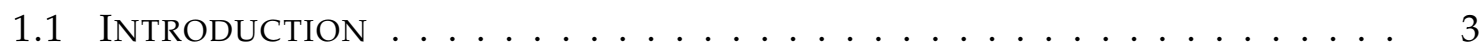

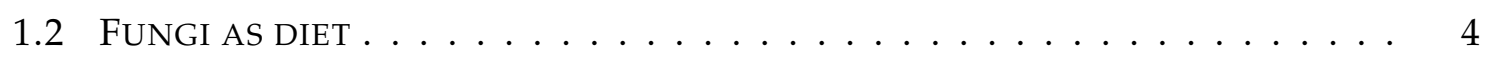

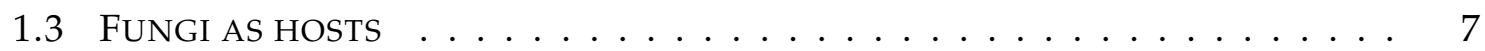

1.4 FUNGAL NICHE CONSTRUCTION $\ldots \ldots \ldots \ldots \ldots \ldots$

1.5 FUNGI AS PATHOGENS \& PREDATORS . . . . . . . . . . . . . . . . . 10

1.6 FUNGI IN A MULTITROPHIC CONTEXT . . . . . . . . . . . . . . . . . . 11

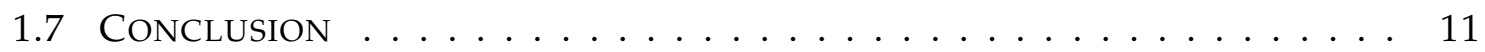

\begin{tabular}{ll}
\hline REFERENCES & 31
\end{tabular}

SUBJECT OF THE PRESENT PHD PROJECT 32

2 WOUND-ACTIVATED FUNGAL OXYLIPIN VOLATILES FUNCTION AS INFOCHEMICALS FOR COLLEMBOLA 33

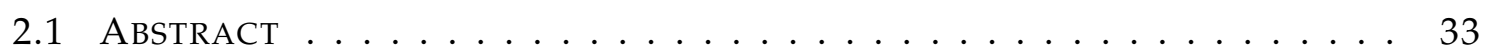

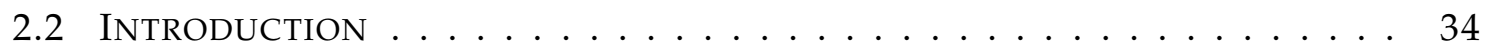

2.3 MATERIAL AND METHODS. . . . . . . . . . . . . . . . . . . . . 36

2.3 .1 CULTIVATION OF COLLEMBOLA AND C. globosum . . . . . . . . . . . . . 36

$\begin{array}{lll}2.3 .2 & \text { SAMPLING, IDENTIFICATION, AND QUANTIFICATION OF C. globosum VOLATILES } 37\end{array}$

2.3 .3 SELECTION OF VARIABLES FOR CHARACTERISATION OF COLLEMBOLA RE-

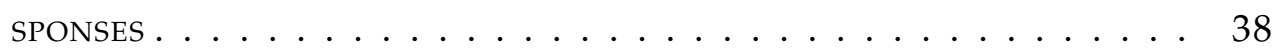

2.3 .4 EXPERIMENTAL SETUP $\ldots \ldots \ldots \ldots \ldots$. . . . . . . . . . . . . 42

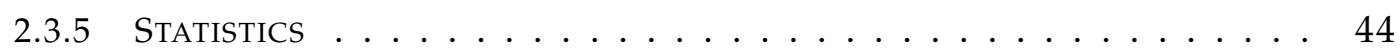

$2.4 \quad$ RESULTS $\ldots \ldots \ldots \ldots \ldots \ldots$

$\begin{array}{lll}2.4 .1 & \text { VOLATILE PROFILES OF UNWOUNDED AND WOUNDED C. globosum COLONIES } & 46\end{array}$

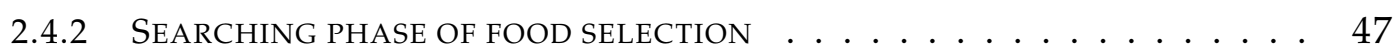

2.4 .3 CONTACT PHASE OF FOOD SELECTION $\ldots \ldots \ldots$. . . . . . . . . . 47

2.4 .4 'SUBSTRATE BITING' BEHAVIOUR OF F. candida AND S. curviseta . . . . . . . . 50

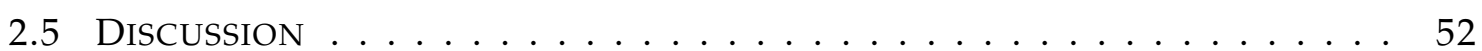


\begin{tabular}{ll}
\hline REFERENCES & 61
\end{tabular}

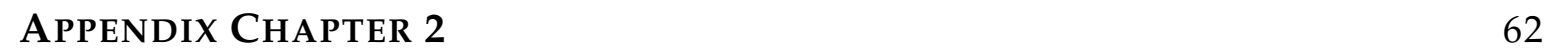

3 FUNGAL VOLATILES MODULATE THE SPATIAL FORAGING BEHAVIOUR OF THE COMMON WOODLOUSE (Oniscus asellus)

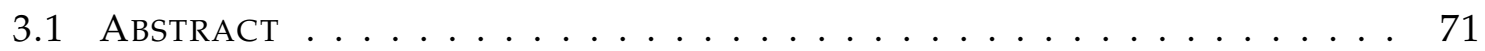

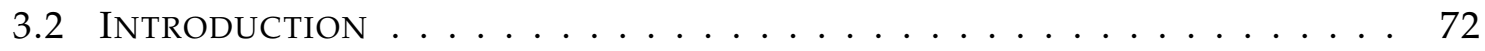

3.3 MATERIAL AND METHODS . . . . . . . . . . . . . . . . . . . . . . . . 74

3.3.1 FIELD COLLECTION OF O. asellus AND CULTIVATION OF C. globosum . . . . . 74

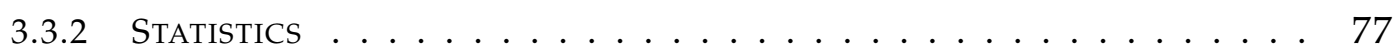

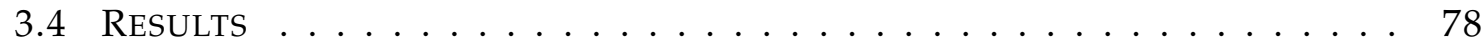

3.4 .1 ISOPOD MOVEMENT PATTERNS IN RESPONSE TO UNWOUNDED AND WOUNDED C. globosum COLONIES . . . . . . . . . . . . . . . . . . 78

3.4 .2 ISOPOD MOVEMENT PATTERNS IN RESPONSE TO AUTHENTIC COMPOUNDS 3-OCTANONE AND 3-METHYL-1-BUTANOL . . . . . . . . . . . . . 79

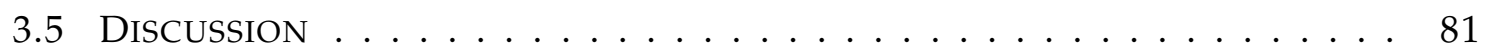

\begin{tabular}{lr}
\hline REFERENCES & 88
\end{tabular}

4 VOLATILE-MEDIATED FORAGING RESPONSES TO YEASTS AND FILAMENTOUS FUNGI CORRELATE WITH FUNGIVORE GROWTH AND REPRODUCTION 89

4.1 ABSTRACT $\ldots \ldots \ldots \ldots \ldots \ldots$

4.2 INTRODUCTION $\ldots \ldots \ldots \ldots \ldots \ldots \ldots \ldots$

4.3 MATERIAL AND METHODS $\ldots \ldots \ldots \ldots$

4.3 .1 FUNGAL INCUBATION $\ldots \ldots \ldots \ldots \ldots \ldots \ldots$

4.3 .2 CULTURING OF F. candida COLLEMBOLA $\ldots \ldots \ldots \ldots \ldots$

4.3 .3 SPME-GC-MS VOLATILE PROFILING . . . . . . . . . . . . . . . . . . . 95

4.3 .4 AUTHENTIC STANDARDS FROM COMMERCIAL SUPPLIERS . . . . . . . . . 97

4.3 .5 EXPERIMENTAL SETUPS $\ldots \ldots \ldots \ldots$. . . . . . . . . . . . . . . 97

4.3.6 SELECTION OF VARIABLES FOR CHARACTERISATION OF COLLEMBOLA FORAGING RESPONSES ． . . . . . . . . . . . . . . . . . . . . . . 101

4.3 .7 STATISTICAL ANALYSIS $\ldots \ldots \ldots \ldots$

4.4 RESULTS $\ldots \ldots \ldots \ldots \ldots$

4.4 .1 GC-MS ANALYSIS - COMPARISON OF VOLATILE PROFILES … . . . . . 105

4.4 .2 THE SEARCHING PHASE OF FOOD SELECTION $\ldots \ldots \ldots$. . . . . . . . . 107

4.4 .3 CONTACT BEHAVIOUR OF F. candida $\ldots \ldots \ldots \ldots$

4.4 .4 EFFECT OF DIFFERENT FUNGAL DIETS ON COLLEMBOLA FITNESS. . . . . . . 121

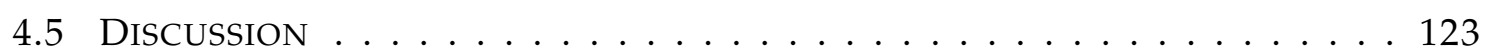

4.5 .1 COLLEMBOLA RESPONSES TO FILAMENTOUS FUNGI . . . . . . . . . . . . . . 124 
4.5.2 COLLEMBOLA RESPONSES TO WOUND-ACTIVATED CHANGES IN FILAMENTOUS FUNGI . . . . . . . . . . . . . . . . . . . . . 125

4.5 .3 COLLEMBOLA RESPONSES TO UNICELLULAR YEASTS . . . . . . . . . . . 126

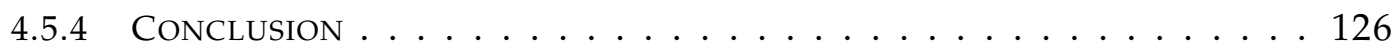

\begin{tabular}{ll}
\hline REFERENCES & 133
\end{tabular}

\begin{tabular}{ll}
\hline APPENDIX CHAPTER 4 & 134
\end{tabular}

5 FINAL DISCUSSION 149

5.1 THE ROLE OF FUNGAL VOLATILE OXYLIPINS IN MODULATING THE FORAGING BEHAVIOUR OF FUNGIVOROUS ARTHROPODS $\ldots$. . . . . . . . . . . . . . . 150

5.2 COLLEMBOLA DISTINGUISH BETWEEN SUITABLE AND LESS SUITABLE FUNGAL FOOD SOURCES BY MEANS OF VOLATILES $\ldots \ldots \ldots$. . . . . . . . 151

5.3 CONCLUSION AND OUTLOOK $\ldots \ldots \ldots \ldots \ldots \ldots \ldots \ldots$

\begin{tabular}{lr}
\hline REFERENCES & 159
\end{tabular}

\begin{tabular}{ll}
\hline DANKSAGUNG & 160
\end{tabular}

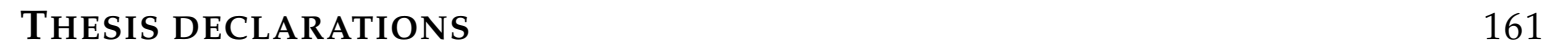

DECLARATION OF THE AUTHOR'S OWN CONTRIBUTION TO MANUSCRIPTS WITH MULTIPLE AUTHORS $\ldots \ldots \ldots \ldots \ldots \ldots \ldots 16 \ldots \ldots \ldots$

PLAGIARISM DECLARATION $\ldots \ldots \ldots \ldots \ldots \ldots \ldots \ldots$ 


\section{LIST OF FIGURES}

1.1 INTERACTION TYPES CATEGORISED BY THE EFFECT POTENTIALLY MEDIATED BY VOLATILE

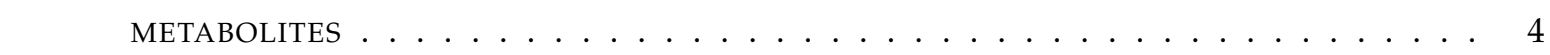

2.1 MACRO PHOTOGRAPHS OF F. candida FEEDING/BITING PATTERNS IN THE PRESENCE OF

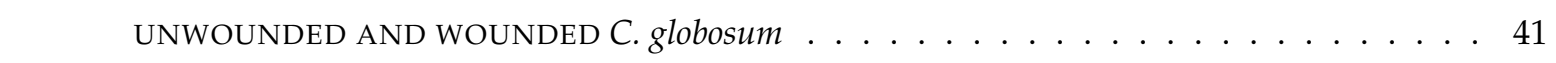

2.2 EXPERIMENTAL SETUP FOR OBSERVATION OF COLLEMBOLA MOVEMENT $\ldots \ldots \ldots$. . . . . 43

2.3 HEADSPACE CONCENTRATIONS (NG/ $\mathrm{CM}^{3}$ ) OF C. globosum-DERIVED VOLATILE COM-

POUNDS 3-OCTANONE, 3-OCTYL ACETATE, AND 3-METHYL-1-BUTANOL . . . . . . . . . 46

2.4 NUMBER OF 'SUBSTRATE BITING' EVENTS OF F. candida AND S. curviseta IN RESPONSE

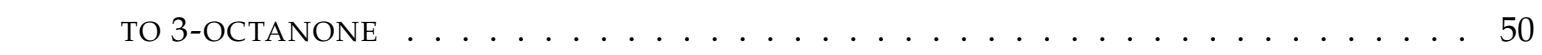

2.5 MACRO PHOTOGRAPHS OF BITING MARKS OF F. candida AND S. curviseta IN THE PRES-

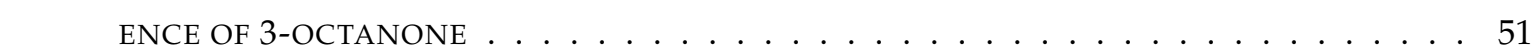

A.2.1 CALIBRATION PLOTS FOR AUTHENTIC VOLATILE COMPOUNDS 3-OCTANONE, 3-OCTYL

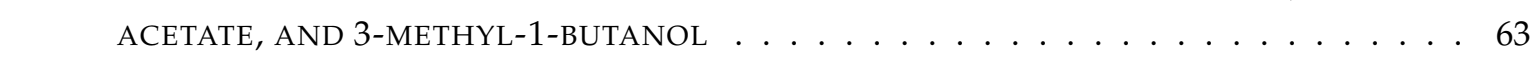

A.2.2 TOTAL ION CURRENT (TIC) CHROMATOGRAMS OF UNWOUNDED AND WOUNDED C. glo-

boSUm COLONIES AND FUNGAL-FREE MEA CONTROLS . . . . . . . . . . . . . . . . 64

A.2.3 VERIFICATION OF NO-CHOICE OLFACTOMETER ARENA FUNCTIONING FOR THE DETEC-

TION OF COLLEMBOLA ATTRACTING OR ARRESTING VOLATILE SOURCES $\ldots$. . . . . . 65

A.2.4 SEARCHING PHASE: KAPLAN MEIER CURVES FOR F. candida, H. nitidus, AND S. curviseta

'LATENCY TO THE FIRST ARRIVAL AT CENTRAL ZONES' IN RESPONSE TO UNWOUNDED

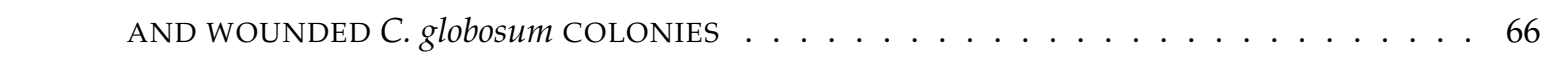

A.2.5 SEARCHING PHASE: KAPLAN MEIER CURVES FOR F. candida, H. nitidus, AND S. curviseta

'DURATION OF THE FIRST CENTRAL ZONE VISIT' (DEPARTURE TENDENCY) IN RESPONSE

\begin{tabular}{|l}
\hline TO UNWOUNDED AND WOUNDED C. globosum COLONIES $\ldots \ldots \ldots$ \\
\hline
\end{tabular}

A.2.6 SEARCHING PHASE: F. candida, H. nitidus, AND S. curviseta 'RESIDENCE TIME IN CEN-

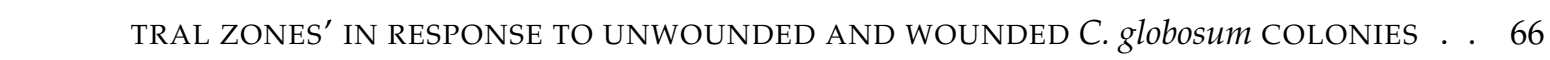

A.2.7 SEARCHING PHASE: F. candida, H. nitidus, AND S. curviseta 'MEAN DURATION OF CEN-

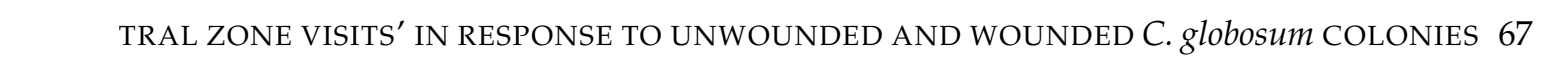

A.2.8 CONTACT PHASE: 'TOTAL NUMBER OF FEEDING EVENTS' OF F. candida, H. nitidus, AND

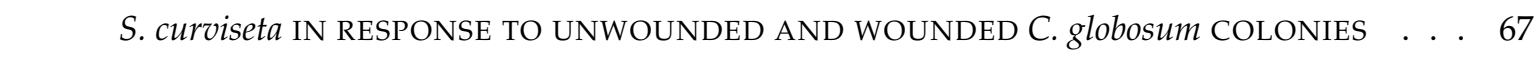

A.2.9 CONTACT PHASE: 'COLONY CONTACT FREQUENCY PRIOR TO THE FIRST FEEDING EVENT' OF F. candida, H. nitidus, AND S. curviseta IN RESPONSE TO UNWOUNDED AND WOUNDED

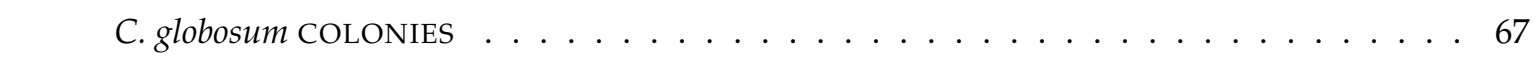

A.2.10 CONTACT PHASE: 'CONTACT TIME' (\%) OF F. candida, H. nitidus, AND S. curviseta IN

RESPONSE TO UNWOUNDED AND WOUNDED C. globosum COLONIES . . . . . . . . . . 68

A.2.11 CONTACT PHASE: F. candida, H. nitidus, AND S. curviseta 'MEAN DURATION OF COLONY

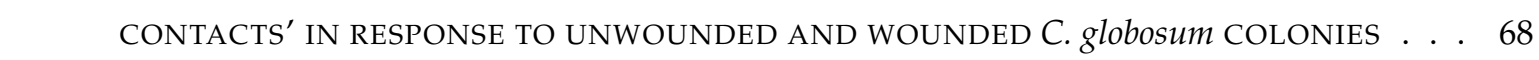

A.2.12CONTACT PHASE: 'FEEDING TIME' (\%) OF F. candida, H. nitidus, AND S. curviseta IN

RESPONSE TO UNWOUNDED AND WOUNDED C. globosum COLONIES . . . . . . . . . . . 68

A.2.13 CONTACT PHASE: F. candida, H. nitidus, AND S. curviseta 'MEAN DURATION OF FEEDING

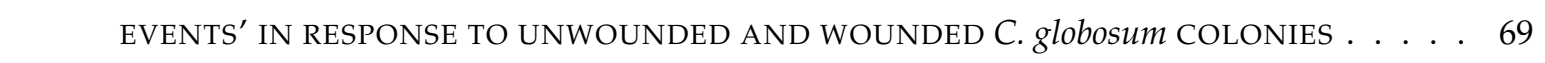


A.2.14CONTACT PHASE: KAPLAN MEIER CURVES FOR F. candida, H. nitidus, AND S. curviseta 'LATENCY TO THE FIRST COLONY CONTACT' IN RESPONSE TO UNWOUNDED AND WOUNDED C. globosum COLONIES . . . . . . . . . . . . . . . . . . . . . . . 69

A.2.15CONTACT PHASE: KAPLAN MEIER CURVES FOR F. candida, H. nitidus, AND S. curviseta 'LATENCY TO THE FIRST FEEDING EVENT' IN RESPONSE TO UNWOUNDED AND WOUNDED

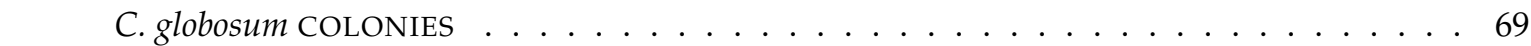

A.2.16CONTACT PHASE: KAPLAN MEIER CURVES FOR F. candida, H. nitidus, AND S. curviseta 'FEEDING ONSET LATENCY AFTER THE FIRST COLONY CONTACT' IN RESPONSE TO UNWOUNDED AND WOUNDED C. globosum COLONIES . . . . . . . . . . . . . . 70

$3.1 \quad$ LAYOUT AND DIMENSIONS OF THE EXPERIMENTAL ARENA $\ldots \ldots \ldots \ldots$

3.2 RESPONSE OF ISOPODS TO FUNGAL COLONIES. ARRIVAL TENDENCIES (VARIABLE: 'LATENCY TO THE FIRST ARRIVAL AT THE CENTRAL ZONE') AND 'PERCENTAGE OF TIME IN CENTRAL ZONES' OF O. asellus IN THE PRESENCE OF UNWOUNDED AND WOUNDED

C. globosum COLONIES AND FUNGAL-FREE CONTROLS _ . . . . . . . . . . . . . . . 79

3.3 O. asellus ARRIVAL TENDENCIES (VARIABLE: 'LATENCY TO THE FIRST ARRIVAL AT THE

CENTRAL ZONE') AND 'PERCENTAGE OF TIME IN THE CENTRAL ZONE' IN RESPONSE TO

3-OCTANONE, 3-METHYL-1-BUTANOL, AND PARAFFIN CONTROLS . . . . . . . . . . 80

$4.1 \quad$ DIMENSIONS OF THE EXPERIMENTAL ARENA $\ldots \ldots \ldots$. . . . . . . . . . . . . . . . 102

4.2 KAPLAN MEIER CURVES OF F. candida 'FIRST ARRIVAL AT THE CENTRAL ZONE' IN RE-

SPONSE TO FUNGAL COLONIES AND MEA CONTROLS . . . . . . . . . . . . . . . . . . 109

4.3 F. candida 'RESIDENCE TIME IN THE CENTRAL ZONE' AND 'MEAN DURATION OF CEN-

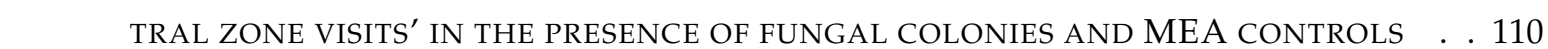

4.4 F. candida 'RESIDENCE TIME IN THE CENTRAL ZONE' AND KAPLAN MEIER CURVES FOR THE 'FIRST ARRIVAL AT THE CENTRAL ZONE' IN RESPONSE TO FUNGAL LIFE FORMS ․ . 111

4.5 KAPLAN MEIER CURVES FOR F. candida 'FIRST ARRIVAL AT THE CENTRAL ZONE' IN RESPONSE TO UNWOUNDED AND WOUNDED COLONIES OF FILAMENTOUS FUNGI . . . . . 113

4.6 F. candida 'RESIDENCE TIME IN THE CENTRAL ZONE' AND KAPLAN MEIER CURVES FOR THE 'FIRST ARRIVAL AT THE CENTRAL ZONE' IN RESPONSE TO THE P. expansum CHAR-

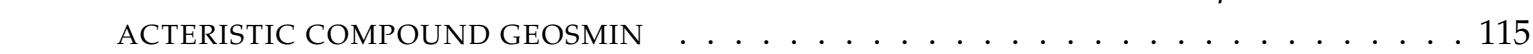

4.7 'DISTRIBUTION OF RESIDENCE TIME' OVER PREDEFINED ZONES IN RESPONSE TO THE P. expansum CHARACTERISTIC COMPOUND GEOSMIN . . . . . . . . . . . . . . 115

4.8 CONTACT PHASE: KAPLAN MEIER CURVES FOR F. candida 'LATENCY TO THE FIRST COLONY CONTACT' ${ }^{\prime}$ AND 'LATENCY TO THE FIRST FEEDING EVENT' IN RESPONSE TO COLONIES OF FILAMENTOUS FUNGI, YEASTS, AND MEA CONTROLS $\ldots$. . . . . . . 118 4.9 CONTACT PHASE: 'CONTACT TIME' OF F. candida IN RESPONSE TO COLONIES OF FILAMENTOUS FUNGI, YEASTS, AND MEA CONTROLS . . . . . . . . . . . . . . . 118 4.10 CONTACT PHASE: KAPLAN MEIER CURVES FOR F. candida' LATENCY TO THE FIRST CONTACT' ${ }^{\prime}$ AND 'LATENCY TO THE FIRST FEEDING EVENT' IN RESPONSE TO FUNGAL LIFE FORMS . . . . . . . . . . . . . . . . . . . . . . . . . . . . . . . . . . 119 4.11 CONTACT PHASE: 'CONTACT TIME' OF F. candida IN RESPONSE TO FUNGAL LIFE FORMS. 120 4.12 CORRELATION BETWEEN $F$. candida REPRODUCTION (NUMBER OF EGGS) AND GROWTH

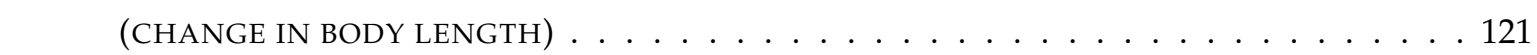
4.13 F. candida REPRODUCTION AND GROWTH IN RESPONSE TO FUNGAL DIETS . . . . . . . . 122 A.4.1 CALIBRATION PLOT FOR THE AUTHENTIC VOLATILE COMPOUND GEOSMIN . . . . . . . 134 


\section{LIST OF TABLES}

1.1 OVERVIEW OF VOLATILE-MEDIATED INTERACTIONS BETWEEN FUNGI AND INVERTE-

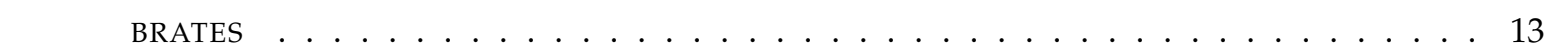

2.1 SUBJECT OF THE PRESENT STUDY AND OVERVIEW ON COMPONENTS OF THE FOOD SE-

LECTION PROCESS (ADAPTED FROM Dethier et al. (1960), Schoonhoven et al. (2005))] . . 39

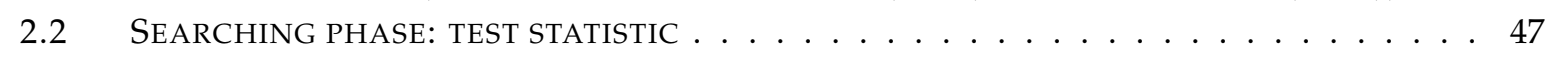

2.3 CONTACT PHASE: WILCOXON-MANN-WHITNEY TEST STATISTIC . . . . . . . . . . . . . 49

2.4 CONTACT PHASE: COX REGRESSION TEST STATISTIC FOR TIME DEPENDENT EVENT DATA 49

A.2.1 ANALYTICAL RESPONSE TO AUTHENTIC COMPOUNDS 3-OCTANONE, 3-OCTYL ACETATE,

AND 3-METHYL-1-BUTANOL (CONCENTRATION SERIES) . . . . . . . . . . . . . . 62

A.2.2 PRESENCE AND ABSENCE OF VOLATILE COMPOUNDS IDENTIFIED FROM HEADSPACE

\begin{tabular}{|l}
\hline SAMPLES OF UNWOUNDED AND WOUNDED C. globosum COLONIES AND FUNGAL-FREE \\
\hline \hline MEA CONTROLS $\ldots \ldots \ldots \ldots \ldots \ldots \ldots \ldots \ldots \ldots \ldots \ldots \ldots \ldots \ldots \ldots \ldots \ldots \ldots \ldots \ldots$
\end{tabular}

3.1 COX REGRESSION PAIRWISE COMPARISONS OF 3-OCTANONE AND 3-METHYL-1-BUTANOL

TREATMENT GROUPS AGAINST THE CONTROL GROUP WITH RESPECT TO THE 'LATENCY

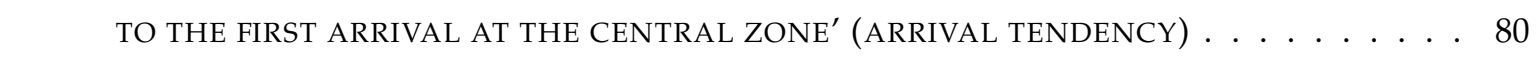

$4.1 \quad$ FUNGAL SPECIES AND GENOTYPES USED IN EXPERIMENTS. . . . . . . . . . . . . . . . . . 94

4.2 SUBJECT OF THE PRESENT STUDY AND OVERVIEW ON COMPONENTS OF THE FOOD SELECTION PROCESS (ADAPTED FROM Dethier et al. [1960), Schoonhoven et al. [2005) AND

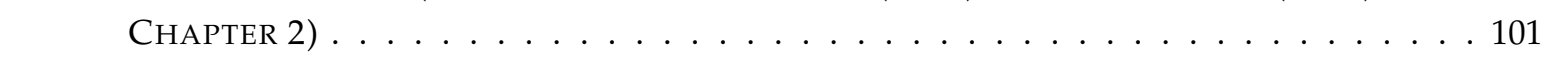

4.3 OVERVIEW OF WOUND-ACTIVATED VOLATILE COMPOUNDS $\ldots \ldots \ldots$. . . . . . . . . . . 107

4.4 SEARCHING PHASE: COX REGRESSION TEST STATISTIC FOR TIME-DEPENDENT BEHAVIOURAL

\begin{tabular}{|l|}
\hline VARIABLES 'LATENCY TO THE FIRST ARRIVAL' (ARRIVAL TENDENCY) AND 'DURATION \\
\hline OF THE FIRST CENTRAL ZONE VISIT' (DEPARTURE TENDENCY) IN RESPONSE TO FUNGAL \\
\hline
\end{tabular}

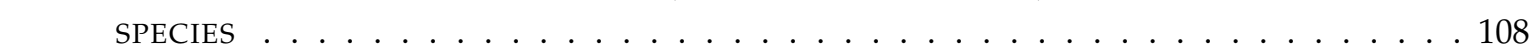

4.5 SEARCHING PHASE: TEST STATISTIC OF PAIRWISE COMPARISONS USING DUNN'S TEST

WITH RESPECT TO THE 'RESIDENCE TIME IN THE CENTRAL ZONE' AND THE 'MEAN DU-

RATION OF CENTRAL ZONE VISITS' IN RESPONSE TO FUNGAL SPECIES . . . . . . . . . 109

4.6 SEARCHING PHASE: TEST STATISTIC FOR 'LATENCY TO THE FIRST ARRIVAL AT THE CEN-

\begin{tabular}{|l|}
\hline TRAL ZONE' (ARRIVAL TENDENCY), 'DURATION OF THE FIRST CENTRAL ZONE VISIT' $^{\prime}$ \\
\hline \hline (DEPARTURE TENDENCY), 'RESIDENCE TIME IN THE CENTRAL ZONE', AND 'MEAN DU-
\end{tabular}

RATION OF CENTRAL ZONE VISITS' IN RESPONSE TO FUNGAL LIFE FORMS . . . . . . . . 111

4.7 SEARCHING PHASE: TEST STATISTIC FOR 'LATENCY TO THE FIRST ARRIVAL AT THE CEN-

TRAL ZONE' (ARRIVAL TENDENCY), 'DURATION OF THE FIRST CENTRAL ZONE VISIT'

(DEPARTURE TENDENCY), 'RESIDENCE TIME IN THE CENTRAL ZONE', AND 'MEAN DU-

RATION OF CENTRAL ZONE VISITS', AND THE 'DISTRIBUTION OF THE RESIDENCE TIME'

OVER ZONES IN RESPONSE TO UNWOUNDED AND WOUNDED FUNGAL COLONIES (POOLED

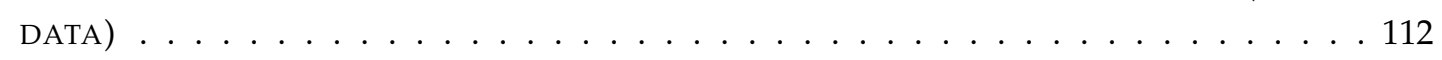


4.8 SEARCHING PHASE: TEST STATISTIC FOR'LATENCY TO THE FIRST ARRIVAL AT THE CENTRAL ZONE' (ARRIVAL TENDENCY), 'DURATION OF THE FIRST CENTRAL ZONE VISIT' (DEPARTURE TENDENCY), 'RESIDENCE TIME IN THE CENTRAL ZONE', 'MEAN DURATION OF CENTRAL ZONE VISITS', AND THE 'DISTRIBUTION OF THE RESIDENCE TIME'

OVER THE ZONES IN RESPONSE TO UNWOUNDED AND WOUNDED FUNGAL COLONIES OF FILAMENTOUS FUNGI (SEPARATE ANALYSIS PER FUNGAL SPECIES) $\ldots$. . . . . . . . 112

4.9 SEARCHING PHASE: TEST STATISTIC FOR 'LATENCY TO THE FIRST ARRIVAL AT THE CEN-

TRAL ZONE' (ARRIVAL TENDENCY), 'DURATION OF THE FIRST CENTRAL ZONE VISIT'

(DEPARTURE TENDENCY) IN RESPONSE TO GEOSMIN $\ldots \ldots \ldots \ldots$. . . . . . . . . . . 114

4.10 SEARCHING PHASE: TEST STATISTIC OF PAIRWISE COMPARISONS USING DUNN'S TEST WITH RESPECT TO THE 'RESIDENCE TIME IN THE CENTRAL ZONE' IN RESPONSE TO

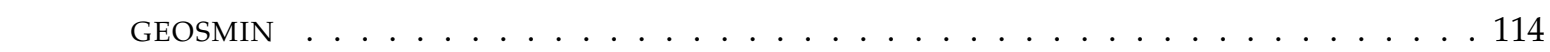

4.11 CONTACT PHASE: COX REGRESSION TEST STATISTIC FOR THE TIME-DEPENDENT VARI-

ABLES 'LATENCY TO THE FIRST CONTACT' (CONTACT TENDENCY), 'DURATION OF THE

FIRST CONTACT' ${ }^{\prime}$ (DEPARTURE TENDENCY), AND 'LATENCY TO THE FIRST FEEDING EVENT'

IN RESPONSE TO FUNGAL SPECIES . . . . . . . . . . . . . . . . . . . . . . . 117

4.12 CONTACT PHASE: TEST STATISTIC OF PAIRWISE COMPARISONS USING DUNN'S TEST

WITH RESPECT TO THE 'CONTACT TIME' IN RESPONSE TO FUNGAL SPECIES . . . . . . . 117

4.13 CONTACT PHASE: TEST STATISTIC FOR 'LATENCY TO THE FIRST CONTACT' ${ }^{\prime}$ (CONTACT

TENDENCY), 'DURATION OF THE FIRST CONTACT' (DEPARTURE TENDENCY), 'LATENCY

TO THE FIRST FEEDING EVENT' (FEEDING TENDENCY), AND 'CONTACT TIME' IN RE-

SPONSE TO FUNGAL LIFE FORMS (YEASTS AND FILAMENTOUS FUNGI; POOLED DATA) . . 119

4.14 CONTACT PHASE: TEST STATISTIC FOR VARIABLES 'LATENCY TO THE FIRST CONTACT'

(CONTACT TENDENCY), 'DURATION OF THE FIRST CONTACT' (DEPARTURE TENDENCY),

'LATENCY TO THE FIRST FEEDING EVENT' (FEEDING TENDENCY), AND 'CONTACT TIME'

IN RESPONSE TO UNWOUNDED AND WOUNDED FUNGAL COLONIES (POOLED DATA) . . 120

4.15 COLLEMBOLA FITNESS: TEST STATISTIC FOR PARAMETERS ${ }^{\prime}$ REPRODUCTION $^{\prime}$ AND $^{\prime}$ GROWTH $^{\prime}$

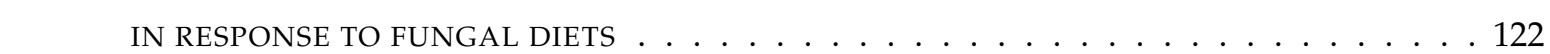

A.4.1 ANALYTICAL RESPONSE TO AUTHENTIC GEOSMIN (CONCENTRATION SERIES) . . . . . . 134

A.4.2 PRESENCE AND ABSENCE OF VOLATILE COMPOUNDS IDENTIFIED FROM HEADSPACE SAMPLES OF C. terricola, $M$. pulcherrima, T. dulcitum YEAST COLONIES, VEGETATIVE AND SPORULATING, UNWOUNDED AND WOUNDED COLONIES OF FILAMENTOUS FUNGI $A$. nidu-

lans, T. harzianum, P. expansum, AND FUNGAL-FREE MEA MEDIUM CONTROLS . . . . . . 135

A.4.3 WILCOXON TEST STATISTIC - EFFECT OF FUNGAL TISSUE WOUNDING ON QUANTITIES

OF VOLATILE COMPOUNDS . . . . . . . . . . . . . . . . . . . . . . 140

A.4.4 ON-PATCH CONTACT BEHAVIOUR RAW DATA ON THE 'DURATION OF THE FIRST FEED-

ING EVENT', 'TOTAL FEEDING TIME', AND 'PATCH CONTACT FREQUENCY PRIOR FEEDING'145 


\section{SUMMARY}

Fungi are considered as main decomposers in terrestrial ecosystems and, due to their diverse lifestyles, engaged in a plethora of interactions with soil invertebrates. Determining the underlying mechanisms that regulate interactions with invertebrates is of major importance for understanding the dynamics of soil fungal and animal communities and assessing the impact of these interactions on ecosystem processes and functions. The outcome of invertebrate-fungus interactions has been assumed to depend strongly on fungal chemical properties, viz. the production of non-volatile and volatile secondary metabolites. Soil invertebrates are known to use fungal-derived volatiles as cues for the location of suitable habitats, feeding, and oviposition sites. However, especially with regard to springtails (Collembola) and woodlice (Isopoda), a direct link between the dynamics in fungal volatile emissions and the behaviours underlying food location and selection of these important decomposers is still missing. The aim of the present $\mathrm{PhD}$ project was to investigate this aspect in more detail by combining analyses of fungal volatile profiles and behavioural responses of animals by continuous video observation and by focussing on different behavioural components of the food selection process separately.

The first main intent was to find out whether a certain group of volatiles, namely oxylipins, are used as cues by isopods and Collembola during foraging. Derived from the fact that the constitutive and wound-activated emission is a conserved mechanism in higher fungi I assume that oxylipin volatiles are ubiquitous in soil habitats. Since oxylipin volatiles are well known to play significant roles as infochemicals in plant-insect interactions I hypothesised that oxylipin volatiles are of similar importance in mediating interactions between fungi and soil invertebrates and function as food-finding cues for Collembola (F. candida, S. curviseta, H. nitidus) and isopods (O. asellus). Unexpectedly, wound-activated increases in oxylipin emissions did not increase the food-finding efficiency of these animals, however, independent of the wounding treatment, isopods were found to be attracted to C. globosum fungal colonies. Moreover, the common fungal oxylipin volatile 3-octanone arrested isopods in close proximity to the volatile source. This provides very first evidence of a role of fungal volatiles in affecting the foraging behaviour of isopods and indicates that isopods use volatiles as information to locate fungal food from a distance. Furthermore, upon direct contact with fungal colonies, fungal tissue wounding increased the acceptance of C. globosum colonies as food source by Collembola and, most interestingly, the mere presence of 
3-octanone elicited test-biting behaviour in these animals, a here newly-observed component of the Collembola foraging behaviour. These findings strongly suggest that oxylipin volatiles, at least 3-octanone, in fact influence the foraging behaviour of both Collembola and isopods by acting as attractants, arrestants, and phagostimulants.

The second main intent was to investigate whether Collembola (F. candida) are able to differentiate between fungi of varying suitability by means of volatiles. Therefore, I observed behavioural responses of Collembola to different yeasts and filamentous fungi, determined fitness consequences of the respective fungal diets, and analysed fungal volatile profiles. In line with expectations, volatile-mediated responses of Collembola were largely reflected in the acceptance of fungi as food source and finally in the fitness of the animals (growth and reproduction), indicating that the use of volatile cues is important for Collembola to optimise their fitness. The observed higher attractivity and acceptance of yeasts and the filamentous fungus A. nidulans can most likely be attributed to the presence of 3-methyl1-butanol within an otherwise volatile-poor background. Interestingly, Collembola were deterred by the volatile bouquet of the filamentous fungus P. expansum, did not accept this fungus as food source and had the lowest fitness increase. Responses to the Penicillium characteristic terpenoid geosmin indicate that this compound may contribute to the repellent effect. Possibly, some fungi produce such repellent compounds to fend off predators. These results clearly show that Collembola discriminatingly use fungal-derived volatile cues to make adaptive foraging decisions. Besides chemical properties, differences in physical properties (unicellular or hyphal growth) may influence the accessibility and consequently the acceptance of fungal food sources by Collembola, however, this needs to be tested in future studies.

Overall, this thesis provides further evidence of a significant role of fungal chemical properties, volatiles in particular, in influencing the outcome of fungus-invertebrate interactions. Future studies should focus on investigating whether the here observed behavioural responses of isopods and Collembola actually reflect responses exhibited in their natural habitat. 


\section{CHAPTER}

\section{A REVIEW OF THE ROLE OF FUNGAL VOLATILES AS INFOCHEMICALS IN INVERTEBRATE-FUNGUS INTERACTIONS}

\subsection{INTRODUCTION}

Fungal and animal communities are interconnected via a multitude of interspecific interactions. Fungi are important mutualists, prey, predators and competitors of enormously species rich invertebrate communities, comprising insects, mites, isopods, nematodes, and molluscs (Figure 1.1). Therefore, obtaining a better understanding of the factors regulating interactions with invertebrates is crucial for predicting the composition of fungal communities and the involvement of these inherently dynamic interaction processes in ecosystem functioning (Crowther et al. 2012; 2011a b; 2013).

Like in plant-animal interactions (Schoonhoven et al. 2005), the establishment of short- or long-term intimate fungus-invertebrate contacts as well as the disintegration of such contacts are likely driven by fungal chemistry (Gloer 1995, Rohlfs 2015). The 'decision' of invertebrates to pick up, feed on or avoid a fungus may thus be based on the perception and neurophysiological integration of fungus-borne chemical information. Compared to plantanimal interactions, however, we have only fragmentary knowledge about the role of such fungal infochemicals in regulating interactions with invertebrates.

Because of their physicochemical properties infochemicals can be roughly classified as nonvolatile and volatile compounds. Those fungal metabolites that tend to vaporize easily, i.e. to transit from liquid to gas phase in a temperature range in which invertebrates are active, have the potential to act as infochemicals. The so far $\sim 250$ identified fungal volatile metabolites (Morath et al.2012) originate from different biosynthetic pathways based on amino acid, fatty acid or mevalonate precursors (Korpi et al.2009). Therefore, fungi often emit complex mixtures of volatiles comprising alcohols, organic acids, alkenes, aldehydes, acetates, sulphides, and terpenoid compounds. Invertebrates, in particular insects, have evolved a high 
diversity of receptors to perceive many of these metabolites (Münch and Galizia 2016). Fungal volatile metabolites may thus 'inform' invertebrates about the presence and properties of fungi without direct contact and trigger fitness-relevant decision-making, e.g. optimal foraging and mutualist choice, avoidance of fungal pathogens, etc.

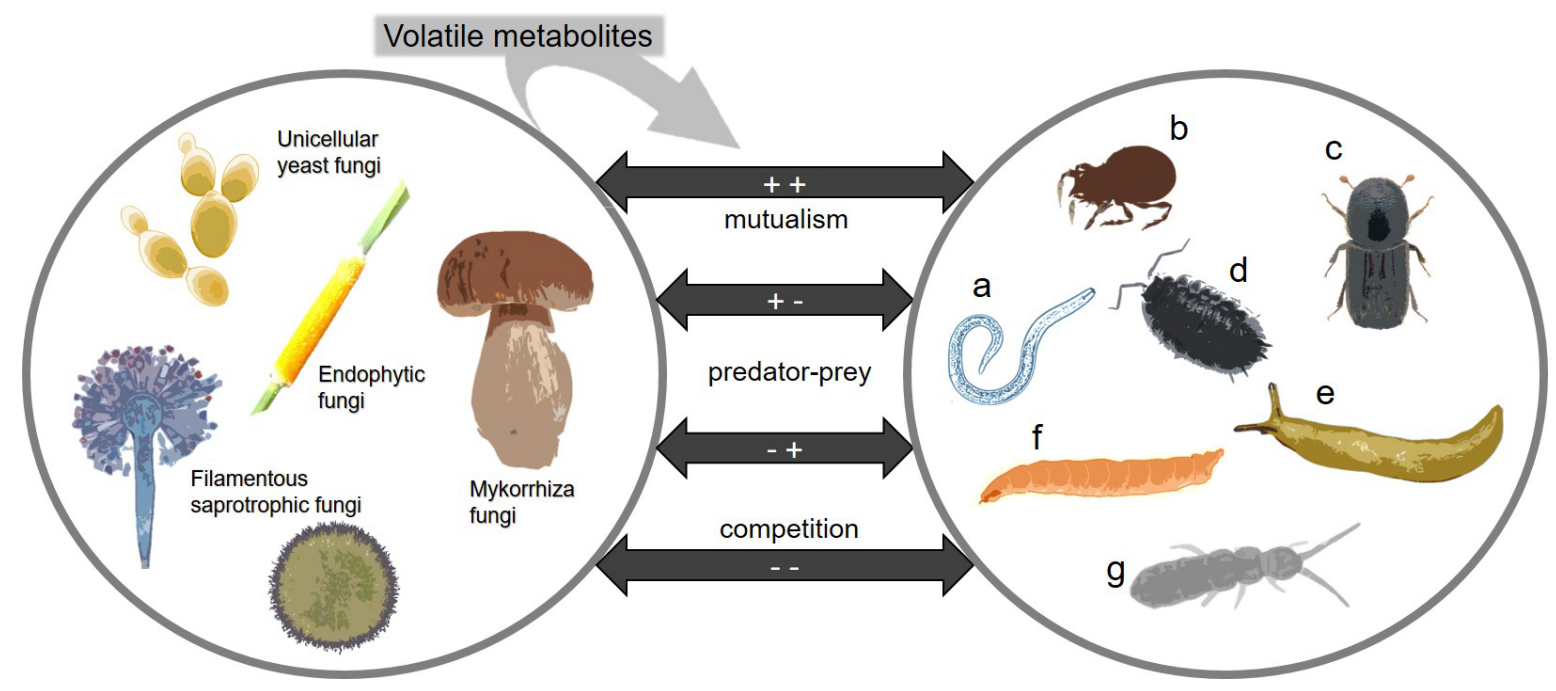

Figure 1.1: Interaction types categorised by the effect potentially mediated by volatile metabolites. (a) nematode, (b) mite, (c) beetle, (d) isopod, (e) mollusc, (f) fruit fly larva, (g) springtail.

The aim of this review is to compile and critically evaluate the current evidence of fungal volatile metabolites as infochemicals for invertebrates. The focus is mainly on bipartite invertebrate-fungus interactions; however, I also elaborate on the potential role of fungal volatiles as infochemicals in regulating the strength of multispecies interactions.

\subsection{FUNGI AS DIET}

Several studies have demonstrated that fungal-derived volatiles and/or fungal authentic compounds affect the foraging behaviour of fungivorous springtails, beetles, flies, woodlice, earthworms, mites, and slugs (Table 1.1). Springtails (Collembola) and mites (Acari) are assumed to use olfactory cues in the recognition and discrimination of fungal food sources (Bengtsson et al. 1988; 1991, Brückner et al. 2018, Hedlund et al. 1995, Sadaka-Laulan et al. 1998, Staaden et al. 2011, Vanhaelen et al. 1980). Bengtsson et al. (1991) have demonstrated that springtails are able to adjust their behaviour in the presence of different fungal authentic volatile compounds (Table 1.1), indicating behavioural plasticity. In olfactometer 
experiments groups of euedaphic (soil living) springtails (Onichiurus spp.) were attracted to a number of different fungal species, however, the degree of attraction varied between fungal species and in relation to species- and substrate-specific qualitative and quantitative differences in volatile profiles (Bengtsson et al. 1988; 1991, Sadaka-Laulan et al. 1998). Here it is important to mention that, in general, when testing groups instead of individual animals it remains unclear if behavioural responses are affected by fungal-derived volatiles or additionally influenced by the odour of conspecifics. Sensory detection of and volatilemediated responses to fungi also differ between springtail species as it has been shown for sympatric $O$. cincta and $T$. flavescens and it is suggested that these differences contribute to differences in food selection by springtails (Hedlund et al. 1995). According to the mixed diet hypothesis springtails benefit from using different food sources for covering nutritional requirements and are considered as food generalists (e.g. Scheu and Simmerling 2004). Although there are species-specific preferences for certain fungi, the finding that springtails are attracted to a wide range of fungi and to rather common widespread authentic volatile compounds (e.g. CO2, alcohols) (Table 1.1) (Bengtsson et al.1991) supports this hypothesis. A more detailed observation of individual springtails by continuous video observation revealed that $F$. candida springtails are able to adjust their behaviour in the presence of food by switching from random non-directed to directed movement towards a non-fungal volatile source, but only from short distance $(2.5 \mathrm{~cm}$ ) (Auclerc et al. 2010). In contrast to the shortdistance response of $F$. candida it has been shown that $O$. armatus springtails were attracted from larger distances $(40 \mathrm{~cm})$ to a fungal food source and that movement and dispersal was even more strongly affected by fungal volatiles than by population density (Bengtsson et al. 1994). Sawahata et al. (2008) have demonstrated that aggregation of springtails on the palatable basidiomycete T. matsutake was weaker compared to other fungi and caused by a repellent effect of the fungal volatiles 1-octen-3-ol and methyl cinnamate, suggesting a role of volatiles in the direct defense of fungi against fungivory. Furthermore, volatile-mediated avoidance of certain fungi is assumed to be associated with fungal toxicity (Sadaka-Laulan et al. 1998) and was explicitly investigated by Staaden et al. (2011) who have shown that F. candida, H. nitidus, and S. furcifera springtails preferred a mutant strain of the ascomycete A. nidulans, deficient in the production of secondary metabolites including the toxic compound sterigmatocystin, over a sterigmatocystin producing wild type strain. This finding strongly suggests that springtails are able to detect and avoid unpalatable toxic fungi from a distance by employing fungal-derived volatiles. However, discrepancies between volatilemediated attraction and acceptance of a fungus as food resource (Sadaka-Laulan et al. 1998) 
indicate that springtails use additional cues for the evaluation after arrival at a potential fungal food source. The additional use of other cues during the contact phase was also suggested to be relevant for successful foraging of O. asellus woodlice (Isopoda) as the observed preference for mouldy food was only significant after physical contact to a potential food source which indicates that olfactory cues could not be detected or do not play a role during the non-contact searching phase (Zidar et al. 2003). In contrast to O. asellus, P. scaber woodlice were attracted to litter and alpha-cellulose inoculated with microorganisms (undefined) and are assumed to employ volatiles which derive from the microbial breakdown of cellulose for the location of suitable feeding sites (Zimmer et al.1996). As it has been shown for example for the characteristic mushroom volatile 1-octen-3-ol, fungivorous animals can respond very differently to the same volatile compound. Whereas Proisotoma minuta springtails, M. halterata flies, and A. columbianus slugs were repelled/deterred by 1-octen-3-ol (Pfeil and Mumma 1993, Sawahata et al. 2008, Wood et al. 2001) it arrested O. armatus springtails (Bengtsson et al.1991), and attracted fungivorous C. moschata beetles (Tabata et al.2011) and Scheloribates mites (Brückner et al. 2018). This indicates that the perception and processing of fungal olfactory signals could have specifically evolved in fungus-invertebrate interactions depending on the characteristics of invertebrate nutritional requirements and fungal chemistry.

From the studies described above it can be assumed that, at least, for some soil-living fungivorous arthropods (springtails, woodlice) fungal-derived olfactory cues act as semiochemicals under laboratory conditions, however, one important question arises: Do fungal volatiles also influence the foraging behaviour of invertebrates under more natural conditions with consideration of the complex obstacle-rich structure of soil systems? Taking this aspect into account, Zirbes et al. (2011) investigated the foraging behaviour of E. fetida (Annelida) in response to volatiles from filtrates and authentic compounds of the ascomycete G. candidum under semi-natural conditions by using below-ground olfactometers filled with moist compost soil. Groups of earthworms were attracted to fungal volatiles horizontally as well as vertically up to a distance of $105 \mathrm{~cm}$, indicating that fungal volatiles, in fact, can act as infochemicals from a significant distance despite the obstacle-rich structure of a soil environment (Zirbes et al.2011). 


\subsection{FUNGI AS HOSTS}

Living together with host fungi brings a twofold advantage; fungal fruiting bodies provide a permanent food resource and additionally serve as shelter for both larvae and adults whereby foraging costs are eliminated. In turn, some arthropods are suggested to act as vectors of fungal spores or gametes and specific fungal volatile compounds are assumed to have evolved into 'pollinator'-attracting signals (Cloonan et al.2016a, Schiestl et al.2006. Steinebrunner et al.|2008a).

Xylobiont (bracket fungi) and deadwood inhabiting fungi form microhabitats that provide optimal living conditions for associated animals. Many beetle species, in particular bark beetles, are known to use fungi as hosts and often have species-specific symbiotic relationships with their fungal associates (Vega and Blackwell|2005). Guevara et al. (2000a b) have demonstrated that specialist ciid beetles use fungal species-specific volatile cues to discriminate between host and non-host fungi and, moreover, that the use of age-related characteristics in the volatile bouquet of the host fungus (C. versicolor) provides a mechanism for resource partitioning by O. glabriculus and C. boleti, both strongly associated with this fungus. In line with this, the specialist fungivorous beetle species $B$. reticulatus also relies on age-specific characteristics in volatile bouquets of their xylobiont host fungus, in particular the presence of the ubiquitous eight-carbon oxylipin volatile 3-octanone, to differentiate between young and fresh fruiting bodies and the preferred partially dead successional stage of this fungus (Holighaus et al. 2014). 3-octanone and other oxylipin volatiles, e.g. 1-octen-3-ol, 3-octanol, and 1-octanol, have been demonstrated to attract different bark beetle as well as some grain beetle species, suggesting that volatile oxylipins play an important role as infochemicals and key attraction factors in the host selection behaviour (Drilling and Dettner 2009, Fäldt et al. 1999. Pierce et al. 1991, Thakeow et al. 2008). Besides beetles, saproxylic bed bugs (A. obtectus) and wood wasps (S. noctilio) have been demonstrated to use fungal volatile cues for the location of their host fungi (Koban et al. 2016, Sarvary et al. 2016).

Volatiles also play a significant role in the strong mutualistic interaction between endophytically living Epichloë fungi and Botanophila flies that use different Epichloë species for feeding and oviposition and in return act as gamete vectors. Field bioassays by Schiestl et al. (2006) and Steinebrunner et al. (2008b) revealed that Epichloë characteristic volatile compounds, namely Chokol K and methyl (Z)-3-methyldodec-2-enoate, function as key attractants specifically for female Botanophila flies and direct them to the fungal stomata. Interestingly, Chokol $\mathrm{K}$ additionally inhibits the growth of mycoparasites and plant pathogenic 
fungi and it is suggested that the function of this compound as Botanophila attractant has evolved from its original function as fungal defense (Steinebrunner et al.|2008a).

\subsection{FUNGAL NICHE CONSTRUCTION}

Some fungi act as niche constructors by degrading and modifying plant substrates like deadwood and fruits and create suitable microhabitats for subsequent insect colonisers. On the one hand, in respective systems, interactions between insects and fungi often have a mutualistic character; whereas fungi are used as food source and provide optimal conditions for insect larval development, insects often benefit fungi by vectoring fungal spores or cells to new substrates (e.g. Ganter 1988, Gilbert|1980, Madden et al.|2018, Starmer et al. 1988). In this way insects can strongly affect the density and diversity of the fungal community and simultaneously benefit themselves by establishing their own niches (Buser et al. 2014, Stamps et al. 2012). Volatiles that were frequently demonstrated to act as attractants are mainly ubiquitous compounds - alcohols, acids, acetates, and aldehydes - produced by fungi during fermentation of sugar rich substrates (Table 1.1). The significance of fungal volatile cues in mediating attraction to fungal-colonised plant substrates was demonstrated with respect to fruit flies, moths, and beetles.

Although Drosophila fruit flies are well known to rely on fungal volatile cues for the longdistance location of fungal-colonised fruit substrates that serve as food and oviposition sites (Becher et al. 2010; 2012), a study by Palanca et al. (2013) suggests that the Drosophila-yeast mutualism may have evolved independently of fermentation since adult flies were attracted to both weakly or non-fermenting yeast species and fermenting species. Different Drosophila species exhibit volatile-mediated preferences for different yeasts (Buser et al.|2014, Dobzhansky et al. 1956, Scheidler et al. 2015) that are reflected in fitness benefits for both the fruit flies and the yeasts (Buser et al. 2014). Scheidler et al. (2015) have demonstrated that yeast species-specific behavioural responses of D. melanogaster and D. suzukii correlated with olfactory responses (electroantennography), indicating that these insects are able to detect species-specific chemical characteristics in yeast volatile profiles. This suggests a strong coadaptation between certain Drosophila and yeasts species (Scheidler et al. 2015) which is encouraged by volatile signalling.

Similar to fruit flies, adult grapevine-, apple-, and codling moths (L. botrana, E. postvittana, C. pomonella) use yeast-derived volatile cues for the long-distance location of yeast-colonised 
fermented fruit substrates that are used as food and oviposition sites (Tasin et al. 2011. Witzgall et al. 2012). It is assumed that the presence of mutualist and antagonist fungi affects the quality of the host plant as larval food. Contrary to the preference-performance hypothesis, oviposition choices made by adult moths were less reflected in the survival of their offspring. While E. postvittana and L. botrana larvae benefited from the presence of the grey mould fungus B. cinerea and were attracted by volatiles of this fungus (Mondy et al. 1998, Rizvi et al. 2016), adult female moths were repelled and avoided oviposition on B. cinereainfected berries (Tasin et al. 2011; 2012). Rizvi et al. (2016) suggested that the discrepancy between larval and adult behavioural responses may be due to differences in host requirements and/or feeding preferences.

Sap beetle species (Nitidulidae) prefer yeast-colonised fruit substrates as food source and oviposition site over uncolonised fruits (Blackmer and Phelan 1991, Nout and Bartelt|1998). It has been demonstrated that these beetles were attracted by different yeast species and blends of volatiles that were previously identified from attractive yeasts (Lin and Phelan 1991, Nout and Bartelt 1998, Phelan and Lin 1991). By means of subtractive and additive bioassays Lin and Phelan (1991) found out that attraction can mainly be assigned to certain volatile compounds - acetaldehyde, ethyl acetate, and 2-methylpropanol - single compounds, however, were less attractive than the respective three-compound blend (Table 1.1), indicating that the composition of yeast volatile profiles is more important for the detection of suitable microhabitats by sap beetles than the mere presence of single compounds. Moreover, Lin and Phelan (1992) have shown that sap beetles were attracted to volatiles derived from the insect-dependent yeast $C$. fagacearum but not to yeast species that are primarily dispersed by wind or water and concluded that the volatile bouquet of $C$. fagacearum is adapted for attracting sap beetles and/or other insect vectors. Similarly, different species of fungusgrowing ambrosia beetles were also demonstrated to rely on volatile cues for locating and selecting their respective fungal symbionts from a distance (Hulcr et al. 2011). These beetles create their own niche by vectoring fungal spores to dead wood substrates and actively cultivating the so-called 'fungal gardens'. The presence of morphological adaptations (mycangia) for the transport of fungal spores (Vega and Blackwell|2005) and the finding that the strongest attraction of ambrosia beetles is elicited by the volatile bouquets of their respective fungal mutualist partners (Hulcr et al. 2011) indicates strong coevolution and suggests that the use of volatile cues is important for the maintenance of close relationships between ambrosia beetles and their fungal symbionts. 


\subsection{FUNGi AS PATHOGENS \& PREDATORS}

Especially in eusocial insects, pathogen avoidance is of significant importance to prevent the spread of an infection through the whole nest via social interactions or infected cadavers of conspecifics that remain in the nest. Termites have different behavioural and physiological mechanisms to counter pathogen transmission (e.g. Rosengaus et al. 1998a: 1999: 1998b) and volatiles play a significant role in the detection of harmful microbes. Mburu et al. (2009) tested behavioural responses of termites to isolates of the pathogenic fungi M. anisopliae and B. bassiana of different virulence and found a positive correlation between isolate virulence and volatile-mediated repellency. Three compounds, namely 4,5-dihydro-5-pentyl-2(3H)furanone, 2-pyrrolidinone, and borneol, were identified to contribute most to the repellency and higher concentrations of these compounds are suggested to be responsible for the higher repellency of more virulent strains (Mburu et al. 2013; 2011). In line with this, Yanagawa et al. (2011; 2015) have demonstrated that termites increased their grooming activity in the presence of conspecifics infected with different pathogenic fungi without direct contact and furthermore, found a deterrent effect of the oxylipin volatile 3-octanone, which is emitted by the pathogenic fungus I. fumosorosea. Therefore, the use of fungal volatile cues by termites can be assumed to be of crucial importance for an early detection of pathogens and represents an effective prevention strategy. In contrast to the well investigated volatile-mediated pathogen avoidance behaviour of termites, this aspect is poorly explored with respect to other invertebrate groups. Besides termites, only the parasitoid wasp L. distinguendus and the pine weevil $H$. abietis are known to use fungal volatiles to avoid contact with fungal pathogens (Azeem et al. 2013, Steiner et al. 2007). Other studies that focused on pathogen avoidance behaviour of herbivorous termites, beetles, aphids, and parasitoid wasps also found a deterrent effect of different pathogenic fungi (e.g. Cotes et al. 2015. Hussain et al. 2010, Ormond et al. 2011, Rashki and Hirvani 2013), however, from these studies it remains unclear whether behavioural decisions solely based on volatile information and whether fungal-induced plant volatiles were responsible for behavioural decisions rather than fungal volatiles per se.

Another type of antagonism involves predacious fungi and nematodes. Nematophagous fungi A. oligospora and E. vermicola employ different volatiles for attracting their prey (Hsueh et al. 2017, Lin et al. 2013). In contrast to most of the above described functions of fungal volatiles as infochemicals, here, the emission of certain volatiles can be considered as a specific signalling pathway evolved to fulfil the function as nematode attractants. 


\subsection{FUNGi IN A MULTITROPHIC CONTEXT}

In multitrophic interactions fungal volatiles are used as cues by carnivorous and herbivorous predators as well as parasitoids during foraging to locate fungal-associated prey organisms. Preference tests by Hall and Hedlund (1999) and Pfeffer and Filser (2010) revealed that the predatory mite $H$. aculeifer was attracted by the volatile bouquet of two saprotrophic fungi but not by the volatile bouquet of its prey, fungivorous springtails. Both studies have also shown that previous grazing of fungal colonies by springtails did not increase attraction of $H$. aculeifer. The use of volatile cues that are typically emitted by prey-associated fungal food patches rather than the use of more specific cues originating from single prey species is suggested to be more efficient for generalist predators of fungivorous animals since it may increase the possibility to encounter more than one prey species (Pfeffer and Filser 2010). This also applies to parasitoid and predacious wasps, flies, and beetles (Table 1.1). A number of studies have demonstrated that parasitoid wasps take advantage of using volatile cues emitted by fungi that serve as hosts and/or niche constructors for the wasp's prey organisms, Drosophila fruit flies, beetles, and woodwasps (Boone et al. 2008, Dicke et al. 1984. Sullivan and Berisford 2004, Vet et al. 1984). Interestingly, females of the parasitoid wasp I. leucospoides are even able to use age-specific characteristics in the volatile profile of the fungal symbiont of their host $S$. noctilio for the location of suitably aged host larvae (Jofré et al.|2016).

\subsection{Conclusion}

Fungal volatiles play important roles as mediators of fungus-invertebrate interactions and fulfil multiple functions as attractants and deterrents; they are used as food-finding cue by foraging invertebrates, inform on the presence of suitable microhabitats (deadwood, fermented fruit substrates) for feeding and/or oviposition, mediate avoidance of fungal pathogens, are used as lure by predacious fungi to attract prey animals, and lead nonfungivorous parasitoids and predators to fungal-associated prey/host animals. The ubiquitous use of fungal volatiles as infochemicals by both above- and belowground invertebrates suggests a substantial involvement of volatiles in the maintenance of fungus-invertebrate interactions.

Two general patterns can be deduced from the here reviewed literature: first, insects that are 
naturally associated with microbe/fungal pre-colonised plant substrates (e.g. deadwood, fermented fruits) rely on common ubiquitous compounds related to microbial activity and often deriving from yeast fungal colonisers - short-chain alcohols, acids, acetates, aldehydes - rather than on more specific compounds like terpenoids. Some studies suggest an involvement of insects in vectoring fungal propagules to new substrates/environments in respective systems, however, the current evidence is rather weak. Potential mutualistic characters of respective interactions need to be investigated in further detail, e.g. by measuring insect-related dispersal efficiencies and fitness consequences for both insects and fungi. The second pattern that appears from the literature relates to a certain group of fungal volatiles, namely oxylipins (eight-carbon compounds). Especially for deadwood-associated beetles, eight-carbon oxylipin volatiles (3-octanone, 1-octen-3-ol, 1-octanol, 3-octanol, etc.) are important infochemicals and significantly involved in the location and selection of (mutualist) host fungi. Furthermore, a few studies demonstrate that oxylipin volatiles mediate avoidance of fungal pathogens in hymenoptera and coleoptera by acting as deterrents. Plantderived oxylipins are well known to play major roles as infochemicals in plant-herbivore systems, however, whether fungal-derived oxylipins are of equal importance in mediating fungus-invertebrate interactions, as it is suggested by Hanski (1989) and Holighaus and Rohlfs (2018) remains to be investigated in more detail by including other groups of fungusrelated invertebrates. 
Table 1.1: Overview of volatile-mediated interactions between fungi and invertebrates with focus on animal behavioural responses to fungal volatiles, sorted by type of interaction and animal groups. Studies with focus on subjects of applied chemistry without reference to natural ecology are not included. (n.r.: no response, n.p.: no preference)

\begin{tabular}{|c|c|c|c|c|c|}
\hline Animal Species & Group & $\begin{array}{l}\text { Odour Source } \\
\text { (fungal species, VOC, material infected with fungi) }\end{array}$ & Mode of Action, Behavioural response & Experimental Setup & Reference \\
\hline \multicolumn{6}{|c|}{ FUNGI AS DIET } \\
\hline Tyrophagus putrescentiae & Acari & $\begin{array}{l}\text { VOC identified from } 15 \text { Homobasidiomycetes: } \\
\text { Cis- \& trans-octa-1,5-dien-3-ol }\end{array}$ & Attraction & Olfactometer & Vanhaelen et al. (1980) \\
\hline $\begin{array}{l}\text { Archegozetes longisetosus } \\
\text { Scheloribates sp. }\end{array}$ & Acari & $\begin{array}{l}\text { Pairwise testing of: } \\
\text { (a) Mixture of essential amino acids } \\
\text { (b) Mixture of non-essential amino acids } \\
\text { (c) Mixture of fatty acids } \\
\text { (d) Mixture of D-glucose and 1-octen-3-ol }\end{array}$ & $\begin{array}{l}\text { A. longisetosus: Preference for (c) } \\
\text { Scheloribates sp.: Preference for (d) }\end{array}$ & $\begin{array}{l}\text { Circular two-choice olfactometer (petri dish); contact to the } \\
\text { volatile sources was probably possible } \\
\text { groups of } 10 \text { individuals tested per run }\end{array}$ & Brückner et al. (2018) \\
\hline Eisenia fetida & Annelida & $\begin{array}{l}\text { (a) VOC filtrate of Geotrichum candidum } \\
\text { VOCs identified from G. candidum: } \\
\text { (b) Ethyl acetate } \\
\text { (c) Ethyl propionate } \\
\text { (d) Ethyl penanoate } \\
\text { (e) Ethyl hexanoate } \\
\text { (f) 3-octanone } \\
\text { (g) 2-methyl-1-butanol } \\
\text { (h) 3-methyl-1-butanol } \\
\text { (i) 2-methyl-1-propanol }\end{array}$ & $\begin{array}{l}\text { (a) Attraction (horizontal \& vertical) } \\
\text { (b) n.r. } \\
\text { (c) n.r. } \\
\text { (d) Attraction (horizontal) }(1,10,100,1000 \mu l) \\
\text { (e) Attraction (horizontal) }(1,100,1000 \mu \text {; } 10 \mu l \text { : n.r.) } \\
\text { (f) n.r. } \\
\text { (g) n.r. } \\
\text { (h) n.r. } \\
\text { (i) n.r. }\end{array}$ & $\begin{array}{l}\text { Horizontal four-arm olfactometer (below-ground, filled with } \\
\text { compost soil); } \\
\text { groups of 5-150 individuals tested per run } \\
\text { Vertical olfactometer (below-ground, filled with compost soil); } \\
\text { groups of } 10 \text { individuals tested per run }\end{array}$ & Zirbes et al. (2011) \\
\hline Psyllobora vigintimaculata & Coleoptera & $\begin{array}{l}\text { (a) Plants infected with Podosphaera sp. vs. uninfected plants } \\
\text { vocs identified from Podosphaera sp.: } \\
\text { (b) 1-octen-3-ol } \\
\text { (c) 3-octanone } \\
\text { (d) 3-octanol } \\
\text { (e) Linalool } \\
\text { (f) Benzyl alcohol }\end{array}$ & $\begin{array}{l}\text { (a) Infected plants were preferred over uninfected plants } \\
\text { (b) } 1 \mu \mathrm{g} \text { : attraction; } 10 \mu \mathrm{g} \text { : attraction; } 100 \mu \mathrm{gg} \text { : attraction } \\
\text { (c) n.r. } \\
\text { (d) n.r. } \\
\text { (e) n.r. } \\
\text { (f) n.r. }\end{array}$ & $\begin{array}{l}\text { Two-arm olfactometer with active airflow; choice experiment; } \\
1 \text { individual tested per run }\end{array}$ & $\begin{array}{l}\text { Tabata et al. (2011) } \\
\end{array}$ \\
\hline Onychiurus armatus & Collembola & $\begin{array}{l}\text { (a) Verticililium bulbilosum grown on malt extract agar } \\
\text { (b) Verticillium bulbilosum grown on soil } \\
\text { (c) Penicillium spinolosum grown on malt extract agar } \\
\text { (d) Penicillium spinolosum grown on soil } \\
\text { (e) Mortierella isabellina grown on malt extract agar } \\
\text { (f) Mortierella isabellina grown on soil }\end{array}$ & $\begin{array}{l}\text { (a) V. bulbilosum preferred over control, attraction } \\
\text { (b) n.r. } \\
\text { (c) n.r. } \\
\text { (d) n.r. } \\
\text { (e) } n . r . \\
\text { (f) } M . \text { isabellina preferred over control, attraction }\end{array}$ & $\begin{array}{l}\text { Two-arm olfactometer with active airflow; } \\
\text { groups of } 7 \text { individuals tested per run; } \\
\text { treatments tested against control (malt extract agar, soil) }\end{array}$ & Bengtsson et al. (1988) \\
\hline Onychiurus armatus & Collembola & M. isabellina grown on soil & Attraction (from a distance of $40 \mathrm{~cm}$ ) & $\begin{array}{l}\text { One-arm olfactometer with } 5 \text { vials connected to each other \& } \\
\text { M. isabellina added to the farthest vial; } \\
\text { groups of } 60 \text { individuals tested per run; } \\
\text { direct contact to the odour source was possible }\end{array}$ & Bengtsson et al. (1994) \\
\hline
\end{tabular}

To be continued 
Table 1.1. Continuation

\begin{tabular}{|c|c|c|c|c|c|}
\hline $\begin{array}{l}\text { Orchesella cincta } \\
\text { Tomocerus flavescens }\end{array}$ & Collembola & $\begin{array}{l}\text { (a) Cladosporium herbarum } \\
\text { (b) Mortierella isabellina } \\
\text { (c) Cladosporium cladosporioides } \\
\text { (d) Penicillium spinulosum }\end{array}$ & $\begin{array}{l}\text { (a) Attraction (O. cincta) } \\
\text { (b) Attraction (T. flavescens) } \\
\text { (c) n.r. } \\
\text { (d) n.r. }\end{array}$ & Two-arm olfactometer with active airflow (1 individual) & Hedlund et al. (1995) \\
\hline Onychiurus sinensis & Collembola & $\begin{array}{l}\text { (a) Alternaria alternata } \\
\text { (b) Aureobasidium pullulans } \\
\text { (c) Cladosporium cladosporioides } \\
\text { (d) Epicoccum purpurascens } \\
\text { (e) Trichothecium roseum } \\
\text { (f) Mucor plumbeus } \\
\text { (g) Penicillium spinulosum } \\
\text { (h) Trichoderma polysporum }\end{array}$ & $\begin{array}{l}\text { Attractivity ranking treatment } 1 \text { : } \\
(\mathrm{f})>(\mathrm{e})>(\mathrm{a})>(\mathrm{b})=(\mathrm{g})>(\mathrm{c})=(\mathrm{d})>\text { (h) (repulsion) } \\
\text { Attractivity ranking treatment } 2 \text { : } \\
(\mathrm{e})=(\mathrm{c})=(\mathrm{f})=(\mathrm{d})>(\mathrm{b})>(\mathrm{a})=(\mathrm{g})=(\mathrm{h}) \\
\text { Treatment } 3 \text { : } \\
\text { Preference for/attraction to (e), (d), (g), (f) }\end{array}$ & $\begin{array}{l}\text { Circular two-choice olfactometer (petri dish) } \\
\text { groups of } 20 \text { individuals tested per run; } \\
\text { direct contact to the odour source was possible } \\
\text { Treatment 1: pure fungal tissue } \\
\text { Treatment 2: fungus + litter vs. control (litter) } \\
\text { Treatment 3: fungal odour solution vs. control (filter paper) }\end{array}$ & Sadaka-Laulan et al. (1998) \\
\hline $\begin{array}{l}\text { Proisotoma minuta } \\
\end{array}$ & Collembola & $\begin{array}{l}\text { VOCs identified from Tricholoma matsutake: } \\
\text { (a) 1-octen-3-ol } \\
\text { (b) Methyl cinnamate }\end{array}$ & $\begin{array}{l}\text { (a) Aggregation decreased with increasing concentration; } \\
\text { aggregation totally inhibited at } 1000 \text { ppm (repellence) } \\
\text { (b) } 0.001,0.01,0.1 \mathrm{ppm} \text { : no inhibition of aggregation; } \\
1,10,100 \mathrm{ppm} \text { : incomplete but significant inhibition } \\
1000 \mathrm{ppm} \text { : strong inhibition of aggregation (repellence) }\end{array}$ & Circular offactometer; groups of 70 individuals tested per run & Sawahata et al. (2008) \\
\hline $\begin{array}{l}\text { Folsomia candida } \\
\text { Folsomia candida } \\
\text { Heteromurus nitidus } \\
\text { Supraphorura furcifera }\end{array}$ & $\begin{array}{l}\text { Collembola } \\
\text { Collembola }\end{array}$ & $\begin{array}{l}\text { Intimate mix of cow dung debris \& feces } \\
\text { (a) Aspergillus nidulans (WT) vs. A. nidulans ( } \Delta \text { laeA) } \\
\text { (b) Cladosporium cladosporioides vs. A. nidulans (WT) } \\
\text { (c) A. nidulans (sterigmatocystin deficient) vs. A. nidulans (WT) } \\
\text { (d) Ungrazed A. nidulans (WT) vs. ungrazed } \\
\text { (e) Ungrazed Laccaria bicolor vs. ungrazed }\end{array}$ & $\begin{array}{l}\text { Attraction (from a distance of } 25 \mathrm{~mm} \text { ) } \\
\text { Collembola generally attracted to fungi } \\
\text { (a) A. nidulans ( } \Delta \text { laeA) preferred (all species) } \\
\text { (b) C. cladosporioides preferred (H. nitidus \& S. furcifera) } \\
\text { (c) C. cladosporioides preferred (H. nitidus \& S. furcifera) } \\
\text { (d) Ungrazed preferred (F. candida \& H. nititdus) } \\
\text { (e) Ungrazed preferred (F. candida \& H. nititidus) }\end{array}$ & $\begin{array}{l}\text { Video observation; } 1 \text { individual tested per run; no-choice } \\
\text { Four-chamber olfactometer; choice experiment; } \\
\text { groups of } 25 \text { individuals tested per run; } \\
\text { C. cladosporioides was tested as a 'high quality reference' }\end{array}$ & \begin{tabular}{|l|} 
Auclerc et al. (2010) \\
Staaden et al. (2011)
\end{tabular} \\
\hline & $\begin{array}{l}\text { Diptera } \\
\text { Dermaptera }\end{array}$ & $\begin{array}{l}\text { Blend of VoCs identified from Lysurus mokusin: } \\
\text { Butanoic acid + p-cresol + phenol + indole }\end{array}$ & $\begin{array}{l}\text { Flies: Attraction of Sacophagidae, Calliphoridae, Muscidae, } \\
\text { Sepsidae, Drosophilidae } \\
\text { Earwigs: n.r. }\end{array}$ & Field traps for catching flies and earwigs & Chen et al. (2014) \\
\hline Ariolimax columbianus & Gastropoda & $\begin{array}{l}\text { 1-octen-3-ol (identified from Clitophilus prunulus with strongly } \\
\text { increased amounts in wounded//crushed specimens) applied } \\
\text { on leaves of lettuce (well accepted food) }\end{array}$ & Inhibited feeding (antifeedant) $(0.01,0.1,1 \mathrm{ml} ; 0.83 \mathrm{~g} / \mathrm{ml})$ & Antifeedant experiment in glass plates & Wood et al. (2001) \\
\hline Oniscus asellus & Isopoda & Moulded food (not further specified) vs. sterilized food & $\begin{array}{l}\text { No volatile-mediated response, but preference for moulded food } \\
\text { after contact }\end{array}$ & $\begin{array}{l}\text { Video observation; four-chamber olfactometer; } \\
\text { groups of } 8 \text { individuals tested per run; } \\
\text { direct contact to the odour source was possible }\end{array}$ & Zidar et al. (2003) \\
\hline \multirow[t]{2}{*}{ Porcellio scaber } & Isopoda & $\begin{array}{l}\text { (a) Food with microorganisms (not further specified) } \\
\text { (b) Food without microorganisms }\end{array}$ & $\begin{array}{l}\text { (a) Attraction } \\
\text { (b) n.r. }\end{array}$ & Eight-chamber olfactometer; 1 individual tested per run & Zimmer et al. (1996) \\
\hline & & $\begin{array}{l}\text { Vocs identified from Tuber spp.: } \\
\text { (a) dimethyl sulphide } \\
\text { (b) 2-methyl propanal } \\
\text { (c) 2-butanone } \\
\text { (d) 2-methyl-butanol } \\
\text { (e) 2-methyl-butanal } \\
\text { (f) 3-methyl-butanol } \\
\text { (g) 3-methyl-butanal }\end{array}$ & $\begin{array}{l}\text { (a) Attraction of mycetophilous \& true hydnophagous insects } \\
\text { (b) n.r. } \\
\text { (c) n.r. } \\
\text { (d) n.r. } \\
\text { (e) n.r. } \\
\text { (f) n.r. } \\
\text { (g) Attraction of mycetophilous insects }\end{array}$ & Field traps for catching arthropods associated with Tuber spp. & Pacioni et al. (1991) \\
\hline
\end{tabular}

To be continued 
Table 1.1. Continuation

\section{FUNGI AS HOSTS}

\begin{tabular}{|c|c|c|c|c|c|}
\hline Orizaephilus surinamensis & 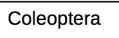 & VOCs characteristic for fungi: & & Circular two-choice piffall olfactometer (petri dish); & Pierce et al. (1991) \\
\hline Orizaephilus mercator & & (a) 3-octanol (racemic) & (a) $0.01-10 \mu \mathrm{g}$ : attraction (all species except C. quadricollis) & groups of 12 individuals tested per run; & \\
\hline Cryptolestes ferrugineus & & (b) 3-octanone (racemic) & (b) $0.01-100 \mu \mathrm{g}$ : attraction (all species except C. quadricollis) & test against control (solvent) & \\
\hline Ahasverus advena & & (c) 3-methylbutanol & (c) $0.01-1 \mu \mathrm{g}$ : attraction (all species) & & \\
\hline \multirow[t]{12}{*}{ Cathartus quadricollis } & & (d) 2-phenylethanol & (d) 2-phenylethanol & & \\
\hline & & (e) 1-octen-3-ol (racemic) & (e) $0.01-10 \mu$ l: attraction (all species except C. quadricollis); & & \\
\hline & & (f) $(R)-(-)-1$-octen-3-ol & (f) $0.0001 \mu \mathrm{g}: \mathrm{n.r.} ; 0.001-10 \mu \mathrm{gg}$ attraction; $100 \mu \mathrm{g}$ : repulsion & & \\
\hline & & (g) (S)-(+)-1-octen-3-ol & (g) $0.0001 \mu \mathrm{g}$ : n.r.; $0.001-10 \mu \mathrm{g}$ : attraction; $100 \mu \mathrm{g}$ : repulsion & & \\
\hline & Coleoptera & Fomitopsis pinicola & Attraction of 28 coleoptera taxa; & Field traps & Jonsell \& Nordlander (1995) \\
\hline & & Fomes fomentarius & $\begin{array}{l}\text { attraction of coleoptera colonizing deadwood; } \\
\text { strong attraction of Cildae to their host } F \text {. pinicola }\end{array}$ & & \\
\hline & Coleoptera & VOCs identified from wounded/chopped fruiting bodies of & & Field traps & Fäldt et al. (1999) \\
\hline & Lepidoptera & Formitopsis pinicola \& Fomes fomentarius: & (a) Attraction of Coleoptera Anaspis marginicollis, A. rufilabris, \& & & \\
\hline & & (a) 1-octen-3-ol (racemic) & Lepidoptera Ephinotia tedella & & \\
\hline & & (b) 3-octanone (racemic) & (b) n.r. & & \\
\hline & & (c) Blend: 3-octanone + 1-octen-3-ol & (c) Attraction of $P$. succicola, $A$. marginicollis \& A. rufilabris & & \\
\hline & & (d) Blend: 1-octanol + 3-octanol + 1-nonanol + 1-octen-3-ol & (d) Attraction of $A$. rufilabris \& E. tedella & & \\
\hline Octotemnus glabriculus & Coleoptera & (a) Fruiting bodies of Coriolus versicolor & (a) Atraction of C. bilamellatus, O. glabriculus \& C. boleti & Circular glass olfactometer with active airflow and the odour & Guevara et al. (2000a) \\
\hline Cis boleti & & (b) VOC filtrate of $\mathrm{C}$. versicolor & (c. nititdus: n.r.) & source placed outside at one side of the arena; & \\
\hline Cis nitidus & & (c) Fruiting bodies of Ganoderma adspersum & (b) Attraction of C. bilamellatus, O. glabriculus \& C. bolet $i$ & 1 individual tested per run & \\
\hline \multirow[t]{5}{*}{ Cis bilamellatus } & & (d) VOC filtrate of G. adspersum & (c. nittitus: n.r.) & & \\
\hline & & (e) Fruiting bodies of Piptoporus betulinus & (c) Attraction of C. bilamellatus \& C. nititdus (other species: n.r.) & & \\
\hline & & (f) VOC filtrate of $P$. betulinus & (d) Attraction of C. bilamellatus \& C. nitittus (other species: n.r.) & & \\
\hline & & & (e) Attraction of C. bilamellatus (other species: n.r.) & & \\
\hline & & & (f) Attraction of C. bilamellatus (other species: n.r.) & & \\
\hline Octotemnus glabriculus & Coleoptera & (a) Young fruiting bodies of $C$. versicolor & (a) Attraction of O. glabriculus (C. boleti: n.r.) & Circular glass olfactometer with active airflow and the odour & Guevara et al. (2000b) \\
\hline Cis boleti & & (b) Mature fruiting bodies of $\mathrm{C}$. versicolor & (b) Attraction of (both species) & $\begin{array}{l}\text { source placed outside at one side of the arena; } \\
1 \text { individual tested per run }\end{array}$ & \\
\hline \multirow[t]{3}{*}{ Bolitophagus reticulatus } & Coleoptera & (a) Fomes fomentarius & (a) Weak attraction (borderline significance) & Field traps & Jonsell et al. (2003) \\
\hline & & (b) Ethanol & (b) Attraction & & \\
\hline & & (c) F. fomentarius + ethanol & (c) Attraction & & \\
\hline \multirow[t]{3}{*}{ Cis boleti } & Coleoptera & (a) VOC filtrate of Trametes gibbosa & & & Thakeow et al. (2008) \\
\hline & & (b) $(R)-(-)-1-$ octen-3-ol & (b) Attraction \& increased searching activity & groups of 10 individuals tested per run; & \\
\hline & & (c) $(S)-(+)-1-$ octen-3-ol & (c) Attraction \& increased searching activity & test against control (solvent) & \\
\hline & Coleoptera & (a) Trametes versicolor & (a) Attraction of all species & Two-choice olfactometer; & Drilling \& Dettner (2009) \\
\hline Sulcaris affinis & & (b) VOC headspce sample of $T$. versicolor & (b) Attraction of all species & groups of 10 individuals tested per run; & \\
\hline Diaperis boleti & & (c) 1-octen-3-ol (concentration: $10^{2}$ ) & (c) Attraction of $T$. bipustulata \& S. affinis (D. boleti not tested) & treatments tested against control (medium, solvent) & \\
\hline Xyleborus glabratus & 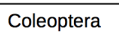 & (a) Raffaelea lauricola & (a) Attraction of $X$. glabratus (symbiont); & Two-choice olfactometer; & Hulcr et al. (2011) \\
\hline Xylosandrus crassiusculus & & (b) Ambrosiella xylebori & repulsion of $X$. crassiusculus, $X$. saxesenii & groups of 20 individuals tested per run; & \\
\hline
\end{tabular}

To be continued 
Table 1.1. Continuation

\begin{tabular}{|c|c|c|c|c|c|}
\hline $\begin{array}{l}\text { Xyleborus ferrugineus } \\
\text { xyleborinus saxesenii }\end{array}$ & & $\begin{array}{l}\text { (c) Ambrosiozyma ambrosiae } \\
\text { (d) Ethanol }\end{array}$ & $\begin{array}{l}\text { (b) Attraction of } X \text {. ferrugineus, } X \text {. crassiusculus (symbiont); } \\
\text { repulsion of } X \text {. glabratus } \\
\text { (c) Attraction of } X \text {. glagratus, } X \text {. ferrugineus (symbiont) } \\
\text { (d) Attraction of } X \text {. crassiusculus, } X \text {. ferrugineus }\end{array}$ & test against control (medium, solvent) & \\
\hline Bolitophagus reticulatus & Coleoptera & $\begin{array}{l}\text { VOCs identified from Fomes fomentarius: } \\
\text { (a) } 3 \text {-octanone }\left(10^{3}\right) \\
\text { (b) } 1 \text {-octen-3 ol }\left(10^{3}\right) \\
\text { (c) } 3 \text {-octanol }\left(10^{3}\right)\end{array}$ & $\begin{array}{l}\text { (a) Attraction } \\
\text { (b) Repellence } \\
\text { (c) n.r. }\end{array}$ & $\begin{array}{l}\text { Circular two-choice pitfall olfactometer (petri dish); } \\
\text { groups of } 6 \text { individuals of the same sex tested per run; } \\
\text { test against control (solvent) }\end{array}$ & Holighaus et al. (2014) \\
\hline Botanophila spp. & Diptera & $\begin{array}{l}\text { VOC identified from Epichloë typhina \& E. sylvatica: } \\
\text { Chokol K (racemic) }\end{array}$ & Attraction & Sticky field traps & Schiestl et al. (2006) \\
\hline Botanophila spp. & Diptera & $\begin{array}{l}\text { VOCs identified from Epichloë clarkii, E. festucae \& E. typhina: } \\
\text { Blend: Chokol K (racemic) + methyl (Z)-3- methyldodec-2-enoate }\end{array}$ & Attraction & Sticky field traps & Steinebrunner et al. (2008) \\
\hline Lycoriella ingenua & Diptera & $\begin{array}{l}\text { (a) Agaricus bisporus } \\
\text { (b) Trichoderma aggressivum }\end{array}$ & $\begin{array}{l}\text { (a) n.r. } \\
\text { (b) Attraction }\end{array}$ & Circular two-choice pitfall olfactometer (glass petri dish) & Cloonan et al. (2016a) \\
\hline Lycoriella ingenua & Diptera & $\begin{array}{l}\text { (a) Trichoderma aggressivum vs. Aspergillus niger } \\
\text { (b) } T \text {. aggressivum vs. Aspergillus flavus } \\
\text { (c) } T \text {. aggressivum vs. Aspergillus fumigatus } \\
\text { (d) } T \text {. aggressivum vs. Penicillium citrinum } \\
\text { (e) } T \text {. aggressivum vs. Scatylidium thermophilum } \\
\text { (f) } T \text {. aggressivum vs. Chaetomium sp. }\end{array}$ & $\begin{array}{l}\text { (a) T. aggressivum preferred } \\
\text { (b) T. aggressivum preferred } \\
\text { (c) T. aggressivum preferred } \\
\text { (d) n.r. } \\
\text { (e) n.r. } \\
\text { (f) } T \text {. aggressivum preferred }\end{array}$ & $\begin{array}{l}\text { Circular two-choice pitfall olfactometer (glass petri dish); } \\
1 \text { individual tested per run }\end{array}$ & Cloonan et al. (2016b) \\
\hline Aradus abtectus & Heteroptera & $\begin{array}{l}\text { (a) Mycelium of Fomitopsis pinicola } \\
\text { (b) Fruiting body of Fomitopsis pinicola }\end{array}$ & $\begin{array}{l}\text { (a) Attraction } \\
\text { (b) Repellence }\end{array}$ & $\begin{array}{l}\text { Olfactometer }(60 \mathrm{~cm}) \text { with active airflow; no-choice assay; } \\
1 \text { individual tested per run }\end{array}$ & Koban et al. (2016) \\
\hline Sirex noctilio & Hymenoptera & Amylostereum areolatum vs. A. chailletii & A. areolatum preferred by mated females & Walk-in flight tunnel two-choice olfactometer & Sarvary et al. (2016) \\
\hline & & FUNGI AS 'NICHE & CONSTRUCTORS' \& COMPE & rORS & \\
\hline $\begin{array}{l}\text { Carpophilus hemipterus } \\
\text { Carpophilus lugubris }\end{array}$ & Coleoptera & Fruit substrate infected with Saccharomyces cerevisiae & Attraction increased compared with uninfected fruits & $\begin{array}{l}\text { Flight tunnel olfactometer with active airflow; } \\
\text { test against control (uninfected fruits) }\end{array}$ & Blackmer \& Phelan (1991) \\
\hline Carpophilus lugubris & Coleoptera & $\begin{array}{l}\text { VOCs identified from fruits \& bread dough inoculated with } \\
\text { Candida krusei, Saccharomyces cerevisiae: } \\
\text { (a) Synthetic bread dough blend: acetaldehyde + ethanol + } \\
\text { 1-propanol + ethyl acetate + 2-methylpropanol + 3-methylbutanol } \\
\text { + 2-methylbutanol } \\
\text { (b) Blend 1: acetaldehyde + ethyl acetate } \\
\text { (c) Blend } 1+\text { ethanol } \\
\text { (d) Blend 1 +1-propanol } \\
\text { (e) Blend 1 + 2-methylpropanol } \\
\text { (f) Blend 1 + 3-methylbutanol } \\
\text { (g) Blend 1 + 2-methylbutanol } \\
\text { (h) Blend 2: acetaldehyde + 2-methylpropanol } \\
\text { (i) Blend 2 + ethyl acetate }\end{array}$ & $\begin{array}{l}\text { (a) Full blend: attraction; blend without any of the alcohols or } \\
\text { ethyl acetate: attraction; blend without acetaldehyde: reduced } \\
\text { attraction; blend without all alcohols: reduced attraction } \\
\text { (b) n.r. } \\
\text { Attractivity ranking: (a) }=(\mathrm{e})>\text { (f) }=(\mathrm{g})>\text { (d) }>\text { (c) }\end{array}$ & $\begin{array}{l}\text { Flight tunnel olfactometer with active airllow; } \\
\text { groups of } 10 \text { individuals tested per run; } \\
\text { test against control (empty) }\end{array}$ & Lin \& Phelan (1991) \\
\hline
\end{tabular}

To be continued 


\section{Table 1.1. Continuation}

\begin{tabular}{|c|c|c|c|c|c|}
\hline & & $\begin{array}{l}\text { (j) Blend } 2+\text { ethanol } \\
\text { (k) Blend 2 + 1-propanol } \\
\text { (l) Blend 2 + 3-methylbutanol + 2-methylbutanol } \\
\text { (m) Blend 3: acetaldehyde + 2-methylpropanol + 3-methylbutanol } \\
\text { (n) Blend } 3 \text { + ethyl acetate } \\
\text { (o) Blend } 3 \text { + ethanol } \\
\text { (p) Blend 3 + 1-propanol }\end{array}$ & Attractivity ranking: $(a)=(n)=(0)>(m)=(p)$ & & \\
\hline Carpophilus hemipterus & Coleoptera & $\begin{array}{l}\text { (a) Saccharomyces cerevisiae } \\
\text { (b) Blend of VOCs identified from S. cerevisiae (1): } \\
\text { acetaldehyde + ethanol + propanol + 2-butanone + ethyl acetate + } \\
\text { 2-methylpropanol + butanol + 2-pentanone + 2-pentanol + } \\
\text { 3-hydroxy-2-butanone + 3-methylbutanol + isobutyl acetate + } \\
\text { ethyl butyrate + ethyl isovalerate + isopentyl acetate + } \\
\text { isopentyl butyrate + isopentyl isovalerate } \\
\text { (c) Blend of VOCs identified from S. cerevisiae (2): } \\
\text { ethyl acetate + acetaldehyde + 2-pentanol + 3-methylbutanol }\end{array}$ & $\begin{array}{l}\text { (a) Attraction } \\
\text { (b) Attraction } \\
\text { (c) Attraction }\end{array}$ & $\begin{array}{l}\text { Flight tunnel olfactometer with active airflow; } \\
\text { groups of } 10 \text { individuals tested per run; } \\
\text { test against control (sterile fruit) }\end{array}$ & Phelan \& Lin (1991) \\
\hline $\begin{array}{l}\text { Carpophilus hemipterus } \\
\text { Carpophilus lugubris } \\
\text { Stelidota geminata }\end{array}$ & Coleoptera & $\begin{array}{l}\text { (a) Ceratocystis fagacearum } \\
\text { (b) Xerula radicata } \\
\text { (c) Pluteus atricapillus } \\
\text { (d) Tyromyces chioneus } \\
\text { (e) Botrytis cinerea }\end{array}$ & $\begin{array}{l}\text { (a) Attraction } \\
\text { (b) Attraction } \\
\text { (c) n.r. } \\
\text { (d) n.r. } \\
\text { (e) n.r. }\end{array}$ & $\begin{array}{l}\text { Flight tunnel olfactometer with active airflow; } \\
\text { groups of } 10 \text { individuals tested per run; } \\
\text { test against control (empty) }\end{array}$ & Lin \& Phelan (1992) \\
\hline Carpophilus humeralis & Coleoptera & $\begin{array}{l}\text { (a) Saccharomyces cerevisiae } \\
\text { (b) Candida guilliermondii } \\
\text { (c) Candida shehatae } \\
\text { (d) Blend of VoCs identified from S. cerevisiae: } \\
\text { ethanol + acetaldehyde + 2-methylpropanol + 1-propanol + } \\
\text { ethyl acetate + 2-methylbutanol } \\
\text { (e) Blend of VOCs identified from C. guilliermondili: } \\
\text { ethanol + 2-methylpropanol + 3-hydroxy-2-butanone } \\
\text { (f) Blend: ethanol + 2-methylpropanol } \\
\text { (g) 3-hydroxy-2-butanone }\end{array}$ & $\begin{array}{l}\text { (a) Attraction } \\
\text { (b) Attraction, but less compared to S. cerevisiae, C. shehatae } \\
\text { (c) Attraction } \\
\text { (d) Attraction } \\
\text { (e) Attraction } \\
\text { (f) n.r. } \\
\text { (g) Attraction }\end{array}$ & $\begin{array}{l}\text { Flight tunnel olfactometer with active airflow; } \\
\text { groups of 500-1000 individuals tested per run }\end{array}$ & Nout \& Bartelt (1998) \\
\hline Xestobium rufovillosum & Coleoptera & $\begin{array}{l}\text { (a) Donkioporia expansa } \\
\text { (b) Coriolus versicolor } \\
\text { (c) Wood infected with D. expansa, C. versicolor, Fistulina hepatica }\end{array}$ & $\begin{array}{l}\text { (a) Attraction } \\
\text { (b) Attraction } \\
\text { (c) Attraction }\end{array}$ & $\begin{array}{l}\text { Flight tunnel olfactometer with active airflow; } \\
\text { groups of } 5 \text { individuals tested per run; } \\
\text { test against control (empty) }\end{array}$ & Belmain et al. (2002) \\
\hline Drosophila spp. & Diptera & Different yeast species & Different yeast spp. attracted different Drosophila spp. & Field traps & Dobzhansky et al (1956) \\
\hline Drosophila melanogaster & Diptera & $\begin{array}{l}\text { (a) Odour sample of fermented grape juice (S. cerevisiae) } \\
\text { (b) Blend of S. cerevisiae characteristic VoCs: } \\
\text { Acetoin + acetic acid + 3-methyl-1-butanol + 2-phenyl-ethanol +ethanol }\end{array}$ & $\begin{array}{l}\text { (a) Attraction } \\
\text { (b) Attraction }\end{array}$ & $\begin{array}{l}\text { Flight tunnel olfactometer with active airflow; no-choice assay; } \\
\text { groups of } 20 \text { female individuals tested per run; }\end{array}$ & Becher et al. (2012) \\
\hline
\end{tabular}

To be continued 
Table 1.1. Continuation

\begin{tabular}{|c|c|c|c|c|c|}
\hline Drosophila melanogaster & Diptera & $\begin{array}{l}\text { (a) Saccharomyces cerevisiae (different isolates) } \\
\text { (b) Saccharomyces bayanus (different isolates) } \\
\text { (c) Saccharomyces uvarum (different isolates) } \\
\text { (d) Saccharomyces paradoxus (different isolates) } \\
\text { (e) Saccharomyces kudriavezii } \\
\text { (f) Hanseniaspora uvarum } \\
\text { (g) Pichia kluyveri } \\
\text { (h) Candida railenensis } \\
\text { (i) Kluveromyces aestuarii } \\
\text { (j) Kazachstania telluris } \\
\text { (k) Kluveromyces polysporus } \\
\text { (l) Torulaspora delbrueckii } \\
\text { (m) Candida castellii } \\
\text { (n) Kluveromyces thermotolerans } \\
\text { (o) Zygosacharomyces mrakii } \\
\text { (p) Saccharomyces spp. vs non-Saccharomyces spp. }\end{array}$ & $\begin{array}{l}\text { (a) Attraction: } 13 \text { isolates; n.r.: } 1 \text { isolate; repellence: } 2 \text { isolates } \\
\text { (b) Attraction } \\
\text { (c) Attraction: } 3 \text { isolates; n.r.: } 1 \text { isolate; repellence: } 1 \text { isolate } \\
\text { (d) Attraction: } 2 \text { isolates; n.r. } 2 \text { isolates; repellence: } 1 \text { isolate } \\
\text { (e) Atraction } \\
\text { (f) Attraction } \\
\text { (g) Attraction } \\
\text { (h) n.r. } \\
\text { (i) n.r. } \\
\text { () n.r. } \\
\text { (k) n.r. } \\
\text { (l) n.r. } \\
\text { (m) Repellence } \\
\text { (n) Repellence } \\
\text { (o) Repellence } \\
\text { (p) Saccharomyces spp. preferred }\end{array}$ & $\begin{array}{l}\text { Two-choice olfactometer; } \\
\text { groups of 70-80 individuals tested per run; } \\
\text { test against control (medium: sterile grape juice) }\end{array}$ & Palanca et al. (2013) \\
\hline Drosophila simulans & Diptera & $\begin{array}{l}\text { Odour sample of fermented grape juice } \\
\text { (different genotypes of Saccharomyces cerevisiae) }\end{array}$ & Attraction (27 genotypes); repulsion (5 genotypes) & $\begin{array}{l}\text { Two-arm olfactometer; groups of } 3 \text { individuals tested per run; } \\
\text { test against control (medium: sterile grape juice) }\end{array}$ & Buser et al. (2014) \\
\hline Drosophila melanogaster & Diptera & 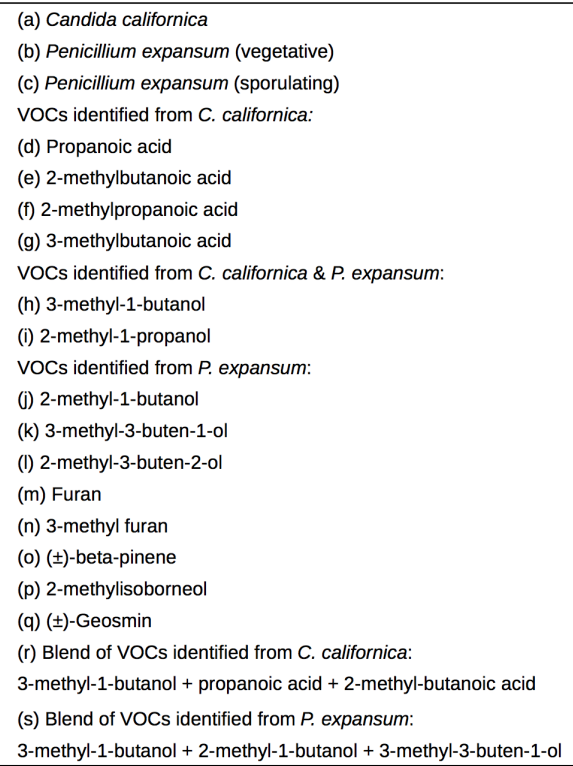 & $\begin{array}{l}\text { (a) Attraction } \\
\text { (b) Attraction } \\
\text { (c) Attraction } \\
\text { (d) } 10^{-1}: \text { attraction; } 10^{-4}: \text { n.r. } \\
\text { (e) } 10^{-1} \text { attraction; } 10^{-4} \text { n.r. } \\
\text { (f) n.r. } \\
\text { (g) n.r. } \\
\text { (h) } 10^{-1}: \text { attraction; } 10^{-4}: \text { n.r. } \\
\text { (i) n.r. } \\
\text { () } 10^{-1}: \text { attraction; } 10^{-4}: \text { n.r. } \\
\text { (k) } 10^{-1} \text { attraction; } 10^{4}: \text { n.r. } \\
\text { (l) n.r. } \\
\text { (m) n.r. } \\
\text { (n) n.r. } \\
\text { (o) n.r. } \\
\text { (p) n.r. } \\
\text { (q) n.r. } \\
\text { (r) } 10^{-1}, 10^{-2}, 10^{-3}: \text { Attraction } \\
\text { (s) } 10^{-1}, 10^{-2}: \text { Attraction; } 10^{-3}: \text { n.r. }\end{array}$ & $\begin{array}{l}\text { Circular olfactometer; } 1 \text { individual tested per run; } \\
\text { no-choice assay }\end{array}$ & Stötefeld et al. (2015) \\
\hline
\end{tabular}

To be continued 
Table 1.1. Continuation

\begin{tabular}{|c|c|c|c|c|c|}
\hline $\begin{array}{l}\text { Drosophila melanogaster } \\
\text { Drosophila suzukii }\end{array}$ & Diptera & $\begin{array}{l}\text { Saccharomyces cerevisiae } \\
\text { Hanseniaspora uvarum } \\
\text { Pichia terricola } \\
\text { Pichia kluyveri } \\
\text { Candida californica } \\
\text { Candida zemplinina }\end{array}$ & $\begin{array}{l}\text { Attraction of both Drosophila spp. to all yeast species; } \\
\text { Strongest attraction of } D \text {. melanogaster to } H \text {. uvarum \& } \\
\text { P. terricola; } \\
\text { Strongest attraction of } D \text {. suzukii to } H \text {. uvarum }\end{array}$ & $\begin{array}{l}\text { Two-choice olfactometer; } \\
\text { groups of } 20 \& 60 \text { individuals tested per run; } \\
\text { test against control (medium) }\end{array}$ & Scheidler et al. (2015) \\
\hline Drosophila melanogaster & Diptera & $\begin{array}{l}\text { (a) Saccharomyces cerevisiae } \\
\text { (b) Hanseniaspora uvarum } \\
\text { (c) Candida californica } \\
\text { (d) Pichia membranifaciens } \\
\end{array}$ & $\begin{array}{l}\text { (a) Attraction } \\
\text { (b) Attraction } \\
\text { (c) Attraction } \\
\text { (d) Attraction }\end{array}$ & $\begin{array}{l}\text { Two-arm olfactometer; } \\
\text { groups of } 40-130 \text { individuals tested per run; } \\
\text { test against control }\end{array}$ & Fischer et al (2017) \\
\hline Lobesia botrana & Lepidoptera & Grapes infected with Botrytis cinerea vs. uninfected grapes & Infected grapes preferred & $\begin{array}{l}\text { Eight-chamber olfactometer with active airflow; } \\
\text { groups of } 35 \text { larvae tested per run }\end{array}$ & Mondy et al. (1998) \\
\hline Lobesia botrana & Lepidoptera & $\begin{array}{l}\text { (a) Grapes infected with yeasts: Saccharomyces cerevisiae, } \\
\text { Zygosaccharomyces rouxii, Metschnikowia pulcherrima, } \\
\text { Hanseniaspora uvarum, Pichia anomala } \\
\text { (b) Grapes infected with Botrytis cinerea }\end{array}$ & $\begin{array}{l}\text { (a) Attraction, preferred oviposition site } \\
\text { (b) Repellence, reduced oviposition }\end{array}$ & $\begin{array}{l}\text { Two-choice olfactometer oviposition assay; } \\
1 \text { individual tested per run; } \\
\text { test against control (uninfected grapes) }\end{array}$ & Tasin et al. (2011) \\
\hline \multirow[t]{2}{*}{ Cydia pomonella } & Lepidoptera & Metschnikowia andauensis & Atraction & $\begin{array}{l}\text { Flight tunnel olfactometer with active airflow; } \\
\text { groups of } 10 \text { females tested per run; test against control }\end{array}$ & Witzgall et al. (2012) \\
\hline & & FUNGI AS & PATHOGENS \& PREDATORS & & \\
\hline Hylobius abietis & Coleoptera & $\begin{array}{l}\text { VOCs identified from P. expansum: } \\
\text { (a) Styrene + pine twigs } \\
\text { (b) 3-methylanisole + pine twigs }\end{array}$ & $\begin{array}{l}\text { (a) Reduced attraction compared to pine twigs without styrene } \\
\text { (b) Reduced attraction of males compared to pine twigs without } \\
\text { 3-methylanisole }\end{array}$ & $\begin{array}{l}\text { Circular multi-choice pitfall olfactometer; } \\
\text { groups of } 50 \text { male \& female individuals tested per run; } \\
\text { test against controls (empty, fresh pine twigs) }\end{array}$ & Azeem et al. (2013) \\
\hline Drosophila melanogaster & Diptera & Geosmin + Vinegar & Geosmin reduced attraction to vinegar & $\begin{array}{l}\text { Flight tunnel olfactometer with active airflow; } \\
\text { groups of } 20 \text { female individuals tested per run; } \\
\text { test against control (distilled water) }\end{array}$ & Becher et al. (2010) \\
\hline Musca domestica & Diptera & $\begin{array}{l}\text { VOCs identified from potential pathogenic fungi Phoma sp., } \\
\text { Rhizopus sp., Fusarium sp.: } \\
\text { (a) Dimethyl trisulfide } \\
\text { (b) 2-phenylethanol } \\
\text { (c) Citronellal } \\
\text { (d) Norphytone }\end{array}$ & $\begin{array}{l}\text { (a) Reduction of oviposition activity } \\
\text { (b) Reduction of oviposition activity } \\
\text { (c) n.r. } \\
\text { (d) n.r. }\end{array}$ & $\begin{array}{l}\text { Two-choice olfactometer oviposition assay; } \\
\text { groups of } 40 \text { individuals tested per run; } \\
\text { test against control (empty) }\end{array}$ & Lam et al (2010) \\
\hline $\begin{array}{l}\text { Lariophagus distinguendus } \\
\text { (parasitoid of Sitophilus granarius) }\end{array}$ & Hymenoptera & $\begin{array}{l}\text { (a) Aspergillus sydowii vs. control (medium: grain) } \\
\text { (b) Aspergillus versicolor vs. control (medium: grain) } \\
\text { (c) Larval feces with fungi vs. control (filter paper) } \\
\text { (d) Fungal-free larval feces vs. control (filter paper) } \\
\text { (e) Larval feces + fungi vs. fungal-free feces } \\
\text { (f) 1-octen-3-ol vs. control (solvent) }\end{array}$ & $\begin{array}{l}\text { (a) Avoidance of } A \text {. sydowii } \\
\text { (b) Avoidance of A. versicolor } \\
\text { (c) Avoidance of larval feces with fungi } \\
\text { (d) Fungal-free larval feces preferred } \\
\text { (e) Fungal-free larval feces preferred } \\
\text { (f) Avoidance of 1-octen-3-ol }\end{array}$ & Four-chamber olfactometer; 1 individual tested per run & Steiner et al. (2007) \\
\hline Macrotermes michaelseni & Isoptera & $\begin{array}{l}\text { Metarhizium anisopliae (different isolates) } \\
\text { Beauveria bassiana (different isolates) }\end{array}$ & $\begin{array}{l}\text { Repellence; positive correlation of isolate virulence \& repellence; } \\
\text { M. anisopliae more virulent \& repellent than B. bassiana }\end{array}$ & $\begin{array}{l}\text { Two-arm olfactometer with active airflow; } \\
\text { test against control (empty) }\end{array}$ & Mburu et al. (2009) \\
\hline
\end{tabular}

To be continued 
Table 1.1. Continuation

\begin{tabular}{|c|c|c|c|c|c|}
\hline Macrotermes michaelseni & Isoptera & $\begin{array}{l}\text { (a) Blend of VOCs identified from Metarhizium anisopliae } \\
\text { (highly repellent \& virulent isolate): } \\
\text { Hexanol + 3-octanone + acetic acid + 1-octene + 2-nonanone + } \\
\text { 2-nonanol + phenylethyl alcohol + 3-nonen-2-one + borneol + } \\
\text { 4,5-dihydro-5-pentyl-2(3H)furanone } \\
\text { (in addition, 9-component blends with each compound substracted } \\
\text { one at a time were tested) } \\
\text { (b) Blend of VOCs identified from Metarhizium anisopliae } \\
\text { (less repellent \& virulent isolate): } \\
\text { Hexanol + 3-octanol + n-ethylacetamide + 1-octen-3-ol + cedrene } \\
\text { + butylolactone + phenylethyl alcohol + 1-ethyl-2-methylbenzene + } \\
\text { 2-propyl-1-pentanol + 2-pyrrolidinone }\end{array}$ & $\begin{array}{l}\text { (a) More repellent than (b); } \\
\text { 4,5-dihydro-5-pentyl-2(3H)furanone contributed most to the } \\
\text { repellency of the highly virulent isolate; } \\
\text { 2-pyrrolidinone contributed most to the repellency of the less } \\
\text { virulent isolate }\end{array}$ & Two-arm olfactometer with active airflow & Mburu et al. (2011) \\
\hline Coptotermes formosanus & Isoptera & $\begin{array}{l}\text { VOC solutions obtained from conidia of } \\
\text { Metarhizium anisopliae (highly virulent and less virulent isolate) } \\
\text { Beauveria brongniartit (highly virulent and less virulent isolate) } \\
\text { Isaria fumosorosea (highly virulent and less virulent isolate) } \\
\text { applied on conspecifics }\end{array}$ & Increased grooming activity in the presence of fungi & $\begin{array}{l}\text { Observation of grooming behaviour with photographs; } \\
\text { groups of } 5 \text { individuals tested per run; } \\
\text { test against control }\end{array}$ & Yanagawa et al. (2011) \\
\hline Coptotermes formosanus & Isoptera & $\begin{array}{l}\text { Metarhizium anisopliae (highly virulent and less virulent isolate) } \\
\text { Beauveria brongniarti (highly virulent and less virulent isolate) } \\
\text { Isaria fumosorosea (highly virulent and less virulent isolate) }\end{array}$ & $\begin{array}{l}\text { Avoidance of all species \& isolates except from the less virulent } \\
\text { isolate of } M \text {. anisopliae }\end{array}$ & $\begin{array}{l}\text { Two-choice olfactometer; test against control; } \\
1 \text { individual tested per run }\end{array}$ & Yanagawa et al. (2012) \\
\hline Macrotermes michaelseni & Isoptera & $\begin{array}{l}\text { (a) Blend of VOCs identified from Beauveria bassiana } \\
\text { (highly repellent \& virulent isolate): } \\
\text { Hexanol + (R,S)-4,5-Dihydro-5-pentyl-2-( } 3 \text { H)furanone + 3-octanol } \\
+ \text { 1-pentanol + camphor + butyrylactone + }(R, S) \text {-borneol + } \\
\text { 4-nonanone + octanol + 2-nonanone } \\
\text { (in additition, 9-component blends with each compound substracted } \\
\text { one at a time were tested) } \\
\text { (b) Blend of VOCs identified from Beauveria bassiana } \\
\text { (less repellent \& virulent isolate): } \\
\text { Hexanol + }(R, S)-4,5 \text {-Dihydro-5-pentyl-2-(3 H)furanone + 3-octanol } \\
+ \text { 1-pentanol + camphor + butyrolactone + (R,S)-borneol + } \\
\text { 4-nonanone + octanol + 2-nonanone } \\
\text { (different amounts of compounds between blends (a) \& (b)) }\end{array}$ & $\begin{array}{l}\text { (a) More repellent than (b); } \\
\text { 4,5-dihydro-5-pentyl-2(3H)furanone contributed most to the } \\
\text { repellency of both isolates, with higher amounts in the more } \\
\text { repellent \& virulent isolate; } \\
\text { Borneol also strongly contributed to repellency of } B \text {. bassiana, } \\
\text { and is also more abundant in the more virulent isolate }\end{array}$ & Two-arm olfactometer with active airflow & Mburu et al. (2013) \\
\hline Coptotermes formosanus & Isoptera & $\begin{array}{l}\text { (a) Conidia suspension of Isaria fumosorosea } \\
\text { vocs identified from I. fumosorosea: } \\
\text { (b) 3-octanone } \\
\text { (c) 1-octen-3-ol }\end{array}$ & $\begin{array}{l}\text { (a) Avoidance (positively correlated with concentration) } \\
\text { (b) Avoidance } \\
\text { (c) n.r. }\end{array}$ & $\begin{array}{l}\text { Two-choice olfactometer; test against control (solvent); } \\
1 \text { individual tested per run }\end{array}$ & Yanagawa et al. (2015) \\
\hline Lobesia botrana & Lepidoptera & $\begin{array}{l}\text { (a) Grapes infected with Botrytis cinerea } \\
\text { vocs identified from Botrytis cinerea infected grapes: } \\
\text { (b) Ethanol } \\
\text { (c) 3-methyl-1-butanol } \\
\text { (d) 3-methyl-1-butanol in the presence of grapes }\end{array}$ & $\begin{array}{l}\text { (a) Repellence, reduced oviposition } \\
\text { (b) n.r. } \\
\text { (c) } 1 \mu \mathrm{g}: \mathrm{nr.r} ; 10 \mu \mathrm{g} \text { : enhanced oviposition; } 100 \mu \mathrm{g}: \mathrm{n.r} \text {. } \\
\text { (d) } 1 \mu \mathrm{g} \text { n.r.; } 10 \mu \mathrm{g} \text { : enhanced oviposition; } 100 \mu \mathrm{g} \text { : n.r. }\end{array}$ & $\begin{array}{l}\text { Flight tunnel olfactometer with active airflow; } \\
\text { groups of } 10 \text { mated females tested per run } \\
\text { Two-choice olfactometer oviposition assay; } \\
1 \text { individual tested per run } \\
\text { test against control (uninfected grapes, solvent) }\end{array}$ & Tasin et al. (2012) \\
\hline
\end{tabular}

To be continued 
Table 1.1. Continuation

\begin{tabular}{|c|c|c|c|c|c|}
\hline Epiphyas postvittana & Lepidoptera & $\begin{array}{l}\text { (a) Grapes infected with Botrytis cinerea } \\
\text { vocs identified from Botrytis cinerea infected grapes: } \\
\text { (b) Ethanol } \\
\text { (c) 3-methyl-1-butanol } \\
\text { (d) Ethanol in the presence of grapes } \\
\text { (e) 3-methyl-1-butanol in the presence of grapes }\end{array}$ & $\begin{array}{l}\text { (a) Repellence } \\
\text { (b) } 10,100,1000 \mu g: \text { n.r. } \\
\text { (c) } 10 \mu g \text { : attraction, enhanced oviposition; } 100 \mu g: \text { n.r. } \\
\text { (d) } 10,100 \mu g: \text { n.r; } 1000 \mu g \text { : repellence, reduced oviposition } \\
\text { (e) } 10 \mu g \text { : n.r.; } 100 \mu g \text { : repellence, reduced oviposition }\end{array}$ & $\begin{array}{l}\text { Flight tunnel olfactometer with active airflow; } \\
\text { groups of } 4 \text { males or females tested per run } \\
\text { Two-choice olfactometer oviposition assay } \\
\text { test against control (solvent) }\end{array}$ & Rizvi \& Raman (2016) \\
\hline Caenorhabditis elegans & Nematoda & $\begin{array}{l}\text { (a) Arthrobotrys oligospora (nematophagous) } \\
\text { vocs identified from Arthrobotrys oligospora: } \\
\text { (b) Dimethyl disulfide } \\
\text { (c) (I)-2-methyl-1-butanol } \\
\text { (d) 2,4-dithiapentane } \\
\text { (e) Methyl 3-methyl-2-butenoate } \\
\text { (f) S-methyl thioacetate }\end{array}$ & $\begin{array}{l}\text { (a) Attraction } \\
\text { (b) Moderate attraction } \\
\text { (c) Strong attraction } \\
\text { (d) Strong attraction } \\
\text { (e) Strong attraction } \\
\text { (f) Strong attraction }\end{array}$ & $\begin{array}{l}\text { Circular two-choice olfactometer; test against control; } \\
\text { groups of individuals tested per run; } \\
\text { test against control (solvent, medium) }\end{array}$ & Hsueh et al. (2017) \\
\hline Bursaphelenchus xylophilus & Nematoda & $\begin{array}{l}\text { (a) VOC filtrate of Esteya vermicola (nematophagous): } \\
\text { VOCs identified from E. vermicola: } \\
\text { (b) Alpha-pinene } \\
\text { (c) Beta-pinene } \\
\text { (d) Camphor } \\
\text { (e) Blend: (b) + (c) + (d) }\end{array}$ & $\begin{array}{l}\text { (a) Attraction } \\
\text { (b) } 50 \mathrm{ng}: \text { attraction; } 28 \mathrm{ng} \text { n.r. } \\
\text { (c) } 12 \mathrm{ng} \text { : attraction; } 6 \mathrm{ng}: \text { n.r. } \\
\text { (d) } 1.6 \mathrm{ng} \text { : attraction; } 1 \mathrm{ng} \text { : n.r. } \\
\text { (e) } 41 \mathrm{ng} \text { : attraction; } 20.5 \mathrm{ng} \text { : n.r. }\end{array}$ & $\begin{array}{l}\text { Two-choice olfactometer; test against control (solvent); } \\
\text { groups of }-200 \text { individuals tested per run }\end{array}$ & Lin et al. (2013) \\
\hline & & FUNGI IN & A MULTITROPHIC CONTEXT & & \\
\hline $\begin{array}{l}\text { Hypoaspis aculeifer } \\
\text { (predacious; prey: collembola) }\end{array}$ & Acari & $\begin{array}{l}\text { (a) Alternaria alternata vs. control (medium) } \\
\text { (b) A. alternata vs. A. alternata grazed by collembola (prey) } \\
\text { (c) A. alternata vs. medium + collembola odour }\end{array}$ & $\begin{array}{l}\text { (a) A. alternata preferred } \\
\text { (b) n.p. } \\
\text { (c) A. alternata preferred }\end{array}$ & Circular two-choice olfactometer (petri dish) & Hall \& Hedlund (1999) \\
\hline $\begin{array}{l}\text { Hypoaspis aculeifer } \\
\text { (predacious; prey: collembola) }\end{array}$ & Acari & $\begin{array}{l}\text { (a) T. viride vs. control (medium) } \\
\text { (b) T. viride vs. T. viride grazed by collembola (prey) } \\
\text { (c) T. viride vs. collembola } \\
\text { (d) T. viride grazed by collembola vs. control } \\
\text { (e) T. viride grazed by collembola vs. collembola } \\
\text { (f) Collembola vs. control }\end{array}$ & $\begin{array}{l}\text { (a) } T \text {. viride preferred } \\
\text { (b) n.p. } \\
\text { (c) n.p. } \\
\text { (d) } T \text {. viride grazed by collembola preferred } \\
\text { (e) n.p. } \\
\text { (f) n.p. }\end{array}$ & $\begin{array}{l}\text { Two-choice olfactometer filled with soil; } \\
\text { groups of } 30 \text { individuals tested per run }\end{array}$ & Pfeffer \& Filser (2010) \\
\hline $\begin{array}{l}\text { Araecerus fasciculatus } \\
\text { (herbivorous) }\end{array}$ & Coleoptera & $\begin{array}{l}\text { (a) Kluyveromyces lactis } \\
\text { vOCs identified from } K \text {. lactis } \\
\text { (b) 3-methylbutyl acetate } \\
\text { (c) 2-methylbutyl actetate } \\
\text { (d) furfuryl acetate } \\
\text { (e) 2-phenylethanol } \\
\text { (f) 2-phenylethyl acetate } \\
\text { (g) 2-phenylethyl propionate } \\
\text { (h) 2-phenylethyl isobutyrate } \\
\text { (i) 2-phenylethyl butyrate }\end{array}$ & 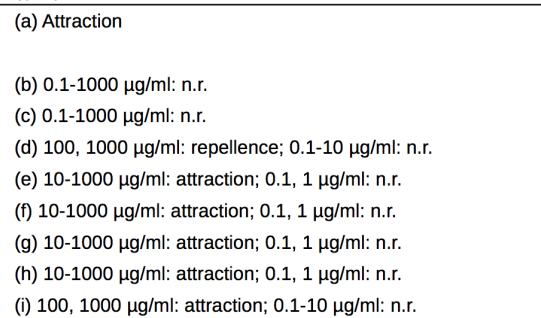 & $\begin{array}{l}\text { Two-arm olfactometer with active airflow; } \\
1 \text { individual tested per run; } \\
\text { test against control (medium, solvent) }\end{array}$ & Yang et al (2017) \\
\hline
\end{tabular}

To be continued 
Table 1.1. Continuation

\begin{tabular}{|c|c|c|c|c|c|}
\hline $\begin{array}{l}\text { Ibalia leucospoides } \\
\text { (parasitoid of Sirex noctilio) }\end{array}$ & Hymenoptera & Amylostereum areolatum & $\begin{array}{l}\text { Antenna movement was identical to that observed in repsonse } \\
\text { to suitably aged prey \& parasitoids adopted searching in re- } \\
\text { sponse to the fungal odour source (antennae lowered) }\end{array}$ & Direct observation of antenna movement of female individuals & Madden (1968) \\
\hline $\begin{array}{l}\text { Asobara tabida } \\
\text { (isolated from S. cerevisiae \& } \\
\text { Beta vulgaris microhabitats) } \\
\text { (parasitoid of D. melanogaster) }\end{array}$ & Hymenoptera & Saccharomyces cerevisiae & $\begin{array}{l}\text { Attraction of } A \text {. tabida from the yeast microhabitat } \\
\text { (A. tabida from the beet habitat: } n . r . \text { ) }\end{array}$ & Four-arm olfactometer with active airflow (first choice); & Vet et al. (1984) \\
\hline $\begin{array}{l}\text { Leptophilina heterotoma } \\
\text { (parasitoid of } D . \text { melanogaster) }\end{array}$ & Hymenoptera & $\begin{array}{l}\text { (a) Saccharomyces cerevisiae + host } \\
\text { (b) S. cerevisiae } \\
\text { (c) Host } \\
\text { (d) Dead S. cerevisiae vs. living S. cerevisiae } \\
\text { (e) S. cerevisiae + sugar vs. S. cerevisiae } \\
\text { vOCs identified from Saccharomyces cerevisiae: } \\
\text { (f) Ethanol } \\
\text { (g) Acetaldehyde } \\
\text { (h) Ethyl acetate } \\
\text { (i) Acetic acid } \\
\text { (j) Formaldehyde } \\
\text { (k) Methanol } \\
\text { (l) Diacetyl } \\
\text { (m) Ethanol + yeast } \\
\text { (n) Acetaldehyde + yeast } \\
\text { (o) Blend: ethanol + acetaldehyde + ethyl acetate vs. yeast }\end{array}$ & $\begin{array}{l}\text { (a) Attraction } \\
\text { (b) Attraction } \\
\text { (c) n.r. } \\
\text { (d) Living yeast preferred, attraction } \\
\text { (e) n.p. } \\
\text { (f) Attraction } \\
\text { (g) Atraction } \\
\text { (h) Attraction } \\
\text { (i) n.r. } \\
\text { (i) n.r. } \\
\text { (k) n.r. } \\
\text { (I) n.r. } \\
\text { (m) Attraction stronger compared to ethanol alone } \\
\text { (n) Attraction stronger compared to yeast \& acetaldehyde alone } \\
\text { (o) Blend less attractive than yeast S. cerevisiae } \\
\end{array}$ & $\begin{array}{l}\text { Video observation in an olfactometer with active airflow; } \\
\text { first, second, final choice observed to detect arresting; } \\
1 \text { female individual tested per run }\end{array}$ & Dicke et al. (1984) \\
\hline $\begin{array}{l}\text { Roptrocerus xylophagorum } \\
\text { Spathius pallidus } \\
\text { (parasitoids of Scolytidae) }\end{array}$ & Hymenoptera & $\begin{array}{l}\text { (a) Ophiostoma ips } \\
\text { (b) Ophiostoma minus }\end{array}$ & $\begin{array}{l}\text { (a) Attraction } \\
\text { (b) Atraction }\end{array}$ & $\begin{array}{l}\text { Two-arm olfactometer with active airflow (R.xylophagorum); } \\
\text { Flight tunnel olfactometer with active airflow (S. pallidus); } \\
1 \text { female individual tested per run } \\
\text { test against control (clean air, uninfected pine bold) }\end{array}$ & Sullivan \& Berisford (2004) \\
\hline $\begin{array}{l}\text { Predators \& parasitoids } \\
\text { of Ips pini }\end{array}$ & $\begin{array}{l}\text { Hymenoptera } \\
\text { Diptera }\end{array}$ & $\begin{array}{l}\text { (a) Ophiostoma ips } \\
\text { (b) Pichia scolyti }\end{array}$ & $\begin{array}{l}\text { (a) Attraction of parasitoid Hymenoptera, predacious Diptera } \\
\text { (b) Attraction of predacious Diptera }\end{array}$ & Sticky field traps & Boone et al. (2008) \\
\hline $\begin{array}{l}\text { Vespula pensylvanica } \\
\text { Vespula germanica } \\
\text { (predacious) }\end{array}$ & Hymenoptera & $\begin{array}{l}\text { (a) Aureobasidium pullulans } \\
\text { voCs identified from A. pullulans: } \\
\text { (b) 2-methyl-1-butanol } \\
\text { (c) 3-methyl-1-butanol } \\
\text { (d) 2-phenylethanol } \\
\text { (e) Blend: (b) + (c) + (d) (51:39:10\% ratio) }\end{array}$ & $\begin{array}{l}\text { (a) Attraction of wasps, mainly Vespula pensylvanica \& } \\
\text { V. germanica } \\
\text { (b) Attraction } \\
\text { (c) Attraction, less compared to (b), (e) } \\
\text { (d) n.r. } \\
\text { (e) Attraction }\end{array}$ & Field traps; comparison against control (medium, blank) & Davis et al. (2012) \\
\hline $\begin{array}{l}\text { Prorops nasuta } \\
\text { (parasitoid of Hypothenemus } \\
\text { hampei) }\end{array}$ & Hymenoptera & $\begin{array}{l}\text { voCs identified from fungal infected dust/frass of } H \text {. hampei: } \\
\text { (a) 1-octen-3-ol } \\
\text { (b) 3-octanone }\end{array}$ & $\begin{array}{l}\text { (a) n.r. } \\
\text { (b) Attraction }\end{array}$ & $\begin{array}{l}\text { Two-arm olfactometer; test against control (clean air); } \\
1 \text { female individual tested per run }\end{array}$ & Román-Ruíz et al. (2012) \\
\hline $\begin{array}{l}\text { Ibalia leucospoides } \\
\text { (parasitoid of Sirex noctilio) }\end{array}$ & Hymenoptera & Amylostereum areolatum & $\begin{array}{l}\text { Attraction to } 14 \text { day-old } A \text {. areolatum; } \\
\text { n.r. to } 5,10,17,21,24,30 \text { day-old } A \text {. areolatum }\end{array}$ & $\begin{array}{l}\text { Two-arm olfactometer; } \\
1 \text { female individual tested per run; } \\
\text { test against control (medium: malt-yeast-pine extract agar) }\end{array}$ & Jofré et al. (2016) \\
\hline
\end{tabular}




\section{REFERENCES}

Auclerc A, Libourel PA, Salmon S, Bels V, and Ponge JF, 2010. Assessment of movement patterns in Folsomia candida (Hexapoda: Collembola) in the presence of food. Soil Biology and Biochemistry, 42(4):657-659. ISSN 00380717. doi:10.1016/j.soilbio.2009.12.012.

Azeem M, Rajarao GK, Nordenhem H, Nordlander G, and Borg-Karlson AK, 2013. Penicillium expansum volatiles reduce pine weevil attraction to host plants. Journal of Chemical Ecology, 39(1):120-128. ISSN 1573-1561. doi:10.1007/s10886-012-0232-5.

Becher PG, Bengtsson M, Hansson BS, and Witzgall P, 2010. Flying the fly: long-range flight behavior of Drosophila melanogaster to attractive odors. Journal of Chemical Ecology, 36(6):599-607. doi:10.1007/s10886-010-9794-2.

Becher PG, Flick G, Rozpędowska E, Schmidt A, Hagman A, Lebreton S, Larsson MC, Hansson BS, Piškur J, Witzgall P, and Bengtsson M, 2012. Yeast, not fruit volatiles mediate Drosophila melanogaster attraction, oviposition and development. Functional Ecology, 26(4):822-828. ISSN 02698463. doi:10.1111/j.1365-2435.2012.02006.x.

Belmain SR, Simmonds MSJ, and Blaney WM, 2002. Influence of odor from wood-decaying fungi on host selection behavior of deathwatch beetle, Xestobium rufovillosum. Journal of Chemical Ecology, 28(4):741-754. ISSN 00980331. doi:10.1023/A:1015284625697.

Bengtsson G, Erlandsson A, and Rundgren S, 1988. Fungal odour attracts soil Collembola. Soil Biology and Biochemistry, 20(1):25-30. ISSN 00380717. doi:10.1016/0038-0717(88) 90122-8.

Bengtsson G, Hedlund K, and Rundgren S, 1991. Selective odor perception in the soil Collembola Onychiurus armatus. Journal of Chemical Ecology, 17(11):2113-2125. doi: 10.1007/BF00987995.

Bengtsson G, Hedlund K, and Rundgren S, 1994. Food- and density-dependent dispersal: evidence from a soil collembolan. Journal of Animal Ecology, 63(3):513-520. doi:10.2307/ 5218.

Blackmer JL and Phelan PL, 1991. Effect of physiological state and fungal inoculation on chemically modulated host-plant finding by Carpophilus hemipterus and Carpophilus lugubris. Entomologia Experimentalis et Applicata, 61(1):33-43. ISSN 15707458. doi: 10.1111/j.1570-7458.1991.tb02393.x.

Boone CK, Six DL, Zheng Y, and Raffa KF, 2008. Parasitoids and dipteran predators exploit volatiles from microbial symbionts to locate bark beetles. Environmental Entomology, 37(1):150-161. ISSN 0046-225X. doi:10.1093/ee/37.1.150.

Brückner A, Schuster R, Smit T, Pollierer MM, Schäffler I, and Heethoff M, 2018. Track the snack - olfactory cues shape foraging behaviour of decomposing soil mites (Oribatida). Pedobiologia, 66:74-80. ISSN 00314056. doi:10.1016/j.pedobi.2017.10.004.

Buser CC, Newcomb RD, Gaskett AC, and Goddard MR, 2014. Niche construction initiates the evolution of mutualistic interactions. Ecology Letters, 17(10):1257-1264. ISSN 14610248. doi:10.1111/ele.12331. 
Chen G, Zhang RR, Liu Y, and Sun WB, 2014. Spore dispersal of fetid Lysurus mokusin by feces of mycophagous insects. Journal of Chemical Ecology, 40(8):893-899. ISSN 15731561. doi:10.1007/s10886-014-0481-6.

Cloonan KR, Andreadis SS, and Baker TC, 2016a. Attraction of female fungus gnats, Lycoriella ingenua, to mushroom-growing substrates and the green mold Trichoderma aggressivum. Entomologia Experimentalis et Applicata, 159(3):298-304. ISSN 15707458. doi: 10.1111/eea.12439.

Cloonan KR, Andreadis SS, Chen H, Jenkins NE, and Baker TC, 2016b. Attraction, oviposition and larval survival of the fungus gnat, Lycoriella ingenua, on fungal species isolated from adults, larvae, and mushroom compost. PLoS ONE, 11(12):1-18. ISSN 19326203. doi:10.1371/journal.pone.0167074.

Cotes B, Rännbäck LM, Björkman M, Norli HR, Meyling NV, Rämert B, and Anderson $\mathrm{P}, 2015$. Habitat selection of a parasitoid mediated by volatiles informing on host and intraguild predator densities. Oecologia, 179(1):151-162. ISSN 00298549. doi:10.1007/ s00442-015-3326-2.

Crowther TW, Boddy L, and Hefin Jones T, 2012. Functional and ecological consequences of saprotrophic fungus-grazer interactions. The ISME Journal, 6(11):1992-2001. ISSN 17517370. doi:10.1038/ismej.2012.53.

Crowther TW, Boddy L, and Jones TH, 2011a. Outcomes of fungal interactions are determined by soil invertebrate grazers. Ecology Letters, 14(11):1134-1142. ISSN 1461023X. doi:10.1111/j.1461-0248.2011.01682.x.

Crowther TW, Boddy L, and Jones TH, 2011b. Species-specific effects of soil fauna on fungal foraging and decomposition. Oecologia, 167(2):535-545. ISSN 00298549. doi:10.1007/ s00442-011-2005-1.

Crowther TW, Stanton DWG, Thomas SM, A'Bear AD, Hiscox J, Jones TH, Vorísková J, Baldrian P, and Boddy L, 2013. Top-down control of soil fungal community composition by a globally distributed keystone consumer. Ecology, 94(11):2518-2528. doi: 10.1890/13-0197.1.

Davis TS, Boundy-Mills K, and Landolt PJ, 2012. Volatile emissions from an epiphytic fungus are semiochemicals for eusocial wasps. Microbial Ecology, 64(4):1056-1063. ISSN 00953628. doi:10.1007/s00248-012-0074-2.

Dicke M, Van Lenteren JC, Boskamp GJF, and van Dongen-van Leeuwen E, 1984. Chemical stimuli in host-habitat location by Leptopilina heterotoma (Thomson) (Hymenoptera: Eucoilidae), a parasite of Drosophila. Journal of Chemical Ecology, 10(5):695-712. ISSN 00980331. doi:10.1007/BF00988537.

Dobzhansky T, Cooper DM, Phaff HJ, Knapp EP, and Carson HL, 1956. Differential attraction of species of Drosophila to different species of yeasts. Ecology, 37(3):544-550. doi: $10.2307 / 1930178$.

Drilling K and Dettner K, 2009. Electrophysiological responses of four fungivorous coleoptera to volatiles of Trametes versicolor: implications for host selection. Chemoecology, 19(2):109-115. ISSN 09377409. doi:10.1007/s00049-009-0015-9. 
Fäldt J, Jonsell M, Nordlander G, and Borg-Karlson AK, 1999. Volatiles of bracket fungi Fomitopsis pinicola and Fomes fomentarius and their functions as insect attractants. Journal of Chemical Ecology, 25(3):567-590. doi:10.1023/A:1020958005023.

Fischer C, Trautman EP, Crawford JM, Stabb EV, Handelsman J, and Broderick NA, 2017. Metabolite exchange between microbiome members produces compounds that influence Drosophila behavior. eLife, 6:1-25. ISSN 2050-084X. doi:10.7554/eLife.18855.

Ganter PF, 1988. The vectoring of cactophilic yeasts by Drosophila. Oecologia, 75(3):400-404. ISSN 00298549. doi:10.1007/BF00376943.

Gilbert DG, 1980. Dispersal of yeasts and bacteria by Drosophilia in a temperate forest. Oecologia, 46(1):135-137. ISSN 00298549. doi:10.1007/BF00346979.

Gloer JB, 1995. The chemistry of fungal antagonism and defense. Canadian Journal of Botany, 73(S1):1265-1274. doi:10.1139/b95-387.

Guevara R, Hutcheson KA, Mee AC, Rayner ADM, and Reynolds SE, 2000a. Resource partitioning of the host fungus Coriolus versicolor by two ciid beetles: the role of odour compounds and host ageing. Oikos, 91(1):184-194. ISSN 00301299. doi:10.1034/j.1600-0706. 2000.910118.x.

Guevara R, Rayner ADM, and Reynolds SE, 2000b. Orientation of specialist and generalist fungivorous ciid beetles to host and non-host odours. Physiological Entomology, 25(3):288295. ISSN 0307-6962. doi:10.1046/j.1365-3032.2000.00194.x.

Hall M and Hedlund K, 1999. The predatory mite Hypoaspis aculeifer is attracted to food of its fungivorous prey. Pedobiologia, 43(1):11-17.

Hanski I, 1989. Fungivory: fungi, insects and ecology. In N Wilding, N Collins, P Hammond, and J Webber, editors, Insect-fungus interactions, pages 25-68. Academic Press, London.

Hedlund K, Bengtsson G, and Rundgren S, 1995. Fungal odour discrimination in two sympatric species of fungivorous collembolans. Functional Ecology, 9(6):869-875. ISSN 02698463. doi:10.2307/2389984.

Holighaus $\mathrm{G}$ and Rohlfs M, 2018. Volatile and non-volatile fungal oxylipins in fungus invertebrate interactions. Fungal Ecology (in press). doi:10.1016/j.funeco.2018.09.005.

Holighaus G, Weißbecker B, von Fragstein M, and Schütz S, 2014. Ubiquitous eight-carbon volatiles of fungi are infochemicals for a specialist fungivore. Chemoecology, 24(2):57-66. ISSN 09377409. doi:10.1007/s00049-014-0151-8.

Hsueh YP, Gronquist MR, Schwarz EM, Nath RD, Lee CH, Gharib S, Schroeder FC, and Sternberg PW, 2017. Nematophagous fungus Arthrobotrys oligospora mimics olfactory cues of sex and food to lure its nematode prey. eLife, 6:1-21. ISSN 2050084X. doi:10.7554/eLife. 20023.

Hulcr J, Mann R, and Stelinski LL, 2011. The scent of a partner: ambrosia beetles are attracted to volatiles from their fungal symbionts. Journal of Chemical Ecology, 37(12):1374-1377. ISSN 00980331. doi:10.1007/s10886-011-0046-x. 
Hussain A, Tian MY, He YR, Bland JM, and Gu WX, 2010. Behavioral and electrophysiological responses of Coptotermes formosanus Shiraki towards entomopathogenic fungal volatiles. Biological Control, 55(3):166-173. ISSN 10499644. doi:10.1016/j.biocontrol.2010. 08.009 .

Jofré N, Pildain MB, Cirigliano AM, Cabrera GM, Corley JC, and Martínez AS, 2016. Host selection by Ibalia leucospoides based on temporal variations of volatiles from the hosts' fungal symbiont. Journal of Applied Entomology, 140(10):736-743. ISSN 14390418. doi: 10.1111/jen.12313.

Jonsell M and Nordlander G, 1995. Field attraction of Coleoptera to odours of the wooddecaying polypores Fomitopsis pinicola and Fomes fomentarius. Annales Zoologici Fennici, 32(4):391-402. ISSN 0003455X (ISSN).

Jonsell M, Schroeder M, and Larsson Jonsell T, 2003. The saproxylic beetle Bolitophagus reticulatus: its frequency in managed forests, attraction to volatiles and flight period. Ecography, 26(26):421-428. ISSN 09067590. doi:10.1034/j.1600-0587.2003.03449.x.

Koban MB, Gossner MM, Müller J, Steidle JLM, Bässler C, Hothorn T, Unsicker SB, and Seibold S, 2016. Short-distance attraction of saproxylic Heteroptera to olfactory cues. Insect Conservation and Diversity, 9(3):254-257. ISSN 17524598. doi:10.1111/icad.12161.

Korpi A, Jarnberg J, and Pasanen AL, 2009. Microbial volatile organic compounds. Critical Reviews in Toxicology, 39(2):139-193. ISSN 1040-8444. doi:10.1080/10408440802291497.

Lam K, Tsang M, Labrie A, Gries R, and Gries G, 2010. Semiochemical-mediated oviposition avoidance by female house flies, Musca domestica, on animal feces colonized with harmful fungi. Journal of Chemical Ecology, 36(2):141-147. ISSN 00980331. doi: 10.1007/s10886-010-9741-2.

Lin F, Ye J, Wang H, Zhang A, and Zhao B, 2013. Host deception: predaceous fungus, Esteya vermicola, entices pine wood nematode by mimicking the scent of pine tree for nutrient. PloS one, 8(8):e71676. ISSN 1932-6203. doi:10.1371/journal.pone.0071676.

Lin H and Phelan PL, 1991. Identification of food volatiles attractive to dusky sap beetle, Capophilus lugubris (Coleoptera: Nitidulidae). Journal of Chemical Ecology, 17(6):1273-1286. doi:10.1007/BF01402949.

Lin H and Phelan PL, 1992. Comparison of volatiles from beetle-transmitted Ceraocystis fagacearum and four non-insect-dependent fungi. Journal of Chemical Ecology, 18(9):16231632. doi:10.1007/BF00993234.

Madden AA, Epps MJ, Fukami T, Irwin RE, Sheppard J, Sorger DM, and Dunn RR, 2018. The ecology of insect-yeast relationships and its relevance to human industry. Proceedings of the Royal Society B: Biological Sciences, 285(1875):20172733. ISSN 0962-8452. doi:10.1098/ rspb.2017.2733.

Madden JL, 1968. Behavioural responses of parasites to the symbiotic fungus associated with Sirex noctilio F. Nature, 218:189-190. ISSN 0028-0836. doi:10.1038/218189a0.

Mburu DM, Maniania NK, and Hassanali A, 2013. Comparison of volatile blends and nucleotide sequences of two Beauveria bassiana isolates of different virulence and repellency towards the termite Macrotermes michealseni. Journal of Chemical Ecology, 39(1):101-108. ISSN 00980331. doi:10.1007/s10886-012-0207-6. 
Mburu DM, Ndung'u MW, Maniania NK, and Hassanali A, 2011. Comparison of volatile blends and gene sequences of two isolates of Metarhizium anisopliae of different virulence and repellency toward the termite Macrotermes michaelseni. Journal of Experimental Biology, 214(6):956-962. ISSN 0022-0949. doi:10.1242/jeb.050419.

Mburu DM, Ochola L, Maniania NK, Njagi PGN, Gitonga LM, Ndung'u MW, Wanjoya AK, and Hassanali A, 2009. Relationship between virulence and repellency of entomopathogenic isolates of Metarhizium anisopliae and Beauveria bassiana to the termite Macrotermes michaelseni. Journal of Insect Physiology, 55(9):774-780. ISSN 00221910. doi: 10.1016/j.jinsphys.2009.04.015.

Mondy N, Pracros P, Fermaud M, and Corio-Costet MF, 1998. Olfactory and gustatory behaviour by larvae of Lobesia botrana in response to Botrytis cinerea. Entomologia Experimentalis et Applicata, 88(1):1-7. ISSN 00138703. doi:10.1023/A:1003286931364.

Morath SU, Hung R, and Bennett JW, 2012. Fungal volatile organic compounds: a review with emphasis on their biotechnological potential. Fungal Biology Reviews, 26(2-3):73-83. ISSN 17494613. doi:10.1016/j.fbr.2012.07.001.

Münch D and Galizia CG, 2016. DoOR 2.0 - Comprehensive mapping of Drosophila melanogaster odorant responses. Scientific Reports, 6(October 2015):1-14. ISSN 20452322. doi:10.1038/srep21841.

Nout MJR and Bartelt RJ, 1998. Attraction of a flying nitidulid (Carpophilus humeralis) to volatiles produced by yeasts grown on sweet corn and a corn-based medium. Journal of Chemical Ecology, 24(7):1217-1239. doi:10.1023/A:1022451020013.

Ormond EL, Thomas APM, Pell JK, Freeman SN, and Roy HE, 2011. Avoidance of a generalist entomopathogenic fungus by the ladybird, Coccinella septempunctata. FEMS Microbiology Ecology, 77(2):229-237. ISSN 01686496. doi:10.1111/j.1574-6941.2011.01100.x.

Pacioni G, Bologna MA, and Laurenzi M, 1991. Insect attraction by tuber: a chemical explanation. Mycological Research, 95(12):1359-1363. ISSN 09537562. doi:10.1016/ S0953-7562(09)80385-7.

Palanca L, Gaskett AC, Günther CS, Newcomb RD, and Goddard MR, 2013. Quantifying variation in the ability of yeasts to attract Drosophila melanogaster. PLoS ONE, 8(9):1-10. doi:10.1371/journal.pone.0075332.

Pfeffer SP and Filser J, 2010. Attraction to prey and prey-associated odours by the predatory mite Hypoaspis aculeifer in a soil experimental system. Soil Biology and Biochemistry, 42(8):1355-1357. ISSN 00380717. doi:10.1016/j.soilbio.2010.03.018.

Pfeil R and Mumma R, 1993. Bioassay for evaluating attraction of the phorid fly, Megaselia halterata to compost colonised by the commercial mushroom, Agaricus bisporus and to 1octen-3-ol and 3-octanone. Entomologia Experimentalis et Applicata, 69:137-144. doi:10. 1111/j.1570-7458.1993.tb01736.x.

Phelan PL and Lin H, 1991. Chemical characterization of fruit and fungal volatiles attractive to dried-fruit beetle, Carpophilus hemipterus (L.) (Coleoptera: Nitidulidae). Journal of Chemical Ecology, 17(6):1253-1272. doi:10.1007/BF01402948. 
Pierce AM, Pierce HD, Borden JH, and Oehlschlager AC, 1991. Fungal volatiles: semiochemicals for stored-product beetles (Coleoptera: Cucujidae). Journal of Chemical Ecology, 17(3):581-597. ISSN 00980331. doi:10.1007/BF00982128.

Rashki MR and Hirvani AS, 2013. The effect of entomopathogenic fungus, Beauveria bassiana on life table parameters and behavioural response of Aphis gossypii. Bulletin of Insectology, 66(1):85-91.

Rizvi SZM, Raman A, Wheatley WM, and Cook G, 2016. Oviposition preference and larval performance of Epiphyas postvittana (Lepidoptera: Tortricidae) on Botrytis cinerea (Helotiales: Sclerotiniaceae) infected berries of Vitis vinifera (Vitales: Vitaceae). Insect Science, 23(2):313-325. ISSN 17447917. doi:10.1111/1744-7917.12191.

Rohlfs M, 2015. Fungal secondary metabolite dynamics in fungus-grazer interactions: novel insights and unanswered questions. Frontiers in Microbiology, 6(JAN):1-5. ISSN 1664302X. doi:10.3389/fmicb.2014.00788.

Román-Ruíz AK, Malo EA, Huerta G, Castillo A, Barrera JF, and Rojas JC, 2012. Identification and origin of host-associated volatiles attractive to Prorops nasuta, a parasitoid of the coffee berry borer. Arthropod-Plant Interactions, 6(4):611-620. ISSN 18728855. doi: 10.1007/s11829-012-9197-0.

Rosengaus R, Guldin M, and Traniello J, 1998a. Inhibitory effect of termite fecal pellets on fungal spore germination. Journal of Chemical Ecology, 24(10):1697-1706. ISSN 0098-0331. doi:10.1023/A:1020872729671.

Rosengaus RB, Jordan C, Lefebvre ML, and Traniello JFA, 1999. Pathogen alarm behavior in a termite: a new form of communication in social insects. Naturwissenschaften, 86(11):544548. ISSN 00281042. doi:10.1007/s001140050672.

Rosengaus RB, Maxmen AB, Coates LE, and Traniello JF, 1998b. Disease resistance: a benefit of sociality in the dampwood termite Zootermopsis angusticollis (Isoptera: Termopsidae). Behavioral Ecology and Sociobiology, 44(2):125-134. ISSN 03405443. doi: $10.1007 / \mathrm{s} 002650050523$.

Sadaka-Laulan N, Ponge JF, Roquebert MF, Bury E, and Boumezzough A, 1998. Feeding preferences of the collembolan Onychiurus sinensis for fungi colonizing holm oak litter (Quercus rotundifolia Lam.). European Journal of Soil Biology, 34(4):179-188. ISSN 11645563. doi:10.1016/S1164-5563(00)86660-1.

Sarvary MA, Hajek AE, Böröczky K, Raguso RA, and Cooperband MF, 2016. Investigating the effects of symbiotic fungi on the flight behaviour of Sirex noctilio (Hymenoptera: Siricidae). The Canadian Entomologist, 9:1-9. ISSN 0008-347X. doi:10.4039/tce.2016.10.

Sawahata T, Shimano S, and Suzuki M, 2008. Tricholoma matsutake 1-Ocen-3-ol and methyl cinnamate repel mycophagous Proisotoma minuta (Collembola: Insecta). Mycorrhiza, 18(2):111-114. ISSN 09406360. doi:10.1007/s00572-007-0158-x.

Scheidler NH, Liu C, Hamby KA, Zalom FG, and Syed Z, 2015. Volatile codes: correlation of olfactory signals and reception in Drosophila-yeast chemical communication. Scientific Reports, 5(April):14059. ISSN 2045-2322. doi:10.1038/srep14059. 
Scheu S and Simmerling F, 2004. Growth and reproduction of fungal feeding Collembola as affected by fungal species, melanin and mixed diets. Oecologia, 139(3):347-353. ISSN 00298549. doi:10.1007/s00442-004-1513-7.

Schiestl FP, Steinebrunner F, Schulz C, von Reuss S, Francke W, Weymuth C, and Leuchtmann A, 2006. Evolution of 'pollinator'- attracting signals in fungi. Biology Letters, 2(3):401-4. ISSN 1744-9561. doi:10.1098/rsbl.2006.0479.

Schoonhoven LM, van Loon JJA, and Dicke M, 2005. Insect-plant biology. Oxford University Press, New York, 2 edition. ISBN 978-0-19-852594-3.

Staaden S, Milcu A, Rohlfs M, and Scheu S, 2011. Olfactory cues associated with fungal grazing intensity and secondary metabolite pathway modulate Collembola foraging behaviour. Soil Biology and Biochemistry, 43(7):1411-1416. ISSN 00380717. doi: 10.1016/j.soilbio.2010.10.002.

Stamps Ja, Yang LH, Morales VM, and Boundy-Mills KL, 2012. Drosophila regulate yeast density and increase yeast community similarity in a natural substrate. PloS ONE, 7(7):e42238. ISSN 1932-6203. doi:10.1371/journal.pone.0042238.

Starmer WT, Peris F, and Fontdevila A, 1988. The transmission of yeasts by Drosophila buzzatii during courtship and mating. Animal Behaviour, 36(6):1691-1695. ISSN 00033472. doi:10.1016/S0003-3472(88)80109-X.

Steinebrunner F, Schiestl FP, and Leuchtmann A, 2008a. Ecological role of volatiles produced by Epichloë: differences in antifungal toxicity. FEMS Microbiology Ecology, 64(2):307-316. ISSN 01686496. doi:10.1111/j.1574-6941.2008.00452.x.

Steinebrunner F, Twele R, Francke W, Leuchtmann A, and Schiestl FP, 2008b. Role of odour compounds in the attraction of gamete vectors in endophytic Epichloë fungi. The New Phytologist, 178(2):401-11. ISSN 1469-8137. doi:10.1111/j.1469-8137.2007.02347.x.

Steiner S, Erdmann D, Steidle JLM, and Ruther J, 2007. Host habitat assessment by a parasitoid using fungal volatiles. Frontiers in Zoology, 4:3. ISSN 1742-9994. doi: 10.1186/1742-9994-4-3.

Stötefeld L, Holighaus G, Schütz S, and Rohlfs M, 2015. Volatile-mediated location of mutualist host and toxic non-host microfungi by Drosophila larvae. Chemoecology, 25(5):271-283. ISSN 09377409. doi:10.1007/s00049-015-0197-2.

Sullivan BT and Berisford CW, 2004. Semiochemicals from fungal associates of bark beetles may mediate host location behavior of parasitoids. Journal of Chemical Ecology, 30(4):703717. ISSN 00980331. doi:10.1023/B:JOEC.0000028426.37482.17.

Tabata J, de Moraes CM, and Mescher MC, 2011. Olfactory cues from plants infected by powdery mildew guide foraging by a mycophagous ladybird beetle. PLoS ONE, 6(8):2-7. ISSN 19326203. doi:10.1371/journal.pone.0023799.

Tasin M, Betta E, Carlin S, Gasperi F, Mattivi F, and Pertot I, 2011. Volatiles that encode hostplant quality in the grapevine moth. Phytochemistry, 72(16):1999-2005. ISSN 00319422. doi:10.1016/j.phytochem.2011.06.006. 
Tasin M, Knudsen GK, and Pertot I, 2012. Smelling a diseased host: grapevine moth responses to healthy and fungus-infected grapes. Animal Behaviour, 83(2):555-562. ISSN 00033472. doi:10.1016/j.anbehav.2011.12.003.

Thakeow P, Angeli S, Weissbecker B, and Schütz S, 2008. Antennal and behavioral responses of Cis boleti to fungal odor of Trametes gibbosa. Chemical Senses, 33(4):379-87. ISSN 14643553. doi:10.1093/chemse/bjn005.

Vanhaelen M, Vanhaelen-Fastré R, and Geeraerts J, 1980. Occurrence in mushrooms (Homobasidiomycetes) of cis- and trans-octa-1,5-dien-3-ol, attractants to the cheese mite Tyrophagus putrescentiae (Schrank) (Acarina, Acaridae). Experientia, 36:406-407. doi: 10.1007/BF01975114.

Vega FE and Blackwell M, 2005. Insect - fungal associations: ecology and evolution. Oxford University Press, New York. ISBN 0195166523.

Vet LEM, Janse C, van Achterberg C, and van Alphen JJM, 1984. Microhabitat location and niche segregation in two sibling species of Drosophilid parasitoids: Asobara tabida (Nees) and A. rufescens (Foerster) (Braconidae: Alysiinae). Oecologia, 61(2):182-188. ISSN 00298549. doi:10.1007/BF00396757.

Witzgall P, Proffit M, Rozpedowska E, Becher PG, Andreadis S, Coracini M, Lindblom TUT, Ream LJ, Hagman A, Bengtsson M, Kurtzman CP, Piskur J, and Knight A, 2012. "This is not an apple"-yeast mutualism in codling moth. Journal of Chemical Ecology, 38(8):949-957. ISSN 00980331. doi:10.1007/s10886-012-0158-y.

Wood WF, Archer CL, and Largent DL, 2001. 1-Octen-3-ol, a banana slug antifeedant from mushrooms. Biochemical Systematics and Ecology, 29(5):531-533. ISSN 03051978. doi:10. 1016/S0305-1978(00)00076-4.

Yanagawa A, Fujiwara-Tsujii N, Akino T, Yoshimura T, Shimizu S, and Shimizu S, 2011. Musty odor of entomopathogens enhances disease-prevention behaviors in the termite Coptotermes formosanus. Journal of Invertebrate Pathology, 108(1):1-6. doi:10.1016/j.jip.2011. 06.001 .

Yanagawa A, Fujiwara-Tsujii N, Akino T, Yoshimura T, Yanagawa T, and Shimizu S, 2012. Odor aversion and pathogen-removal efficiency in grooming behavior of the termite Coptotermes formosanus. PLoS ONE, 7(10):1-9. ISSN 19326203. doi:10.1371/journal.pone. 0047412 .

Yanagawa A, Imai T, Akino T, Toh Y, and Yoshimura T, 2015. Olfactory cues from pathogenic fungus affect the direction of motion of termites, Coptotermes formosanus. Journal of Chemical Ecology, 41(12):1118-1126. ISSN 15731561. doi:10.1007/s10886-015-0649-8.

Yang S, Mei XD, Zhang XF, Li YF, She D, Zhang T, and Ning J, 2017. Attraction of coffee bean weevil, Araecerus fasciculatus, to volatiles from the industrial yeast Kluyveromyces lactis. Journal of Chemical Ecology, 43(2):180-187. ISSN 15731561. doi:10.1007/s10886-016-0809-5.

Zidar P, Kaschl U, Drobne D, Bozic J, and Strus J, 2003. Behavioural responses in paired food choice experiments with Oniscus asellus (Crustacea, Isopoda) as an indicator of different food quality. Arhiv Za Higijenu Rada I Toksikologiju, 54:177-181. 
Zimmer M, Kautz G, and Topp W, 1996. Olfaction in terrestrial isopods (Crustacea: Oniscidea): responses of Porcellio scaber to the odour of litter. European Journal of Soil Biology, 32(3):141-147.

Zirbes L, Mescher M, Vrancken V, Wathelet JP, Verheggen FJ, Thonart P, and Haubruge E, 2011. Earthworms use odor cues to locate and feed on microorganisms in soil. PLoS ONE, 6(7):1-7. ISSN 19326203. doi:10.1371/journal.pone.0021927. 


\section{Subject of The PRESENT PhD PROJECT}

A major challenge in terrestrial ecology is to understand the mechanisms underlying patterns of variation in foraging and feeding decisions of fungivorous soil arthropods, and hence how particular fungi are affected by grazers and vice versa. Increasing experimental evidence suggests a significant role of fungal volatiles, especially oxylipins, in shaping the foraging behaviour of fungivorous arthropods (Chapter 1, however, a direct link between the obvious dynamics in fungal volatile formation and the behaviours underlying arthropod foraging and feeding decisions has not yet been established. To gain more general insights into the chemical ecology of fungus-arthropod interactions, I analyse fungal volatile profiles by means of gas chromatography-mass spectrometry and observe behavioural responses of different Collembola species and isopods by focussing on both the searching and contact phase of the food selection process to characterise the mode of action of fungal volatiles, oxylipins in particular, as attractants, repellents, arrestants, deterrents and/or phagostimulants. By combining fungal chemistry and arthropod behaviour, I expect to provide important hints for a better understanding of the mechanisms that regulate the location of fungal food sources in Collembola and isopods, both major groups of facultative fungivores in decomposer systems.

Hypothesis 1: Based on the presumption that oxylipin volatiles are ubiquitous in soil systems, derived from the fact that the wound-activated emission of oxylipins is a conserved mechanism in higher fungi, I hypothesise that oxylipin volatiles function as food-finding cues for soil animals by acting as attractants, arrestants, and/or phagostimulants.

Hypothesis 2: Unicellular yeasts and filamentous fungi differ in their volatile emissions and Collembola are able to use characteristics in volatile profiles to differentiate between suitable and less suitable fungal species. In particular I expect that volatile-mediated attraction to or avoidance of fungal colonies during the searching phase are reflected in the acceptance or rejection of fungi during the contact phase and finally in an increased or reduced growth and reproduction of Collembola when fungi are given as single diets. 


\section{CHAPTER}

\section{WOUND-ACTIVATED FUNGAL OXYLIPIN VOLATILES FUNCTION AS INFOCHEMICALS FOR COLLEMBOLA}

\subsection{Abstract}

Fungivorous arthropods have been suggested to use fungal volatiles and in particular oxylipins as infochemicals to make adaptive foraging and feeding decisions in a similar way to herbivores. Fungal tissue wounding is well known to activate the emission of volatile oxylipin compounds, however, the effect of wounding-related chemical variation on the foraging behaviour of fungivorous soil arthropods is largely unknown and therefore represents the main issue of this study. Using a direct observation approach, I linked behavioural responses of individual Collembola (Folsomia candida, Sinella curviseta, Heteromurus nitidus) during the searching (food location) and contact phase (food acceptance) of food selection to woundactivated changes in the volatile profile of the dietary saprotrophic fungus Chaetomium globosum.

GC-MS analysis revealed a significant increase in headspace concentrations of the oxylipin volatiles 3-octanone and 3-octyl acetate in artificially wounded C. globosum colonies. Collembola movement patterns (volatile-mediated spatial foraging) were not affected by wounding, indicating that increased oxylipin emissions did not increase the attractivity of C. globosum colonies. In contrast, observation of feeding and contact behaviour revealed increased acceptance of wounded colonies as food source. Among the three tested species, the clearest response was observed in $H$. nitidus and F. candida; a significantly higher number of individuals fed on wounded colonies more rapidly and the mean duration of colony contacts was increased. Moreover, the proportion of time H. nitidus individuals spent with colonycontact and feeding was higher in the presence of wounded colonies. Higher acceptance of wounded colonies by S. curviseta is indicated by a lower number of colony contacts prior to the onset of feeding. In addition, the ability of the oxylipin compound 3-octanone to induce 
'substrate biting', a here newly described component of the Collembola foraging behaviour, was tested. The number of F. candida and S. curviseta individuals that showed 'substrate biting' behaviour increased with increasing 3-octanone concentration ( $\left.\mathrm{w} / \mathrm{w} 0-10^{-3}\right)$. I suggest that 'substrate biting' is a kind of exploratory behaviour that enables Collembola to test if fungal food is present, and can therefore be considered as 'test-biting' (probing).

Overall, the results strongly suggest that the wound-activated fungal oxylipin 3-octanone functions as food-finding cue and phagostimulant. Observed differences in behavioural responses of the three tested Collembola species are discussed in relation to species-specific resource use and species coexistence.

Keywords: Collembola, fungus-arthropod interaction, spatial foraging behaviour, attraction, arrestance, testbiting, phagostimulant, infochemicals, volatile organic compounds, wounding, oxylipins, 3-octanone, 3-methyl1-butanol

\subsection{INTRODUCTION}

The perception and use of volatile organic compounds as infochemicals is most relevant in enabling arthropods to locate suitable feeding and/or oviposition sites from a distance. $\mathrm{Nu}$ merous studies on plant-insect interactions have shown that volatiles, most notably oxylipins or 'green leaf volatiles', play a significant role in regulating host selection by herbivores (Ameye et al. 2017, Bruce et al. 2005). For example, plant volatile oxylipins have central function in a plant's defence response to herbivore grazing (Heil 2014) and are used as infochemicals by foraging insects to find their host plants (Bruce et al.2005).

A long-standing supposition is that fungivorous arthropods use fungal borne chemicals to make adaptive foraging and feeding decisions in similar ways to herbivores (e.g. Rohlfs and Churchill 2011, Speed et al. 2012), and fungal-derived volatiles are strongly suspected to play a role in mediating fungus-arthropod interactions. In particular, fungal volatile oxylipins, which can be considered as analogous to plant oxylipins due to a common synthesis pathway (Hernández-Oñate and Herrera-Estrella 2015, Tsitsigiannis and Keller 2007), are suggested to function as host cues, attractants, repellents, arrestants, stimulants or deterrents for fungivorous arthropods (Hanski 1989). Preferences of fungivorous arthropods for certain fungi base on characteristics in fungal volatile profiles (Bengtsson et al. 1991), 
and especially fungal volatile oxylipins have been demonstrated to influence fungivore foraging decisions by eliciting avoidance, attraction and/or arrestance (Bengtsson et al. 1991. Drilling and Dettner 2009, Fäldt et al. 1999, Holighaus et al. 2014, Pierce et al. 1991b, Sawahata et al. 2008, Tabata et al. 2011, Thakeow et al. 2008, Vanhaelen et al. 1980). Similar to plant oxylipins, fungal oxylipins are released in response to environmental stress, such as tissue wounding (Fäldt et al. 1999, Wurzenberger and Grosch 1983). As a consequence of their immobility, fungi are prey to a wide range of fungivorous soil animals and constantly exposed to mechanical feeding damage. There is direct and indirect evidence that artificial or grazer-mediated wounding of fungal tissue induces changes in the foraging behaviour of fungivorous soil arthropods (Döll et al. 2013). As every grazing event may have the potential to change the fungal volatile profile, facilitate food evaluation by the respective animal, and food-finding by other fungivorous soil animals moving in slightly further distance, the present study aims at directly linking foraging and feeding decisions to wounding-related variation in fungal volatile emissions using a direct observation approach.

According to Schoonhoven et al. (2005) the food selection process comprises two main phases, the searching phase followed by the contact phase, resulting in either acceptance or rejection of the potential food source. Whereas the searching behaviour is assumed to be exclusively driven by volatiles, additional visual and gustatory information may become relevant during the contact phase and could be used by foraging animals for the evaluation of a potential food source (Schoonhoven et al. 2005). To investigate foraging decisions with respect to these two phases of food selection, I chose a model system comprising Folsomia candida, Sinella curviseta, and Heteromurus nitidus Collembola, and the saprotrophic filamentous fungus Chaetomium globosum. Collembola are a well-known group of facultative fungivorous soil arthropods (Hopkin 1997) and have traditionally been used to investigate grazing preferences in soil animals (e.g. Bardgett et al. 1993, Heděnec et al. 2013, Hiol Hiol et al. 1994, Men'ko et al. 2006, Sadaka-Laulan et al. 1998, Visser and Whittaker 1977). Numerous short- and long-term choice experiments have shown that Collembola can be highly selective when foraging on saprotrophic fungi and are able to differentiate between fungal species (Bengtsson et al. 1991, Jørgensen et al. 2005, Maraun et al. 2003, Shaw 1988, Staaden et al. 2011). Preferences usually correlate positively with animal fitness measures (Chen et al. 1995, Heděnec et al. 2013, Rohlfs et al. 2007, Scheu and Simmerling 2004). Recent studies strongly suggest a significant role of variation in fungal secondary metabolite production in affecting the foraging behaviour and food choice of Collembola (Stötefeld et al.)2012, Yin et al. 2012). The use of fungal-derived volatiles by Collembola during spatial foraging has 
been demonstrated by Hedlund et al. (1995). To extend our knowledge on the mechanisms driving fungus-arthropod interactions, I investigate the effect of fungal tissue wounding on the food-finding ability (off-patch searching) and feeding decision (on-patch behaviour) of Collembola. As C. globosum is known to serve as dietary fungus for different invertebrate soil animals such as lumbricids (Maraun et al. 2003), isopods (Ihnen and Zimmer 2008, Rothe and Gleixner 2000) and Collembola (Haubert et al. 2011), I hypothesise that C. globosum-derived volatile oxylipins function as cues for Collembola and consequently, that a wound-activated increase in volatile oxylipins increase the attractiveness of $C$. globosum colonies for foraging Collembola. Hence, Collembola are expected to be more strongly attracted to and/or arrested by volatiles of wounded compared to unwounded C. globosum colonies and higher attractivity results in higher acceptance of respective colonies as food source.

\subsection{Material ANd Methods}

\subsubsection{Cultivation of Collembola And C. globosum}

Collembola, F. candida ('Berlin' strain), S. curviseta, and H. nitidus were cultured on a moistened mixture of plaster and activated charcoal (proportion 40:1) in Petri dishes (9 cm in diameter) with a vent in the lid that was covered with fine-mesh gauze. The lid was sealed with parafilm to prevent animals from escaping. Cultures were incubated at $20^{\circ} \mathrm{C}$ in constant darkness and fed with dried baker's yeast and/or freeze-dried stinging nettle powder once per week. Age synchronized populations were obtained by transferring adult individuals to new dishes for oviposition. After seven days adults were removed and eggs remained. For the experiments the Collembola were raised until the adult instar and their age at the time of experimental observation ranged between 60 and 90 days. Prior to the experiments the Collembola were starved for seven days. Fresh fungal colonies of $C$. globosum were obtained by cutting and transferring square pieces of fungal tissue $(3 \times 3 \mathrm{~mm})$ to sterilized malt-extract agar (MEA; recipe: $6 \mathrm{~g}$ of agar, $9 \mathrm{~g}$ of malt extract, $1.5 \mathrm{~g}$ of soy peptone, filled up to $300 \mathrm{ml}$ with $\mathrm{H}_{2} \mathrm{O}$ ) and incubation at $20^{\circ} \mathrm{C}$ in constant darkness. 


\subsubsection{SAMPLING, IDENTIFICATION, AND QUANTIFICATION OF C. globosum VOLATILES}

Volatile profiles of C. globosum were determined to find out whether fungal tissue wounding affects volatile emissions. C. globosum fungal colonies were grown for five days in glass tubes (150 $\mathrm{mm}$ in height, $30 \mathrm{~mm}$ in diameter) filled with $50 \mathrm{ml}$ MEA. The headspace solidphase microextraction technique (HS-SPME; fibre: $85 \mu \mathrm{m}$ CarboxenTM/ Polydimethylsiloxane StableFlexTM) (Pawliszyn 1997) was used to extract C. globosum volatiles from the fungal headspace at $20^{\circ} \mathrm{C}$ in darkness. Volatiles were collected from unwounded and wounded fungal colonies (8 replicates per treatment), and fungal-free MEA controls (4 replicates). Wounding of fungal colonies was done by standardized disruption of fungal tissue with a thin wire loop ( $3 \mathrm{~mm}$ in diameter) by scratching a mesh pattern (four horizontal and vertical scratches; approximately $50 \%$ of the fungal tissue was disrupted) exactly 30 minutes before the volatile extraction. After the wounding treatment glass tubes were sealed with parafilm, so that volatiles could accumulate for 30 minutes. Samples of unwounded C. globosum and MEA controls were treated in the same way except for the disruption of fungal tissue. The needle of the SPME device was carefully stuck through the parafilm into the glass tube and the fibre was exposed to the headspace over a period of 60 minutes. Volatile samples were successively analysed by using a gas chromatograph (GC; Agilent Technologies, 6890N; Palo Alto, USA) (non-polar HP-5ms column; 0.25 mm ID; 30 m length; 0.25 $\mu \mathrm{m}$ film thickness) coupled to a mass spectrometer (MS; Agilent Technologies, 5973N; Palo Alto, USA). The GC was programmed as follows: flow rate of $1.0 \mathrm{ml}$ per minute (Helium as carrier gas), initial oven temperature $-30{ }^{\circ} \mathrm{C}$ (cooled with liquid $\mathrm{N}_{2}$ ) for 1.5 minutes, temperature ramp $\left(6^{\circ} \mathrm{C}\right.$ minute- 1 up to $\left.200{ }^{\circ} \mathrm{C}\right)$, maintenance at $200{ }^{\circ} \mathrm{C}$ for 3 minutes. The MS recorded full scans of 20-345 amu with electron ionization at $70 \mathrm{eV}$. GC-MS data were analysed with MSD ChemStation Data Analysis software (Agilent Technologies; version D.02.00.275) and AMDIS (Geithersburg, MD; version 2.66). Tentative compound identification was done by comparing mass spectra of detected compounds with those of mass spectral libraries NIST 08 combined with Wiley 9, and GC retention values of target compounds were compared to literature values measured with similar GC parameters. After removing MEA-borne volatiles, three C. globosum-derived compounds were verified as 3octanone, 3-octyl acetate, and 3-methyl-1-butanol, by comparing GC retention values with those of authentic standards. For this purpose Van den Dool and Kratz retention indices were calculated from retention times of target compounds and retention times of n-alkanes (alkane standard solution series C8-C20) by using the Van den Dool and Kratz equation: 
$I_{x}=100 n+100\left(t_{x}-t_{n}\right) /\left(t_{n+1}-t_{n}\right)\left(t_{x}\right.$ : retention time of target compound; $t_{n}, t_{n+1}$ : retention times of two consecutive n-alkanes eluted immediately before and after $t_{x}$ ). Quantification of C. globosum-derived compounds was done by using manually integrated peak areas of compound characteristic ions and corresponding calibration curves for authentic compounds diluted with paraffin (3-octanone: $96 \%$, CAS: 106-68-3, Merck, Darmstadt, Germany; 3-octyl acetate: 98 \%, CAS: 4864-61-3, Sigma-Aldrich, St. Gallen, Switzerland; 3methyl-1-butanol: \%, CAS: 123-51-3, Sigma-Aldrich) (Appendix: Figure A.2.1). Headspace concentrations $\left(\mathrm{ng} / \mathrm{cm}^{3}\right)$ were calculated from peak areas and Antoine coefficients (component specific constants) by means of the Antoine equation (Yaws 2007).

\subsubsection{SELECTION OF VARIABLES FOR CHARACTERISATION OF COLLEMBOLA RESPONSES}

Three experiments were conducted to assess responses of Collembola with respect to the searching and the contact phase of food selection (Table 2.1) to test whether wounding of fungal tissue affects the foraging behaviour (food-finding and feeding decision) of Collembola. The selection of suitable experimental setups and variables based on preliminary experiments and direct behavioural observation. 
Table 2.1: Subject of the present study and overview on components of the food selection process (adapted from Dethier et al. (1960), Schoonhoven et al. (2005)). By assuming that C. globosum colonies emit volatiles that Collembola can use as cues for food selection, the volatile designations (third column) refer to behavioural responses of Collembola characterised by the measured variables (second column).

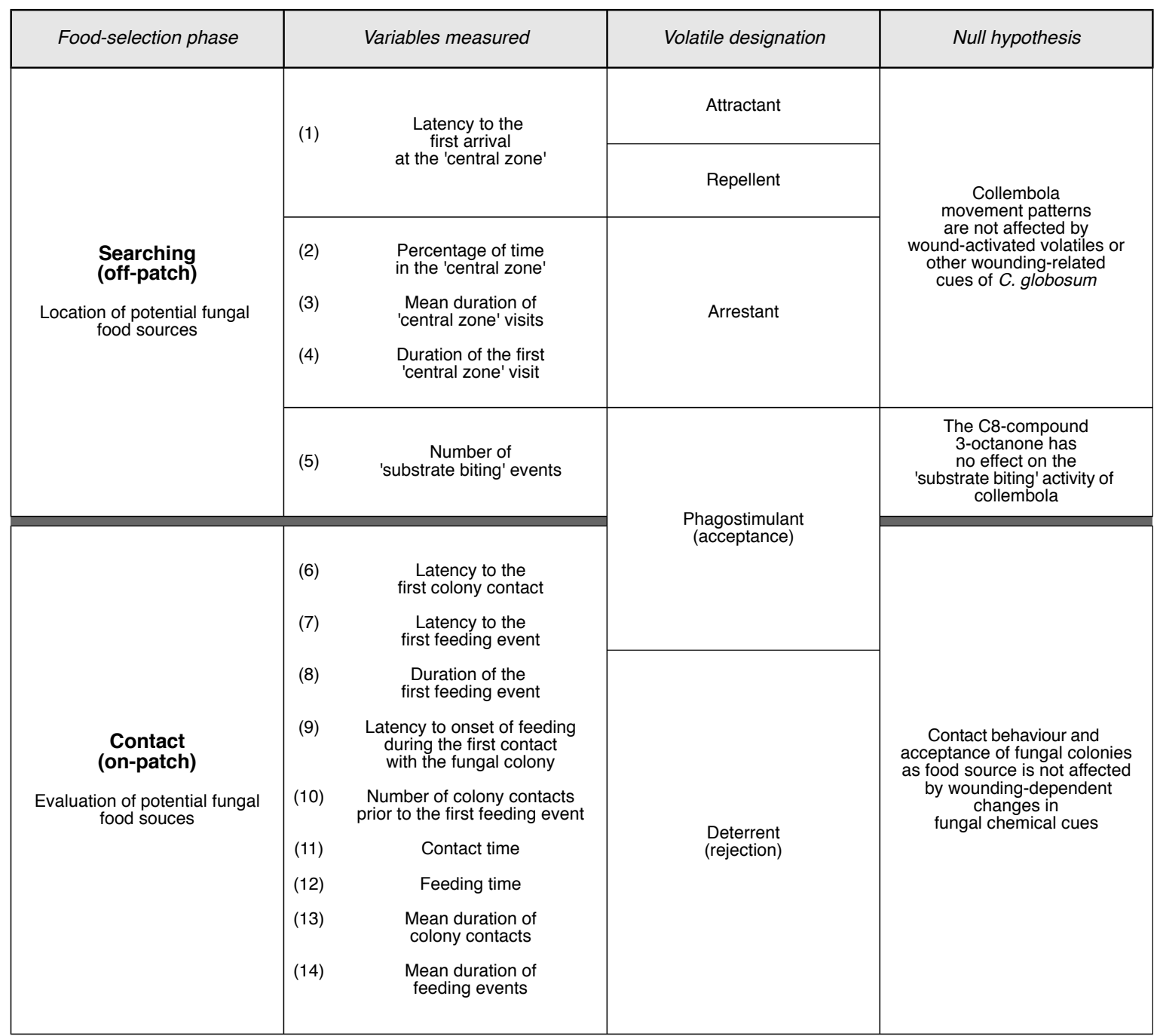

\section{VARIABLES WITH RESPECT TO THE SEARCHING PHASE OF FOOD SELECTION}

The semi-automated tracking platform EthoVision® ${ }^{\circledR}$ T (version 8.0; Noldus Information Technology, Wageningen, Netherlands) (Noldus et al. 2001) was used to analyse movement patterns of Collembola in a no-choice olfactometer in the presence of unwounded and wounded C. globosum colonies without direct contact to the colonies. To reveal differences in the attractivity of respective colonies, in EthoVision ${ }^{\circledR} \mathrm{XT}$ the option 'arena settings' was employed 
to define a 'central zone' around the volatile source and by means of spatial measurements isopod movement was assessed in relation to it. Based on preliminary experimental observation of Collembola responses to a known attractive food source (dried baker's yeast) and yeast-free controls (Appendix: Figure A.2.3) the following variables were selected to reveal volatile-mediated attraction and arrestance: 'latency to the first arrival at the central zone', 'duration of the first central zone visit', 'residence time in the central zone', and 'mean duration of central zone visits' (Table 2.1). If Collembola are more strongly attracted to wounded colonies compared to unwounded colonies they are expected to arrive more rapidly at the 'central zone'. If wound-activated changes in the fungal volatile profile additionally or exclusively cause arrestance, Collembola are expected to reside longer in the 'central zone' of wounded colonies.

\section{VARIABLES WITH RESPECT TO THE CONTACT PHASE OF FOOD SELECTION}

To test whether wounded C. globosum colonies are more accepted as food source than unwounded colonies, the contact behaviour of Collembola was observed. Following information on the behaviour of Collembola was obtained from video recordings using the computer software The Observer ${ }^{\circledR}$ XT (version 10.0, Noldus Information Technology BV, Wageningen, The Netherlands) (Noldus 1991): number of observations with feeding event, contact and feeding time, mean duration of colony contacts and feeding events, latency to the first colony contact and first feeding event, feeding onset latency after the first colony contact, duration of the first feeding event, and number of colony contacts prior to the first feeding event (Table 2.1). Contact to the resource patch was assumed when the Collembola's body or just an antenna overlapped with the patch. Feeding was assumed when Collembola remained stationary whilst the head was moved up and down rhythmically and regularly, and the Collembola's body made short forth and back twitches. If wounded colonies are more accepted than unwounded, Collembola are expected to get in contact and start feeding faster, and spend more time in contact and/or with feeding. Higher acceptance is further assumed if Collembola are arrested at the food source after the first contact, viz. if the duration of the first feeding event is prolonged and the mean duration of colony contacts and/or feeding events is higher. 


\section{'SUBSTRATE BITING' BEHAVIOUR}

Preliminary direct observation of the behaviour of Collembola revealed that F. candida,

S. curviseta, H. nitidus, and Tomocerus vulgaris made feeding characteristic movements in a food-free environment, designated as 'substrate biting', while leaving biting marks on the water agar surface (Figure 2.5). In the presence of a C. globosum colony Collembola left more biting marks the closer they came to the fungus (Figure 2.1a). Furthermore, Collembola primarily moved through and fed on wounded parts of the colony (Figure 2.1b). Based on these observations, I suppose that wound-activated volatiles function as phagostimulants for Collembola and 'substrate biting' may be considered as substrate probing ('test-biting') which is performed by Collembola in the presence of fungal volatiles to locate a fungal food source (Table 2.1). Thus, I hypothesise that wound-activated volatiles of C. globosum induce 'substrate biting' behaviour in Collembola. As wounding of C. globosum fungal tissue caused a significant increase in 3-octanone concentrations (Section 2.4), this C8-compound was tested for triggering 'substrate biting' behaviour (Table 2.1).

(a)

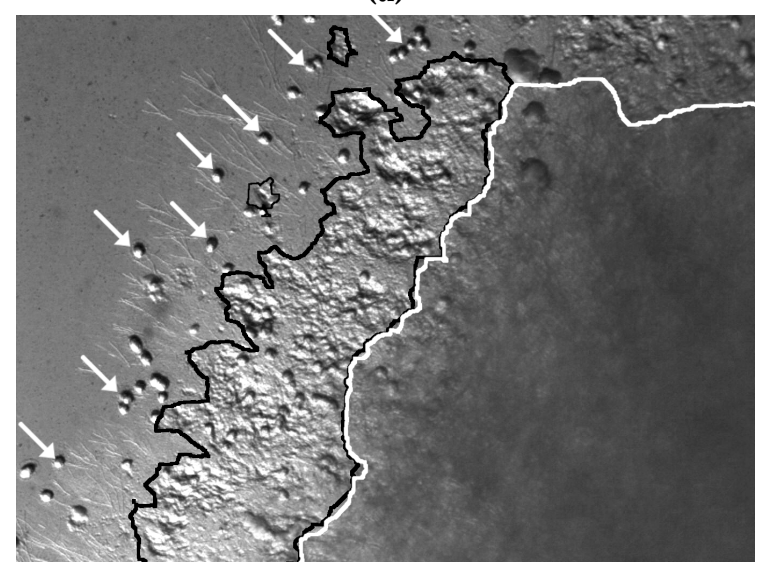

(b)

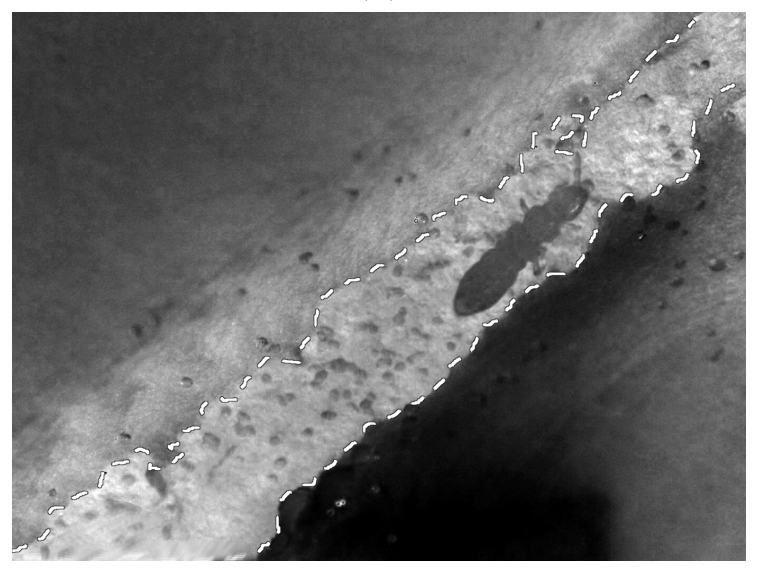

Figure 2.1: Macro photographs of F. candida feeding/biting patterns in the presence of (a) unwounded and (b) wounded C. globosum. (a) The number of biting marks (outlined in black) and fecal pellets (white arrows) increases the closer a Collembola comes to the fungal colony (outlined in white). (b) A Collembola preferably moves along a corridor (indicated by the dashed white line; formed by artificial wounding with a wire loop) through the fungal tissue, leaving feeding traces and fecal pellets. Collembola preferably feed on wounded parts of C. globosum tissue and, even in absence of a fungal colony, Collembola show 'substrate biting' behaviour. These preliminary observations led to the hypothesis that wounding-dependent volatiles trigger 'substrate biting' in Collembola. 


\subsubsection{EXPERIMENTAL SETUP}

\section{TRACKING OF COLLEMbOLA MOVEMENT (OFF-PATCH)}

The movement of individual F. candida, S. curviseta, and H. nitidus was recorded in darkness at $20^{\circ} \mathrm{C}$ in response to unwounded and wounded C. globosum colonies by using a nochoice still air olfactometer and the computer software CyberLink PowerDirector ${ }^{\circledR}($ CyberLink Corporation, Taipei, Taiwan). C. globosum fungal colonies were grown for five days in sterilized circular polypropylene pots $(7 \mathrm{~mm}$ in hight, $25 \mathrm{~mm}$ in diameter) filled with $3 \mathrm{ml}$ MEA. Glass Petri dishes (10.1 cm in diameter), each filled with $45 \mathrm{ml}$ water agar, were used as experimental arenas (Figure 2.2a). The water agar provided a smooth and moist surface, on which Collembola could easily move, and which protected animals from desiccation. According to Auclerc et al. (2010), food-derived volatiles only become relevant when Collembola forage in close distance $(25 \mathrm{~mm})$ to the volatile source. This aspect was considered in the specification of the arena dimensions. The dimensions allowed the animals to move in a maximum distance of $36 \mathrm{~mm}$ and minimum distance of approximately $7 \mathrm{~mm}$ (height of the sample vessel) to the volatile source. The experimental setup consisted of an infrared camera focused on the circular arena, which was illuminated by two infrared lamps (Kema Electronic Co., 12-15 V/DC, M120) installed below. To ensure indirect and even illumination the lamps were placed within a polystyrene box covered with a frosted perspex screen (Figure 2.2b). Immediately before the start of recording a fresh unwounded or wounded fungal colony was placed in the centre of the arena and, thereupon, the arena was covered with a glass plate. A single animal was carefully released into the experimental arena through a glass tube (5 $\mathrm{mm}$ in diameter). Before starting the 15 -minute recording session the animal remained trapped in the glass tube for 2 minutes for acclimatisation. The smooth surface of the polypropylene pots containing the colonies prevented animals from entering or touching the fungal colony. In EthoVision ${ }^{\circledR}$ XT the position of the animal was determined every 0.52 seconds. With 20 replicates per treatment and an equal number observations per treatment and day (randomised order) this experiment was conducted over several days. 
(b)

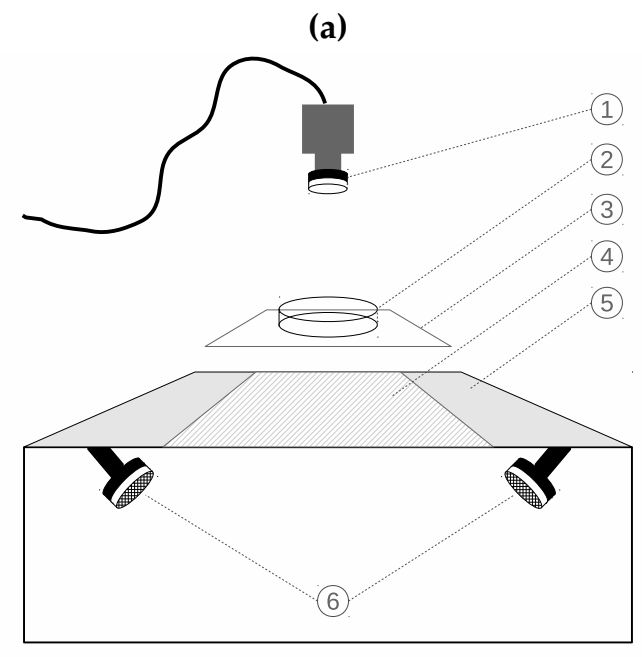

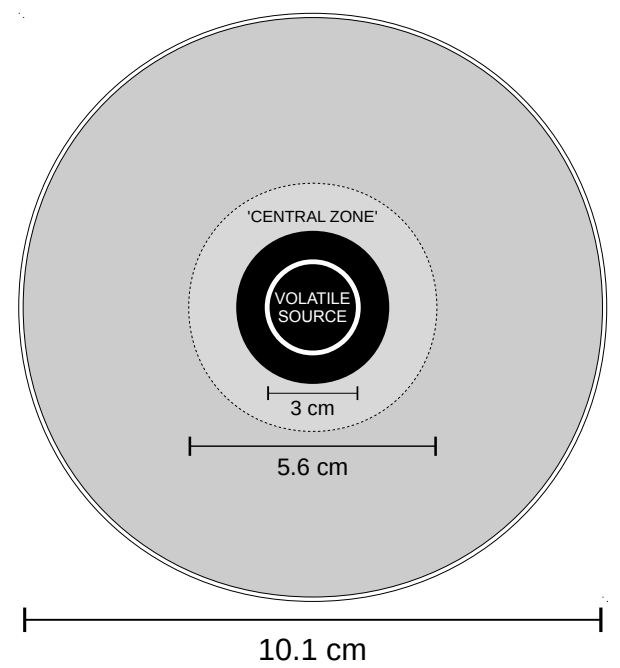

Figure 2.2: Experimental setup for observation of Collembola movement. (a) Dimensions of the experimental arena with the 'central zone' defined around the volatile source. To avoid background noise and disruptions of the automated tracking process, in EthoVision $₫ X T$ the black area enclosing the volatile source was subtracted from the arena.(b) Tracking device; (1) infrared camera, (2) holding device for installation of the experimental arena, (3) arena holder (perspex), (4) frosted perspex screen for even illumination, (5) polystyrene box, (6) infrared lamps (indirect illumination via light reflection).

\section{ObSERVATION OF COLlembola CONTACT BEHAVIOUR (ON-PATCH)}

The on-patch behaviour of F. candida, S. curviseta, and H. nitidus Collembola in the presence of unwounded and wounded colonies of C. globosum was investigated by direct observation via video recordings. This experiment was conducted over several days with an equal number of recordings per treatment and day (randomised order, $\mathrm{n}=20$ ). A Canon EOS 60D reflex camera coupled to a Zeiss Discovery V8 stereo microscope by a macro lens (17-70 mm/F2.84.5) was used for recording. Experimental arenas were prepared as follows: polystyrol Petri dishes (10 $\mathrm{mm}$ in height, $35 \mathrm{~mm}$ in diameter) were filled with $2 \mathrm{ml}$ water agar and provided with a hole ( $4 \mathrm{~mm}$ in diameter) in the centre. The holes were filled with $20 \mu \mathrm{l}$ malt extract agar and, after hardening, fungal tissue was transferred to the medium. Fungal colonies were directly incubated in experimental arenas for four days. The wounding treatment was done immediately before starting a recording and subsequently, a single animal was released at the margin of the arena. 


\section{QUANTIFICATION OF COLlembola 'SUbSTRATE biting' behaViour}

F. candida and S. curviseta Collembola were exposed to the authentic compound 3-octanone in concentrations of $\mathrm{w} / \mathrm{w} 10^{-2}-10^{-4}$ (diluted with pentane) and pure pentane served as solvent control. Standard 24-well plates ( $15.5 \mathrm{~mm}$ well diameter) were filled with sterilized water agar ( $0.5 \mathrm{ml} /$ well) and, after hardening, $10 \mu \mathrm{l}$ of compound solution were pipetted on the agar surface of each well. After evaporation of the solvent a single animal was added to each well. The plates were covered with fine gauze and a lid to prevent animals from escaping. After 30 minutes, the animals were carefully removed and the number of wells with bite marks was counted by means of a stereo microscope. Wells with bite marks on the agar surface were rated with value ' 1 ' and wells without marks with ' 0 ' to obtain a binary data structure.

\subsubsection{STATISTICS}

All statistical analysis were conducted using the R statistical environment (RStudio, version 1.0.153 for Mac OS X, R Development Core Team (2008)). Statistical tests regarding behavioural responses were individually applied on the three different Collembola species F. candida, S. curviseta, and H. nitidus, i.e. differences in behavioural responses between species were not tested to avoid bias caused by differences in species-specific physical properties.

Linearity of calibration curves used for determination of headspace concentrations of individual volatile compounds was tested by means of a linear model. Headspace concentrations $\left(\mathrm{ng} / \mathrm{cm}^{3}\right)$ of 3-octanone, 3-octyl acetate, and 3-methyl-1-butanol were calculated from model estimates (slope, intercept) of calibration plots (Appendix: Figure A.2.1). Treatments (C. globosum unwounded, wounded) were compared using the non-parametric WilcoxonMann-Whitney test with exact null distribution $(\alpha=0.05$, distribution='exact', function 'wilcox_test', package 'coin' in R), individually applied on each volatile compound, since original as well as log-transformed data did not match the normal distribution pattern.

The Wilcoxon-Mann-Whitney test was also applied to test whether the 'residence time in the central zone' and the 'mean duration of central zone visits' differ between treatments (unwounded, wounded) (searching phase). With respect to the contact phase, the effect of wounding on the 'contact time' with fungal colonies, 'feeding time', 'mean duration of 
colony contacts', 'mean duration of feeding events', and the 'colony contact frequency prior to the first feeding event' in the presence of unwounded and wounded fungal colonies, was also analysed using Wilcoxon-Mann-Whitney tests. Observations without a 'central zone' visit, contact and/or feeding event were excluded from the calculation of the 'mean duration of central zone visits', the 'mean duration of colony contacts', and the 'mean duration of feeding events', respectively. Effect size is given by Cohen's d (difference between two means divided by a standard deviation) (Cohen 1988) in case of same sample size, and Hedge's g in case of different sample size.

Time-dependent event data obtained from the searching phase ('latency to the first arrival at the central zone', 'duration of the first central zone visit') and the contact phase ('latency to the first contact', 'latency to the first feeding event', 'duration of the first colony contact', 'duration of the first feeding event', 'feeding onset latency after the first colony contact') in response to unwounded and wounded C. globosum colonies, were analysed using Cox regression models (function 'coxph', package 'survival' in R) based on likelihood estimates. With respect to the 'duration of the first central zone visit', the 'duration of the first colony contact', the 'duration of the first feeding event', and the 'feeding onset latency after the first colony contact', durations that exceeded the observation time were censored and rated as ' 0 ' in the 'status' argument of a Cox model. Prior to the application of a Cox regression model the global as well as per-variable proportionality of hazards was tested by goodness-of-fit $\tilde{\chi}^{2}$ tests (function 'cox.zph' in R) and visually examined by means of partial residuals plots as proposed by Schoenfeld $(1980 ; 1982)$. The effect size is represented by the hazard ratio $(\exp ($ coef $))$. As the hazard rate is defined as the instantaneous risk for the occurrence of an event within a defined observation period for a particular group, the hazard ratio represents the difference between hazard rates of treatment groups.

The effect of treatment (unwounded, wounded) on the total number of feeding events (binary data) was tested using a generalized linear model with binomial error distribution and 'logit' link function (function 'glm' in R). A generalized linear model with binomial distribution and 'logit' link function was also applied on the binary data set obtained in the course of the 'substrate biting' assay to test whether the number of 'substrate biting' events of F. candida and S. curviseta differ between 3-octanone concentrations $\mathrm{w} / \mathrm{w} 10^{-4}$ and $10^{-3}$, and pentane solvent controls. The explanatory variable '3-octanone concentration' entered the model as a continuous variable (ranging from 0 to $10^{-3}$ ). Integration of the second order term of '3-octanone concentration' didn't improve the model and was excluded. 


\subsection{Results}

\subsubsection{VOLATILE PROFILES OF UNWOUNDED AND WOUNDED C. globosum COLONIES}

The headspace SPME-GC-MS analysis of volatile profiles of C. globosum grown on MEA resulted in the detection of 18 compounds. Whereas 11 compounds were detected in C. globosum as well as MEA control samples, 4 compounds were exclusively present in MEA control samples, and three compounds could be found to be produced by C. globosum (Appendix: compound list Table A.2.2; chromatograms Figure A.2.2). Fungal volatiles were identified as 3-octanone, 3-octyl acetate, and 3-methyl-1-butanol. Compound concentrations were significantly increased in response to the wounding treatment concerning 3-octanone (WilcoxonMann-Whitney test, $z=-3.36, p<0.001$, Cohen's d=12.42, CI: 7.59, 17.25) and 3-octyl acetate (Wilcoxon-Mann-Whitney test, $\mathrm{z}=-2.21, p=0.028$, Cohen's d=1.68, CI: 0.43, 2.93) Figure 2.3a. 2.3b). Concentrations of 3-methyl-1-butanol were not affected by wounding (WilcoxonMann-Whitney test, $\mathrm{z}=0.53, p=0.645$, Cohen's d=0.47, CI:-0.62, 1.55) (Figure 2.3c).

(a)

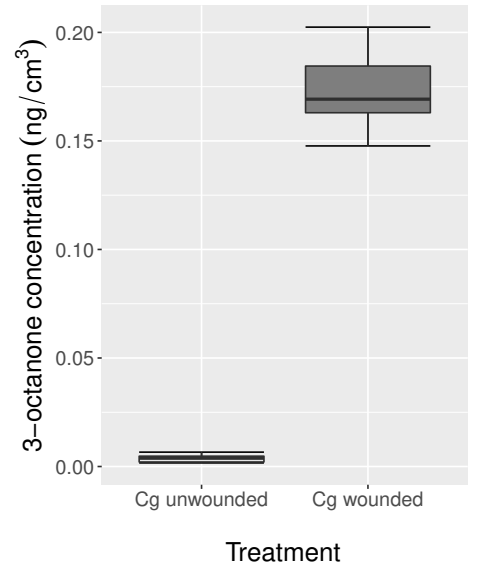

(b)

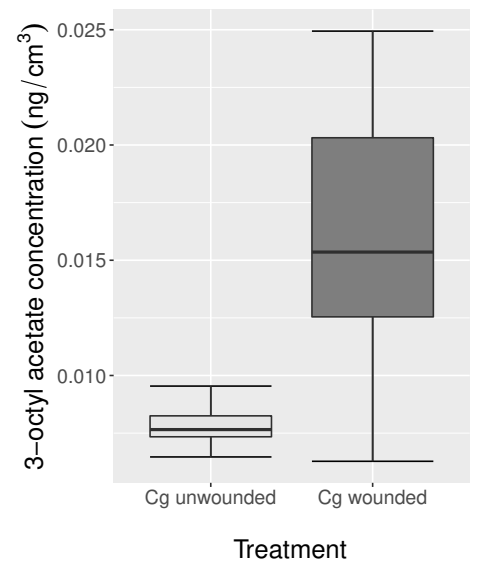

(c)

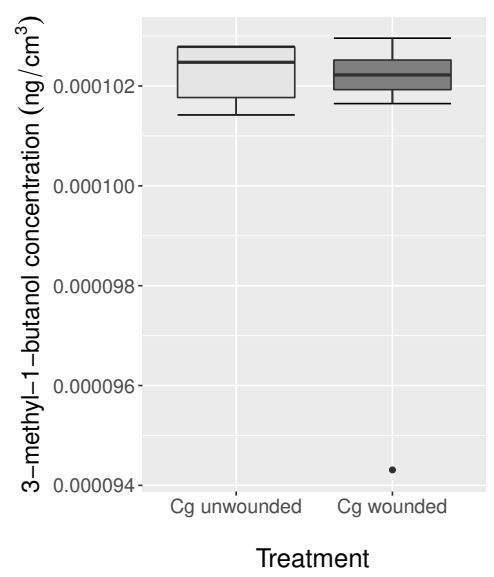

Figure 2.3: Headspace concentrations $\left(\mathrm{ng} / \mathrm{cm}^{3}\right)$ of volatile compounds (a) 3-octanone, (b) 3-octyl acetate, and (c) 3-methyl-1-butanol identified from unwounded ( $\mathrm{gg}$ unwounded, $\mathrm{n}=8$ ) and wounded (Cg wounded, $\mathrm{n}=8$ ) C. globosum colonies. 


\subsubsection{SEARCHING PHASE OF FOOD SELECTION}

The tendency of F. candida, S. curviseta, and H. nitidus to arrive at the 'central zone' and the 'duration of the first central zone visit' as well as the 'residence time in the central zone' were not affected by the tissue wounding treatment (Table 2.2; Appendix: Figure A.2.4. A.2.5, A.2.6, A.2.7). These results allow the acceptance of the null hypothesis and indicate that there were no differences in volatile-mediated attraction or arrestance of Collembola between the volatile sources (unwounded and wounded C. globosum colonies).

Table 2.2: Searching phase: test statistic for variables 'latency to the first arrival at the central zone' (arrival tendency), 'duration of the first central zone visit' (departure tendency) (Cox regression), 'residence time in the central zone', and 'mean duration of central zone visits' (Exact Wilcoxon-Mann-Whitney test). For Cox regression models the $\tilde{\chi}^{2}$ value and for Wilcoxon tests the $Z$-score is given.

\begin{tabular}{ll|lcccc|c}
\hline Species & Variable & $N$ & Events & $D f$ & $\tilde{\chi}^{2} / Z$ & $\exp (\text { coef })^{(*)}$ & $P-$ value \\
\hline F. candida & First arrival & 40 & 29 & 1 & 0.13 & 1.14 & 0.723 \\
H. nitidus & First arrival & 40 & 39 & 1 & 0.03 & 1.06 & 0.859 \\
S. curviseta & First arrival & 40 & 36 & 1 & 0.03 & 1.06 & 0.854 \\
\hline F. candida & Duration first visit & 29 & 27 & 1 & 0.24 & 0.83 & 0.624 \\
H. nitidus & Duration first visit & 39 & 37 & 1 & 0.93 & 0.71 & 0.335 \\
S. curviseta & Duration first visit & 36 & 33 & 1 & 0.07 & 1.10 & 0.790 \\
\hline F. candida & Time in zone & 40 & & 1 & 1.10 & & 0.276 \\
H. nitidus & Time in zone & 40 & & 1 & -0.81 & & 0.925 \\
S. curviseta & Time in zone & 40 & & 1 & 0.69 & & 0.499 \\
\hline F. candida & Mean duration & 29 & & 1 & 0.71 & & 0.747 \\
H. nitidus & Mean duration & 39 & & 1 & 0.17 & & 0.879 \\
S. curviseta & Mean duration & 36 & & 1 & -0.36 & & 0.731 \\
\hline
\end{tabular}

(*) Ratio of hazard rates between treatment groups (unwounded vs. wounded C. globosum colonies). Given hazard ratios relate to the wounded treatment group

\subsubsection{CONTACT PHASE OF FOOD SELECTION}

In general, the contact behaviour of the three tested Collembola species was influenced by fungal tissue wounding, however, the effect was not consistent across all tested variables (Table 2.3, 2.4). Whereas the number of observations with feeding event was not affected by fungal treatment in F. candida (deviance $=2.18, \mathrm{df}=1, p=0.140$ ) and $S$. curviseta (deviance $=0$, $\mathrm{df}=1, p=0.100$ ), significantly more $H$. nitidus individuals exhibited feeding on wounded colonies compared to unwounded colonies (deviance $=5.13, \mathrm{df}=1, p=0.023$ ) (Appendix: Figure A.2.8b). H. nitidus tendency to start feeding on wounded colonies was 3.41 times higher 
compared to unwounded colonies (Table 2.4 Appendix: Figure A.2.15b). Moreover, H. nitidus individuals spent a significantly higher proportion of the observation time at wounded colonies and fed significantly longer on these colonies compared to unwounded colonies (Table 2.3. Appendix: Figure A.2.10b, A.2.12b). The duration of both colony visits and feeding events at wounded colonies was significantly longer compared to unwounded colonies (Appendix: Figure A.2.11b, A.2.13b). Similar to H. nitidus, the tendency of F. candida individuals to start feeding on a wounded C. globosum colony was 2.08 times higher compared to unwounded colonies (Table 2.4. Appendix: Figure A.2.15a). The duration of colony visits was also significantly longer in the wounding treatment group (Table 2.3, Appendix: Figure A.2.11a). Once F. candida contacted a colony, onset of feeding was 2.47 times faster in the presence of a wounded colony compared to unwounded colonies (Table 2.4. Appendix: Figure A.2.16a ). With respect to $S$. curviseta, exclusively the colony 'contact frequency prior to the first feeding event' was significantly affected by the treatment (Table 2.3). Individuals less frequently visited wounded colonies prior to feeding compared to unwounded colonies (Appendix: Figure A.2.9c). Contrary to expectations, with inverted hazard ratios $(1 / \exp ($ coef $))$ of 2.44 and 2.22 the tendency of S. curviseta and F. candida Collembola to contact an unwounded C. globosum colony was more than twice as high as the tendency to contact a wounded colony (Table 2.4 Appendix: Figure A.2.14a, A.2.14c). Further contrasting results, viz. wounding-related negative effects on Collembola acceptance, were not found. 
Table 2.3: Contact phase: Wilcoxon-Mann-Whitney test statistic of variables: 'colony contact frequency prior to the first feeding event', 'contact time', 'mean duration of colony contacts', 'feeding time', 'mean duration of feeding events'. Effect size is represented by Cohen's $d$ in case of equal sample size and by Hedge's $g$ in case of different sample size, with confidence interval in parentheses.

\begin{tabular}{|c|c|c|c|c|c|c|c|}
\hline Species & Variable & $N$ & $D f$ & $Z$ & Effect size & $P$-value & $(*)$ \\
\hline F. candida & Contacts prior feeding & 30 & 1 & 1.83 & $0.49(-0.28,1.26)$ & 0.070 & \\
\hline H. nitidus & Contacts prior feeding & 17 & 1 & 0.67 & $0.39(-0.76,1.52)$ & 0.532 & \\
\hline S. curviseta & Contacts prior feeding & 26 & 1 & 2.85 & $1.05(0.19,1.91)$ & 0.004 & $\nabla$ \\
\hline F. candida & Contact time & 40 & 1 & -1.65 & $-0.40(-1.05,0.24)$ & 0.102 & \\
\hline H. nitidus & Contact time & 40 & 1 & -2.06 & $-0.77(-1.43,-0.11)$ & 0.040 & $\Delta$ \\
\hline S. curviseta & Contact time & 40 & 1 & 1.10 & $0.49(-0.16,1.14)$ & 0.280 & \\
\hline F. candida & Mean contact & 40 & 1 & -2.03 & $-0.29(-0.93,0.35)$ & 0.043 & $\Delta$ \\
\hline H. nitidus & Mean contact & 35 & 1 & -2.34 & $-0.72(-1.43,-0.01)$ & 0.019 & $\Delta$ \\
\hline S. curviseta & Mean contact & 38 & 1 & -0.64 & $-0.47(-1.14,0.20)$ & 0.534 & \\
\hline F. candida & Feeding time & 40 & 1 & -1.92 & $-0.55(-1.21,0.10)$ & 0.055 & \\
\hline H. nitidus & Feeding time & 40 & 1 & -2.46 & $-0.76(-1.42,-0.09)$ & 0.013 & $\Delta$ \\
\hline S. curviseta & Feeding time & 40 & 1 & 0.48 & $0.34(-0.31,0.98)$ & 0.637 & \\
\hline F. candida & Mean feeding & 30 & 1 & -0.73 & $-0.24(-1.00,0.52)$ & 0.483 & \\
\hline H. nitidus & Mean feeding & 17 & 1 & -2.21 & $-0.68(-1.84,0.48)$ & 0.027 & $\Delta$ \\
\hline S. curviseta & Mean feeding & 26 & 1 & 0.74 & $0.40(-0,42,1.22)$ & 0.479 & \\
\hline
\end{tabular}

Table 2.4: Contact phase: Cox regression test statistic for time dependent event data. Variables: 'latency to the first colony contact', 'latency to the first feeding event', 'duration of the first feeding event', and 'feeding onset latency after the first contact'.

\begin{tabular}{ll|lllll|lc}
\hline Species & Variable & $N$ & Events & $D f$ & $\tilde{\chi}^{2}$ & exp $(\text { coef })^{(*)}$ & $P-$ value & $(* *)$ \\
\hline F. candida & First colony entering & 40 & 40 & 1 & 5.32 & 0.45 & $\mathbf{0 . 0 2 2}$ & $\nabla$ \\
H. nitidus & First colony entering & 40 & 35 & 1 & 0.04 & 1.07 & 0.849 & $\nabla$ \\
S. curviseta & First colony entering & 40 & 38 & 1 & 6.03 & 0.41 & $\mathbf{0 . 0 1 4}$ & $\nabla$ \\
\hline F. candida & First feeding & 40 & 30 & 1 & 3.93 & 2.08 & $\mathbf{0 . 0 4 7}$ & $\boldsymbol{\Delta}$ \\
H. nitidus & First feeding & 40 & 17 & 1 & 5.91 & 3.41 & $\mathbf{0 . 0 2 2}$ & $\boldsymbol{\Delta}$ \\
S. curviseta & First feeding & 40 & 26 & 1 & 0.16 & 0.86 & 0.692 & \\
\hline F. candida & Duration first feeding & 30 & 28 & 1 & 0.74 & 0.72 & 0.391 \\
H. nitidus & Duration first feeding & 17 & 16 & 1 & 2.46 & 0.37 & 0.117 \\
S. curviseta & Duration first feeding & 26 & 26 & 1 & 0.53 & 1.36 & 0.465 \\
\hline F. candida & Feeding onset latency & 30 & 30 & 1 & 5.35 & 2.47 & $\mathbf{0 . 0 2 1}$ & $\mathbf{\Delta}$ \\
H. nitidus & Feeding onset latency & 17 & 17 & 1 & 1.25 & 1.86 & 0.263 \\
S. curviseta & Feeding onset latency & 26 & 26 & 1 & 0.57 & 1.36 & 0.452 \\
\hline
\end{tabular}

$(*)$ Ratio of hazard rates between treatment groups (unwounded vs. wounded C. globosum colonies). Given hazard ratios relate to the wounded treatment group, i.e. values lower than 1 indicate decreased hazard and values higher than 1 indicate increased hazard in the wounded treatment group compared to the unwounded treatment group.

$(* *)$ With regard to the respective variable, $\nabla$ indicates a significantly decreased hazard and $\boldsymbol{\Delta}$ a significantly increased hazard in the wounded treatment group in comparison to the unwounded treatment group. 


\subsection{4 'SUBSTRATE BITING' BEHAVIOUR OF F. candida AND S. curviseta}

The 'substrate biting' behaviour of Collembola (total number of 'substrate biting' events) was significantly influenced by the presence of 3-octanone (Binomial regression, F. candida: intercept $=-0.71$, slope $=829.94, \mathrm{z}=3.47, p<0.001 ;$ S. curviseta: intercept=-0.54, slope $=477.11$, $\mathrm{z}=1.98, p=0.047)$ with an increase in biting events with increasing 3-octanone concentration (Figure 2.4). In the course of this experiment it turned out that Collembola were paralysed by 3-octanone at a concentration of $\mathrm{w} / \mathrm{w} 10^{-2}$, consequently, this concentration was excluded from the statistical analysis.

(a)

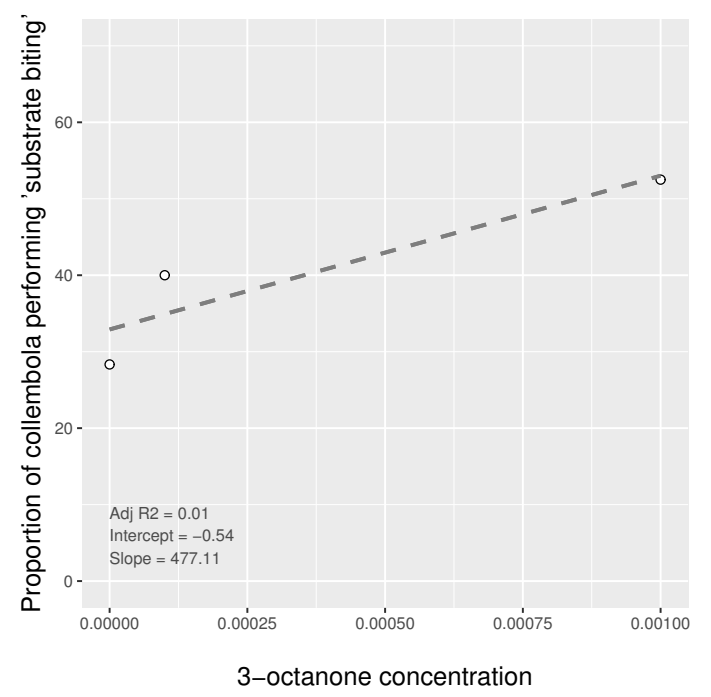

(b)

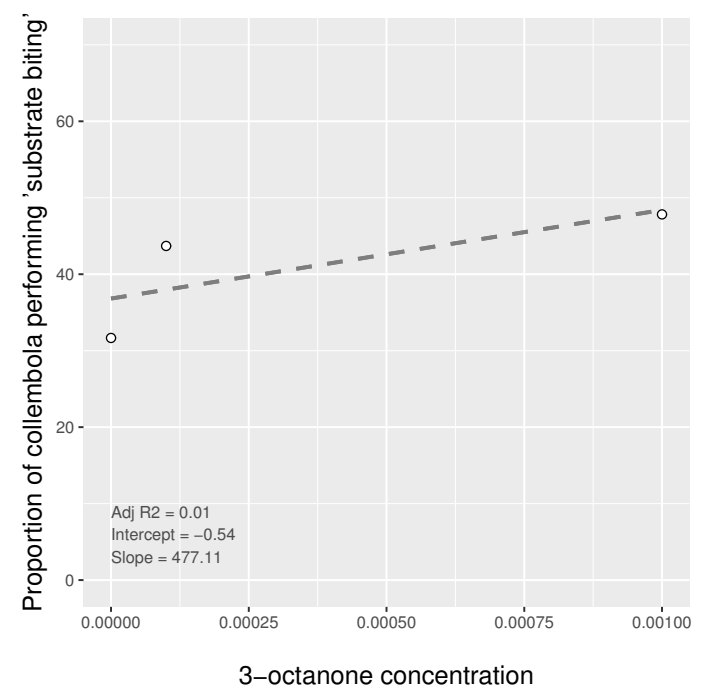

Figure 2.4: Number of 'substrate biting' events of (a) F. candida and b. S. curviseta in response to 3-octanone concentrations $\left(\mathrm{w} / \mathrm{w} 10^{-4}, 10^{-3}\right)$ and paraffin controls. F. candida: $p<0.001\left(10^{-4}: \mathrm{n}=120,10^{-3}: \mathrm{n}=120\right.$, control: $n=120) ;$ S. curviseta: $p=0.047\left(10^{-4}: n=119,10^{-3}: n=115\right.$, control: $\left.n=120\right)$. 
(a)

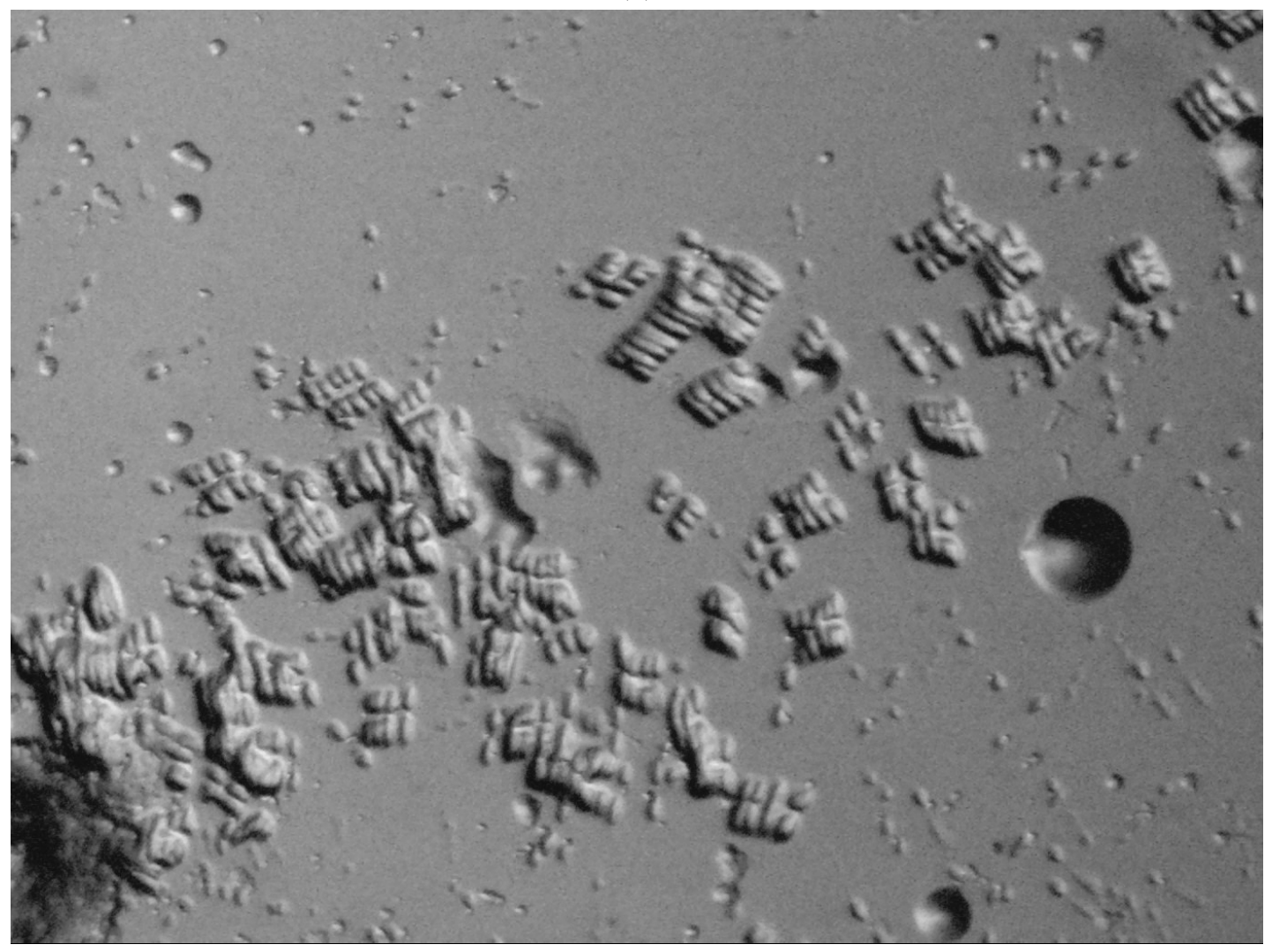

(b)
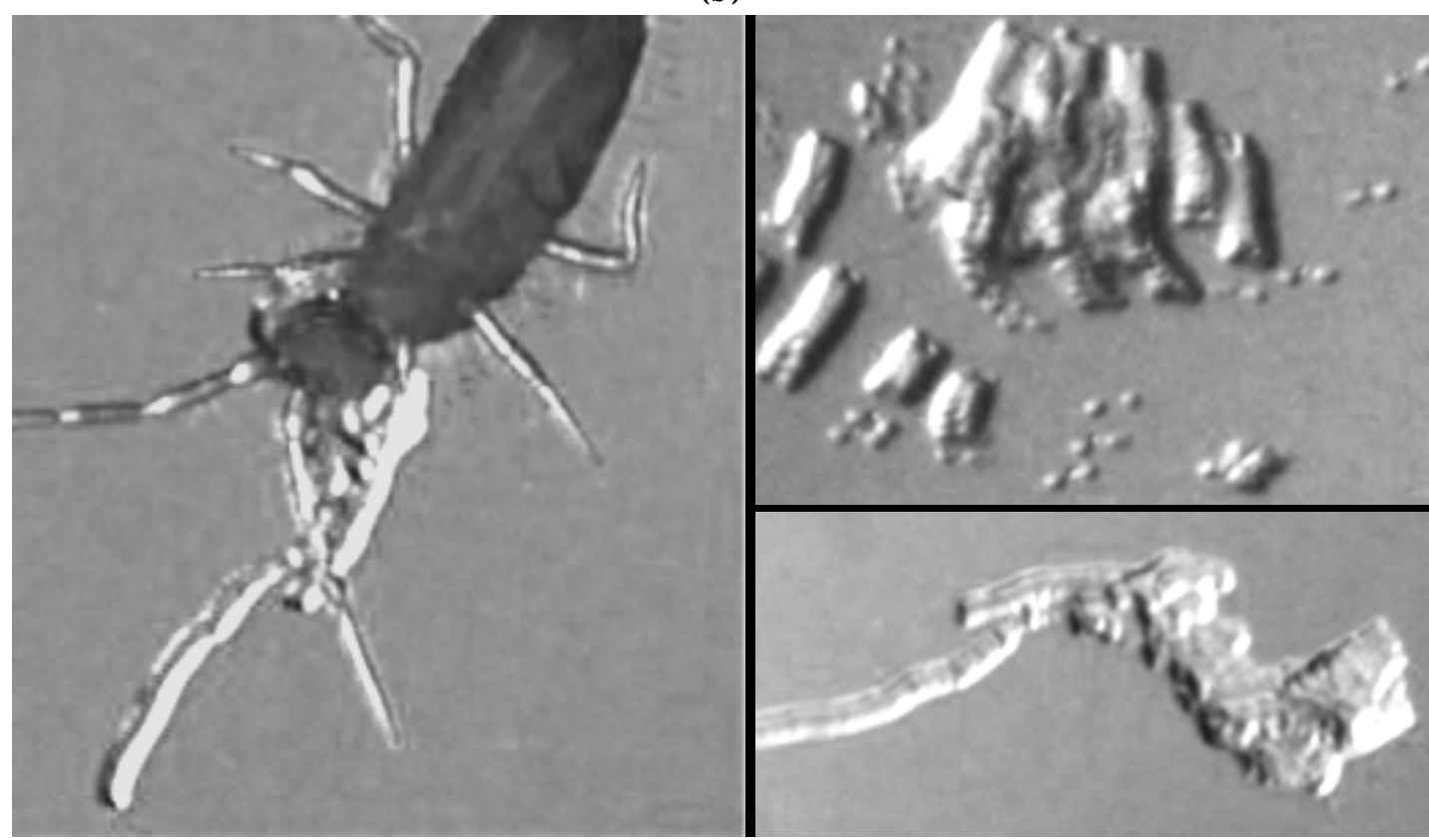

Figure 2.5: Macro photographs of biting marks of (a) F. candida and (b) S. curviseta in the presence of 3octanone. 


\subsection{Discussion}

The present study, for the first time, investigated the effect of fungal tissue wounding and related changes in fungal chemistry on the foraging behaviour of facultative fungivorous Collembola by focussing on the searching phase (food location) and the contact phase (food acceptance) of foraging to get a holistic view on the food selection process (Schoonhoven et al. 2005). Overall, the present study confirms that fungal chemical properties, at least to some extent, influence the outcome of Collembola-fungus interactions, as it has already been proposed by earlier studies (Böllmann et al.|2010, Rohlfs et al. 2007, Stötefeld et al. 2012).

The headspace analysis of volatiles resulted in the identification of three compounds, 3octanone, 3-octyl acetate, and 3-methyl-1-butanol, with increased concentrations of the two volatile oxylipins, 3-octanone and 3-octyl acetate, in wounded colonies. Whereas 3-octanone and 3-methyl-1-butanol have frequently been reported as common mushroom volatiles (e.g. Börjesson et al. 1992, Fiedler et al. 2001, Korpi et al. 2009), 3-octyl acetate was primarily identified from essential oils of several plant species (e.g. Akin et al. 2010, Handa et al. 1964), but also from Penicillium species (Matysik et al.|2008, Nilsson et al.|1996); however, its precursors, the oxylipin 3-octanol and acetic acid, are well known to be produced by different fungal species (Abraham and Berger 1994, Fiedler et al.|2001, Mburu et al.|2011, Thakeow et al.|2008). As 3-octyl acetate was consistently present across all samples, measured on different days, with significantly increased concentrations in wounded colonies, it can be excluded that this compound originated from a contamination. The wound-activated increase in eight-carbon oxylipin volatile compounds caused by artificial mechanical wounding of fungal tissue accords with results of other studies; similar increases were reported for Marchantia polymorpha (Kihara et al.2014) and Agaricus bisporus (Combet et al.2009).

Contrary to my expectation, movement patterns of the three Collembola species F. candida, S. curviseta, and $H$. nitidus were not affected by wound-activated changes in the volatile profile of C. globosum. This indicates that neither the blind and hemiedaphic species F. candida nor the hemi- and epedaphic species S. curviseta, and H. nitidus use wound-activated volatiles as information to find fungal food from distance. However, as fungi strongly differ in their wounding-specific volatile profiles, especially with respect to the activation and increase of oxylipin volatiles (Chapter 4 , Table 4.3, the generality of this statement needs to be tested by including further species of filamentous fungi. Up to now, this is the first study that directly links wound-activated changes in fungi and spatial foraging behaviour of Collembola, but, other observations of arthropod responses to 3-octanone were done with 
respect to different beetle species, lepidoptera, and the earthworm E. fetida. Whereas some beetle species were attracted to 3-octanone (Holighaus et al. 2014, Pierce et al. 1991a), the behaviour of other beetles, lepidoptera, and earthworms, was not affected by this compound (Fäldt et al. 1999, Pierce et al. 1991a, Tabata et al. 2011, Zirbes et al. 2011). Simultaneously, these studies demonstrate that behavioural responses can be different in respect of different oxylipin compounds.

In contrast to the unexpected results with respect to the searching phase of food selection, Collembola responses observed during the contact phase and the 'substrate biting' assay indicate that wound-activated changes in fungal chemistry become relevant when looking at behaviours associated with colony contact and feeding. Whereas during the searching phase only volatiles could be used as information, it is very likely that gustatory, tactile, and visual properties were used as cues for evaluation during the contact phase. The results strongly suggest that the volatile oxylipin 3-octanone functions as volatile food-finding cue and phagostimulant for Collembola and provide first evidence that at least some fungal volatile oxylipins function as cues in an analogous manner to plant volatile oxylipins (e.g. Halitschke et al. 2004, Mitchell and McCashin 1994, Murray et al. 1972, Zhang 2016). Since an increased 3-octanone concentration stimulated a higher number of Collembola to show 'substrate biting' behaviour, the higher concentration of this compound in wounded C. globosum colonies was also most likely responsible for the higher acceptance of these colonies as food source, primarily indicated by higher feeding tendencies. A possible scenario is that 'substrate biting' is an integral part of the foraging process and regularly exhibited by Collembola during the searching phase to permanently test if fungal food is present in immediate surroundings. If relevant fungal volatiles are present, 'substrate biting' behaviour will increase, turn to feeding, and finally lead to an increase in volatile oxylipin emissions. Presumably, the absence of volatile and/or non-volatile deterrents and presence of phagostimulants will induce continuous feeding, as it is supposed to be the mode of action in plant-herbivore systems (Schoonhoven 1968). According to Schoonhoven et al. (2005) the here observed 'substrate biting' behaviour can be considered as 'test-biting' (probing) and interpreted as a kind of exploratory behaviour, which is common and frequently observed in herbivorous arthropods (e.g. Chapman and Bernays 1989, Schoonhoven et al. 2005). As this behaviour was observed in different Collembola species it is suggested to be a fixed component of Collembola foraging behaviour. However, since only one compound was tested here, it needs to be tested whether oxylipin volatiles generally stimulate 'test-biting' and feeding in Collembola. 
When focussing on the contact phase, it appears that the Collembola species F. candida, S. curviseta, and $H$. nitidus, perceive and use fungal cues for the evaluation of potential food sources differently. Whereas higher acceptance of wounded C. globosum colonies by F. candida and H. nitidus was reflected in different behavioural variables and most clearly shown for $H$. nitidus, only the lower number of contacts prior to the first feeding event indicated higher acceptance of these colonies by S. curviseta. The tendency of F. candida and S. curviseta to get in first contact with wounded colonies was even lower. This unexpected result contrasts with subsequent behavioural responses, viz. higher feeding activity and colony contact. Since Collembola were raised on a baker's yeast-based diet, a possible explanation is that wound-activated oxylipin volatiles of $C$. globosum represent unknown stimuli that initially elicited avoidance of wounded colonies by F. candida and S. curviseta.

Behavioural differences between Collembola species indicate the presence of different foodfinding mechanisms and may explain observed species-specific selective feeding on (Moore et al. 1987, Varga et al. 2002) and preferences for certain fungal food sources (Hiol Hiol et al. 1994, Sadaka-Laulan et al.|1998, Thimm and Larink|1995, Tordoff et al. 2008, Visser and Whittaker 1977). In the field of soil biology, a long-standing question is how the great diversity of soil faunal communities could emerge, obviously, without clear niche differentiation, termed 'the enigma of soil animal diversity' (Anderson 1975). One hypothesis is that the high diversity of decomposer communities results from different exploitation of fungal resources. In fact, different soil animal species show distinct feeding preferences, and with particular respect to mites and Collembola, it was demonstrated that certain fungal species were preferred as food source (Maraun et al. 2003). However, selective feeding on fungi is assumed to be more strongly exhibited by epedaphically living species than by hemiedaphic species (Walsh and Bolger 1990). The finding that the epedaphic species H. nitidus showed the clearest response to wound-activated changes in fungal chemistry among the tested species supports this assumption. Species-specific responses to fungal volatiles may result in differential resource use, which might reduce interspecific competition and facilitate species coexistence.

Some limitations need to be specified with respect to the results of the present study. Existing studies on both plant-insect and fungus-arthropod interactions have demonstrated that behavioural responses to volatile emissions are highly variable and can be affected by synergistic (e.g. Brand et al. 1977, Dowd and Bartelt 1991, Mburu et al. 2013, Nout and Bartelt 1998) as well as concentration-dependent effects (e.g. Pierce et al.1991a, Thakeow et al.2008), and the type of interaction (host, non-host) (Hulcr et al. 2011). Different oxylipin volatiles 
can provoke contrasting behavioural responses in the same species as it was shown for the fungivorous beetle $B$. reticulatus in the presence of the three oxylipin volatiles 1-octen-3-ol, 3octanone, and 3-octanol (Holighaus et al. 2014). Conversely, the same compound can induce contrasting responses in different species, as it was extensively investigated with respect to the plant characteristic oxylipin volatile (Z)-3-hexenol (Wei and Kang 2011), but also found in fungus-arthropod interactions with respect to the common mushroom oxylipin volatile 1octen-3-ol. This compound elicited attraction in the erotylid beetle T. bipustulata, the ciid beetle S. affinis (Drilling and Dettner 2009), and the coccinellid beetle P. vigintimaculata (Tabata et al. 2011), repelled the tenebrionid beetle B. reticulatus (Holighaus et al. 2014) and P. minuta Collembola (Sawahata et al. 2008), and functions as antifeedant for banana slugs (Wood et al. 2001). In the light of this variability, the foraging behaviour of fungivorous arthropods needs detailed investigation by testing the effect of further fungal (oxylipin) volatiles to assess the importance of volatiles for the emergence of different types of mutualistic and antagonistic fungus-arthropod interactions.

In conclusion, the present study represents a new approach for investigating Collembola foraging behaviour in detail by focussing on the two phases of food selection, the searching and the contact phase. Direct observation of individual Collembola responses offered novel insights on the importance of fungal volatiles in mediating fungus-arthropod interactions and Collembola food selection. Three Collembola species were found to respond differently to volatiles on different levels of the foraging process indicating the presence of speciesspecific foraging strategies. Moreover, this study revealed a hitherto completely overlooked behavioural component of Collembola foraging, a probing behaviour designated as 'testbiting' (Schoonhoven et al. 2005). With particular focus on the effect of wound-activated volatile oxylipin emissions, the common fungal oxylipin volatile 3-octanone is suggested to act as food-finding cue and phagostimulant for Collembola. Further behaviour-modifying (oxylipin) volatiles and non-volatile chemical aspects of Collembola-fungus interactions remain to be identified to fully understand the complexity of Collembola foraging decisions. 


\section{REFERENCES}

Abraham BG and Berger RG, 1994. Higher fungi for generating aroma components through novel biotechnologies. Journal of Agricultural and Food Chemistry, 42(10):2344-2348. ISSN 15205118. doi:10.1021/jf00046a050.

Akin M, Demirci B, Bagci Y, and Baser K, 2010. Antibacterial activity and composition of the essential oils of two endemic Salvia sp. from Turkey. African Journal of Biotechnology, 9(15):2322-2327. ISSN 1684-5315. doi:10.4314/ajb.v9i15.

Ameye M, Allmann S, Verwaeren J, Smagghe G, Haesaert G, Schuurink RC, and Audenaert K, 2017. Green leaf volatile production by plants: a meta-analysis. New Phytologist. ISSN 14698137. doi:10.1111/nph.14671.

Anderson J, 1975. The enigma of soil animal species diversity. In J Vanek, editor, Progress in soil zoology, pages 51-58. Springer, Dordrecht. doi:10.1007/978-94-010-1933-0_5.

Auclerc A, Libourel PA, Salmon S, Bels V, and Ponge JF, 2010. Assessment of movement patterns in Folsomia candida (Hexapoda: Collembola) in the presence of food. Soil Biology and Biochemistry, 42(4):657-659. ISSN 00380717. doi:10.1016/j.soilbio.2009.12.012.

Bardgett RD, Whittaker JB, and Frankland JC, 1993. The diet and food preferences of Onychiurus procampatus (Collembola) from upland grassland soils. Biology and Fertility of Soils, 16:296-298. doi:10.1007/BF00369308.

Bengtsson G, Hedlund K, and Rundgren S, 1991. Selective odor perception in the soil Collembola Onychiurus armatus. Journal of Chemical Ecology, 17(11):2113-2125. doi: 10.1007/BF00987995.

Böllmann J, Elmer M, Wöllecke J, Raidl S, and Hüttl RF, 2010. Defensive strategies of soil fungi to prevent grazing by Folsomia candida (Collembola). Pedobiologia, 53(2):107-114. ISSN 00314056. doi:10.1016/j.pedobi.2009.06.003.

Börjesson T, Stollman U, and Schnurer J, 1992. Volatile metabolites produced by 6 fungal species compared with other indicators of fungal growth on cereal-grains. Applied and Environmental Microbiology, 58(8):2599-2605.

Brand JM, Schultz J, Barras SJ, Edson LJ, Payne TL, and Hedden RL, 1977. Bark-beetle pheromones - enhancement of Dendroctonus frontalis (Coleoptera: Scolytidae) aggregation pheromone by yeast metabolites in laboratory bioassays. Journal of Chemical Ecology, 3(6):657-666. ISSN 00980331. doi:10.1007/BF00988065.

Bruce TJA, Wadhams LJ, and Woodcock CM, 2005. Insect host location: a volatile situation. Trends in Plant Science, 10(6):269-274. ISSN 13601385. doi:10.1016/j.tplants.2005.04.003.

Chapman RF and Bernays EA, 1989. Insect behavior at the leaf surface and learning as aspects of host plant selection. Experientia, 45(3):215-222. ISSN 00144754. doi:10.1007/ BF01951806.

Chen B, Snider R, and Snider R, 1995. Food preferences and effects of food type on the life history of some soil Collembola. Pedobiologia, 39:496-505. 
Cohen J, 1988. Statistical power analysis for the behavioral sciences. Lawrence Erlbaum Associates, Hillsdale, 2 edition. ISBN 0-8058-0283-5.

Combet E, Henderson J, Eastwood DC, and Burton KS, 2009. Influence of sporophore development, damage, storage, and tissue specificity on the enzymic formation of volatiles in mushrooms (Agaricus bisporus). Journal of Agricultural and Food Chemistry, 57(9):3709-3717. ISSN 00218561. doi:10.1021/jf8036209.

Dethier V, Barton Browne L, and Smith C, 1960. The designation of chemicals in terms of the responses they elicit from insects. Journal of Economic Entomology, 53:134-136. doi: 10.1093/jee/53.1.134.

Döll K, Chatterjee S, Scheu S, Karlovsky P, and Rohlfs M, 2013. Fungal metabolic plasticity and sexual development mediate induced resistance to arthropod fungivory. Proceedings of the Royal Scociety B, 280(1771):20131219. ISSN 1471-2954. doi:10.1098/rspb.2013.1219.

Dowd PF and Bartelt RJ, 1991. Host-derived volatiles as attractants and pheromone synergists for driedfruit beetle Carpophilus hemipterus. Journal of Chemical Ecology, 17(2):285-308. doi:10.1007/BF00994333.

Drilling K and Dettner K, 2009. Electrophysiological responses of four fungivorous coleoptera to volatiles of Trametes versicolor: implications for host selection. Chemoecology, 19(2):109-115. ISSN 09377409. doi:10.1007/s00049-009-0015-9.

Fäldt J, Jonsell M, Nordlander G, and Borg-Karlson AK, 1999. Volatiles of bracket fungi Fomitopsis pinicola and Fomes fomentarius and their functions as insect attractants. Journal of Chemical Ecology, 25(3):567-590. doi:10.1023/ A:1020958005023.

Fiedler K, Schütz E, and Geh S, 2001. Detection of microbial volatile organic compounds (MVOCs) produced by moulds on various materials. International Journal of Hygiene and Environmental Health, 204(2-3):111-121. ISSN 1438-4639. doi:10.1078/1438-4639-00094.

Halitschke R, Ziegler J, Keinänen M, and Baldwin IT, 2004. Silencing of hydroperoxide lyase and allene oxide synthase reveals substrate and defense signaling crosstalk in Nicotiana attenuata. Plant Journal, 40(1):35-46. ISSN 09607412. doi:10.1111/j.1365-313X.2004.02185.x.

Handa L, Smith M, Nigam I, and Lev L, 1964. Essential oils and their constituents 23. Chemotaxonomy of the genus Mentha. Journal of Pharmaceutical Sciences, 53(11):1407-1409.

Hanski I, 1989. Fungivory: fungi, insects and ecology. In N Wilding, N Collins, P Hammond, and J Webber, editors, Insect-fungus interactions, pages 25-68. Academic Press, London.

Haubert D, Pollierer MM, and Scheu S, 2011. Fatty acid patterns as biomarker for trophic interactions: changes after dietary switch and starvation. Soil Biology and Biochemistry, 43(3):490-494. ISSN 00380717. doi:10.1016/j.soilbio.2010.10.008.

Heděnec P, Radochová P, Nováková A, Kaneda S, and Frouz J, 2013. Grazing preference and utilization of soil fungi by Folsomia candida (Isotomidae: Collembola). European Journal of Soil Biology, 55:66-70. ISSN 11645563. doi:10.1016/j.ejsobi.2012.12.005.

Hedlund K, Bengtsson G, and Rundgren S, 1995. Fungal odour discrimination in two sympatric species of fungivorous collembolans. Functional Ecology, 9(6):869-875. ISSN 02698463. doi: $10.2307 / 2389984$. 
Heil M, 2014. Herbivore-induced plant volatiles: targets, perception and unanswered questions. Journal of Physiology, 204(2):297-306. ISSN 14697793. doi:10.1111/nph.12977.

Hernández-Oñate MA and Herrera-Estrella A, 2015. Damage response involves mechanisms conserved across plants, animals and fungi. Current Genetics, 61(3):359-372. ISSN 14320983. doi:10.1007/s00294-014-0467-5.

Hiol Hiol F, Dixon RK, and Curl EA, 1994. The feeding preference of mycophagous Collembola varies with the ectomycorrhizal symbiont. Mycorrhiza, 5(2):99-103. ISSN 09406360. doi:10.1007/BF00202340.

Holighaus G, Weißbecker B, von Fragstein M, and Schütz S, 2014. Ubiquitous eight-carbon volatiles of fungi are infochemicals for a specialist fungivore. Chemoecology, 24(2):57-66. ISSN 09377409. doi:10.1007/s00049-014-0151-8.

Hopkin S, 1997. The biology of the Collembola (springtails): the most abundant insects in the world. Natural History Museum, London. ISBN 0198540841.

Hulcr J, Mann R, and Stelinski LL, 2011. The scent of a partner: ambrosia beetles are attracted to volatiles from their fungal symbionts. Journal of Chemical Ecology, 37(12):1374-1377. ISSN 00980331. doi:10.1007/s10886-011-0046-x.

Ihnen K and Zimmer M, 2008. Selective consumption and digestion of litter microbes by Porcellio scaber (Isopoda: Oniscidea). Pedobiologia, 51(5-6):335-342. ISSN 00314056. doi: 10.1016/j.pedobi.2007.06.001.

Jørgensen HB, Johansson T, Canbäck B, Hedlund K, and Tunlid A, 2005. Selective foraging of fungi by collembolans in soil. Biology Letters, 1(2):243-6. ISSN 1744-9561. doi:10.1098/ rsbl.2004.0286.

Kihara H, Tanaka M, Yamato KT, Horibata A, Yamada A, Kita S, Ishizaki K, Kajikawa M, Fukuzawa H, Kohchi T, Akakabe Y, and Matsui K, 2014. Arachidonic acid-dependent carbon-eight volatile synthesis from wounded liverwort (Marchantia polymorpha). Phytochemistry, 107:42-49. ISSN 00319422. doi:10.1016/j.phytochem.2014.08.008.

Korpi A, Jarnberg J, and Pasanen AL, 2009. Microbial volatile organic compounds. Critical Reviews in Toxicology, 39(2):139-193. ISSN 1040-8444. doi:10.1080/10408440802291497.

Maraun M, Martens H, Migge S, Theenhaus A, and Scheu S, 2003. Adding to 'the enigma of soil animal diversity': fungal feeders and saprophagous soil invertebrates prefer similar food substrates. European Journal of Soil Biology, 39(2):85-95. ISSN 11645563. doi:10.1016/ S1164-5563(03)00006-2.

Matysik S, Herbarth O, and Mueller A, 2008. Determination of volatile metabolites originating from mould growth on wall paper and synthetic media. Journal of Microbiological Methods, 75(2):182-187. doi:10.1016/j.mimet.2008.05.027.

Mburu DM, Maniania NK, and Hassanali A, 2013. Comparison of volatile blends and nucleotide sequences of two Beauveria bassiana isolates of different virulence and repellency towards the termite Macrotermes michealseni. Journal of Chemical Ecology, 39(1):101-108. ISSN 00980331. doi:10.1007/s10886-012-0207-6. 
Mburu DM, Ndung'u MW, Maniania NK, and Hassanali A, 2011. Comparison of volatile blends and gene sequences of two isolates of Metarhizium anisopliae of different virulence and repellency toward the termite Macrotermes michaelseni. Journal of Experimental Biology, 214(6):956-962. ISSN 0022-0949. doi:10.1242/jeb.050419.

Men'ko EV, Chernov II, and Byzov Ba, 2006. Interrelationships between yeast fungi and collembolans in soil. Mikrobiologiia, 75(6):814-822. ISSN 0026-2617. doi:10.1134/ S0026261706060142.

Mitchell BK and McCashin BG, 1994. Tasting green leaf volatiles by larvae and adults of Colorado potato beetle, Leptinotarsa decemlineata. Journal of Chemical Ecology, 20(3):753-69. ISSN 0098-0331. doi:10.1007/BF02059611.

Moore JC, Ingham ER, and Coleman DC, 1987. Inter- and intraspecific feeding selectivity of Folsomia candida (Willem) (Collembola, Isotomidae) on fungi. Biology and Fertility of Soils, 5(1):6-12. ISSN 01782762. doi:10.1007/BF00264338.

Murray R, Martin A, and Stride G, 1972. Identification of the volatile phagostimulants in Solanum campylacanthum for Epilachna fulvosignata. Journal of Insect Physiology, 18:23692373. doi:10.1016/0022-1910(72)90181-3.

Nilsson T, Larsen TO, Montanarella L, and Madsen JO, 1996. Application of head space solid phase microextraction for the analysis of volatiles emitted by Penicillium species. Journal of Microbiological Methods, 25(245-255):245-255.

Noldus LPJJ, 1991. The Observer: a software system for collection and analysis of observational data. Behavior Research Methods, 23(3):415-429. doi:10.3758/BF03203406.

Noldus LPJJ, Spink AJ, and Tegelenbosch RAJ, 2001. EthoVision: a versatile video tracking system for automation of behavioral experiments. Behavior Research Methods, Instruments, $\mathcal{E}$ Computers, 33(3):398-414. ISSN 0743-3808. doi:10.3758/BF03195394.

Nout MJR and Bartelt RJ, 1998. Attraction of a flying nitidulid (Carpophilus humeralis) to volatiles produced by yeasts grown on sweet corn and a corn-based medium. Journal of Chemical Ecology, 24(7):1217-1239. doi:10.1023/A:1022451020013.

Pawliszyn J, 1997. Solid phase microextraction: theory and practice. Wiley-VCH, Inc, New York.

Pierce AM, Pierce HD, Borden JH, and Oehlschlager AC, 1991a. Fungal volatiles: semiochemicals for stored-product beetles (Coleoptera: Cucujidae). Journal of Chemical Ecology, 17(3):581-597. ISSN 00980331. doi:10.1007/BF00982128.

Pierce AM, Pierce HD, Oehlschlager AC, and Borden JH, 1991b. 1-Octen-3-ol, attractive semiochemical for foreign grain beetle, Ahasverus advena (Waltl) (Coleoptera: Cucujidae). Journal of Chemical Ecology, 17(3):567-580. ISSN 00980331. doi:10.1007/BF00982127.

R Development Core Team, 2008. R: a language and environment for statistical computing. www.r-project.org. ISBN 3-900051-07-0.

Rohlfs M, Albert M, Keller NP, and Kempken F, 2007. Secondary chemicals protect mould from fungivory. Biology Letters, 3:523-525. ISSN 1744-9561. doi:10.1098/rsbl.2007.0338.

Rohlfs M and Churchill ACL, 2011. Fungal secondary metabolites as modulators of interactions with insects and other arthropods. Fungal Genetics and Biology, 48(1):23-34. ISSN 10871845. doi:10.1016/j.fgb.2010.08.008. 
Rothe J and Gleixner G, 2000. Do stable isotopes reflect the food web development in regenerating ecosystems? Isotopes in Environmental and Health Studies, 36(3):285-301. ISSN 10256016. doi:10.1080/10256010008036388.

Sadaka-Laulan N, Ponge JF, Roquebert MF, Bury E, and Boumezzough A, 1998. Feeding preferences of the collembolan Onychiurus sinensis for fungi colonizing holm oak litter (Quercus rotundifolia Lam.). European Journal of Soil Biology, 34(4):179-188. ISSN 11645563. doi:10.1016/S1164-5563(00)86660-1.

Sawahata T, Shimano S, and Suzuki M, 2008. Tricholoma matsutake 1-Ocen-3-ol and methyl cinnamate repel mycophagous Proisotoma minuta (Collembola: Insecta). Mycorrhiza, 18(2):111-114. ISSN 09406360. doi:10.1007/s00572-007-0158-x.

Scheu S and Simmerling F, 2004. Growth and reproduction of fungal feeding Collembola as affected by fungal species, melanin and mixed diets. Oecologia, 139(3):347-353. ISSN 00298549. doi:10.1007/s00442-004-1513-7.

Schoenfeld D, 1980. Chi-squared goodness-of-fit tests for the proportional hazards regression model. Biometrika, 67(1):145-153. doi:10.1093/biomet/67.1.145.

Schoenfeld D, 1982. Partial residuals for the proportional hazards regression-model. Biometrika, 69(1):239-241. ISSN 00063444. doi:Doi10.2307/2335876.

Schoonhoven L, 1968. Chemosensory bases of host plant selection. Annual Review of Entomology, 13:115-136. doi:10.1146/annurev.en.13.010168.000555.

Schoonhoven LM, van Loon JJA, and Dicke M, 2005. Insect-plant biology. Oxford University Press, New York, 2 edition. ISBN 978-0-19-852594-3.

Shaw P, 1988. A consistent hierarchy in the fungal feeding preferences of the Collembola Onychiurus armatus. Pedobiologia, 31:179-187.

Speed MP, Ruxton GD, Mappes J, and Sherratt TN, 2012. Why are defensive toxins so variable? An evolutionary perspective. Biological Reviews, 87(4):874-884. ISSN 14647931. doi:10.1111/j.1469-185X.2012.00228.x.

Staaden S, Milcu A, Rohlfs M, and Scheu S, 2011. Olfactory cues associated with fungal grazing intensity and secondary metabolite pathway modulate Collembola foraging behaviour. Soil Biology and Biochemistry, 43(7):1411-1416. ISSN 00380717. doi: 10.1016/j.soilbio.2010.10.002.

Stötefeld L, Scheu S, and Rohlfs M, 2012. Fungal chemical defence alters density-dependent foraging behaviour and success in a fungivorous soil arthropod. Ecological Entomology, 37(5):323-329. ISSN 03076946. doi:10.1111/j.1365-2311.2012.01373.x.

Tabata J, de Moraes CM, and Mescher MC, 2011. Olfactory cues from plants infected by powdery mildew guide foraging by a mycophagous ladybird beetle. PLOS ONE, 6(8):2-7. ISSN 19326203. doi:10.1371/journal.pone.0023799.

Thakeow P, Angeli S, Weissbecker B, and Schütz S, 2008. Antennal and behavioral responses of Cis boleti to fungal odor of Trametes gibbosa. Chemical Senses, 33(4):379-87. ISSN 14643553. doi:10.1093/chemse/bjn005. 
Thimm T and Larink O, 1995. Grazing preferences of some collembola for endomycorrhizal fungi. Biology and Fertility of Soils, 19(2-3):266-268. ISSN 01782762. doi: $10.1007 /$ BF00336171.

Tordoff GM, Boddy L, and Jones TH, 2008. Species-specific impacts of collembola grazing on fungal foraging ecology. Soil Biology and Biochemistry, 40(2):434-442. ISSN 00380717. doi:10.1016/j.soilbio.2007.09.006.

Tsitsigiannis DI and Keller NP, 2007. Oxylipins as developmental and host-fungal communication signals. Trends in Microbiology, 15(3):109-118. ISSN 0966842X. doi:10.1016/j.tim. 2007.01.005.

Vanhaelen M, Vanhaelen-Fastré R, and Geeraerts J, 1980. Occurrence in mushrooms (Homobasidiomycetes) of cis- and trans-octa-1,5-dien-3-ol, attractants to the cheese mite Tyrophagus putrescentiae (Schrank) (Acarina, Acaridae). Experientia, 36:406-407. doi: 10.1007/BF01975114.

Varga J, Naár Z, and Dobolyi C, 2002. Selective feeding of collembolan species Tomocerus longicornis (Müll.) and Orchesella cincta (L.) on moss inhabiting fungi. Pedobiologia, 46:526538. ISSN 00314056. doi:10.1078/0031-4056-00157.

Visser S and Whittaker JB, 1977. Feeding preferences for certain litter fungi by Onychiurus subtenuis (Collembola). Oikos, 29(2):320-325. doi:10.2307/3543621.

Walsh MI and Bolger T, 1990. Effects of diet on the growth and reproduction of some Collembola in laboratory cultures. Pedobiologia, 34(3):161-171. ISSN 0031-4056. doi: 10.1007/s00442-004-1513-7.

Wei J and Kang L, 2011. Roles of (Z)-3-hexenol in plant-insect interactions. Plant Signaling and Behavior, 6(3):369-371. ISSN 15592316. doi:10.4161/psb.6.3.14452.

Wood WF, Archer CL, and Largent DL, 2001. 1-Octen-3-ol, a banana slug antifeedant from mushrooms. Biochemical Systematics and Ecology, 29(5):531-533. ISSN 03051978. doi:10. 1016/S0305-1978(00)00076-4.

Wurzenberger M and Grosch W, 1983. Bestimmung von 1-Octen-3-ol in Pilzen und Pilzprodukten. Zeitschrift für Lebensmitteluntersuchung und -Forschung A, 25:567-590. doi: 10.1007/BF01089340.

Yaws C, 2007. The Yaws handbook of vapor pressure: Antoine coefficients. Gulf Publishing Company, 1 edition.

Yin W, Amaike S, Wohlbach D, Gasch A, Chiang Y, Wang C, Bok J, Rohlfs M, and Keller N, 2012. An Aspergillus nidulans bZIP response pathway hardwired for defensive secondary metabolism operates through aflR. Molecular Microbiology, 83:1024-1034. doi:10.1111/j. 1365-2958.2012.07986.x.

Zhang Y, 2016. Spatial differences in (Z)-3-hexen-1-ol production preferentially reduces Spodoptera litura larva attack on the young leaves of Nicotiana benthamiana. Plant Science, 252:367-373. doi:10.1016/j.plantsci.2016.08.016.

Zirbes L, Mescher M, Vrancken V, Wathelet JP, Verheggen FJ, Thonart P, and Haubruge E, 2011. Earthworms use odor cues to locate and feed on microorganisms in soil. PLoS ONE, 6(7):1-7. ISSN 19326203. doi:10.1371/journal.pone.0021927. 


\section{APPENDIX}

Table A.2.1: Analytical response (TIC peak area) to authentic compounds 3-octanone (3OCT), 3-octyl acetate (3OcAc), and 3-methyl-1-butanol (IA) diluted with paraffin at four concentrations (conc) and equivalent headspace concentrations in $\mathrm{ng} / \mathrm{cm}^{3}$ (calibration plots: Figure A.2.1)

\begin{tabular}{ccccccccc}
\hline $\begin{array}{c}3 O C T \\
\text { conc }\end{array}$ & $\begin{array}{c}3 O C T \\
\mathrm{ng} / \mathrm{cm}^{3}\end{array}$ & $\begin{array}{c}3 O C T \\
\text { TIC peak area }\end{array}$ & $\begin{array}{c}3 O c A c \\
\text { conc }\end{array}$ & $\begin{array}{c}3 O c A c \\
\mathrm{ng} / \mathrm{cm}^{3}\end{array}$ & $\begin{array}{c}3 O c A c \\
\text { TIC peak area }\end{array}$ & $\begin{array}{c}I A \\
\text { conc }\end{array}$ & $\begin{array}{c}I A \\
\mathrm{ng} / \mathrm{cm}^{3}\end{array}$ & $\begin{array}{c}I A \\
\text { TIC peak area }\end{array}$ \\
\hline 0.0000001 & 0.0012 & 164135 & 0.0000001 & 0.000319 & 1092643 & 0.000000001 & 0.00000672 & 756273 \\
0.000001 & 0.012 & 3026680 & 0.000001 & 0.00319 & 1927189 & 0.00000001 & 0.0000672 & 9065576 \\
0.00001 & 0.12 & 58245454 & 0.00001 & 0.0319 & 22114012 & 0.0000001 & 0.000672 & 53654625 \\
0.0001 & 1.2 & 465265131 & 0.0001 & 0.319 & 115522300 & 0.000001 & 0.00672 & 404864832 \\
\hline
\end{tabular}

Table A.2.2: Presence (black circle) and absence (white circle) of volatile compounds identified from headspace samples of unwounded (uw) and wounded (wo) C. globosum colonies (CG) and fungal-free MEA controls. Compound identities were verified by matching experimental retention indices $\left(R I_{\mathrm{ex}}\right)$ with literature values $\left(R I_{L i}\right)$ and authentic compounds $\left(R I_{A c}\right)$. Compound numbers correspond to peak numbers in total ion current chromatograms Figure A.2.2

\begin{tabular}{|c|c|c|c|c|c|c|c|c|c|}
\hline$\#$ & Compound name & CAS & $\begin{array}{c}\text { MEA } \\
\text { control }\end{array}$ & $\begin{array}{c}C G \\
\text { unwounded }\end{array}$ & $\begin{array}{c}C G \\
\text { wounded }\end{array}$ & $R I_{e x}{ }^{1}$ & $R I_{L i}^{2}$ & $R I_{A C}^{3}$ & Reference \\
\hline 1 & $\mathrm{CO} 2$ & $124-38-9$ & $\bullet$ & $\bullet$ & $\bullet$ & - & - & - & - \\
\hline 3 & Ethanol & $64-17-5$ & $\bullet$ & $\bullet$ & $\bullet$ & 479 & 446 & - & Peng (1992) \\
\hline 4 & Furan & $110-00-9$ & $\bullet$ & $\bullet$ & $\bullet$ & 502 & - & - & - \\
\hline 6 & 2-propanol & $67-63-0$ & $\bullet$ & $\bullet$ & $\bullet$ & 524 & 516 & - & Xu et al. (2003) \\
\hline 7 & 1-propanol & $71-23-8$ & $\bullet$ & $\bullet$ & $\bullet$ & 588 & 595 & - & Bylaite \& Meyer (2006) \\
\hline 8 & 2-butanone & $78-93-3$ & $\bullet$ & $\bullet$ & $\bullet$ & 604 & 603 & - & Madruga \& Mottram (1998) \\
\hline 9 & 2-methylfuran & $534-22-5$ & $\bullet$ & $\bullet$ & $\bullet$ & 608 & 605 & - & Methven et al. (2007) \\
\hline 10 & 5-methyl-3-heptanone & $541-85-5$ & $\bullet$ & $\bullet$ & $\bullet$ & 943 & 939 & - & Rostad \& Pereiran (1986) \\
\hline 13 & 3-methylbutanal & $590-86-3$ & $\bullet$ & ○ & ○ & 662 & 664 & - & Bylaite \& Meyer (2006) \\
\hline 14 & 2-methylbutanal & $96-17-3$ & $\bullet$ & O & O & 668 & 664 & - & Rychlik \& Bosset (2001) \\
\hline 15 & Hexanal & $66-25-1$ & $\bullet$ & O & ○ & 803 & 803 & - & Wu \& Cadwallader (2002) \\
\hline 16 & Isoamyl alcohol & $123-51-3$ & ○ & $\bullet$ & $\bullet$ & 745 & 750 & 745 & Komárek (1998) \\
\hline 17 & 3-octanone & $106-68-3$ & ○ & $\bullet$ & $\bullet$ & 988 & 988 & 988 & Javidnia (2005) \\
\hline 18 & 3-octyl acetate & $4864-61-3$ & ○ & $\bullet$ & $\bullet$ & 1126 & 1127 & 1126 & Andriamaharavo (2014) \\
\hline
\end{tabular}

Van den Dool and Kratz retention indices as ${ }^{1}$ calculated from experimental retention times ${ }^{2}$ reported in literature (see Reference) and ${ }^{3}$ calculated from authentic compound 
(a)

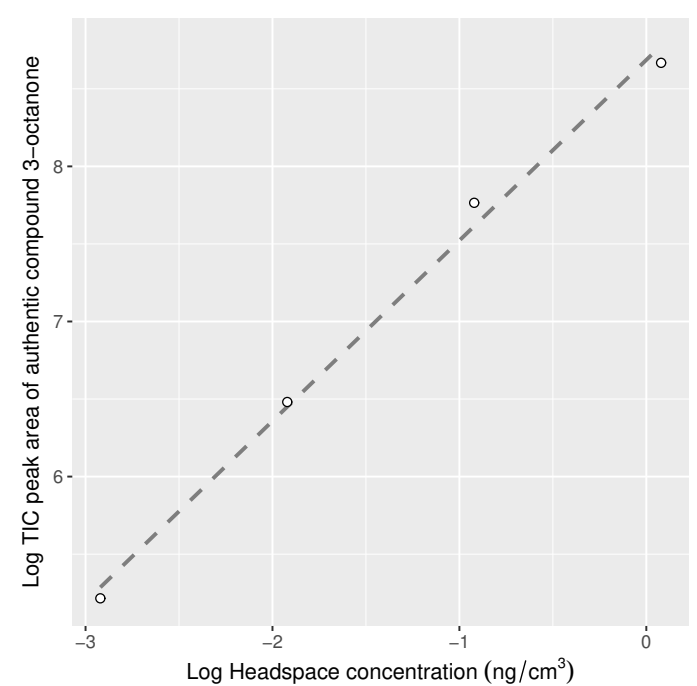

(b)

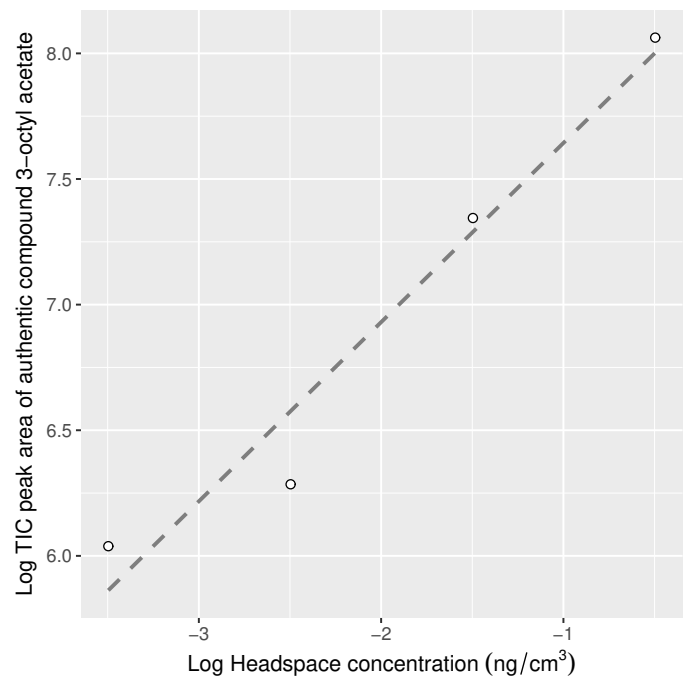

(c)

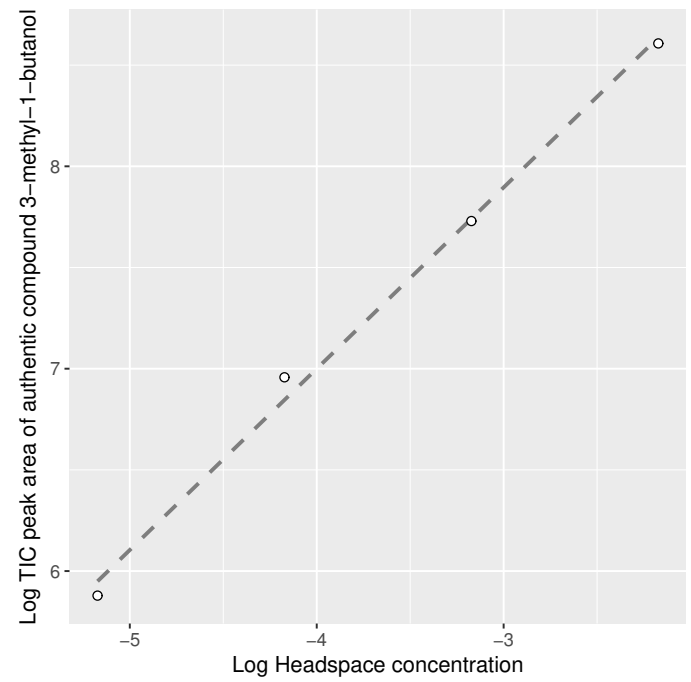

Figure A.2.1: Logarithmic calibration plots with linear trend line (dotted, grey) representing analytical response (TIC peak area) as a function of known analyte quantity $\left(\mathrm{ng} / \mathrm{cm}^{3}\right)$ for authentic volatile compounds (a) 3-octanone (adjusted $R^{2}=0.9999$, intercept $=3067321.94$, slope $=385918297.55, p=0.0031$ ), b 3-octyl acetate (adjusted $R^{2}=0.9997$, intercept $=4009911.35$, slope $\left.=351864015.66, p=0.0059\right)$, and (c) 3-methyl-1-butanol (adjusted $R^{2}=0.9998$, intercept $=6131182.63$, slope $=59437062504.38, p=0.0048$ ). Respective linear model estimates were used for quantification of headspace concentrations of $\mathrm{C}$. globosum fungal volatiles. 
(a)

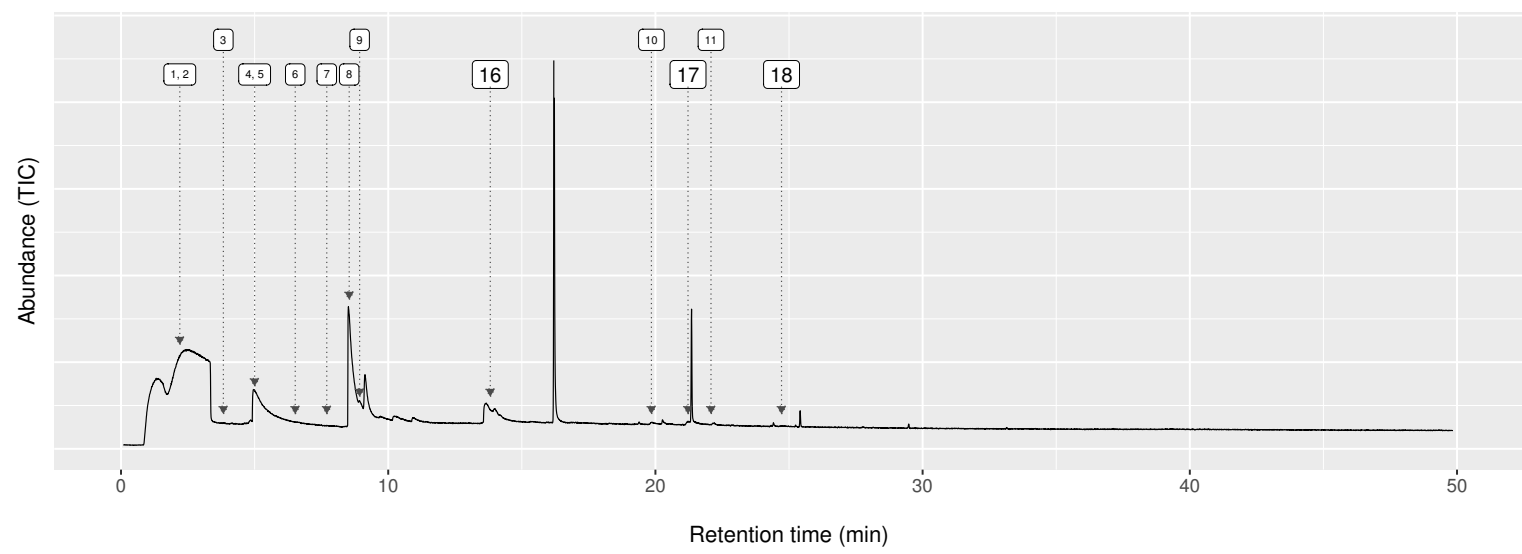

(b)

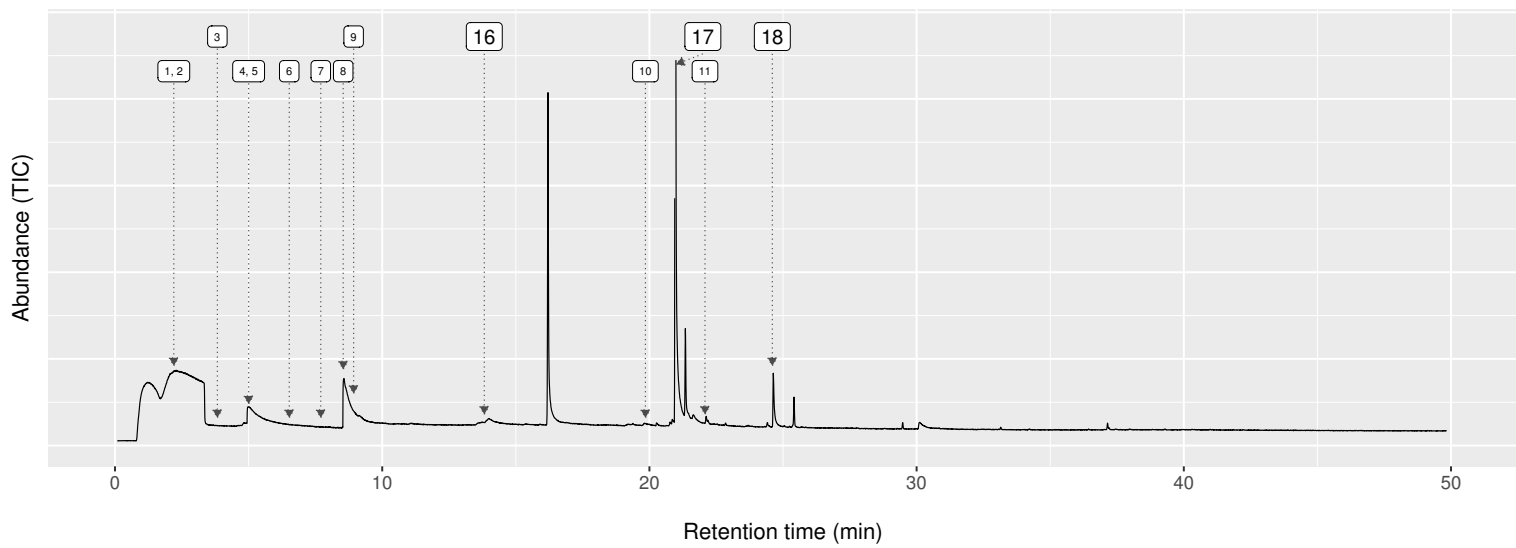

(c)

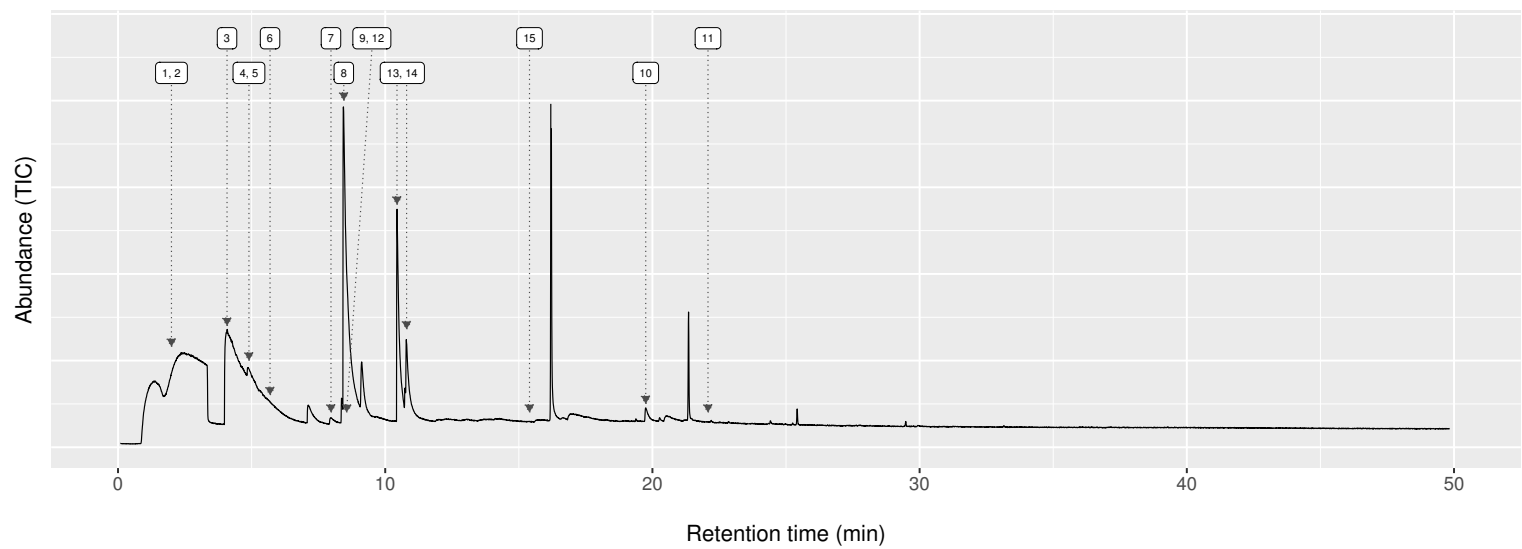

Figure A.2.2: Total ion current chromatograms of (a) unwounded and [b] wounded C. globosum colonies, and (c) fungal-free MEA controls. Peak numbers correspond to compound numbers in Table A.2.2 
(a)

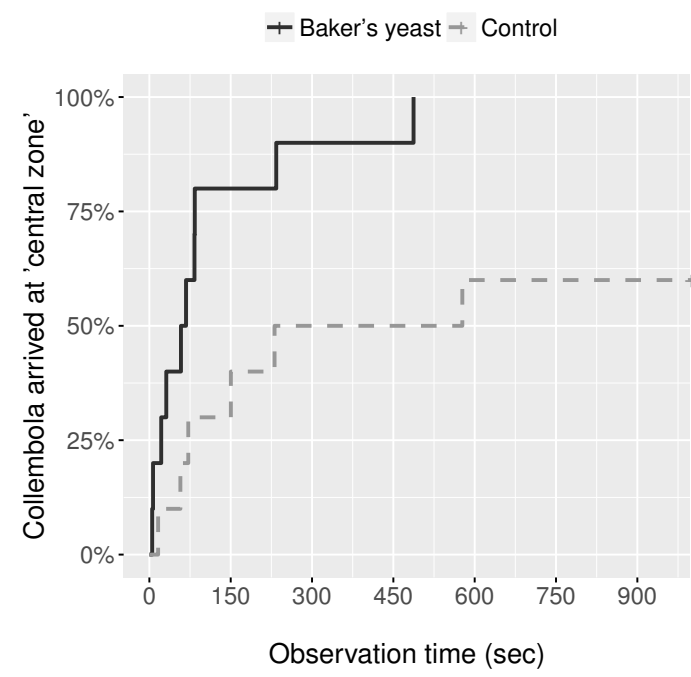

(c)

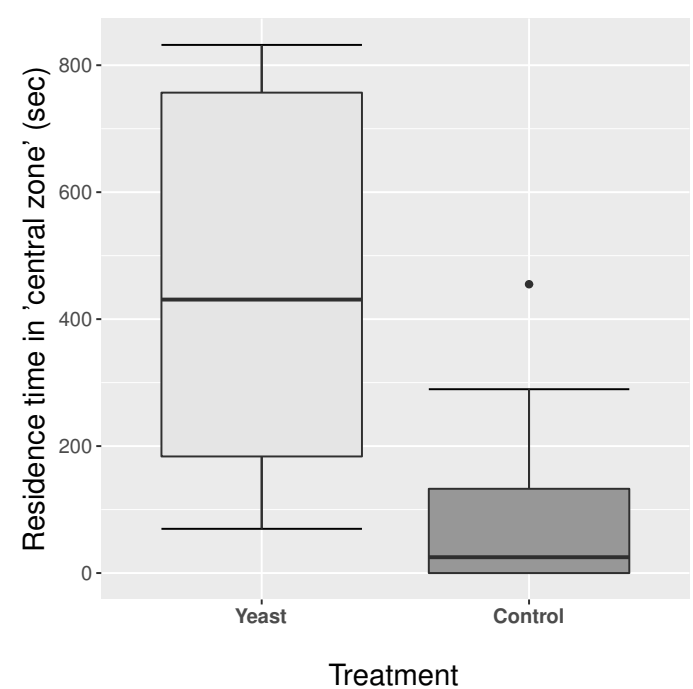

(b)

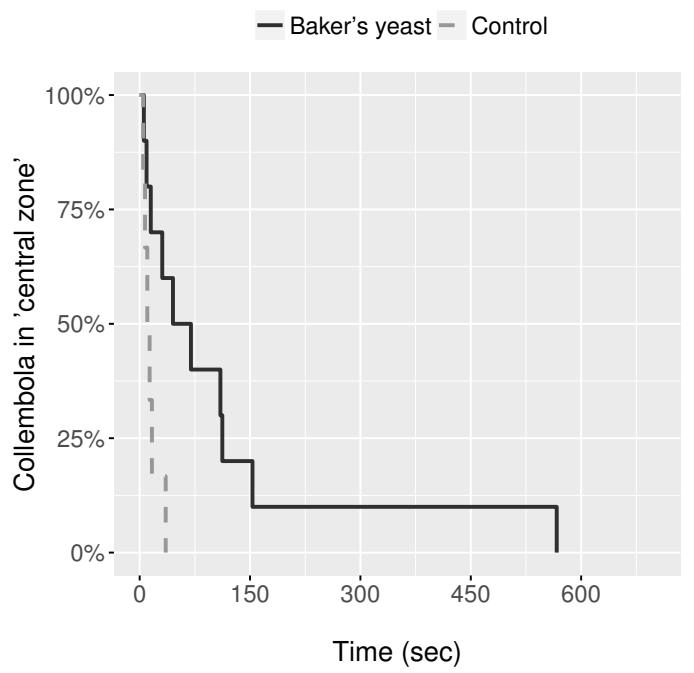

(d)

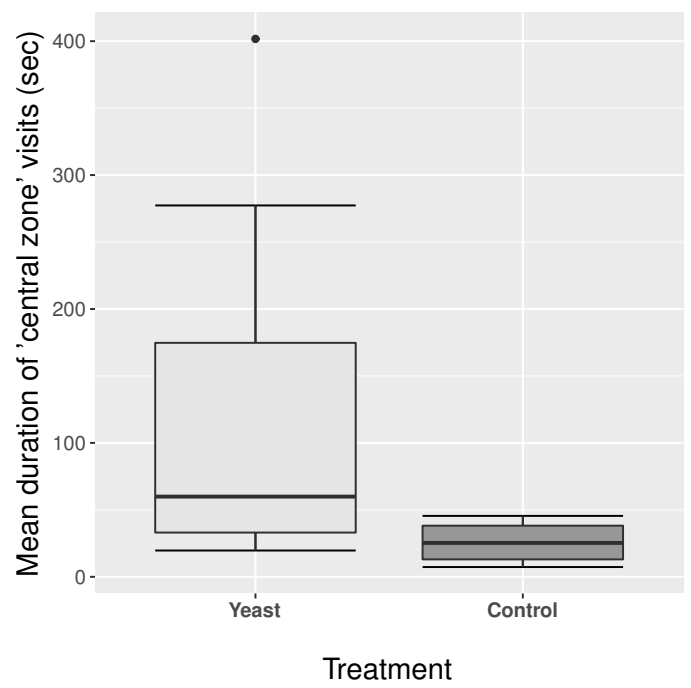

Figure A.2.3: Verification of no-choice olfactometer arena functioning for the detection of Collembola attracting or arresting volatile sources by comparison of individual F. candida responses to the known attractive volatile source dried baker's yeast (applied on the surface of malt extract agar) and yeast free malt extract agar controls within an observation period of 15 minutes. (a) Kaplan-Meier curves for the 'latency to the first arrival at the central zone', (b) 'duration of the first central zone visit', (c) 'residence time in the central zone', and (d) 'mean duration of central zone visits'. Statistical analysis validated arena functioning as arrival tendency of Collembola was significantly higher in response to baker's yeast samples compared to controls (Cox regression, likelihood ratio test: $\tilde{\chi}^{2}=5.91, d f=1, p=0.015$, $\exp (\operatorname{coef})=3.715, N=20$, arrivals=16), indicating attraction. Higher 'residence time in the central zone' (Exact Wilcoxon-Mann-Whitney test: Cohen's $d=1.5, z=3.04, p=0.001$ ), 'mean duration of central zone visits' (Exact Wilcoxon-Mann-Whitney test: Hedge's g=0.89, $z=2.17, p=0.031$ ) and prolonged first 'central zone' visit in response to baker's yeast (Cox regression, likelihood ratio test: $\tilde{\chi}^{2}=5.11, d f=1, p=0.024$, $\exp (\operatorname{coef})=4.431, N=16$, departures $=16)$ indicate arrestance. 
(a)

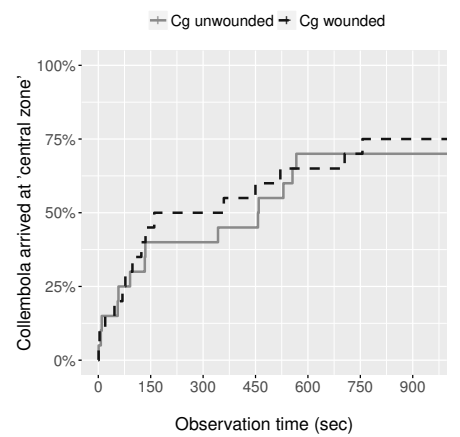

(b)

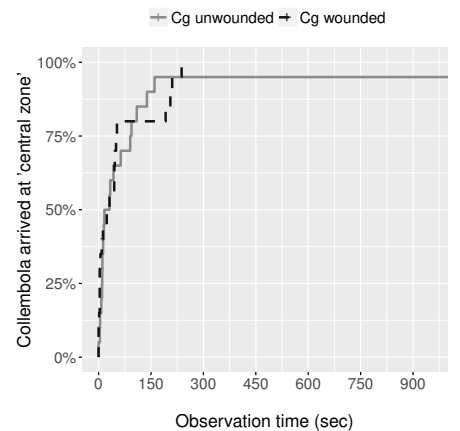

(c)

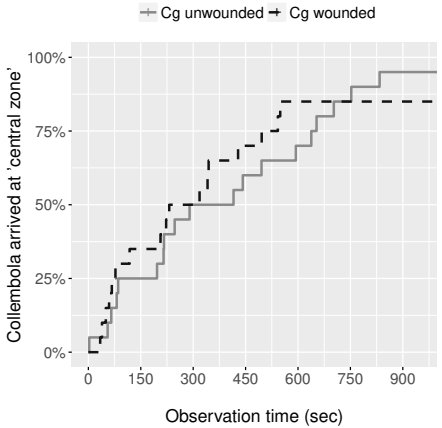

Figure A.2.4: Searching phase: Kaplan-Meier curves for the 'latency to the first arrival at central zones' in response to unwounded and wounded C. globosum colonies $(n=20)$ within an observation period of 15 minutes. (a) F. candida: $p=0.723$; (b) H. nitidus: $p=0.859$; (c) S. curviseta: $p=0.854$.

(a)

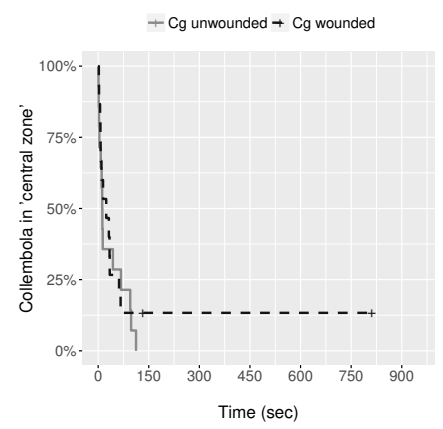

(b)

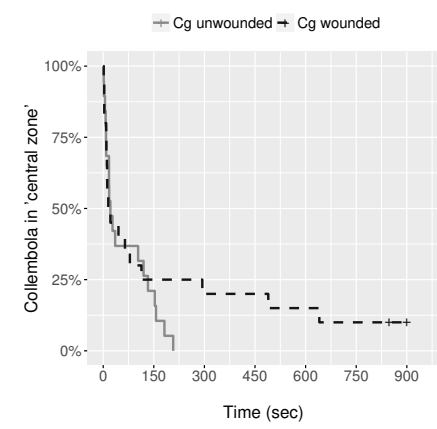

(c)

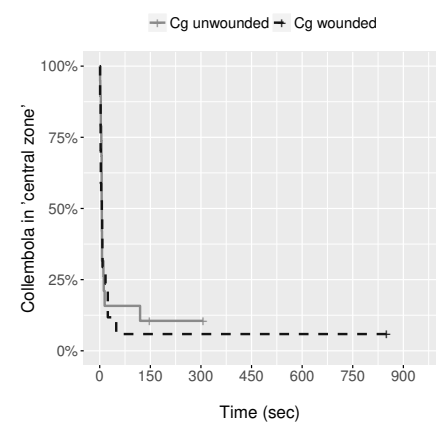

Figure A.2.5: Searching phase: Kaplan-Meier curves for the 'duration of the first central zone visit' (departure tendency) in response to unwounded and wounded C. globosum colonies within an observation period of 15 minutes. (a) F. candida: $p=0.747, N=29$; (b) H. nitidus: $p=0.879, N=39$; (c) S. curviseta: $p=0.731, N=36$.

(a)

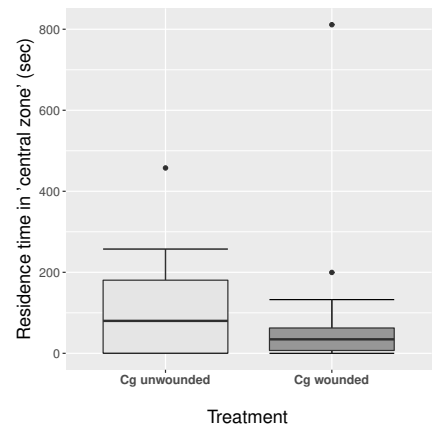

(b)

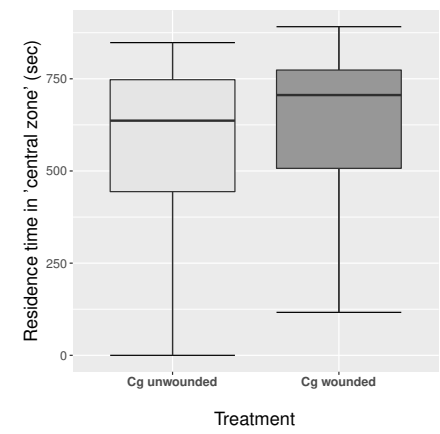

(c)

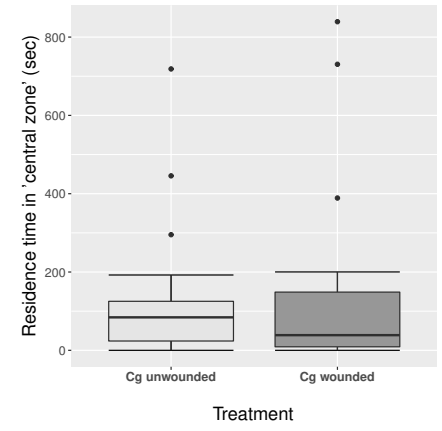

Figure A.2.6: Searching phase: 'Residence time in the central zone' in response to unwounded and wounded C. globosum colonies $(n=20)$ within an observation period of 15 minutes. (a) F. candida: $p=0.276$; (b) H. nitidus; $p=0.925$; (c) S. curviseta: $p=0.499$. 
(a)

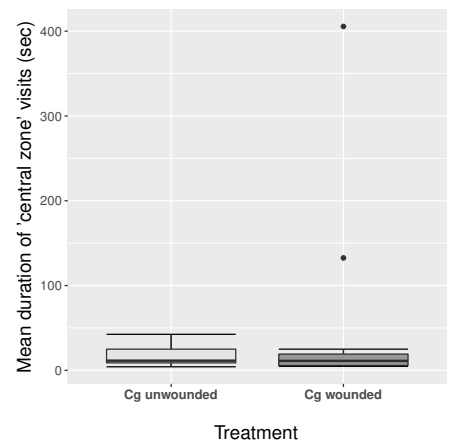

(b)

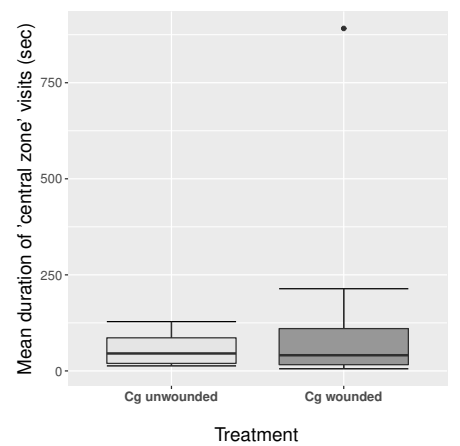

(c)

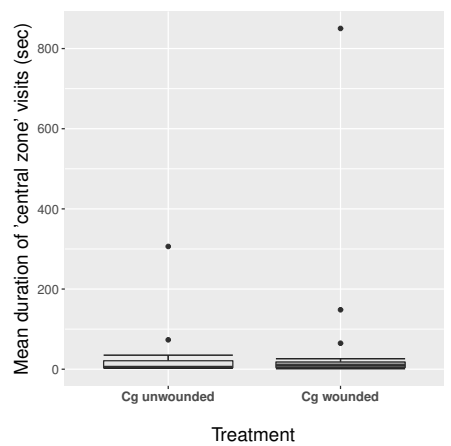

Figure A.2.7: Searching phase: 'Mean duration of central zone visits' in response to unwounded and wounded C. globosum colonies within an observation period of 15 minutes. (a) F. candida: $p=0.908, N=29$; (b) H. nitidus: $p=0.425, N=39$; (c) S. curviseta: $p=0.825, N=36$.

(a)

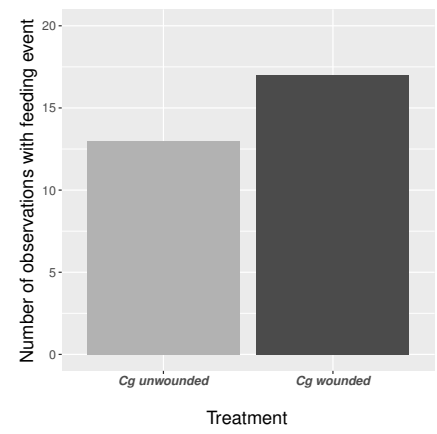

(b)

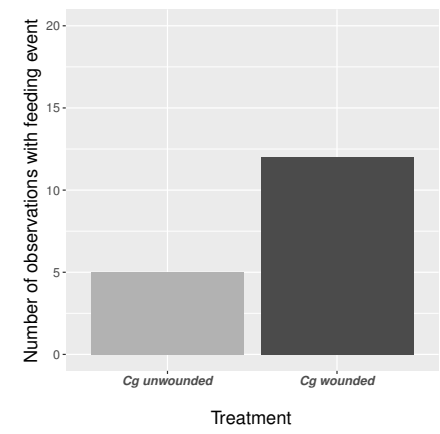

(c)

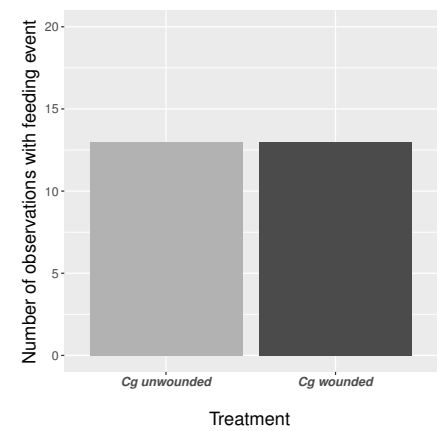

Figure A.2.8: Contact phase: 'Total number of feeding events' in response to unwounded and wounded C. globosum colonies ( $n=20)$. (a) F. candida: $p=0.140$; (b) H. nitidus: $p=0.023$; (c) S. curviseta: $p=0.1$.

(a)

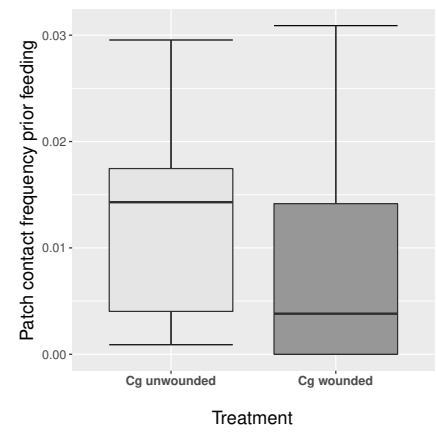

(b)

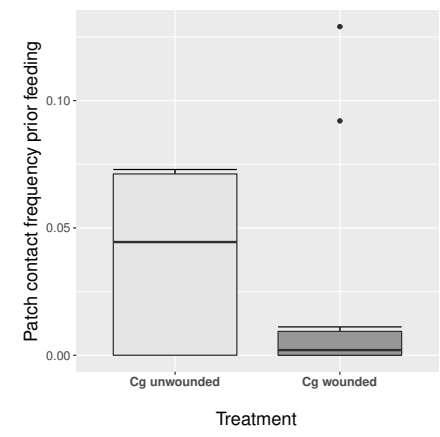

(c)

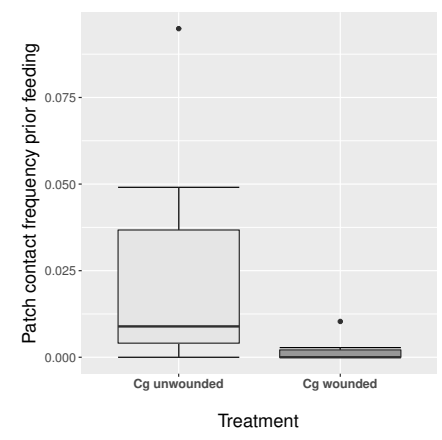

Figure A.2.9: Contact phase: 'Colony contact frequency prior to the first feeding event' in response to unwounded and wounded C. globosum colonies. (a) F. candida: $n_{\text {unwounded }}=13, n_{\text {wounded }}=17, p=0.070$; (b) H. nitidus: $n_{\text {unwounded }}=5, n_{\text {wounded }}=12, p=0.532$; (c) S. curviseta: $n_{\text {unwounded }}=13, n_{\text {wounded }}=13, p=0.004$. 
(a)

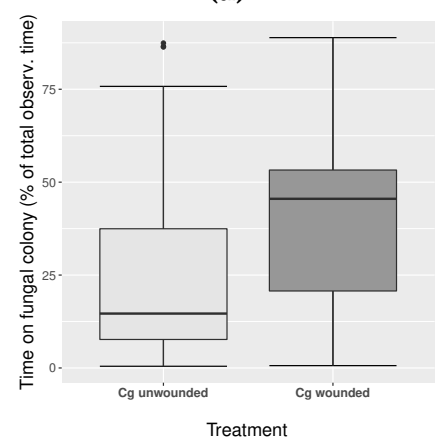

(b)

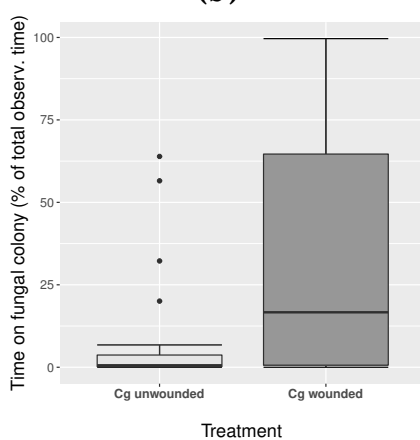

(c)

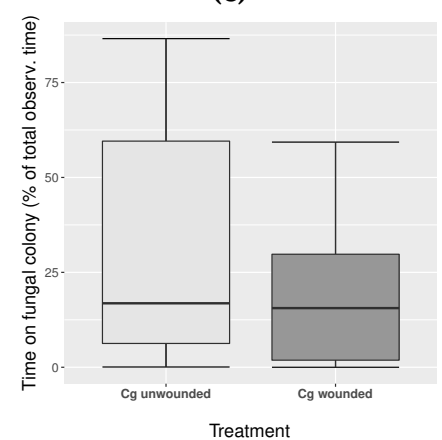

Figure A.2.10: Contact phase: 'Contact time' (\% of total observation time) in response to unwounded and wounded C. globosum colonies ( $n=20)$. (a) F. candida: $p=0.102$; (b) H. nitidus: $p=0.040$; (c) S. curviseta: $p=0.280$.

(a)

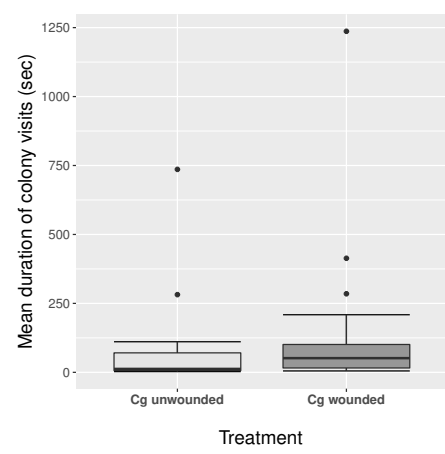

(b)

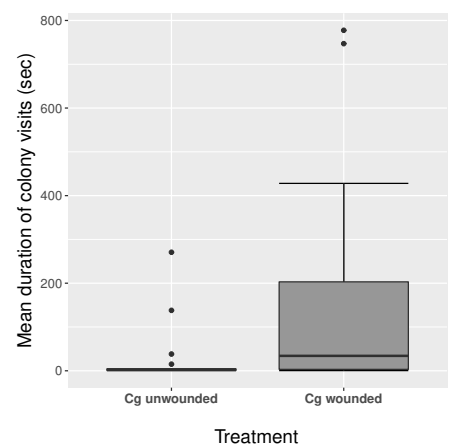

(c)

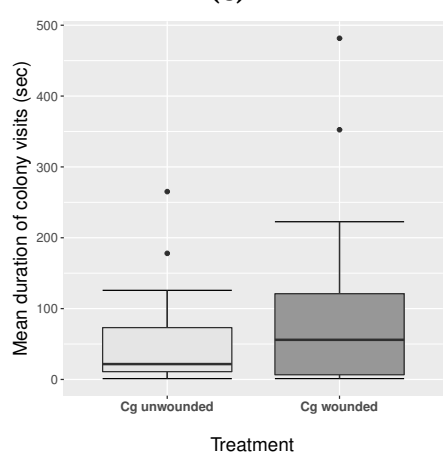

Figure A.2.11: Contact phase: 'Mean duration of colony contacts' in response to unwounded and wounded C. globosum colonies. (a) F. candida: $n_{\text {unwounded }}=20, n_{\text {wounded }}=20, p=0.043$; (b) H. nitidus: $n_{\text {unwounded }}=17$, $n_{\text {wounded }}=18, p=0.019 ;$ (c) S. curviseta: $n_{\text {unwounded }}=20, n_{\text {wounded }}=18, p=0.534$.

(a)

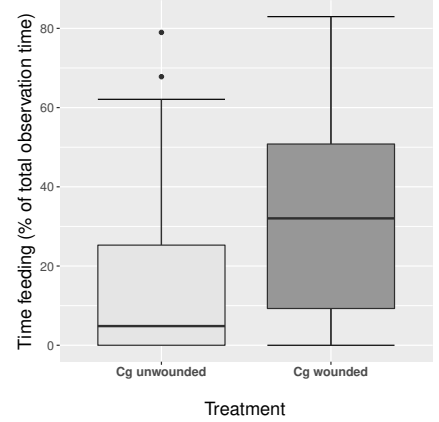

(b)

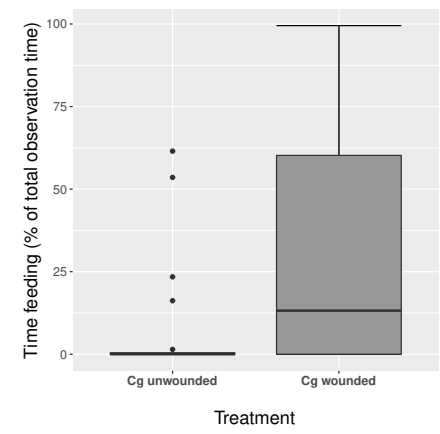

(c)

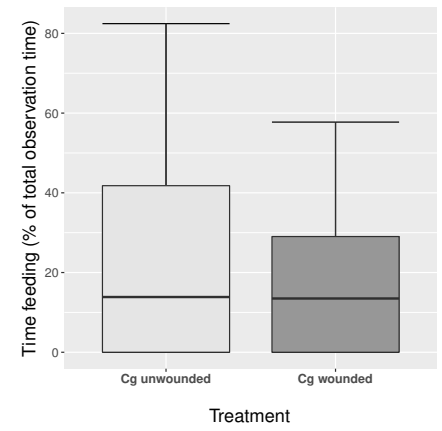

Figure A.2.12: Contact phase: 'Feeding time' (\% of total observation time) in response to unwounded and wounded C. globosum colonies $(n=20)$. (a) F. candida: $p=0.055$; (b) H. nitidus: $p=0.013$; (c) S. curviseta: $p=0.637$. 
(a)

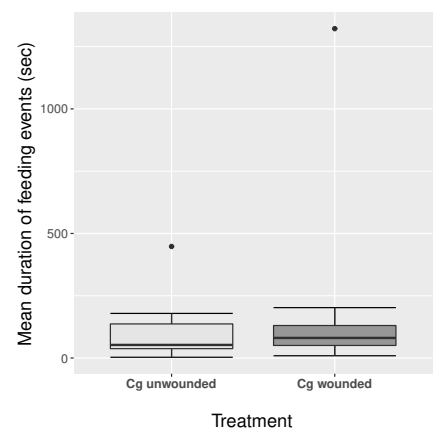

(b)

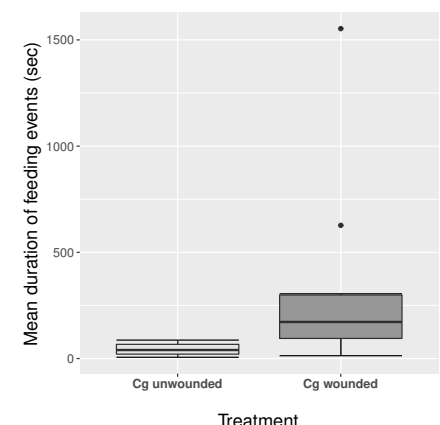

(c)

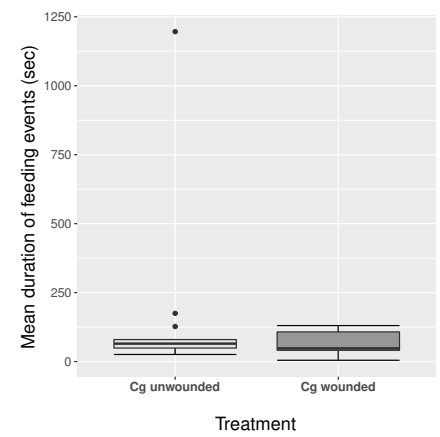

Figure A.2.13: Contact phase: 'Mean duration of feeding events' in response to unwounded and wounded C. globosum colonies. (a) F. candida: $n_{\text {unwounded }}=13, n_{\text {wounded }}=17, p=0.483$; (b) H. nitidus: $n_{\text {unwounded }}=5$, $n_{\text {wounded }}=12, p=0.027 ;$ (c) S. curviseta: $n_{\text {unwounded }}=13, n_{\text {wounded }}=13, p=0.479$.

(a)

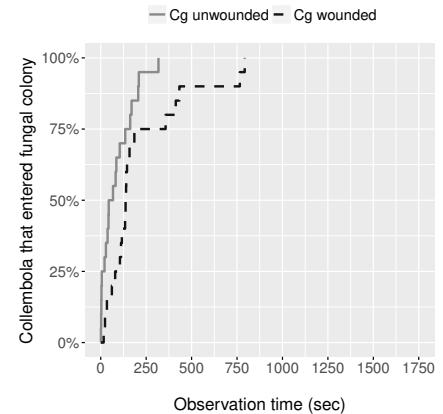

(b)

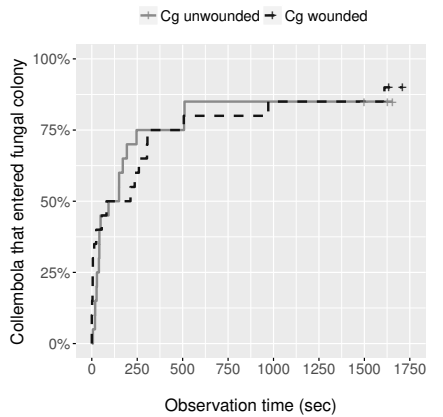

(c)

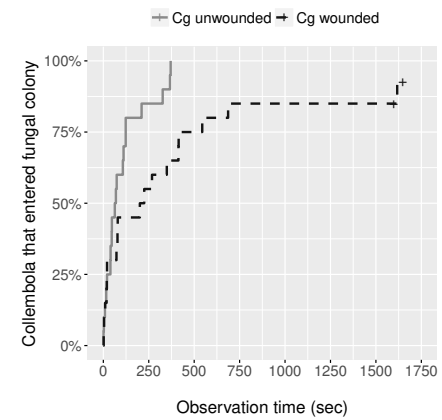

Figure A.2.14: Contact phase: Kaplan-Meier curves for the 'latency to the first colony contact' in response to unwounded and wounded C. globosum colonies $(n=20)$ within an observation period of $\sim 28$ minutes. (a) F. candida: $p=0.022$; (b) H. nitidus: $p=0.849$; (c) S. curviseta: $p=0.014$.

(a)

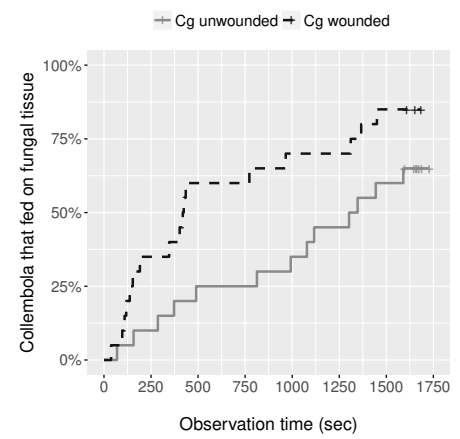

(b)

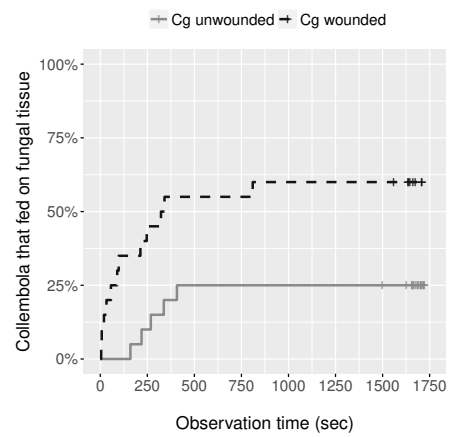

(c)

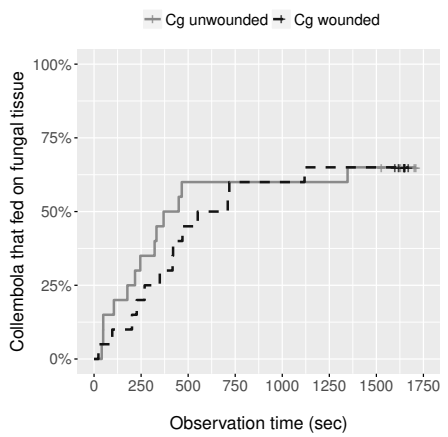

Figure A.2.15: Contact phase: Kaplan-Meier curves for the 'latency to the first feeding event' in response to unwounded and wounded C. globosum colonies $(n=20)$ within an observation period of $\sim 28$ minutes. (a) F. candida: $p=0.047$; (b) H. nitidus: $p=0.022 ;$ (c) S. curviseta: $p=0.692$. 
(a)

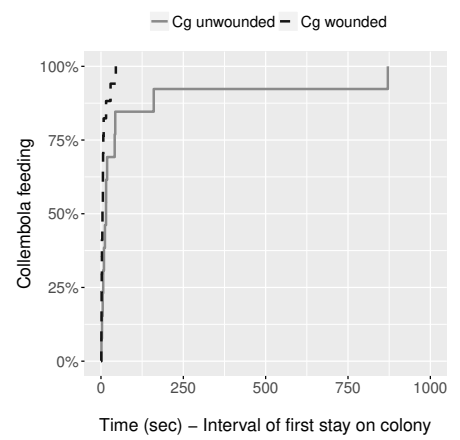

(b)

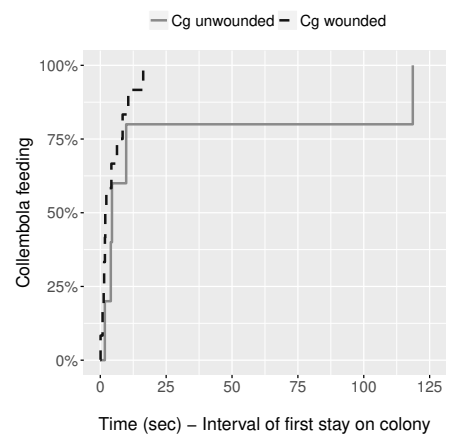

(c)

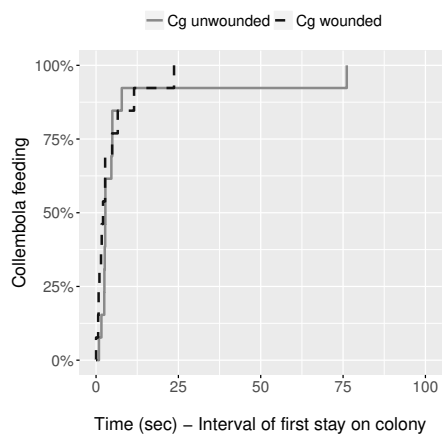

Figure A.2.16: Contact phase: Kaplan-Meier curves for the 'feeding onset latency after the first colony contact' in response to unwounded and wounded C. globosum colonies. Observations without feeding event were excluded. (a) F. candida: $n_{\text {unwounded }}=13, n_{\text {wounded }}=17, p=0.021$; (b) H. nitidus: $n_{\text {unwounded }}=5, n_{\text {wounded }}=12, p=0.263$; (c) S. curviseta: $n_{\text {unwounded }}=13, n_{\text {wounded }}=13, p=0.452$. 


\section{CHAPTER}

\section{FUNGAL VOLATILES MODULATE THE SPATIAL FORAGING BEHAVIOUR OF THE COMMON WOODLOUSE (Oniscus asellus)}

\subsection{Abstract}

As litter-feeders and keystone predators of fungi, isopods significantly contribute to decomposition processes in terrestrial ecosystems. Isopods preferentially feed on microbecolonised pre-decomposed litter and the presence of microorganisms is assumed to indicate the presence of high-quality, viz. cellulose-rich and easily digestible, food sources. The location and selection of microbe-colonised litter has been suggested to be driven by microbial non-volatile and/or volatile chemical cues. By using an isopod-fungus model system Oniscus asellus, Chaetomium globosum - and a direct observational video-tracking approach, this study focuses on the influence of fungal-derived volatiles on the spatial foraging behaviour of isopods. It was hypothesised that isopods use fungal volatiles as infochemicals to locate food from a distance, and that a wound-activated increase in oxylipin volatiles, e.g. 3-octanone, further increases attraction of isopods to their fungal diet. By analysing individual movement patterns, I found that isopods were attracted to and arrested by C. globosum volatiles. Wounding of fungal tissue, however, did not change the behaviour of isopods. Using common metabolites emitted by C. globosum, 3-octanone and 3-methyl-1-butanol, I show that fungal volatiles may influence isopod foraging patterns by acting as arrestants and/or repellents. However, effects of the single compounds did not explain the observed attraction of isopods to fungal colonies. The results support the hypothesis that isopods use fungal volatiles during foraging and may serve as a conceptual starting point for better understanding the complexity and dynamics of such infochemicals in the searching and feeding decisions of this important group of terrestrial crustaceans in decomposer systems.

Keywords: crustacean, fungus-arthropod interaction, attraction, arrestance, infochemicals, volatile organic compounds, oxylipins, 3-octanone, 3-methyl-1-butanol 


\subsection{INTRODUCTION}

Known as generalist detritivores and important decomposers in soil ecosystems, isopods use a variety of different food sources, although plant litter makes up the major part of their diet Abd El-Wakeil 2015, Carefoot 1993, Hassall and Rushton 1984, Hassall et al. 1987, Warburg 1987). While the direct contribution of isopod grazing to decomposition processes via physical and chemical modification of plant material is rather low, a strong indirect contribution via the stimulation of microbial growth has been suggested (Hassall et al.1987).

Isopods preferentially feed on leaf-litter that is colonised by fungi (Gunnarsson 1987, Hassall and Rushton 1984, Soma and Saito 1983, Stöckli 1990, Zidar et al. 2003) and the presence of microorganisms - bacteria and fungi - increases the attractivity of plant litter (Ihnen and Zimmer 2008). Moreover, isopods can differentiate between litter-colonising fungi and show selective feeding (Kayang et al. 1996. Soma and Saito 1983). Fungi therefore seem to play an important role in the nutrition of terrestrial isopods (Horváthová et al. 2016, Soma and Saito 1983, Zimmer and Topp 1998). Gut content analyses indeed revealed that fungal tissue makes up a significant proportion of their diet (Soma and Saito 1983), which contributes to biomass gain of isopods (Zimmer et al.|2003). Zimmer et al. (2003) assumed that the presence of microorganisms indicates the presence of high-quality and easily digestible food and that specific microbe-derived chemicals may function as phagostimulants for isopods. Recent studies show an immediate contribution of fungal tissue to the diet of isopods and they have thus been classified as keystone predators of fungi, which impact fungal communities on a global scale (Crowther et al. 2013).

While the bacteria/fungus-mediated food choice involving direct contact with the food source is well investigated, there is only one study showing that isopods - without prior contact with a substrate - were more strongly attracted to the odour of microbe-colonised litter than to the odour of sterile litter (Zimmer et al. 1996). However, as this study does not provide any taxonomic information on the microbial colonisers, it remains unknown whether attraction was mediated by volatiles from bacteria or fungi. For a better understanding of isopods in decomposer community and food web ecology, it is important to reveal the chemical mechanisms underlying the feeding decisions of these keystone foragers. By analysing movement patterns of Oniscus asellus woodlice in response to the fungus C. globosum, the present study aims to provide a first glimpse into the role of fungal volatiles as infochemicals in the foraging behaviour of isopods. 
C. globosum is a common saprotrophic soil fungus that colonises dead plant material and has been shown to be a suitable food source for isopods (Ihnen and Zimmer 2008, Rothe and Gleixner 2000). When grown on a standard microbiology culture medium, the volatile profile of C. globosum is dominated by two major compounds, 3-methyl-1-butanol and 3octanone (Chapter 2, Subsection 2.4.1). 3-methyl-1-butanol is emitted by many bacteria and fungi (Lemfack et al. 2018) and has been suggested to be a reliable indicator of microbial activity (Korpi et al. 2009; 1998). 3-octanone is known to be one of the most common volatiles produced by fungi (Börjesson et al. 1992, Korpi et al. 2009, Schuchardt and Kruse 2009. Schuchardt and Strube 2013). While the abundance of 3-octanone is low in undisturbed C. globosum colonies, tissue wounding causes a significant increase of this compound and additionally triggered the formation of 3-octyl acetate (Chapter 2, Subsection 2.4.1). The precursor of 3-octyl acetate, 3-octanol, as well as 3-octanone belong to the so-called oxylipins and derive from the lipoxygenase (LOX)-pathway (Tressl et al. 1982). Conserved among plants and fungi, the wound-activated increase of oxylipins represents a common response and is of major importance for cross-kingdom communication and driving interactions between fungi, plants, and animals (Brodhun and Feussner 2011). Several studies on plant-insect interactions have shown that volatile oxylipins, especially six-carbon green leaf volatiles, are crucial in regulating the foraging behaviour of herbivorous insects (e.g. Bruce et al. 2005, Schoonhoven et al. 2005, Wei and Kang 2011). In an analogous manner, fungal volatile oxylipins possibly act as infochemicals influencing the foraging patterns of fungusassociated arthropods (Holighaus and Rohlfs 2016; 2018). I was therefore especially interested in the response of isopods to the wide-spread fungal ketone 3-octanone. The present study was designed to answer the following questions: (1) Are components of the O. asellus foraging behaviour - attraction, repulsion, arrestance - influenced by volatiles emitted by C. globosum? (2) If yes, what is the contribution of 3-octanone and 3-methyl-1-butanol? (3) Does the wound-activated release of fungal oxylipins alter isopod responses to C. globosum? With this study I aim to provide first insights into how fungal volatiles and dynamics therein contribute to spatial variation in a keystone predator of fungi. 


\subsection{Material And Methods}

\subsubsection{FIELD COLlECTION OF O. asellus AND CULTIVATION OF C. globosum}

O. asellus individuals were collected in March 2016 (first experiment with fungal colonies) and September 2017 (second experiment with authentic compounds) from deadwood in the Göttinger Forest, central Germany (5132' N, $9^{\circ} 57^{\prime}$ E). Males were identified, transferred to ventilated screw-top jars filled with moist plaster and activated charcoal (40:1), and kept at $20^{\circ} \mathrm{C}$ in constant darkness. Directly after the field collection the animals were starved for eight days prior to the experiments. The plaster was moisturised regularly. To avoid any sex-specific differences in olfaction and subtle variation in female reproductive stage on the foraging behaviour, only males were used.

C. globosum was cultivated on sterile malt extract agar medium (6 g agar, $9 \mathrm{~g}$ malt extract, 1.5 g soy peptone, filled up to $300 \mathrm{ml}$ with $\mathrm{H}_{2} \mathrm{O}$ ) at $20^{\circ} \mathrm{C}$ in constant darkness and maintained by transferring pieces of fungal tissue to fresh medium plates regularly. Fungal colonies for the experiments developed for five days on $3 \mathrm{ml}$ malt extract agar in polypropylene cups (25 $\mathrm{mm}$ in diameter, $7 \mathrm{~mm}$ in height).

\section{TRACKING OF ISOPOD MOVEMENT IN RESPONSE TO FUNGAL COLONIES AND AUTHENTIC COMPOUNDS}

The computer software CyberLink PowerDirector ${ }^{\circledR}$ (CyberLink Corporation, Taipei, Taiwan) and an infrared camera were used for video recording of $O$. asellus movement in a no-choice still-air olfactometer at $20^{\circ} \mathrm{C}$. Circular glass Petri dishes $(19 \mathrm{~cm}$ in diameter), filled with $450 \mathrm{ml}$ water agar to provide a moist and smooth surface, were used to define the experimental arena. To obtain indirect and even illumination of the experimental arena, two infrared lamps (Kema Electronic Co., 12-15 V/DC, M120) were installed below within a polystyrene box and covered with a frosted perspex screen (Chapter 2, Figure 2.2). Immediately prior to the recording, a polypropylene cup, containing the respective volatile source, was placed in the centre of the arena (Figure 3.1). The cup was covered with plastic gauze (mesh $2 \mathrm{~mm}$ ) to prevent isopods from getting into direct contact with the volatile source. Single isopods were released at the edge of the arena and remained trapped in a 
glass vial for a two-minute acclimatisation period before starting the 15-minute recording session. After removal of the glass vial, the arena was covered with a glass plate. Observations were carried out on different days with an equal number of replicates per treatment per day (randomised).

In a first experiment isopod movement patterns were observed in response to unwounded and wounded C. globosum colonies, and malt extract agar (controls) $(n=20)$. Standardised wounding of fungal tissue was done using a thin wire loop; nearly $50 \%$ of the fungal tissue were disrupted by scratching a mesh pattern (four horizontal and four vertical scratches) without injuring the culture medium. In a second experiment, movement patterns of isopods were observed in response to authentic 3-octanone (96\%, CAS: 106-68-3, Merck, Darmstadt, Germany), 3-methyl-1-butanol (98.5\%, CAS: 123-51-3, Merck), and a solvent control $(n=10)$. By means of gas chromatography-mass spectrometry both compounds were found to be emitted by unwounded as well as wounded C. globosum colonies (Chapter 2, Subsection 2.4.1). Whereas headspace concentrations of 3-octanone were significantly increased in wounded colonies, 3-methyl-1-butanol concentrations were not affected by tissue wounding (Chapter 2, Subsection 2.4.1). To mimic 3-octanone concentrations that resemble the ones in the headspace of unwounded and wounded fungi, the compounds were diluted with paraffin (CAS: 8012-95-1, Merck) at concentrations w/w $10^{-6}$ and $10^{-4}$ respectively. Pure paraffin served as solvent control treatment. 3-methyl-1-butanol was tested at concentrations of $\mathrm{w} / \mathrm{w} 10^{-6}$ and $10^{-8}$, the latter resembling to quantities measured in the headspace of both wounded and unwounded C. globosum colonies (Chapter 2, Subsection 2.4.1). A circular piece of absorbent filter paper (15 $\mathrm{mm}$ in diameter) was placed within a polypropylene cup (25 $\mathrm{mm}$ in diameter, $7 \mathrm{~mm}$ in height) and impregnated with $100 \mu \mathrm{l}$ compound solution or pure paraffin. 


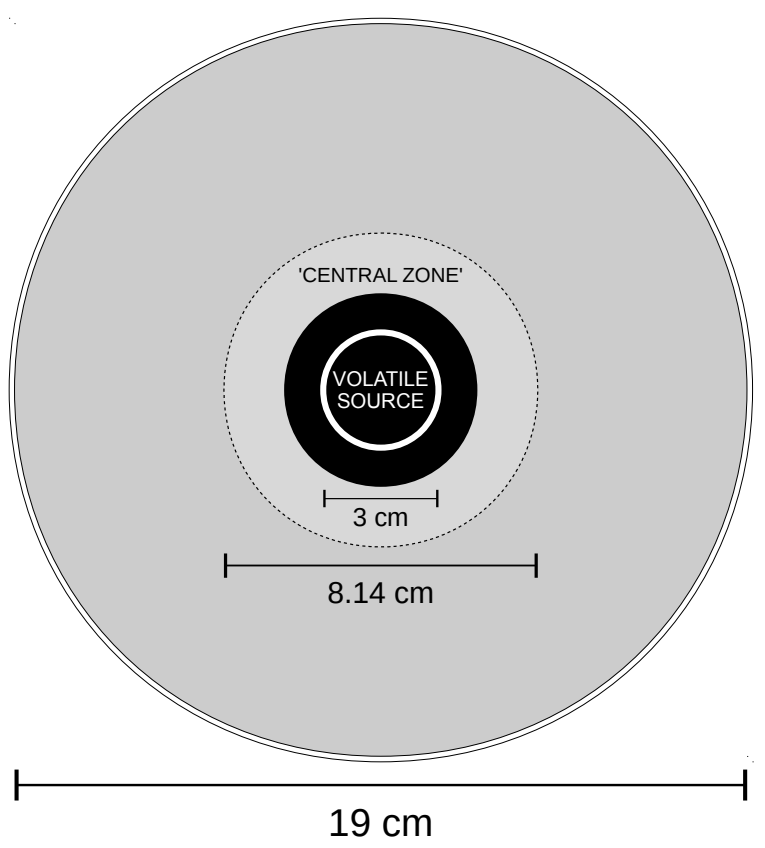

Figure 3.1: Layout and dimensions of the experimental arena with a 'central zone' defined around the volatile source by means of EthoVision ${ }^{\circledR} X T$ (arena settings) for assessing responses of individual $\mathrm{O}$. asellus isopods to $\mathrm{C}$. globosum fungal colonies and authentic compounds 3-octanone and 3-methyl-1-butanol. As the sample vessel (polypropylene pod containing the volatile source) caused background noise and consequently interfered with proper detection of the animal, which leads to disruptions of the automated tracking process in EthoVision ${ }^{\circ} X$, the black area enclosing the volatile source was excluded from the experimental arena.

\section{VIDEO ANALYSIS}

Using the semi-automated tracking platform EthoVision ${ }^{\circledR}$ XT (version 8.0; Noldus Information Technology, Wageningen, Netherlands) (Noldus et al. 2001) isopod movement patterns were assessed by means of spatial measurements in relation to a 'central zone' that was defined around the volatile source (Figure 3.1). Among a number of variables that were captured and calculated by EthoVision ${ }^{\circledR} \mathrm{XT}$, the following were selected to express attraction and/or arrestance of isopods and to quantify and compare the attractivity of the different volatile sources: (1) 'latency to the first arrival at the central zone', (2) 'duration of the first central zone visit', (3) 'percentage of time in the central zone'. If the natural fungal volatiles or the authentic compounds act as attractants, isopods were expected to enter the 'central zone' more rapidly compared to the fungal-free and the paraffin control treatment respectively. If the volatiles have arresting effects, the animals were expected to reside longer in the 'central zone' compared to the control treatments, immediately after they first visited that zone or relative to the overall amount of time. 


\subsubsection{STATISTICS}

Data was analysed using the $\mathrm{R}$ statistical environment (RStudio, version 1.0.153 for Mac OS X, R Development Core Team (2008)). A Cox regression with likelihood estimates was applied on time-dependent event data ('latency to the first arrival at the central zone', 'duration of the first central zone visit') to test whether isopod arrival and departure tendencies differ between treatments. In case of global significance pairwise differences between treatments were tested using Log-Rank tests. Global and per-variable proportionality of hazards was verified by visual examination of Schoenfeld residuals plots and tested by means of goodness-of-fit $\tilde{\chi}^{2}$ tests (function 'cox.zph'). This diagnostic analysis revealed proportionality with respect to the $C$. globosum fungal treatment, thus a regular unweighted Cox regression was applied (function 'coxph', package 'survival'). Regarding the authentic compounds (full model including 3-methyl-1-butanol and 3-octanone at both concentrations, and paraffin controls) proportionality of hazard rates was violated concerning both timedependent variables 'latency to the first arrival' (global $\tilde{\chi}^{2}=9.85, p=0.043$ ) and 'duration of the first central zone visit' (global $\tilde{\chi}^{2}=11.97, p=0.018$ ), i.e. the average hazard ratio for the respective factor is under- or overestimated. Therefore, a weighted Cox regression with different weight per event (function, package 'coxphw', template='AHR') was applied to estimate average hazard ratios as proposed by Schemper et al. (2009).

The effect of volatile sources on isopods' 'percentage of time in the central zone' (percentage of total observation time) was tested with a beta regression model (function 'betareg', package 'betareg'). The data was transformed using a method proposed by Smithson and Verkuilen (2006) (formula: $\left.\left.y *\left(n_{o b s-1}\right)+0.5\right) / n_{o b s}\right)$ ) to eliminate zeros and allow for applying a beta regression. For testing the effect of the volatile treatment with respect to fungal colonies (unwounded, wounded) and the medium control, the volatile treatment (explanatory variable) entered the model as categorical variable. An analysis of variance (function 'Anova', package 'car') was applied to test for global significance of the volatile treatment effect. To test for a significant difference between unwounded and wounded colonies Tukey's post-hoc test (function 'glht', package 'multcomp') was used. The effects of the authentic compounds 3-octanone ( $\mathrm{w} / \mathrm{w} 10^{-4}$ and $10^{-6}$ ) and 3-methyl-1-butanol $\left(\mathrm{w} / \mathrm{w} 10^{-6}\right.$ and $\left.10^{-8}\right)$ on the 'percentage of time in the central zone' were analysed independently and the compound concentration (explanatory variable) entered the model as continuous variable. An analysis of variance (function 'Anova', package 'car') was applied to test for a global significant treatment effect. 


\subsection{RESUlTS}

\subsubsection{ISOPOD MOVEMENT PATTERNS IN RESPONSE TO UNWOUNDED AND WOUNDED C. globosum COLONIES}

In the light of the striking wound-activated changes in the volatile profile of C. globosum, it was tested whether isopods alter the spatial foraging behaviour in response to unwounded and wounded C. globosum colonies. The arrival tendency of isopods at the 'central zones' (variable: 'latency to first arrival') was significantly affected by the presence of C. globosum (Cox regression, likelihood ratio test, $\left.\tilde{\chi}^{2}=8.32, \mathrm{df}=2, p=0.016\right)$. Hazard ratios (exp(coef)) indicate that the arrival tendency of isopods in the presence of an unwounded C. globosum colony was 2.2 times higher $(p=0.024)$ and in the presence of a wounded colony 2.44 times higher $(p=0.010$ ) compared to the tendency to arrive at fungal-free controls (Figure 3.2a). Whereas 16 out of 20 animals arrived in the presence of controls, 19 and 20 animals arrived in the presence of unwounded and wounded C. globosum colonies respectively. However, the 'duration of the first central zone visit' was not different between treatments (Cox regression, likelihood ratio test, $\tilde{\chi}^{2}=2.83, \mathrm{df}=2, p=0.242$ ). A significant effect was also observed with respect to the 'percentage of time in the central zone' (Beta regression, ANOVA Type II, $\left.\tilde{\chi}^{2}=13.92, \mathrm{df}=2, p<0.001\right)$. Compared to the 'percentage of time in the central zone' of fungalfree controls isopods spent a significantly higher percentage of the time in 'central zones' of wounded colonies (Beta regression, $\mathrm{z}=2.71, \mathrm{df}=2, p=0.007$ ) (Figure 3.2b), however, no significant difference was found between the control and unwounded colonies (Beta regression, $\mathrm{z}=1.88, \mathrm{df}=2, p=0.060$ ). A pairwise comparison between unwounded and wounded treatment groups with regard to both 'latency to the first arrival' (Post-hoc test Log-Rank test, $\mathrm{df}=2, p=0.701$ ) and 'percentage of time in the central zone' (Post-hoc test Tukey, $\mathrm{t}=-0.85, \mathrm{df}=2$, $p=0.485$ ) revealed that fungal tissue wounding did not affect isopod movement patterns. 
(a)

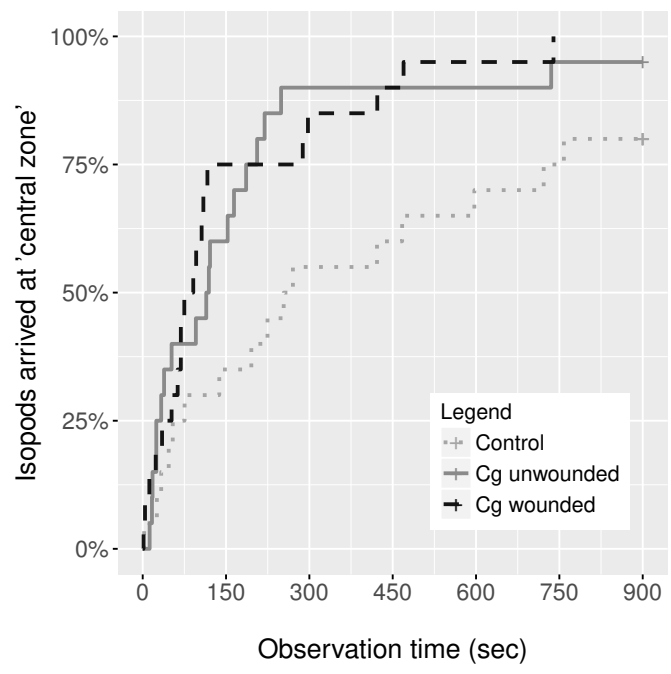

(b)

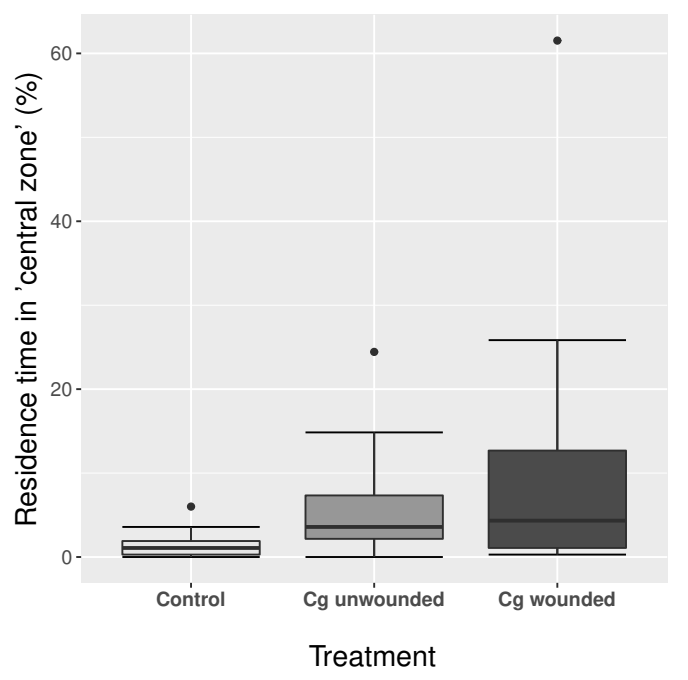

Figure 3.2: Response of isopods to fungal colonies. (a) Arrival tendencies (variable: 'latency to the first arrival at the central zone') and (b) 'percentage of time in central zones' (\% of total observation time) of O. asellus in the presence of unwounded and wounded C. globosum colonies and fungal-free controls (observation period: 15 minutes).

\subsubsection{ISOPOD MOVEMENT PATTERNS IN RESPONSE TO AUTHENTIC COMPOUNDS 3-OCTANONE AND 3-METHYL-1-BUTANOL}

O. asellus responses to authentic compounds 3-octanone and 3-methyl-1-butanol were observed to identify those volatile compounds that are causative for previously observed differences in O. asellus responses between C. globosum colonies and fungal-free controls. A significant global treatment effect was found with respect to the 'latency to the first arrival at the central zone' (arrival tendency) (Cox regression, likelihood ratio test, $\tilde{\chi}^{2}=12.18$, $\mathrm{df}=4, p=0.016)$. Interestingly, comparisons of compound treatments against the solvent control revealed that the tendency of isopods to arrive at the 'central zone' was significantly $(63 \%)$ lower in the presence of the higher concentration of 3-methyl-1-butanol (Table 3.1) (Figure 3.3a). Arrival tendencies in the presence of 3-octanone and the lower concentration of 3-methyl-1-butanol $\left(10^{-8}\right)$, however, did not differ from the control. The 'duration of the first central zone visit' (departure tendency) was not affected by the volatile treatment (Cox regression, likelihood ratio test, $\left.\tilde{\chi}^{2}=7.91, \mathrm{df}=4, p=0.095\right)$. The overall proportion of time spent in the central zone increased with increasing 3-octanone concentration (Beta regression, ANOVA Type II, $\tilde{\chi}^{2}=4.24, \mathrm{df}=1, p=0.039$ ), yet this time remained unaltered in the 
presence of different 3-methyl-1-butanol concentrations (Beta regression, ANOVA Type II, $\tilde{\chi}^{2}=0.17, \mathrm{df}=1, p=0.681$ ) Figure 3.3b). The 'duration of the first central zone visit' (departure tendency) was not affected by the volatile treatment (Cox regression, likelihood ratio test, $\left.\tilde{\chi}^{2}=7.91, \mathrm{df}=4, p=0.095\right)$.

Table 3.1: Cox regression pairwise comparisons of 3-octanone and 3-methyl-1-butanol treatment groups against the control group with respect to the 'latency to the first arrival at the central zone' (arrival tendency). Effect size is represented by the hazard ratio $(\exp (c o e f))$.

\begin{tabular}{|c|c|c|c|c|c|}
\hline Comparison & $N$ & Events & $Z$ & $\exp (\text { coe } f)^{(*)}$ & $P-$ value \\
\hline Control - 3-octanone $10^{-4}$ & 20 & 19 & 0.29 & 1.17 & 0.768 \\
\hline Control - 3-octanone $10^{-6}$ & 20 & 19 & -0.90 & 0.67 & 0.367 \\
\hline Control - 3-methyl-1-butanol 10-6 & 20 & 18 & -2.52 & 0.37 & 0.012 \\
\hline Control - 3-methyl-1-butanol 10-8 & 20 & 17 & 0.27 & 1.18 & 0.784 \\
\hline
\end{tabular}

(*) Given hazard ratios relate to the respective authentic compound treatment group. A value lower than 1 indicates a decreased tendency of isopods to arrive at the 'central zone'.

(a)

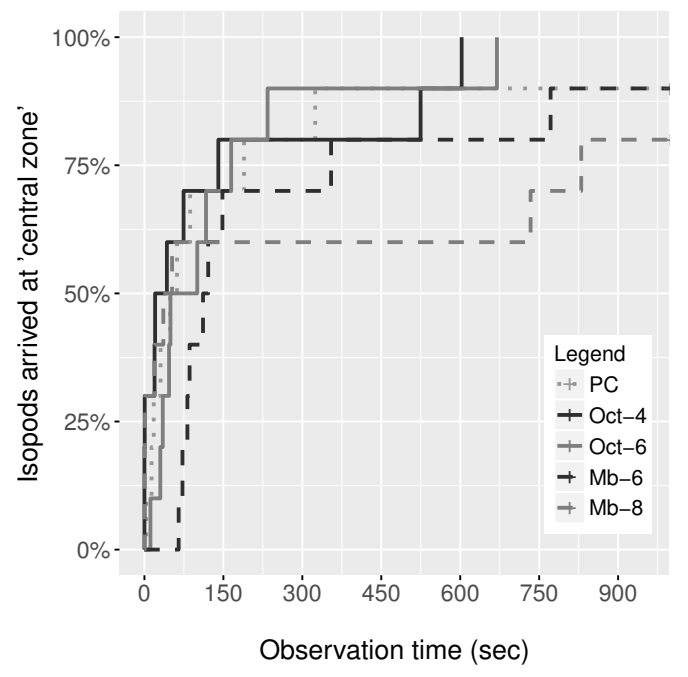

(b)

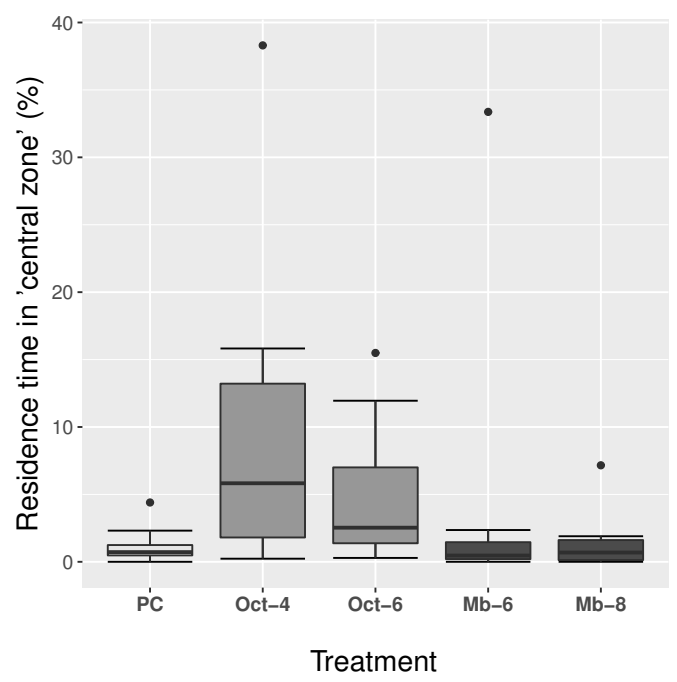

Figure 3.3: O. asellus (a) arrival tendencies (variable: 'latency to the first arrival at the central zone') and (b) 'percentage of time in the central zone' (\% of total observation time) in response to 3-octanone in concentrations of $\mathrm{W} / \mathrm{w} 10^{-6}(\mathrm{Oct}-6)$ and $10^{-4}\left(\right.$ Oct-4), 3-methyl-1-butanol in concentrations of $\mathrm{w} / \mathrm{W} 10^{-8}(\mathrm{Mb}-8)$ and $10^{-6}(\mathrm{Mb}-6)$, and paraffin controls $(P C)$ within an observation period of 15 minutes. 


\subsection{Discussion}

Previous studies have suggested that food location by O. asellus isopods requires physical contact with the food source (Gunnarsson 1987, Zidar et al. 2003). The results of the present study provide first evidence of a role of fungal-borne volatiles in establishing contact between $O$. asellus and a dietary saprotrophic fungus. A higher 'arrival tendency' and 'percentage of time in the central zone' in the presence of C. globosum colonies indicate that isopods are attracted, and in addition, arrested in close proximity to fungal colonies. This supports the hypothesis that isopods use fungal volatiles as information to locate food from a distance and agrees with Zimmer et al. (1996), who reported that Porcellio scaber isopods are attracted to volatiles deriving from litter-colonising microorganisms rather than volatiles of the litter itself. Thus, the use of microbial/fungal volatiles is supposed to be a mechanism in terrestrial isopod foraging to locate favourable microhabitats characterised by high microbial activity.

Since wounding of fungal tissue activates volatile oxylipin emissions, it was hypothesised that isopods locate microhabitats with high microbial and detritivore activity more easily and, therefore, are more strongly attracted to wounded C. globosum colonies than to unwounded colonies. Unexpectedly, isopods were attracted to and arrested by unwounded and wounded C. globosum colonies to the same extent. In line with this, responses of isopods to the authentic compound 3-octanone indicate that this oxylipin compound did not elicit attraction. The higher percentage of time spent in close proximity to the 3-octanone source, however, indicates that isopods were arrested by this compound. The second C. globosum authentic compound that was tested for attracting isopods, 3-methyl-1-butanol, is known to derive from dead plant material that is colonised by microorganisms (Bjurman)1997, Isidorov and Jdanova 2002, Wheatley et al. 1996) and was repeatedly found to mediate attraction in fungus-arthropod interactions (Becher et al.|2012, Lin and Phelan|1991, Phelan and Lin|1991, Rizvi and Raman|2016, Stötefeld et al.|2015, Tasin et al.|2012). However, the results show that this compound did not attract $O$. asellus isopods; on the contrary, a concentration of $\mathrm{w} / \mathrm{w}$ $10^{-6}$ of 3-methyl-1-butanol apparently had a deterrent effect. The results indicate that both volatile compounds, 3-octanone and 3-methyl-1-butanol, affect the foraging behaviour of isopods, but isopod responses to individual compounds do not explain the observed attraction of isopods to C. globosum colonies. The fact that isopods were attracted to C. globosum but not to the main compounds produced by this dietary fungus is surprising. Two possible explanations for these contradictory results are conceivable: (1) synergistic interactions 
of volatile compounds elicited attraction to C. globosum; (2) other C. globosum-derived compounds, not tested in the present study, attracted isopods. Possible candidate volatiles that come into question to be responsible for isopod attraction to C. globosum colonies are highly volatile compounds, e.g. carbon dioxide or short-chain alcohols. GC-MS analysis revealed the presence of carbon dioxide and ethanol in headspace samples of both fungal-free malt extract agar controls and C. globosum colonies (Chapter 2, Subsection 2.4.1). Quantities of respective compounds and differences between control and fungal samples, however, could not be determined due to overlap and interference of the compound peaks. Therefore, one can only speculate that these compounds were responsible for or at least contributed to isopod attraction. In the light of the findings that the number of isopods captured in the field is positively correlated with cellulytic and respiratory activity of microorganisms (Zimmer and Topp 1999) and that fungi facilitate the exploitation of cellulose rich plant detritus and thus benefit individual isopod fitness (Uesbeck and Topp 1995, Zimmer and Topp 1997), it is likely that isopods are attracted to volatiles that relate to microbial respiration (Öhlinger et al.1996), indicating microbial activity and the presence of suitable food sources.

The significance of fungal volatiles in mediating fungus-arthropod interactions similar to that of isopods and fungi, viz. interactions in which fungi act as niche constructors by paving the way for invertebrate colonisers via modification of plant material, was demonstrated with regard to Coleoptera (Belmain et al. 2002, Blackmer and Phelan|1991. Hulcr et al. 2011. Lin and Phelan|1991, Nout and Bartelt|1998, Phelan and Lin|1991), Diptera (Becher et al. 2012, Buser et al.|2014, Dobzhansky et al.|1956, Fischer et al.|2017, Palanca et al.|2013, Stötefeld et al. 2015), and Lepidoptera (Mondy et al. 1998, Rizvi and Raman|2016, Tasin et al. 2011: 2012, Witzgall et al. 2012). Volatile compounds that were repeatedly found to mediate attraction in respective systems are mainly alcohols, aldehydes, and acetates (Becher et al. 2012, Lin and Phelan 1991, Nout and Bartelt 1998, Phelan and Lin 1991, Rizvi and Raman 2016, Stötefeld et al. 2015, Tasin et al. 2012) - common compounds that are known to be produced by a wide range of fungi and other microorganisms. These studies suggest that arthropods associated with microbe-infected plant material use common ubiquitous fungal/microbial volatiles to detect and locate preferred feeding and/or oviposition sites. The present study provides first evidence that isopods also use fungal volatile cues during foraging, but further work is needed to identify those volatiles and possible synergistic effects that mediate the here observed attraction response.

In conclusion this study clearly shows that fungal volatiles influence the spatial foraging behaviour of isopods and are used as infochemicals to locate food from a distance. Whereas ar- 
restance of isopods in the presence of $C$. globosum can be attributed to the authentic oxylipin volatile 3-octanone, attraction to fungal colonies could not be explained by the single compound effects. Contrary to expectations, wounding of fungal tissue and related activation/increase in oxylipin emissions did not further increase the attractivity of fungal colonies. Further research is needed to explain the here observed behavioural responses and to fully understand the role of fungal volatiles in mediating isopod-fungus interactions. Future experiments need to aim at the identification of those fungal authentic compounds responsible for isopod attraction, particularly by investigating isopod responses to further common fungal volatiles and with regard to possible synergistic effects. 


\section{REFERENCES}

Abd El-Wakeil KF, 2015. Effects of terrestrial isopods (Crustacea: Oniscidea) on leaf litter decomposition processes. The Journal of Basic E Applied Zoology, 69:10-16. ISSN 20909896. doi:10.1016/j.jobaz.2015.05.002.

Becher PG, Flick G, Rozpȩdowska E, Schmidt A, Hagman A, Lebreton S, Larsson MC, Hansson BS, Piškur J, Witzgall P, and Bengtsson M, 2012. Yeast, not fruit volatiles mediate Drosophila melanogaster attraction, oviposition and development. Functional Ecology, 26(4):822-828. ISSN 02698463. doi:10.1111/j.1365-2435.2012.02006.x.

Belmain SR, Simmonds MSJ, and Blaney WM, 2002. Influence of odor from wood-decaying fungi on host selection behavior of deathwatch beetle, Xestobium rufovillosum. Journal of Chemical Ecology, 28(4):741-754. ISSN 00980331. doi:10.1023/A:1015284625697.

Bjurman J, 1997. Growth-phase-related production of potential volatile organic tracer compounds by moulds on wood. Indoor Air, 7(1):2-7. ISSN 09056947. doi:10.1111/j.1600-0668. 1997.t01-3-00002.x.

Blackmer JL and Phelan PL, 1991. Effect of physiological state and fungal inoculation on chemically modulated host-plant finding by Carpophilus hemipterus and Carpophilus lugubris. Entomologia Experimentalis et Applicata, 61(1):33-43. ISSN 15707458. doi: 10.1111/j.1570-7458.1991.tb02393.x.

Börjesson T, Stollman U, and Schnurer J, 1992. Volatile metabolites produced by 6 fungal species compared with other indicators of fungal growth on cereal-grains. Applied and Environmental Microbiology, 58(8):2599-2605.

Brodhun F and Feussner I, 2011. Oxylipins in fungi. FEBS Journal, 278(7):1047-1063. ISSN 1742464X. doi:10.1111/j.1742-4658.2011.08027.x.

Bruce TJA, Wadhams LJ, and Woodcock CM, 2005. Insect host location: a volatile situation. Trends in Plant Science, 10(6):269-274. ISSN 13601385. doi:10.1016/j.tplants.2005.04.003.

Buser CC, Newcomb RD, Gaskett AC, and Goddard MR, 2014. Niche construction initiates the evolution of mutualistic interactions. Ecology Letters, 17(10):1257-1264. ISSN 14610248. doi:10.1111/ele.12331.

Carefoot TH, 1993. Physiology of terrestrial isopods. Comperative Biochemical Physiology, 106(3):413-429. doi:10.1016/0300-9629(93)90235-v.

Crowther TW, Stanton DWG, Thomas SM, A'Bear AD, Hiscox J, Jones TH, Vorísková J, Baldrian P, and Boddy L, 2013. Top-down control of soil fungal community composition by a globally distributed keystone consumer. Ecology, 94(11):2518-2528. doi: 10.1890/13-0197.1.

Dobzhansky T, Cooper DM, Phaff HJ, Knapp EP, and Carson HL, 1956. Differential attraction of species of Drosophila to different species of yeasts. Ecology, 37(3):544-550. doi: $10.2307 / 1930178$. 
Fischer C, Trautman EP, Crawford JM, Stabb EV, Handelsman J, and Broderick NA, 2017. Metabolite exchange between microbiome members produces compounds that influence Drosophila behavior. eLife, 6:1-25. ISSN 2050-084X. doi:10.7554/eLife.18855.

Gunnarsson T, 1987. Selective feeding on a maple leaf by Oniscus asellus (Isopoda). Pedobiologia, 30:161-165.

Hassall M and Rushton S, 1984. Feeding behaviour of terrestrial isopods in relation to plant defenses and microbial activity. Symposium of the Zoological Society of London, 53:487 - 505.

Hassall M, Turner JG, and Rands MR, 1987. Effects of terrestrial isopods on the decomposition of woodland leaf litter. Oecologia, 72(4):597-604. ISSN 00298549. doi: 10.1007/BF00378988.

Holighaus G and Rohlfs M, 2016. Fungal allelochemicals in insect pest management. Applied Microbiology and Biotechnology, 100(13):5681-5689. ISSN 14320614. doi:10.1007/ s00253-016-7573-x.

Holighaus G and Rohlfs M, 2018. Volatile and non-volatile fungal oxylipins in fungus invertebrate interactions. Fungal Ecology (in press). doi:10.1016/j.funeco.2018.09.005.

Horváthová T, Babik W, and Bauchinger U, 2016. Biofilm feeding: microbial colonization of food promotes the growth of a detritivorous arthropod. ZooKeys, 2016(577):25-41. ISSN 13132970. doi:10.3897/zookeys.577.6149.

Hulcr J, Mann R, and Stelinski LL, 2011. The scent of a partner: ambrosia beetles are attracted to volatiles from their fungal symbionts. Journal of Chemical Ecology, 37(12):1374-1377. ISSN 00980331. doi:10.1007/s10886-011-0046-x.

Ihnen $\mathrm{K}$ and Zimmer M, 2008. Selective consumption and digestion of litter microbes by Porcellio scaber (Isopoda: Oniscidea). Pedobiologia, 51(5-6):335-342. ISSN 00314056. doi: 10.1016/j.pedobi.2007.06.001.

Isidorov V and Jdanova M, 2002. Volatile organic compounds from leaves litter. Chemosphere, 48(9):975-9. ISSN 0045-6535. doi:10.1016/S0045-6535(02)00074-7.

Kayang DDH, Sharma GD, and Mishra RR, 1996. The influence of isopod grazing on microbial dynamics in decomposing leaf litter of Alnus nepalensis. European Journal of Soil Biology, 32(1):35-39. ISSN 11645563.

Korpi A, Jarnberg J, and Pasanen AL, 2009. Microbial volatile organic compounds. Critical Reviews in Toxicology, 39(2):139-193. ISSN 1040-8444. doi:10.1080/10408440802291497.

Lemfack M, Gohlke B, Toguem SMT, Preissner S, Piechulla B, and Preissner R, 2018. mVOC 2.0: a database of microbial volatiles. Nucleic Acids Research, 46(D1):D1261-D1265. doi: 10.1093/nar/gkx1016.

Lin H and Phelan PL, 1991. Identification of food volatiles attractive to dusky sap beetle, Capophilus lugubris (Coleoptera: Nitidulidae). Journal of Chemical Ecology, 17(6):1273-1286. doi:10.1007/BF01402949.

Mondy N, Pracros P, Fermaud M, and Corio-Costet MF, 1998. Olfactory and gustatory behaviour by larvae of Lobesia botrana in response to Botrytis cinerea. Entomologia Experimentalis et Applicata, 88(1):1-7. ISSN 00138703. doi:10.1023/A:1003286931364. 
Noldus LPJJ, Spink AJ, and Tegelenbosch RAJ, 2001. EthoVision: a versatile video tracking system for automation of behavioral experiments. Behavior Research Methods, Instruments, $\mathcal{E}$ Computers, 33(3):398-414. ISSN 0743-3808. doi:10.3758/BF03195394.

Nout MJR and Bartelt RJ, 1998. Attraction of a flying nitidulid (Carpophilus humeralis) to volatiles produced by yeasts grown on sweet corn and a corn-based medium. Journal of Chemical Ecology, 24(7):1217-1239. doi:10.1023/A:1022451020013.

Öhlinger R, Beck T, Heilmann B, and Beese F, 1996. Soil respiration. In F Schinner, R Öhlinger, E Kandeler, and R Margesin, editors, Methods in soil biology, pages 93-110. Springer Berlin Heidelberg.

Palanca L, Gaskett AC, Günther CS, Newcomb RD, and Goddard MR, 2013. Quantifying variation in the ability of yeasts to attract Drosophila melanogaster. PLoS ONE, 8(9):1-10. doi:10.1371/journal.pone.0075332.

Phelan PL and Lin H, 1991. Chemical characterization of fruit and fungal volatiles attractive to dried-fruit beetle, Carpophilus hemipterus (L.) (Coleoptera: Nitidulidae). Journal of Chemical Ecology, 17(6):1253-1272. doi:10.1007/BF01402948.

R Development Core Team, 2008. R: a language and environment for statistical computing. www.r-project.org. ISBN 3-900051-07-0.

Rizvi SZM and Raman A, 2016. Volatiles from Botrytis cinerea-infected and healthy berries of Vitis vinifera influence the oviposition behaviour of Epiphyas postvittana. Entomologia Experimentalis et Applicata, 160(1):47-56. ISSN 15707458. doi:10.1111/eea.12461.

Rothe J and Gleixner G, 2000. Do stable isotopes reflect the food web development in regenerating ecosystems? Isotopes in Environmental and Health Studies, 36(3):285-301. ISSN 10256016. doi:10.1080/10256010008036388.

Schemper M, Wakounig S, and Heinze G, 2009. The estimation of average hazard ratios by weighted Cox regression. Statistics in Medicine, 28:2473-2489. doi:10.1002/sim.3623.

Schoonhoven LM, van Loon JJA, and Dicke M, 2005. Insect-plant biology. Oxford University Press, New York, 2 edition. ISBN 978-0-19-852594-3.

Schuchardt S and Kruse H, 2009. Quantitative volatile metabolite profiling of common indoor fungi: relevancy for indoor air analysis. Journal of Basic Microbiology, 49(4):350-362. ISSN 0233111X. doi:10.1002/jobm.200800152.

Schuchardt S and Strube A, 2013. Microbial volatile organic compounds in moldy interiors: a long-term climate chamber study. Journal of Basic Microbiology, 53(6):532-538. ISSN 0233111X. doi:10.1002/jobm.201200056.

Smithson M and Verkuilen J, 2006. A better lemon squeezer? Maximum-likelihood regression with beta-distributed dependent variables. Psychological Methods, 11(1):54-71. ISSN 1082989X. doi:10.1037/1082-989X.11.1.54.

Soma K and Saito T, 1983. Ecological studies of soil organisms with references to the decomposition of pine needles. II. Litter feeding and breakdown by the woodlouse, Porcellio scaber. Plant and Soil, 75(1):139-151. doi:10.1007/bf02178621. 
Stöckli H, 1990. Das Unterscheidungsvermögen von Porcellio scaber (Crustacea, Isopoda) zwischen Blättern einer Baumart, unter Berücksichtigung der makroskopisch sichtbaren Verpilzung. Pedobiologia, 34:191-205.

Stötefeld L, Holighaus G, Schütz S, and Rohlfs M, 2015. Volatile-mediated location of mutualist host and toxic non-host microfungi by Drosophila larvae. Chemoecology, 25(5):271-283. ISSN 09377409. doi:10.1007/s00049-015-0197-2.

Tasin M, Betta E, Carlin S, Gasperi F, Mattivi F, and Pertot I, 2011. Volatiles that encode hostplant quality in the grapevine moth. Phytochemistry, 72(16):1999-2005. ISSN 00319422. doi:10.1016/j.phytochem.2011.06.006.

Tasin M, Knudsen GK, and Pertot I, 2012. Smelling a diseased host: grapevine moth responses to healthy and fungus-infected grapes. Animal Behaviour, 83(2):555-562. ISSN 00033472. doi:10.1016/j.anbehav.2011.12.003.

Tressl R, Bahri D, and Engel Kh, 1982. Formation of eight-carbon and ten-carbon components in mushrooms. Journal of Agricultural and Food Chemistry, 3:89-93. doi:10.1021/ jf00109a019.

Uesbeck M and Topp W, 1995. The effect of leaf litter, microorganisms and Collembola on the food allocation of Oniscus asellus. In M Alikhan, editor, Crustacean issues - 9: Terrestrial isopod biology, pages 121-132. CRC Press, Balkema, Rotterdam.

Warburg M, 1987. Isopods and their terrestrial environment. Advances in Ecological Research, 17:187-242. doi:10.1016/S0065-2504(08)60246-9.

Wei J and Kang L, 2011. Roles of (Z)-3-hexenol in plant-insect interactions. Plant Signaling and Behavior, 6(3):369-371. ISSN 15592316. doi:10.4161/psb.6.3.14452.

Wheatley RE, Millar SE, and Griffiths DW, 1996. The production of volatile organic compounds during nitrogen transformations in soils. Plant and Soil, 181(1):163-167. ISSN 0032-079X. doi:10.1007/BF00011303.

Witzgall P, Proffit M, Rozpedowska E, Becher PG, Andreadis S, Coracini M, Lindblom TUT, Ream LJ, Hagman A, Bengtsson M, Kurtzman CP, Piskur J, and Knight A, 2012. "This is not an apple"-yeast mutualism in codling moth. Journal of Chemical Ecology, 38(8):949-957. ISSN 00980331. doi:10.1007/s10886-012-0158-y.

Zidar P, Kaschl U, Drobne D, Bozic J, and Strus J, 2003. Behavioural responses in paired food choice experiments with Oniscus asellus (Crustacea, Isopoda) as an indicator of different food quality. Arhiv Za Higijenu Rada I Toksikologiju, 54:177-181.

Zimmer M, Kautz G, and Topp W, 1996. Olfaction in terrestrial isopods (Crustacea: Oniscidea): responses of Porcellio scaber to the odour of litter. European Journal of Soil Biology, 32(3):141-147.

Zimmer M, Kautz G, and Topp W, 2003. Leaf litter-colonizing microbiota: supplementary food source or indicator of food quality for Porcellio scaber (Isopoda: Oniscidea)? European Journal of Soil Biology, 39(4):209-216. ISSN 11645563. doi:10.1016/j.ejsobi.2003.07.001.

Zimmer M and Topp W, 1997. Does leaf litter quality influence population parameters of the common woodlouse, Porcellio scaber Latr., 1804 (Crustacea: Isopoda). Biology and Fertility of Soils, 24:435-441. ISSN 01782762. doi:10.1007/s003740050269. 
Zimmer M and Topp W, 1998. Microorganisms and cellulose digestion in the gut of the woodlouse Porcellio scaber. Journal of Chemical Ecology, 24(8):1397-1408. ISSN 0098-0331. doi:10.1023/A:1021235001949.

Zimmer M and Topp W, 1999. Relationships between woodlice (Isopoda: Oniscidea) and microbial density and activity in the field. Biology and Fertility of Soils, 30(1-2):117-123. ISSN 01782762. doi:10.1007/s003740050597. 


\section{Снартек 4}

\section{VOLATILE-MEDIATED FORAGING RESPONSES TO YEASTS AND FILAMENTOUS FUNGI CORRELATE WITH FUNGIVORE GROWTH AND REPRODUCTION}

\subsection{Abstract}

Existing research provides evidence for a significant role of fungal volatiles as cues in affecting the foraging behaviour of soil-living fungivorous arthropods by acting as attractants, deterrents, and/or arrestants. Here I tested the hypothesis that hemiedaphic Collembola (F. candida) respond differently to differences in fungal volatile emissions to discriminate between fungi of varying suitability by analysing volatile profiles of different yeast (Cryptococcus terricola, Trichosporon dulcitum, Metschnikowia pulcherrima) and filamentous fungi (Aspergillus nidulans, Penicillium expansum, Trichoderma harzianum) (GC-MS), observing behavioural responses of single Collembola during both the searching and the contact phase of food selection by means of the computer software packages EthoVision ${ }^{\circledR} \mathrm{XT}$ and Observer ${ }^{\circledR}$ XT (Noldus), and evaluating fitness consequences (growth, reproduction) of the respective fungal diets.

Volatile-mediated responses and most notably feeding decisions (acceptance or rejection of fungal food sources) were largely reflected in Collembola fitness measures. In detail, the volatile bouquets of the yeasts, which were composed of only a small number of alcohols and acetates, mediated attraction or arrestance, were accepted as food source and positively affected Collembola growth and reproduction (number of eggs). In case of the filamentous fungi $A$. nidulans and T. harzianum behavioural responses were hardly reflected in Collembola fitness measures. The volatile bouquets of both fungi did not elicit any response. T. harzianum was initially rejected as food source, however, when given as single diet over several days, Collembola increased growth and laid eggs. In contrast, the filamentous fungus $P$. expansum was rejected when direct contact was possible and the results of the fitness assay indicate that this fungus is unsuitable as food source for F. candida. In line 
with this, the volatile bouquet of $P$. expansum, which was found to be characterised by the presence of several terpenoid compounds, deterred the animals. One particular compound, namely geosmin, which is known to elicit avoidance in adult fruit flies, was tested on affecting Collembola movement patterns and found to be responsible for the deterrent effect, at least to some extent. In agreement with the assumption that fungi have evolved chemical defence strategies against antagonists, I suggest that the emission of deterrent volatiles represents an effective chemical defence mechanism against fungivory.

I conclude that the use of fungal volatiles as cues is important for Collembola to increase their fitness. F. candida exhibits food-specific foraging strategies, strongly depending on fungal chemical properties and presumably also on fungal growth characteristics. Unicellular yeasts may be better accessible as food source than filamentous fungi. Whether morphological properties of the here tested fungi play a role in affecting their acceptance as food source remains to be tested.

Keywords: Collembola, fungus-arthropod interaction, foraging behaviour, food selection, fitness, yeasts, filamentous fungi, volatile organic compounds, wounding, oxylipins, geosmin

\subsection{INTRODUCTION}

As main decomposers and colonizers of litter, fungi make up the major part of the total soil microbial biomass (Kjoller and Struwe 1982, Schnürer et al. 1985) and constitute an abundant food source for soil invertebrate decomposers and fungal grazers, including isopods (Crowther et al. 2013), beetles (Harrington 2005), millipedes, springtails, acarids, nematodes, annelids, and gastropods (Maraun et al. 2003) (Chapter 1). Terrestrial soil ecosystems harbour more than 3300 species of filamentous fungi (Gams 2007) and up to 130 yeast species (Esteve-Zarzoso et al.1999). Differences in chemical properties between fungi, viz. the presence of toxic and/or deterrent secondary metabolites, influence foraging and food selection by fungivorous arthropods and may contribute to the occurrence of selective fungal grazing and preferences for certain fungi (Böllmann et al. 2010, , Döll et al. 2013, Rohlfs and Churchill 2011, Stötefeld et al. 2012). There is growing evidence that fungal-derived volatile compounds influence the foraging behaviour of fungivorous soil-living arthropods by acting as attractants, arrestants, repellents, and/or stimulants (Davis et al.|2013, Holighaus and 
Rohlfs 2018). Using a Collembola-fungus model system I aim to investigate the role of fungal volatiles in affecting foraging decisions and success of fungivorous soil arthropods in further detail by analysing fungal volatile profiles, behavioural responses of Collembola during both the searching and the contact phase of food selection (Schoonhoven et al.|2005), and consequences of different fungal diets for Collembola growth and reproduction.

Collembola, a major group of secondary decomposers, are often considered as generalist feeders (Hopkin 1997, Scheu and Setälä 2002). However, several studies attribute a significant role to fungi in the nutrition/diet of Collembola (e.g. Hopkin 1997, Moore et al. 1987, Ponge 1991, Rusek 1998). The existence of different dietary preferences among Collembola species for different fungi even indicates a certain degree of specialisation (Bardgett et al. 1993, Heděnec et al. 2013, Klironomos et al. 2008, Larsen et al. 2008, Men'ko et al. 2006). In many instances grazing preferences were found to be reflected in Collembola fitness measures (e.g. Jørgensen et al. 2008, Klironomos et al. 2008, Men'ko et al. 2006, Rotheray et al. 2009); however, there is only one study that related fitness consequences of different fungal diets to volatile-mediated foraging decisions. Sadaka-Laulan et al. (1998) have shown that Collembola (Onichiurus sinensis) preferences for/avoidance of odour solutions of certain filamentous fungi largely correlate with their feeding decisions and fitness (growth, survival, resproduction) and provide first indication that Collembola are able to detect less suitable fungi by means of volatiles. The relevance of fungal volatiles in affecting Collembola foraging has also been demonstrated by Bengtsson et al. (1988; 1991; 1994), Hedlund et al. (1995), and Staaden et al. (2011). To test the hypothesis that Collembola are able to use fungalderived volatiles as cues to differentiate between fungal food sources of varying suitability from a distance, I use two different groups of fungi, yeasts and filamentous fungi.

Although yeasts have frequently been shown to be engaged in mutualistic interactions with invertebrates (Blackwell|2017), to be a suitable food source for different fungivorous invertebrates - Collembola (Men'ko et al.|2006), Diptera (Anagnostou et al. 2010), Lepidoptera (Witzgall et al. 2012), Coleoptera (Davis 2015), Annelida (Yurkov et al. 2008), Diplopoda (Byzov et al. 1993), and Isopoda (Zimmer 2002) - and to be essential for the acceptance of leaf litter as food source by Collembola (Men'ko et al. 2006), the present study for the first time investigates the role of yeast-derived volatiles in modulating the foraging behaviour of Collembola. Filamentous fungi and unicellular growing yeasts differ in their chemical properties that may determine their suitability as food source. The production of detrimental volatile and non-volatile secondary metabolites, which is characteristic for a range of filamentous fungi, including those species tested in the present study, reduces their suitability as food 
source and is assumed to function as chemical defence against fungivory (Caballero Ortiz et al.|2013, Döll et al.|2013, Holighaus and Rohlfs 2018, Rohlfs 2015, Rohlfs et al.|2007, Spiteller 2008, Stötefeld et al. 2012). In contrast to yeast volatile profiles that often comprise alcohols, acids, esters, and ketones, many species of filamentous fungi additionally produce a range of terpenes and compose volatile profiles that are more characteristic and diverse. Many terpenes are known to function as infochemicals (Gershenzon and Dudareva 2007); for example the terpenoid geosmin, which is produced by the here tested fungus P. expansum, has been shown to reduce the attractiveness of vinegar to fruit flies (Becher et al. 2010) and is suspected to be of great ecological relevance for the detection of harmful microbes by fruit flies (Stensmyr et al. 2012). In the light of the differences between yeasts and filamentous fungi I assume that the former present a more suitable food source. I hypothesise that the volatile bouquet of yeasts is more attractive and that yeasts are more accepted as food than filamentous fungi.

An additional focus of this study is on investigating the potential of fungal tissue wounding and related changes in fungal volatile profiles in affecting Collembola foraging decisions. While mechanical wounding/disruption of fungal tissue was shown to activate the emission of oxylipin volatiles in filamentous fungi (Brodhun and Feussner 2011. Combet et al. 2009. Fäldt et al. 1999. Wurzenberger and Grosch 1983) (Chapter 2, Subsection 2.4.1), a similar systemic response is unlikely for yeasts due to their unicellular structure and has never been described. As fungi are constantly exposed to grazing, the release of wound-activated oxylipin volatiles may have crucial significance in affecting the behaviour of fungivorous arthropods and fitness of both fungi and arthropods. In fact, some oxylipin volatiles were demonstrated to function as cues for different soil invertebrates from a distance (Holighaus and Rohlfs 2018), however, the results from Chapter 2 and Chapter 3 indicate that neither Collembola nor isopods change their searching behaviour (movement patterns) in response to increased headspace concentrations of oxylipins (3-octanone, 3-octyl acetate) in wounded colonies of the saprotrophic fungus C. globosum (Chapter 2, Chapter 3). However, wounded C. globosum colonies were more accepted as food source by F. candida, H. nitidus, and S. curviseta when direct contact was possible (Chapter 2, Subsection 2.4.3). Moreover, the oxylipin 3-octanone triggered test-biting behaviour in F. candida and S. curviseta (Chapter 2, Subsection 2.4.4). By including further species of filamentous fungi, the aim is to test in more detail whether Collembola searching patterns in principle remain unaffected by wounding-related changes in the fungal chemistry and whether an increase in oxylipin headspace concentrations in general increases the acceptance of wounded fungal colonies as food source. 


\subsection{Material And Methods}

\subsubsection{FUNGAL INCUBATION}

Fungal colonies used in the experiments were reared from conidia suspensions in case of filamentous fungi A. nidulans, T. harzianum, and P. expansum and cell suspensions in case of C. terricola, M. pulcherrima, and T. dulcitum yeasts. Due to differences in growth characteristics, yeasts and filamentous fungi were handled differently to obtain suspensions for the experiments.

Yeast cell cultures were initially raised until the saturation point in malt extract broth fluid culture (15 g malt extract; $2.5 \mathrm{~g}$ peptone; filled up with water to $500 \mathrm{ml}$ ) and stored in a refrigerator at $6^{\circ} \mathrm{C}$ in darkness. For the preparation of yeast cell cultures for the experiments, inactive saturated suspensions were reactivated by diluting them to a concentration of $10^{-1}$ with malt extract broth, thereupon fresh suspensions were incubated for 3 days at room temperature on a laboratory shaker (500 rpm), and afterwards, again diluted to a concentration of $10^{-1}$ with malt extract broth. Obtained suspensions were used for a maximum of 7 days for inoculation of yeast colonies for the experiments, and in the meantime, stored at $6^{\circ} \mathrm{C}$ in darkness.

Fungal colonies of A. nidulans, T. harzianum, and P. expansum were maintained by regular fresh inoculation and incubation on sterile malt extract agar (MEA) medium. Spore suspensions of these species were obtained by rinsing off conidia from established colonies with sterile Ringer solution. These raw suspensions were then stored at $6^{\circ} \mathrm{C}$. At the onset of an experiment, raw suspensions were diluted to the desired concentrations with Ringer solution.

For experiments sterile malt extract agar was inoculated with the respective cell or spore suspension and incubated at $20^{\circ} \mathrm{C}$ (climate chamber; Lovibond ${ }^{\circledR}$ ) in constant darkness. According to growth properties incubation times differed between fungal species (Table 4.1).

Genotypes A and B of P. expansum were provided by the Technical University of Denmark (Department of Biotechnology and Biomedicine) and correspond to identification numbers 30506 and 23705, respectively, as listed in the IBT culture collection. 
Table 4.1: Fungal species and genotypes used in experiments.

\begin{tabular}{|c|c|c|c|c|c|}
\hline Phylum & Species & Genotype & Growth stage & Incubation time & Experiments ${ }^{(*}$ \\
\hline \multirow[t]{4}{*}{ Ascomycota } & \multirow[t]{4}{*}{ Aspergillus nidulans } & \multirow[t]{2}{*}{ veA+ } & vegetative & 8 days & $\mathrm{a}$ \\
\hline & & & sporulating & 10 days & $\mathrm{a}$ \\
\hline & & \multirow[t]{2}{*}{ veA1 } & vegetative & 8 days & $\mathrm{a}$ \\
\hline & & & sporulating & 10 days & $a, b, c, d$ \\
\hline \multirow[t]{2}{*}{ Ascomycota } & \multirow[t]{2}{*}{ Trichoderma harzianum } & \multirow[t]{2}{*}{$\mathrm{T} 12$} & vegetative & 4 days & $\mathrm{a}$ \\
\hline & & & sporulating & 8 days & $a, b, c, d$ \\
\hline \multirow[t]{4}{*}{ Ascomycota } & \multirow[t]{4}{*}{ Penicillium expansum } & \multirow[t]{2}{*}{ A } & vegetative & 2 days & $\mathrm{a}$ \\
\hline & & & sporulating & 4 days & $a, b, c, d$ \\
\hline & & \multirow[t]{2}{*}{ B } & vegetative & 2 days & $\mathrm{a}$ \\
\hline & & & sporulating & 4 days & $\mathrm{a}$ \\
\hline Ascomycota & Metschnikowia pulcherrima & & & 4 days & $a, b, c, d$ \\
\hline Basidiomycota & Cryptococcus terricola & & & 4 days & $a, b, c, d$ \\
\hline Basidiomycota & Trichosporon dulcitum & & & 4 days & $a, b, c, d$ \\
\hline
\end{tabular}

\subsubsection{Culturing of F. candida Collembola}

F. candida Collembola cultures ('Berlin' strain) were maintained in the laboratory at $20{ }^{\circ} \mathrm{C}$ in constant darkness in Petri dishes (9 $\mathrm{cm}$ in diameter) on a mixture of plaster and activated charcoal (proportion 40:1). Aeration was ensured by providing the lids of the Petri dishes with a ventilation opening that was covered with fine mesh gauze. Once per week the Collembola were fed with dried baker's yeast and regular moistening prevented the animals from drying out. Adult individuals were transferred to new Petri dishes for oviposition to raise age-synchronized populations. The age of the Collembola used for behavioural observations ranged between 60 and 90 days. Young adults (25 days old), ready for oviposition and with potential for further increase in body size, were employed for the fitness experiment. Seven days before start of an experiment animals were deprived of food. 


\subsubsection{SPME-GC-MS VOLATILE PROFILING}

By means of the solid phase microextraction (SPME) technique (Pawliszyn 1997) in combination with gas chromatography-mass spectrometry (GC-MS) volatiles were sampled and identified from vegetative and sporulating colonies of filamentous fungi $A$. nidulans (two genotypes), T. harzianum, P. expansum (two genotypes), and C. terricola, M. pulcherrima, and T. dulcitum yeast colonies (Table 4.1) to reveal differences between and characteristics of volatile profiles from the two fungal life forms. Different genotypes and growth stages of filamentous fungi were analysed and, based on the highest diversity of volatile compounds, I chose one genotype and one growth stage per fungal species for behavioural observations and the fitness assay. In addition, the effect of tissue wounding on volatile emissions was investigated with respect to $A$. nidulans, T. harzianum, and P. expansum (including all genotypes and growth stages) (Table 4.1). Considering all species, genotypes, growth stages and the wounding treatment, there were 23 fungal treatments, each replicated six times. Evenly distributed over the GC-MS analysis period, volatile profiles of ten fungal-free MEA controls and one empty glass tube were measured.

Fungi were inoculated and incubated for different time periods (Table 4.1) in sterile glass tubes (150 mm in height, $30 \mathrm{~mm}$ in diameter) on $50 \mathrm{ml}$ MEA medium. To achieve optimal growth, A. nidulans, T. harzianum, and P. expansum were inoculated with $10 \mu \mathrm{l}$ conidia suspension (1000 conidia/ $\mu \mathrm{l}$ ) whereas C. terricola, M. pulcherrima, and T. dulcitum were inoculated with $50 \mu \mathrm{l}$ cell suspension (undefined cell concentration) as it turned out that these yeasts grow best in a moister environment. During incubation the glass tube samples were sealed with sterile aluminium foil to avoid contamination and ensure air exchange, and stored in separate boxes to prevent potential cross-influence by volatile leakage. Standardised wounding/disruption of fungal tissue was done by scratching a mesh pattern (four horizontal and four vertical scratches) with a thin wire loop without disrupting the culture medium. Approximately $50 \%$ of the fungal tissue were disrupted. The wounding treatment was done exactly 30 minutes before volatile sampling and immediately afterwards the glass tubes were sealed with parafilm to allow volatiles to accumulate. Untreated colonies and MEA controls were handled identically except from the wounding treatment. For sampling of volatiles from the fungal headspace, the SPME-fibre (StableFlexTM), with a thickness of 85 $\mu \mathrm{m}$ and CarboxenTM/Polydimethylsiloxane (PDMS) coating, was carefully stuck through the parafilm and exposed to the headspace for exactly 45 minutes. In preliminary GC-MS test runs a sampling period of 45 minutes turned out to be optimal to capture detectable 
amounts of low volatile compounds on the one hand, and allow clear differentiation between chromatogram peaks of high volatile compounds on the other.

Fungal volatile profiles were successively analysed by using a GC (Agilent Technologies, 6890N; Palo Alto, USA; non-polar HP-5ms column, $0.25 \mathrm{~mm}$ ID, $30 \mathrm{~m}$ length, $0.25 \mu \mathrm{m}$ film thickness) which was coupled to an MS (Agilent Technologies, 5973N; Palo Alto, USA; 20$345 \mathrm{amu}$, electron ionization at $70 \mathrm{eV}$ ). To cover a broad range of high and low volatile compounds and to achieve clear separation between compound peaks the initial GC temperature was set at $-30^{\circ} \mathrm{C}$ (hold for $1.5 \mathrm{~min}$ ), followed by a temperature ramp with $6{ }^{\circ} \mathrm{C}$ per minute up to $200{ }^{\circ} \mathrm{C}$, and maintenance of $200{ }^{\circ} \mathrm{C}$ for 3 minutes. Retention indices were obtained from retention times of target compounds and n-alkanes (C3-C18) by means of the Van den Dool and Kratz equation $\left(I_{x}=100 n+100\left(t_{x}-t_{n}\right) /\left(t_{n+1}-t_{n}\right) ; t_{x}\right.$ : retention time of target compound; $t_{n}, t_{n+1}$ : retention times of two consecutive n-alkanes eluted immediately before and after $t_{x}$ ). MSD ChemStation Data Analysis software (version D.02.00.275; Agilent Technologies), AMDIS (version 2.66; Geithersburg, MD), and Mass Finder 4 (Hochmuth et al., www.massfinder.com) were used to determine peak identities. Retention indices and mass spectra of target compounds were compared to literature retention values listed in the NIST Chemistry WebBook (NIST Standard Reference Database Number 69, http://webbook.nist.gov/chemistry/) and entries in mass spectral libraries NIST 08, Wiley 9, and Mass Finder 4 Terpenoids Library. In addition, chromatogram raw data was checked with the online software SpectConnect (Styczynski et al. 2007) to ensure that none of the compound peaks had been overlooked. For further verification, retention indices of target compounds were compared to those of authentic standards (if available) (Subsection 4.3.4), which were measured with identical GC parameters.

Headspace concentrations of the P. expansum characteristic compound geosmin were determined by means of an authentic standard calibration curve comprising four concentrations $\left(10^{-3}-10^{-6}\right)$ Figure A.4.1). $10 \mathrm{mg}$ of geosmin were solved in $100 \mu \mathrm{l}$ methanol. To obtain a concentration of $10^{-3}, 10 \mu \mathrm{l}$ of the geosmin-methanol solution were pipetted on the surface of $1000 \mu \mathrm{l}$ paraffin. After complete evaporation of the methanol (subsequently verified by GCMS analyses), the remaining geosmin was mixed in the paraffin with a vortex mixer to get a homogeneous solution. This initial solution was used to prepare the concentration series for the quantification of geosmin concentrations by GC-MS. The same geosmin solutions were subsequently used in the off-patch searching experiment Section 4.3.5. 


\subsubsection{AUTHENTIC STANDARDS FROM COMMERCIAL SUPPLIERS}

Following authentic standards were obtained from commercial suppliers and used for retention index-based identification of fungal derived volatile compounds. Furan (CAS: 11000-9), hexane (CAS: 110-54-3), 2-methyl-3-buten-2-ol (CAS: 115-18-4), 2-methyl-1-propanol (CAS: 78-83-1), 3-methyl-3-buten-2-ol (CAS: 763-32-6), 3-methyl-1-butanol (CAS: 123-51-3), 3-octanone (CAS: 106-68-3), 3-octanol acetate (CAS: 4864-61-3), 2-methylisoborneol (CAS: 2371-42-8), geosmin (CAS: 19700-21-1).

\subsubsection{EXPERIMENTAL SETUPS}

\section{SEARCHING PHASE: TRACKING OF COLLEMBOLA MOVEMENT IN RESPONSE TO FUNGAL COLONIES}

To test the hypothesis that Collembola are more strongly attracted to and/or arrested by the volatile bouquet of yeast fungi than by filamentous fungi, I investigated the volatilemediated movement of single Collembola in response to C. terricola, M. pulcherrima, and T. dulcitum colonies, and sporulating colonies of A. nidulans, T. harzianum, and P. expansum by video observation. It is further hypothesised that wound-activated changes in volatile profiles of A. nidulans, T. harzianum, and P. expansum (Subsection 4.4.1, Table 4.3) do not affect Collembola movement patterns.

Fungal colonies were incubated in sterile polypropylene cups $(7 \mathrm{~mm}$ in hight, $25 \mathrm{~mm}$ in diameter) on $3 \mathrm{ml}$ MEA for different time periods depending on fungal growth properties (Table 4.1). In case of $A$. nidulans and P. expansum inoculation volume was $10 \mu \mathrm{l}$ (1000 spores $/ \mu \mathrm{l}$ ), and with respect to T. harzianum which grows optimal in drier environments, $5 \mu \mathrm{l}$ spore suspension (2000 spores $/ \mu \mathrm{l}$ ) were used. In case of yeasts $50 \mu \mathrm{l}$ cell suspension were used for inoculation. Fungal-free MEA served as control. Wounding of fungal tissue was done as described above (Subsection 4.3.3). The experimental arena, a glass Petri dish with a diameter of $10.1 \mathrm{~cm}$ (Figure 4.1), was filled with $45 \mathrm{ml}$ water agar to create a surface which allows for unhindered movement and provides sufficient humidity. A fungal colony or fungal-free control was placed centrally in the arena immediately before start of the 15-minute recording. The arena was covered with a glass plate and a single Collembola 
was released at the outer edge of the arena and remained trapped in a glass tube for 2 minutes to acclimate. CyberLink PowerDirector ${ }^{\circledR}$ (CyberLink Corporation, Taipei, Taiwan) was used for recording. Recordings were carried out on several days with an equal number of observations per treatment per day (30 replicates, in total 300 recordings).

\section{SEARCHING PHASE: TRACKING OF COLLEMBOLA MOVEMENT IN RESPONSE TO GEOSMIN}

As Collembola arrival tendencies were significantly lower in the presence of both unwounded and wounded P. expansum colonies compared to medium controls (Section 4.4.2) it is hypothesised that the filamentous fungus $P$. expansum produces at least one volatile compound that has a deterrent effect on foraging F. candida individuals. GC-MS analysis revealed that, besides some sesquiterpenes, $P$. expansum emits four terpenoid compounds, namely geosmin (trans-1,10-dimethyl-trans-9-decalol), 2-methylisoborneol, and it's dehydration products 2-methyl-2-bornene and 2-methylenebornane (Martin et al. 1988a), that distinguish the volatile profile of $P$. expansum from that of other fungi considered in this study. The compounds geosmin and 2-methylisoborneol are produced by various fungi, streptomycetes, and algae, and are known for an earthy/musty smell (Mahmoud and Buettner 2016, Martin et al. 1988b). Geosmin was tested for affecting F. candida movement patterns and being responsible for the observed deterrence of Collembola by P. expansum colonies using the same experimental setup as described above (Section 4.3.5).

Responses of Collembola were observed in the presence of geosmin in a concentration of $10^{-3}$. The average headspace concentration of geosmin in chromatograms of unwounded and wounded P. expansum colonies is $25^{-4}$ Table A.4.1. In addition, a second much lower concentration $\left(10^{-5}\right)$ of geosmin was tested to find out how sensitive Collembola respond and if small amounts of this compound suffice to cause deterrence. As geosmin was initially solved in methanol and, after evaporation of methanol, further diluted with paraffin (for detailed preparation of dilutions see Subsection 4.3.3), the geosmin-paraffin dilutions used in this experiment were previously checked for methanol residues to prevent potential solvent-caused bias of Collembola responses. Before video recording, polypropylene cups ( $25 \mathrm{~mm}$ in diameter, $7 \mathrm{~mm}$ in height) were provided with circular pieces of absorbent filter paper (13 $\mathrm{mm}$ in diameter). The filter paper was soaked with $40 \mu \mathrm{l}$ of the respective solution. 


\section{CONTACT PHASE: OBSERVATION OF COLLEMBOLA ON-PATCH BEHAVIOUR IN RESPONSE TO FUNGAL COLONIES}

It is hypothesised that yeast fungi present a more suitable food resource for fungivorous arthropods than filamentous fungi and that higher suitability is reflected in higher acceptance of yeast as food by Collembola. To test this I investigated the on-patch behaviour (direct contact) of individual Collembola in response to C. terricola, M. pulcherrima, and T. dulcitum yeast colonies and sporulating colonies of filamentous fungi A. nidulans, T. harzianum, and P. expansum by means of video observation. Furthermore, it is hypothesised that fungal tissue wounding increases the acceptance of wounded colonies of A. nidulans, T. harzianum, and P. expansum as food source.

Fungal colonies were grown on circular pieces of absorbent filter paper (13 $\mathrm{mm}$ in diameter) (Macherey-Nagel, Germany; Type MN 85/70 BF, Ø 90 mm), which were previously dipped in sterile MEA and additionally coated with $80 \mu \mathrm{l}$ MEA by pipetting. The medium was inoculated with $10 \mu \mathrm{l}$ spore (1000 conidia/ $\mu \mathrm{l}$ ) or cell suspension with respect to filamentous fungi A. nidulans, and P. expansum, and yeasts. For optimal growth of T. harzianum colonies, $5 \mu \mathrm{l}$ spore suspension (2000 conidia/ $\mu \mathrm{l}$ ) were used for inoculation. Colonies were incubated in sterile Petri dishes ( $9 \mathrm{~cm}$ in diameter) which were stored in ventilated boxes. The boxes were provided with moist paper towels to prevent desiccation of fungal colonies. Fungalfree MEA controls were treated similarly. Incubation times depended on fungal growth properties (Table 4.1).

Using a Canon EOS 60D reflex camera coupled to a Zeiss Discovery V8 stereo microscope by a macro lens (17-70 mm/F2.8-4.5), 25-minute recordings of single Collembola with direct contact to the volatile source were carried out. With 20 replicates per treatment, the recordings were made on several days with the same number of observations per treatment per day. Petri dishes ( $3 \mathrm{~cm}$ in diameter), filled with $5 \mathrm{ml}$ water agar, were used as experimental arenas. Before start of a recording a new fungal colony or fungal-free medium control was placed in the centre of the arena and an animal was released outside of the colony. The wounding treatment in case of filamentous fungi was done immediately before recording using a thin wire loop. Nearly $50 \%$ of the fungal tissue were disrupted by scratching (two horizontal and two vertical scratches). During recording the arena was covered with a lid. 


\section{FITNESS RESPONSE TO FUNGAL DIETS (YEASTS AND FILAMENTOUS FUNGI)}

To test whether the decisions made by Collembola during the searching and contact phase of foraging are reflected in fitness parameters, single Collembola were confronted with fungal colonies of C. terricola, M. pulcherrima, T. dulcitum, A. nidulans, T. harzianum, and P. expansum for 12 days. In light of the finding that yeasts are more accepted as food source than filamentous fungi (Subsection 4.4.3), it is expected that growth (body size) and reproduction (number of eggs) is also higher in the presence of yeasts.

Fungi were grown on circular pieces of absorbent filter paper ( $5 \mathrm{~mm}$ in diameter), which were previously soaked with MEA medium. In case of C. terricola, M. pulcherrima, T. dulcitum, A. nidulans, and P. expansum the medium patches were inoculated with $10 \mu \mathrm{l}$ spore (1000 conidia/ $\mu \mathrm{l}$ ) or cell suspension, and in case of T. harzianum $5 \mu \mathrm{l}$ spore suspension (2000 conidia $/ \mu \mathrm{l}$ ) were used for inoculation. Fungi were incubated for different time periods due to differences in growth properties (Table 4.1). Experimental arenas were prepared as follows: polypropylene cups ( $25 \mathrm{~mm}$ in diameter, $7 \mathrm{~mm}$ in height) were filled with a mixture of plaster and activated charcoal (proportion 40:1; $4 \mathrm{ml} /$ cup). After hardening, the mixture was moistened with sterile water to prevent Collembola from drying out. One F. candida individual and one food patch (fungal colony or control patch) were added to the arena, which was then covered with fine mesh gauze and a lid with two air openings. Fungal-free MEA and nutrient-poor water agar served as controls. During the experimental period the substrate was moistened every 3 days and food patches were replaced once after 6 days before old colony patches were totally consumed. On the 6th and 12th day eggs were removed from arenas and counted. The body size of each animal was determined on the first and 12th day by means of a stereo microscope (Zeiss V8, Germany) and the computer software AxioVision (Zeiss, Germany). Animals that did not survive until the 12th day were excluded from the analysis. Each dietary treatment was replicated 15 times, viz. with respect to six fungal treatments and two control treatments, overall 120 samples were prepared. 


\subsubsection{SELECTION OF VARIABLES FOR CHARACTERISATION OF COLLEMBOLA FORAGING RESPONSES}

Table 4.2: Subject of the present study and overview on components of the food selection process (adapted from Dethier et al. (1960), (Schoonhoven et al. (2005), and Chapter 2). By assuming that the here tested fungal colonies emit volatiles that Collembola can use as cues for food selection, the volatile designations (third column) refer to behavioural responses of animals characterised by the measured variables (second column).

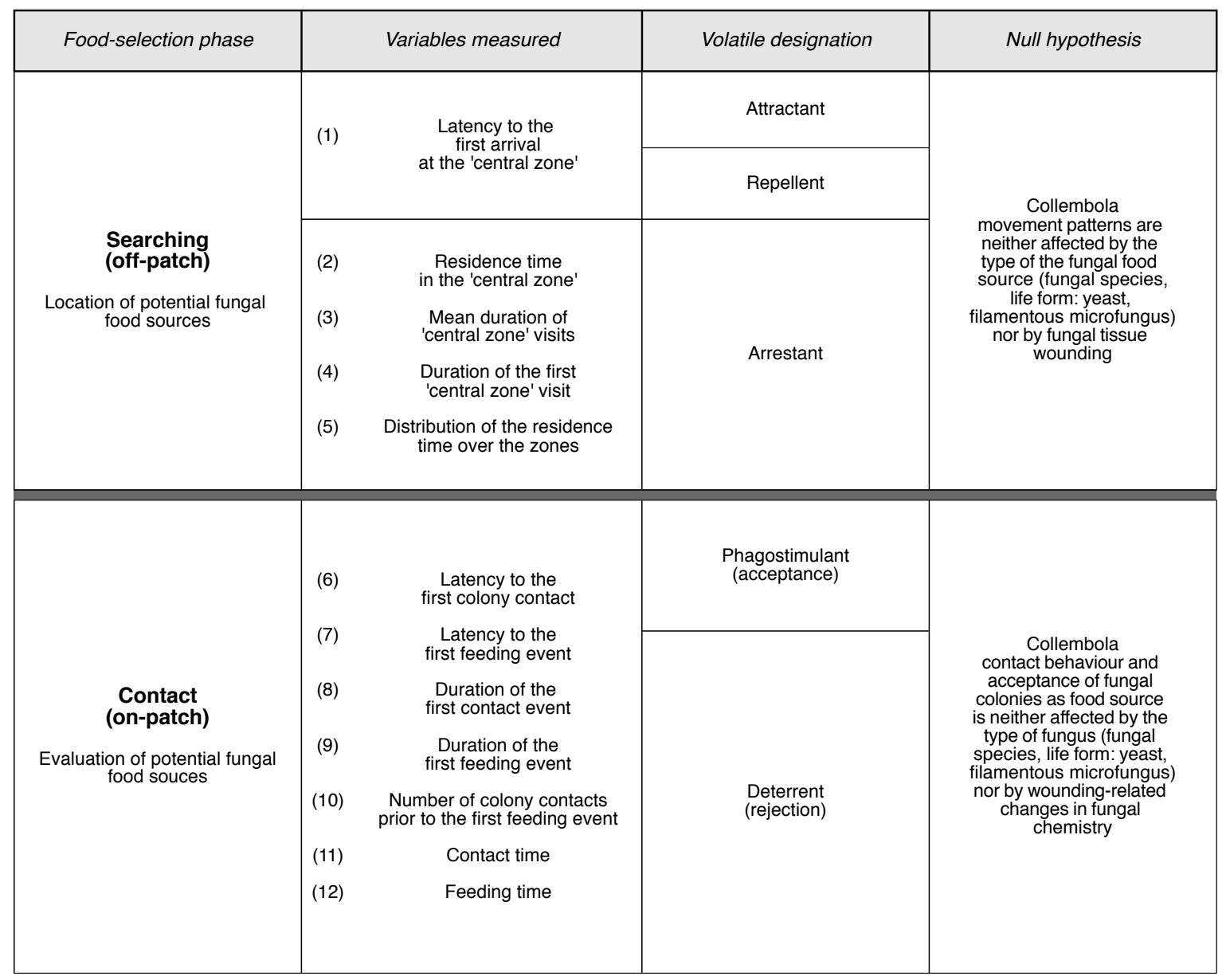

\section{SEARCHING PHASE: OFF-PATCH MOVEMENT PATTERNS}

Recordings were analysed with the semi-automated tracking software EthoVision ${ }^{\circledR} \mathrm{XT}$ (version 8.0; Noldus Information Technology, Wageningen, Netherlands) (Noldus et al. 2001). To get detailed information on Collembola movement patterns, the position of individual animals was tracked every 0.52 seconds in relation to a 'central zone' that was defined around the volatile source by means of the arena settings in EthoVision ${ }^{\circledR}$ XT. The remaining space of the arena was further divided into five zones (Figure 4.1). 
Following variables were selected to reveal attraction, avoidance, and/or arrestance: (1) 'latency to the first arrival at the central zone', (2) 'duration of the first central zone visit', (3) 'residence time in the central zone', (4) 'mean duration of central zone visits' (Table 4.2). If Collembola arrive faster or slower at the 'central zone' in comparison to the fungal-free control, they are assumed to be attracted or deterred respectively. A volatile source is assumed to have an arresting effect if the first 'central zone' visit is prolonged, the overall time spent in the 'central zone', and/or the 'mean duration of central zone visits' is longer in relation to the control. In addition, the 'distribution of residence time' over the predefined zones as a concentration gradient dependent variable was analysed. A deterrent effect of the volatile source is assumed if Collembola spent more time in outer zones of the experimental arena.

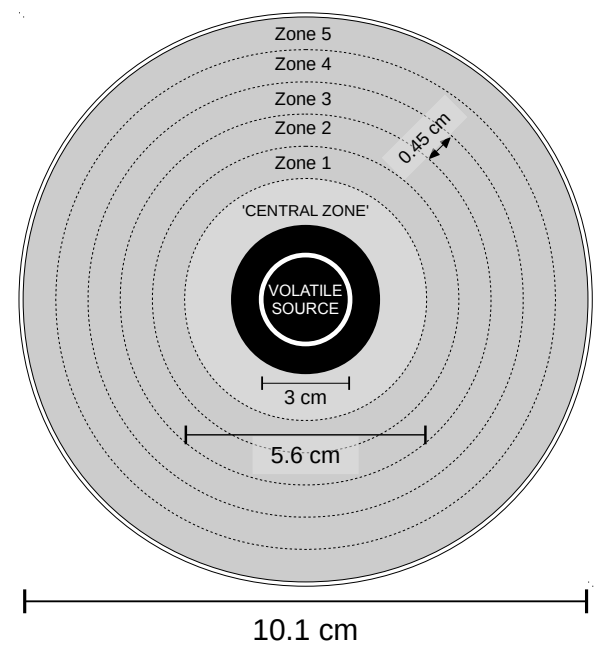

Figure 4.1: Dimensions of the experimental arena. A 'central zone' was defined around the volatile source. Background noise and disruptions of the automated tracking process in EthoVision $® X T$ were avoided by subtracting the area that encloses the volatile source (highlighted in black) from the arena by means of the 'arena settings'.

\section{CONTACT PHASE: ON-PATCH BEHAVIOUR}

The computer software Observer ${ }^{\circledR}$ XT (version 10.0, Noldus Information Technology BV, Wageningen, The Netherlands) (Noldus 1991) was used to analyse the video footage. To get detailed information on Collembola contact and feeding behaviour following behavioural components were evaluated: latency to the first contact and first feeding event, duration of the first feeding event, total contact and feeding time, and contact frequency prior to the first feeding event (regarding the time interval between start of observation and onset of 
feeding) (Table 4.2). In Chapter 2 these variables were demonstrated to be well suited for pointing out differences in the acceptance of fungal food sources by Collembola.

While the first contact with a patch can be assumed to be volatile-driven, subsequent behavioural responses of Collembola can be expected to be additionally driven by tactile and/or gustatory stimuli. Thus, if Collembola get in contact with a fungal colony more rapidly compared to controls, it is assumed that Collembola are attracted by the volatile bouquet of the respective fungus. If a fungus has an arresting effect, the animals are expected to spend a higher proportion of the observation time in contact compared to controls. Higher acceptance of a fungus as food source is assumed if Collembola start feeding faster and/or spend more time with feeding compared to the control. Contact with the resource patch was assumed when a part of the animal's body overlaps with the patch. Feeding activity was identified by short and jerky body movements and rhythmical up and down movements of the head while remaining stationary.

\subsubsection{STATISTICAL ANALYSIS}

GC-MS quantity data (manually integrated peak areas) of volatile compounds were compared between unwounded and wounded colonies of filamentous fungi using the WilcoxonMann-Whitney test ( $\alpha=0.05$, distribution='exact', function 'wilcox_test', package 'coin' in R) to reveal wounding-related changes in volatile profiles. Compounds occurring in blank samples were fully removed from the data set and medium-derived compounds were not included in the statistical analysis.

The Wilcoxon test was also applied to determine the effect of fungal life-form (yeasts vs. filamentous fungi) and tissue wounding (unwounded vs. wounded) on the 'residence time in the central zone', the 'mean duration of central zone visits' (searching phase), and the 'contact time' (contact phase). On fungal species level, these variables were analysed using the non-parametric Kruskal-Wallis test (function 'kruskal.test') for more than two treatment groups. In case of global significance, pairwise comparisons were done using Dunn's post hoc test (Dunn 1964) (function 'dunnTest', 'dunn.test.control'; package 'FSA') with Benjamini-Hochberg correction of p-values. When ties were present values were ranked randomly by using the 'rank' function in $\mathrm{R}$ before applying post hoc tests. In case of nonparametric statistics effect size is represented by Cohen's d. As recording times slightly 
differed with respect to the observation of the contact behaviour, the variables 'contact time' and 'feeding time' are given as percentage of the total observation time.

Cox regression models (function 'Coxph', package 'survival' in R) were applied on time dependent event data concerning the 'latency to the first arrival at the central zone', the 'duration of the first central zone visit' (searching phase), the 'latency to the first contact', the 'duration of the first contact', and the 'latency to the first feeding event' (contact phase). The assumption of proportionality was tested with goodness-of-fit $\tilde{\chi}^{2}$ tests along with an examination of partial residual plots (Schoenfeld 1980: 1982). As the 'duration of the first central zone visit' and the 'duration of the first contact' were intended to represent departure tendencies of Collembola, censoring was applied on 'visits' and 'contacts' that exceeded the observation time.

A generalized linear mixed effects model (function 'glmer', package 'lme4') with gamma distribution (log link function), fixed-effects of 'zone' and 'fungal species', and 'observation number' modelled as a random effect was applied to test for differences in the 'distribution of residence time' over the zones of the experimental arena between volatile sources (searching phase). As zeros were present within the continuous time data set, a value of 0.1 was added to each experimental value to meet the requirements of a gamma model. An analysis of variance (function 'Anova', package 'car') was applied on the mixed effects model to test for a significant global effect of the volatile source treatment.

The effect of fungal diets ('treatment') on the fitness parameter 'number of eggs' with zeroinflated and overdispersed count data was tested with a hurdle negative binomial regression model with 'logit' link function. In advance to this analysis an extensive model diagnosis was conducted, based on comparisons between possible error distributions, poisson or negative binomial, with respect to both zero-inflated (function 'zeroinfl', package 'pscl') and hurdle models (function 'hurdle', package 'pscl') by visual examination of diagnostic plots (residuals, Cook's D) and comparison of AIC and BIC values. Neither inclusion of the parameter 'growth' (change in body length) in the negative binomial part (positive count process) nor inclusion of 'treatment' in the truncated binomial part (zero count process) improved fit of the hurdle model, therefore both variables were excluded from the respective parts of the model. The final model was determined as follows: 'hurdle(no.eggs treatment I growth.x, link = "logit", dist = "negbin")' (the I separates the count model from the logistic model). Global significance was tested using the Wald test (function 'waldtest').

Analysis of the fitness parameter 'growth' (change in body length) in response to fungal 
dietary treatments was done using a generalized linear model with gamma error distribution and 'log' link function (function 'glm' in R). A likelihood ratio test was applied to test for global significance. Correlation between fitness parameters 'number of eggs' and 'change in body length' was tested with Pearson's product-moment correlation test (function 'cor.test').

\subsection{Results}

\subsubsection{GC-MS ANALYSIS - COMPARISON OF VOLATILE PROFILES}

Overall, 89 volatile compounds were determined from headspace samples of C. terricola, M. pulcherrima, and T. dulcitum yeasts, and vegetative and sporulating, unwounded and wounded colonies of A. nidulans (two genotypes), T. harzianum, and P. expansum (two genotypes) (Table 4.1) (Table A.4.2), after deduction of MEA medium derived compounds and artefacts of the chromatographic column. With regard to the presence and absence of these 89 compounds, striking differences were found between yeasts and filamentous fungi. With only 7 compounds, considerably less compounds where detected in yeast samples compared to filamentous fungi from which 84 compounds were determined. Whereas only alcohols and acetates were identified from yeast samples, the volatile profiles of the three filamentous fungi comprise alcohols, alkenes, aromatic compounds, ketones, terpenes, sesquiterpenes, and sesquiterpenoids (Table A.4.2).

Compound overlap between the two fungal life forms were found in case of 2-methyl-1propanol which was detected in samples of the yeast $M$. pulcherrima as well as in samples of filamentous fungi T. harzianum, and P. expansum, and in case of 3-methyl-1-butanol that was emitted by all species, genotypes and growth stages, except from sporulating colonies of T. harzianum (Table A.4.2).

Out of the three yeasts M. pulcherrima was the richest in volatiles with 3-octanol acetate, isoamyl acetate, isobutyl acetate, 2-methyl-1-propanol, 3-methyl-3-buten-1-ol, 3-methyl-1butanol, and phenylethyl alcohol. Only one compound, 3-methyl-1-butanol, was also detected in C. terricola and T. dulcitum (Table A.4.2). 
Similarly, only few compounds were detected in samples of the filamentous fungus A. nidulans. Whereas three compounds, 3-methyl-1-butanol, 3-octanone, and 1-octen-3-ol, were found in the headspace of the vegetative growth stage of the VeA1 genotype, only 3-methyl1-butanol was detected in sporulating colonies of this genotype (Table A.4.2). With respect to the vegetative stage 3-octanone (Wilcoxon-Mann-Whitney test, $z=-2.21, p=0.028$ ) and 1octen-3-ol (Wilcoxon-Mann-Whitney test, $\mathrm{z}=-2.21, p=0.028$ ) quantities significantly increased in response to wounding (Table A.4.3). Five further compounds were found to be woundactivated (Table 4.3). In case of the sporulating growth stage of $A$. nidulans seven compounds were found to be activated by wounding in the VeA1 genotype and six wound-activated compounds were identified from the VeA+ genotype (Table 4.3). The sporulating growth stage of the VeA1 genotype had been selected for further experiments.

Unlike $A$. nidulans, a large set of terpenes was detected in samples of filamentous fungi T. harzianum and P. expansum. Sporulating colonies of these species differentiate from vegetative colonies mainly by a larger number of terpenes (Table A.4.2).

Among all tested fungi, P. expansum was characterised by the emission of geosmin, 2-methylisoborneol, and it's dehydration products 2-methyl-2-bornene and 2-methylenebornane (Martin et al.1988a) (Table A.4.2). Overall, 33 compounds were detected in sporulating colonies of P. expansum genotype A and 29 compounds were found to derive from genotype B; thus, the sporulating growth stage of genotype A was selected for further experiments. With respect to this genotype, six compounds were found to be wound-activated (Table 4.3).

The volatile profile of the sporulating growth stage of $T$. harzianum comprised the largest number of volatile compounds among all tested fungi, in total 44 compounds (Table A.4.2). Whereas four compounds were only detected in samples of wounded colonies, abundances of the alcohol 1-octen-3-ol (Wilcoxon-Mann-Whitney test, $\mathrm{z}=-2.93, p=0.002$ ) and tentatively identified sesquiterpenes $\beta$-funebrene (Wilcoxon-Mann-Whitney test, $\mathrm{z}=-2.08, p=0.041$ ) and nardosina-9,11-diene (Wilcoxon-Mann-Whitney test, $\mathrm{z}=-2.40, p=0.015$ ) as well as abundances of an unidentified compound ('unknown (26)') (Wilcoxon-Mann-Whitney test, $z=-2.08$, $p=0.041$ ) were increased in response to fungal tissue wounding (Table 4.3, Table A.4.3). 
Table 4.3: Overview of wound-activated volatile compounds that were exclusively found in headspace samples of wounded colonies $(\star)$, increased $(\mathbf{\Lambda})$, or no longer detected $(0)$.

\begin{tabular}{|c|c|c|c|c|c|c|c|c|c|c|}
\hline & \multicolumn{4}{|c|}{ A. nidulans } & \multicolumn{4}{|c|}{ P. expansum } & \multicolumn{2}{|c|}{ T. harzianum } \\
\hline & \multicolumn{2}{|c|}{ VeA1 } & \multicolumn{2}{|c|}{ VeAt } & \multicolumn{2}{|c|}{ A } & \multicolumn{2}{|c|}{ B } & & \\
\hline & veg & spo & veg & spo & veg & spo & veg & spo & veg & spo \\
\hline 1-octen-3-ol & $\Delta$ & $\star$ & $\Delta$ & $\star$ & $\Delta$ & $\star$ & $\star$ & $\star$ & $\star$ & $\Delta$ \\
\hline 1-octen-3-ol acetate & $\star$ & $\star$ & $\star$ & $\star$ & & & & & & \\
\hline 1,3-octadiene & $\star$ & $\star$ & $\star$ & $\star$ & $\star$ & $\star$ & $\star$ & $\star$ & $\star$ & $\star$ \\
\hline 1,3-trans-5-trans-octatriene & $\star$ & $\star$ & $\star$ & $\star$ & 夫 & $\star$ & $\star$ & $\star$ & & $\star$ \\
\hline 2,4,6-octatriene & $\star$ & $\star$ & $\star$ & $\star$ & * & $\star$ & $\star$ & $\star$ & & $\star$ \\
\hline 3,3,5-trimethyl-2-hexene & $\star$ & $\star$ & $\star$ & $\star$ & $\star$ & $\star$ & $\star$ & $\star$ & & \\
\hline 3-octanone & $\Delta$ & $\star$ & $\star$ & & $\Delta$ & $\star$ & $\star$ & $\star$ & & $\star$ \\
\hline 2-methyl-1-propanol & & & & & $\circ$ & & & & & \\
\hline 2-methylenebornane & & & & & & & & $\Delta$ & & \\
\hline trans- $\beta$-bergamotene & & & & & & & & & $\Delta$ & \\
\hline$\beta$-funebrene & & & & & & & & & & $\Delta$ \\
\hline Nardosina-9,11-diene & & & & & & & & & & $\Delta$ \\
\hline Unknown (26) & & & & & & & & & & $\Delta$ \\
\hline
\end{tabular}

\subsubsection{THE SEARCHING PHASE OF FOOD SELECTION}

\section{EFFECT OF FUNGAL SPECIES}

With focus on the response of $F$. candida to fungal species, significant global effects were found with respect to the 'latency to the first arrival at the central zone' (arrival tendency) (Cox regression, likelihood ratio test, $\tilde{\chi}^{2}=15.29, \mathrm{df}=6, p=0.018$ ) and the 'residence time in the central zone' (Kruskal-Wallis test, $\tilde{\chi}^{2}=19.38, \mathrm{df}=6, p=0.004$ ). Relative to the control group the tendency to arrive at 'central zones' of P. expansum colonies was significantly lower and only half as high with a hazard ratio of 0.49 , however, no significant differences were found between the control treatment and the fungal species A. nidulans, T. harzianum, C. terricola, M. pulcherrima, and T. dulcitum (Table 4.4, Figure 4.2). The 'residence time in the central zone' of the yeast $C$. terricola was significantly higher compared to controls (Table 4.5, Figure 4.3a). An overall effect of the fungal species was also observed with respect to the 'mean duration of central zone visits' (Kruskal-Wallis test, $\tilde{\chi}^{2}=21.03, \mathrm{df}=6, p=0.002$ ) with a trend towards higher mean visit durations in the presence of $C$. terricola $(140.04 \mathrm{sec}, \mathrm{sd}=183.77 \mathrm{sec})$ and the filamentous fungus $A$. nidulans $(172.34 \mathrm{sec}, \mathrm{sd}=258.57 \mathrm{sec}$ ) compared to controls (51.79 sec, sd=97.32 sec) (Table 4.5). The tendency to leave the central zone subsequent to the first 
central zone visit ('duration of the first central zone visit') (Cox regression, likelihood ratio test, $\tilde{\chi}^{2}=3.2, \mathrm{df}=6, p=0.784$ ) and the 'distribution of the residence time' over the predefined zones (Gamma regression, ANOVA Type II, $\tilde{\chi}^{2}=1.80, \mathrm{df}=6, p=0.937$ ) were not affected by fungal species.

Table 4.4: Searching phase: Cox regression test statistic for time-dependent variables 'latency to the first arrival at the central zone' (arrival tendency) and 'duration of the first central zone visit' (departure tendency) in response to filamentous fungi A. nidulans (VeA1), T. harzianum, and P. expansum (A), and yeasts C. terricola, M. pulcherrima, and T. dulcitum. $\exp (\text { coef })^{(*)}$ gives the risk of the respective event in relation to the MEA control group.

\begin{tabular}{|c|c|c|c|c|c|c|}
\hline Species & Behavioural variable & $n$ & Events & $Z$ & $\exp (c o e f)^{(*)}$ & $P$-value \\
\hline MEA control & First arrival & 30 & 26 & & & \\
\hline A. nidulans & First arrival & 30 & 25 & -0.74 & 0.81 & 0.457 \\
\hline T. harzianum & First arrival & 30 & 26 & -0.14 & 0.96 & 0.892 \\
\hline P. expansum & First arrival & 30 & 20 & -2.38 & 0.49 & 0.017 \\
\hline C. terricola & First arrival & 30 & 27 & 1.09 & 1.35 & 0.277 \\
\hline M. pulcherrima & First arrival & 30 & 29 & 0.60 & 1.18 & 0.548 \\
\hline T. dulcitum & First arrival & 30 & 27 & -0.12 & 0.97 & 0.902 \\
\hline MEA control & Duration first visit & 26 & 25 & & & \\
\hline A. nidulans & Duration first visit & 25 & 23 & -1.47 & 0.65 & 0.143 \\
\hline T. harzianum & Duration first visit & 26 & 24 & -1.10 & 0.73 & 0.270 \\
\hline P. expansum & Duration first visit & 20 & 19 & -0.78 & 0.79 & 0.434 \\
\hline C. terricola & Duration first visit & 27 & 26 & -1.24 & 0.70 & 0.216 \\
\hline M. pulcherrima & Duration first visit & 29 & 25 & -1.40 & 0.67 & 0.163 \\
\hline T. dulcitum & Duration first visit & 27 & 25 & -0.52 & 0.86 & 0.604 \\
\hline
\end{tabular}




\section{CHAPTER 4}

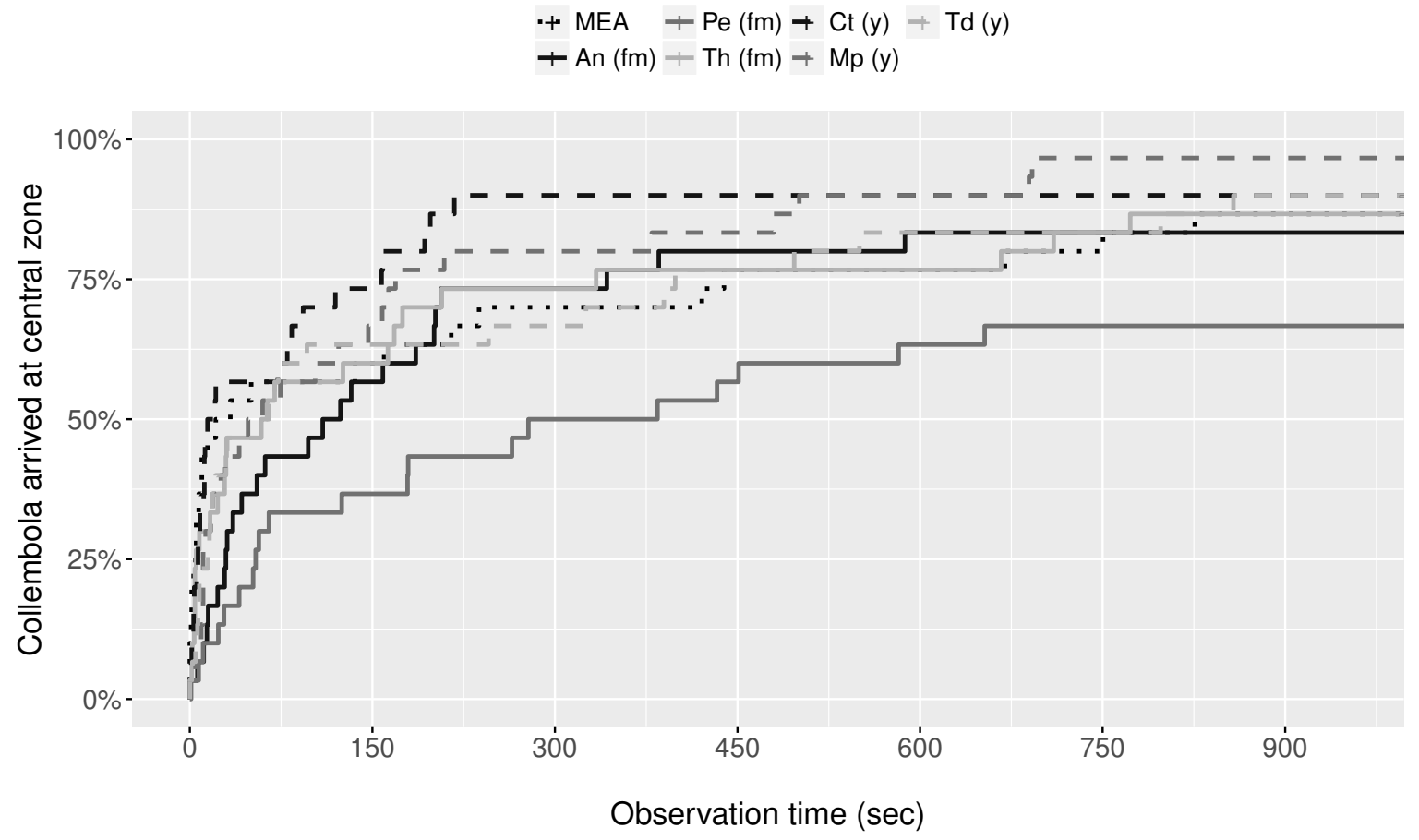

Figure 4.2: Kaplan Meier curves of F. candida 'first arrival at the central zone' in response to filamentous fungi (fm) A. nidulans (An), T. harzianum (Th), and P. expansum (Pe), yeasts (y) C. terricola (Ct), M. pulcherrima $(\mathrm{Mp})$, and T. dulcitum (Td), and MEA controls (MEA) within an observation period of 15 minutes.

Table 4.5: Searching phase: test statistic of pairwise comparisons using Dunn's test with respect to the 'residence time in the central zone' and the 'mean duration of central zone visits' in response to fungal species. In case of same sample size the effect size is represented by Cohen's $d$ and in case of different sample size Hedge's $\mathrm{g}$ is given, with $95 \%$ confidence interval.

\begin{tabular}{|c|c|c|c|c|c|c|}
\hline Behavioural variable & Comparison & $N$ & $Z$ & Effect size $(C I)$ & $P$-value & $(*)$ \\
\hline Time in zone & Control - A. nidulans & 60 & 1.33 & $0.48(-0.05,1.00)$ & 0.237 & \\
\hline Time in zone & Control - T. harzianum & 60 & 1.33 & $0.41(-0.11,0.93)$ & 0.237 & \\
\hline Time in zone & Control - P. expansum & 60 & 1.08 & $-0.14(-0.66,0.38)$ & 0.280 & \\
\hline Time in zone & Control - C. terricola & 60 & 2.87 & $0.90(0.36,1.44)$ & 0.024 & $\Delta$ \\
\hline Time in zone & Control - M. pulcherrima & 60 & 1.89 & $0.57(0.04,1.10)$ & 0.178 & \\
\hline Time in zone & Control - T. dulcitum & 60 & 1.29 & $0.42(-0.11,0.94)$ & 0.237 & \\
\hline Mean visit duration & Control - A. nidulans & 51 & 2.23 & $0.61(0.04,1.19)$ & 0.075 & \\
\hline Mean visit duration & Control - T. harzianum & 52 & 1.80 & $0.49(-0.07,1.06)$ & 0.143 & \\
\hline Mean visit duration & Control - P. expansum & 46 & 1.42 & $0.17(-0.43,0.77)$ & 0.233 & \\
\hline Mean visit duration & Control - C. terricola & 53 & 2.40 & $0.59(0.02,1.15)$ & 0.075 & \\
\hline Mean visit duration & Control - M. pulcherrima & 55 & 0.81 & $0.51(-0.04,1.06)$ & 0.421 & \\
\hline Mean visit duration & Control - T. dulcitum & 53 & 0.93 & $0.30(-0.26,0.85)$ & 0.420 & \\
\hline
\end{tabular}

(*) Referred to the second entry in the column 'Comparison' $\mathbf{\Delta}$ indicates a significant increase in the respective variable. 
(a)

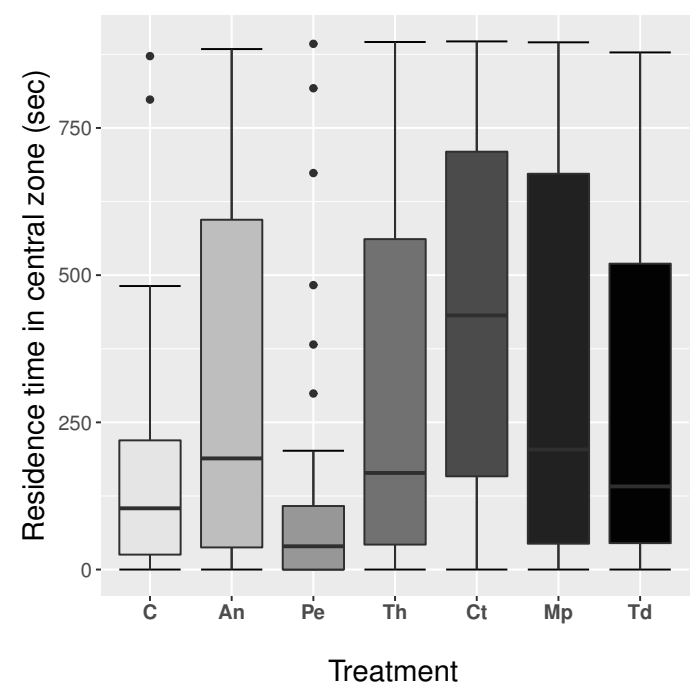

(b)

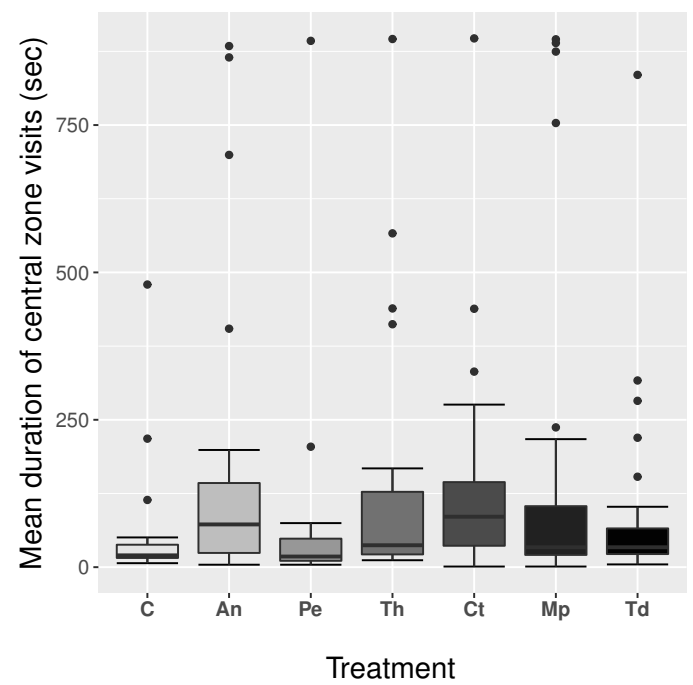

Figure 4.3: F. candida (a) 'residence time in the central zone' and (b) 'mean duration of central zone visits' in response to filamentous fungi A. nidulans (An), T. harzianum (Th), and P. expansum (Pe), yeasts $\mathrm{C}$. terricola $(\mathrm{Ct})$, M. pulcherrima (Mp), and T. dulcitum (Td), and MEA controls (C) within an observation period of 15 minutes.

\section{FILAMENTOUS FUNGI VS. YEASTS}

Analysis of Collembola responses to yeasts and filamentous fungi (pooled data) revealed significant effects of the fungal life form on the 'latency to the first arrival at the central zone' and the 'residence time in the central zone' (Table 4.6). The tendency to arrive at the 'central zone' was 1.6 times higher in the presence of yeasts and Collembola spent significantly more time in the 'central zone' in the presence of yeasts compared to filamentous fungi. The tendency to leave the patch after the first 'central zone' visit ('duration of the first central zone visit'), the 'mean duration of central zone visits', and the 'distribution of the residence time' over the predefined zones were not affected by the fungal life form Table 4.6. Figure 4.4). However, when the most attractive yeast, $C$. terricola, and the most unattractive filamentous fungus, P. expansum, were excluded from the analysis, the effect of the fungal group on both the arrival tendency (Cox regression, likelihood ratio test, $\tilde{\chi}^{2}=1.08, \mathrm{df}=1$, $p=0.299$ ) and residence time (Wilcoxon-Mann-Whitney test, $\mathrm{z}=-0.37, \mathrm{df}=1, p=0.713$ ) was not significant anymore. 
Table 4.6: Searching phase: test statistic for 'latency to the first arrival at the central zone' (arrival tendency), 'duration of the first central zone visit' (departure tendency) (Cox regression), 'residence time in the central zone', 'mean duration of central zone visits' (Wilcoxon test), and 'distribution of the residence time' (Gamma regression, ANOVA Type II) in response to fungal life forms (yeasts vs. filamentous fungi, pooled data). For Cox and Gamma regression models the $\tilde{\chi}^{2}$ value and for Wilcoxon tests the $Z$-score is given. Effect size is represented by the hazard ratio $\left(\exp (\text { coef })^{(*)}\right)$ and Cohen's $d$ or Hedge's g, with $95 \%$ confidence interval.

\begin{tabular}{l|ccccc|cc}
\hline Behavioural variable & $N$ & Events & $D f$ & $\tilde{\chi}^{2} / Z$ & Effect size $(C I)$ & $P-$ value & $(*)$ \\
\hline First arrival & 180 & 154 & 1 & 8.34 & 1.60 & $\mathbf{0 . 0 0 4}$ & $\boldsymbol{\Delta}$ \\
Duration first visit & 154 & 142 & 1 & 0.03 & 1.03 & 0.872 \\
\hline Time in zone & 180 & & 1 & 2.57 & $0.35(0.05,0.64)$ & $\mathbf{0 . 0 1 0}$ & $\boldsymbol{\Delta}$ \\
Mean visit duration & 154 & & 1 & 0.80 & $0.01(-0.31,0.33)$ & 0.428 & \\
\hline Distribution residence time & 180 & & 1 & 0.58 & & 0.446 \\
\hline
\end{tabular}

Given effect sizes relate to the yeast group. With respect to the first arrival a value greater than 1 indicates higher arrival tendency in the yeast group compared to the filamentous fungi group, and a value smaller than 1 lower arrival tendency, respectively. Regarding the 'duration of the first central zone visit' a value smaller than 1 indicates higher tendency for remaining (lower departure tendency) in the yeast 'central zones' compared to filamentous fungi.

${ }^{(*)}$ With reference to the yeast group $\boldsymbol{\Delta}$ indicates a significant increase in the respective variable compared to filamentous fungi group.

(a)

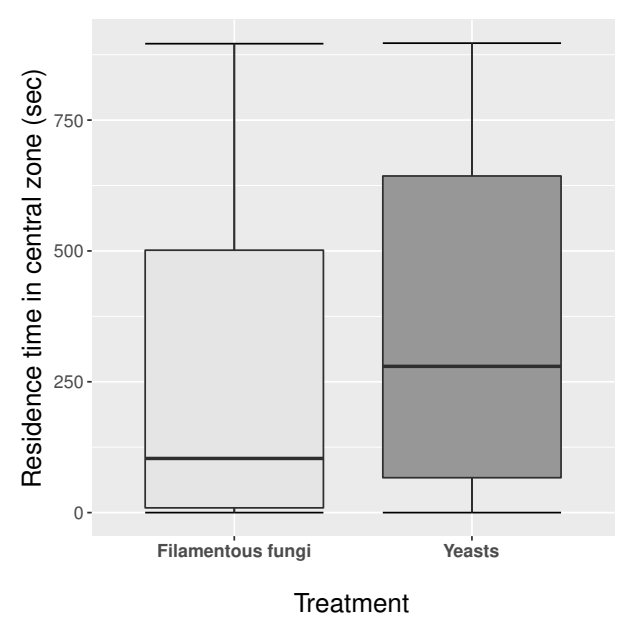

(b)

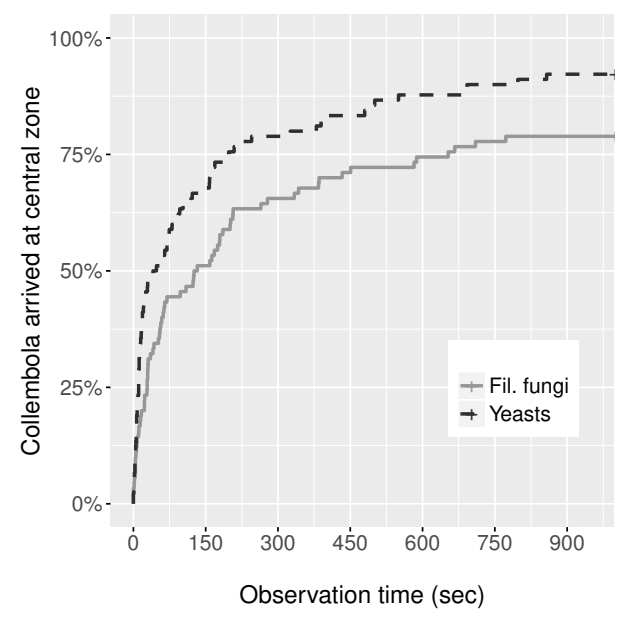

Figure 4.4: F. candida (a) 'residence time in the central zone' and (b) Kaplan Meier curves for the 'first arrival at the central zone' in response to fungal life forms (yeasts vs. filamentous fungi, pooled data) within an observation period of 15 minutes.

\section{UNWOUNDED VS. WOUNDED COLONIES OF FILAMENTOUS FUNGI}

None of the examined variables was affected by the wounding treatment, neither in case of pooled data (Table 4.7) nor when focussing on fungal species A. nidulans, P. expansum, and T. harzianum separately (Table 4.8). However, there is a clear trend towards higher arrival tendencies in the presence of unwounded colonies (Table 4.7, Figure 4.5). 


\section{CHAPTER 4}

VOLATILE-MEDIATED FORAGING RESPONSES TO YEASTS AND FILAMENTOUS FUNGI CORRELATE WITH FUNGIVORE GROWTH AND REPRODUCTION

Table 4.7: Searching phase: test statistic for 'latency to the first arrival at the central zone' (arrival tendency), 'duration of the first central zone visit' (departure tendency) (Cox regression), 'residence time in the central zone', and 'mean duration of central zone visits' (Wilcoxon test), and the 'distribution of the residence time' over zones (Gamma regression, ANOVA Type II) in response to unwounded and wounded colonies of filamentous fungi (pooled data). For Cox and Gamma regression models $\tilde{\chi}^{2}$ values and for Wilcoxon tests the $Z$-score is given. Effect size is represented by the hazard ratio $\left(\exp (\operatorname{coe} f)^{(*)}\right)$ and Cohen's $d$ or Hedge's g, with 95\% confidence interval.

\begin{tabular}{l|ccccc|c}
\hline Behavioural variable & $N$ & Events & $D f$ & $\tilde{\chi}^{2} / Z$ & Effect size $($ CI $)$ & $P-$ value \\
\hline First arrival & 180 & 132 & 1 & 3.21 & 0.73 & 0.073 \\
Duration first visit & 132 & 122 & 1 & 0.62 & 0.87 & 0.432 \\
\hline Time in zone & 180 & & 1 & -0.60 & $-0.07(-0.37,0.22)$ & 0.549 \\
Mean visit duration & 132 & & 1 & 0.65 & $-0.02(-0.35,0.31)$ & 0.517 \\
\hline Distribution of time & 180 & & 1 & 0.03 & & 0.863 \\
\hline
\end{tabular}

Given effect sizes relate to the wounding treatment group. With respect to the first arrival a value greater than 1 indicates higher arrival tendency in the wounding treatment group, and a value smaller than 1 lower arrival tendency, respectively. Regarding the 'duration of the first central zone visit' a value smaller than 1 indicates higher tendency for remaining (lower departure tendency) in 'central zones' of wounded colonies.

Table 4.8: Searching phase: test statistic for 'latency to the first arrival at the central zone' (arrival tendency), 'duration of the first central zone visit' (departure tendency) (Cox regression), 'residence time in the central zone', 'mean duration of central zone visits' (Wilcoxon test), and the 'distribution of the residence time' over the zones (Gamma regression, ANOVA Type II) in response to unwounded and wounded colonies of filamentous fungi (separate analysis per fungal species). For Cox and Gamma regression models the $\tilde{\chi}^{2}$ value and for Wilcoxon tests the $Z$-score is given. Effect size is represented by the hazard ratio $\left(\exp (\operatorname{coe} f)^{(*)}\right)$ and Cohen's $d$ or Hedge's g, with 95\% confidence interval.

\begin{tabular}{ll|lcccc|c}
\hline Species & Behavioural variable & $N$ & Events & $D f$ & $\tilde{\chi}^{2} / Z$ & Effect size $($ CI $)$ & $P-$ value \\
\hline A. nidulans & First arrival & 60 & 46 & 1 & 1.51 & 0.69 & 0.219 \\
P. expansum & First arrival & 60 & 37 & 1 & 0.33 & 0.83 & 0.567 \\
T. harzianum & First arrival & 60 & 49 & 1 & 2.04 & 0.66 & 0.154 \\
A. nidulans & Duration first visit & 46 & 43 & 1 & 0.11 & 1.11 & 0.741 \\
P. expansum & Duration first visit & 37 & 35 & 1 & 0.65 & 0.76 & 0.421 \\
T. harzianum & Duration first visit & 49 & 44 & 1 & 0.69 & 0.78 & 0.407 \\
\hline A. nidulans & Time in zone & 60 & & 1 & 0.01 & $0.13(-0.39,0.65)$ & 0.991 \\
P. expansum & Time in zone & 60 & & 1 & -0.27 & $0.01(-0.51,0.52)$ & 0.789 \\
T. harzianum & Time in zone & 60 & & 1 & -0.53 & $0.15(-0.66,0.37)$ & 0.601 \\
A. nidulans & Mean visit duration & 46 & & 1 & 0.39 & $-0.08(-0.68,0.51)$ & 0.710 \\
P. expansum & Mean visit duration & 37 & & 1 & 0.55 & $0.03(-0.63,0.70)$ & 0.598 \\
T. harzianum & Mean visit duration & 49 & & 1 & 0.40 & $0.05(-0.53,0.62)$ & 0.699 \\
\hline A. nidulans & Distribution of time & 60 & & 1 & 0 & & 1.000 \\
P. expansum & Distribution of time & 60 & & 1 & 0.08 & & 0.776 \\
T. harzianum & Distribution of time & 60 & & 1 & 0.02 & & 0.896 \\
\hline
\end{tabular}

Given effect sizes relate to the wounded treatment group. 
(a)

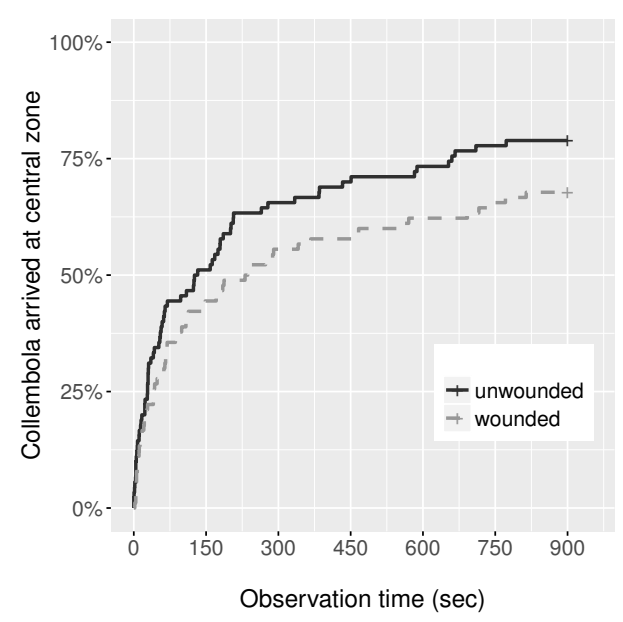

(b)

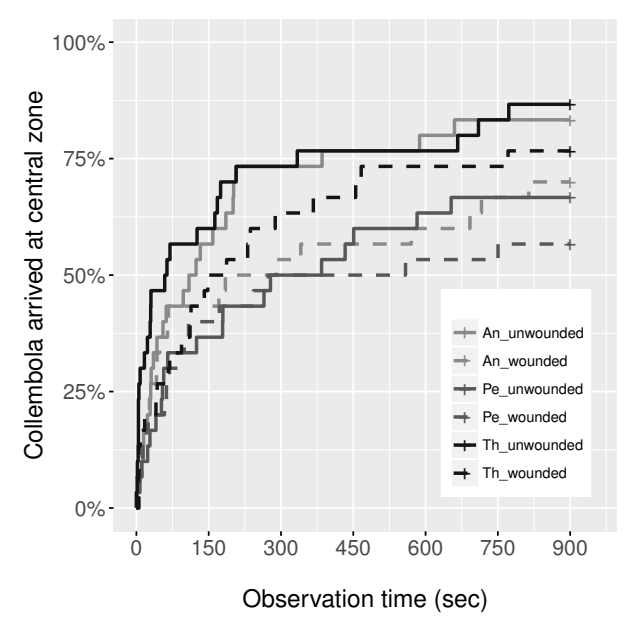

Figure 4.5: Kaplan-Meier curves for F. candida first arrival at the 'central zone' in response to unwounded and wounded colonies of filamentous fungi within an observation period of 15 minutes. Presentation on (a) treatment level (pooled data across species) and (b) species level (An: A. nidulans; Pe: P. expansum; Th: T. harzianum.

\section{COLLEMbOLA RESPONSES TO GEOSMIN}

Collembola movement patterns were affected by the P. expansum characteristic volatile compound geosmin. Significant global effects were found with respect to the 'first arrival at the central zone' (Cox regression, likelihood ratio test, $\tilde{\chi}^{2}=12.10, \mathrm{df}=2, p=0.002$ ) and the 'residence time in the central zone' (Kruskal-Wallis test, $\tilde{\chi}^{2}=8.80, \mathrm{df}=2, p=0.012$ ). With an inverted hazard ratio of 4.33 (1/0.23) Collembola arrival tendency was more than four times higher in the presence of the solvent control than the tendency in presence of the high concentration of geosmin (Table 4.9, Figure 4.6). Further, Collembola spent significantly less time in the 'central zone' of the high concentration of geosmin compared to controls (Table 4.10. Figure 4.6. In contrast, the time spent in the 'central zone' of the low concentration of geosmin was not different to controls, but significantly higher compared to the high concentration of geosmin (Table 4.10). A global effect of the geosmin treatment was also found with respect to the 'distribution of residence time' over the predefined zones (Gamma regression, ANOVA Type II, $\tilde{\chi}^{2}=13.76, \mathrm{df}=2, p=0.001$ ). The distribution did not differ from the solvent control in case of the low concentration of geosmin $(t=0.86, p=0.390)$, but a significant difference was found between the control and the high concentration of geosmin $(\mathrm{t}=-2.75, p=0.006)$. Whereas Collembola spent the majority of the observation time in outer 
zones, most notably in the border zone of the arena, and hardly in zones close to the volatile source ('central zone', 'zone 1'), in presence of the solvent control the residence time was distributed more evenly over the zones with significant residence also in zones close to the volatile source (Figure 4.7). The 'duration of the first central zone visit' (Cox regression, likelihood ratio test, $\tilde{\chi}^{2}=0.09, \mathrm{df}=2, p=0.956$ ), and the 'mean duration of central zone visits' were not affected by geosmin (Kruskal-Wallis test, $\tilde{\chi}^{2}=0.61, \mathrm{df}=2, p=0.731$ ).

Table 4.9: Searching phase: test statistic for 'latency to the first arrival at the central zone' (arrival tendency), 'duration of the first central zone visit' (departure tendency) in response to the P. expansum characteristic compound geosmin.

\begin{tabular}{|c|c|c|c|c|c|c|c|}
\hline Treatment & Behavioural variable & $n$ & Events & $Z$ & $\exp (\text { coef })^{(*)}$ & $P$-value & $(* *)$ \\
\hline Solvent control & First arrival & 20 & 10 & & & & \\
\hline Geosmin $10^{-3}$ & First arrival & 20 & 3 & -2.22 & 0.23 & 0.026 & $\nabla$ \\
\hline Geosmin $10^{-5}$ & First arrival & 20 & 13 & 1.02 & 1.53 & 0.309 & \\
\hline Solvent control & Duration first visit & 10 & 8 & & & & \\
\hline Geosmin $10^{-3}$ & Duration first visit & 3 & 2 & -0.24 & 0.83 & 0.812 & \\
\hline Geosmin $10^{-5}$ & Duration first visit & 13 & 10 & -0.25 & 0.89 & 0.800 & \\
\hline
\end{tabular}

(*) With respect to the first arrival a value greater than 1 indicates higher arrival tendency in a treatment group in comparison to the control, and a value smaller than 1 lower arrival tendency, respectively. Regarding the 'duration of the first central zone visit' a value smaller than 1 indicates higher tendency for remaining (lower departure tendency) in the 'central zone' in the presence of geosmin compared to the control group.

$(* *)$ Compared to the control group $\nabla$ indicates a significant decrease in the respective variable.

Table 4.10: Searching phase: test statistic of pairwise comparisons using Dunn's test for multiple comparisons of means with respect to the 'residence time in the central zone' in response to geosmin. Effect size is represented by Cohen's d, with 95\% confidence interval.

\begin{tabular}{ll|ccc|cc}
\hline Variable & Comparison & $N$ & $Z$ & Effect size $($ CI $)$ & $P-$ value & $(*)$ \\
\hline Time in zone & Control - Geosmin $10^{-3}$ & 40 & -2.47 & $-0.22(-0.86,0.42)$ & $\mathbf{0 . 0 2 0}$ & $\nabla$ \\
Time in zone & Control - Geosmin $10^{-5}$ & 40 & 1.21 & $0.30(-0.35,0.94)$ & 0.227 & \\
Time in zone & Geosmin $10^{-3}-$ Geosmin $10^{-5}$ & 40 & 3.68 & $0.54(-0.12,1.19)$ & $<\mathbf{0 . 0 0 1}$ & $\boldsymbol{\Delta}$ \\
\hline
\end{tabular}

${ }^{(*)}$ Referred to the second entry in the column 'Comparison' $\mathbf{\Delta}$ indicates a significant increase and $\nabla$ a significant decrease in the respective variable. 
(a)

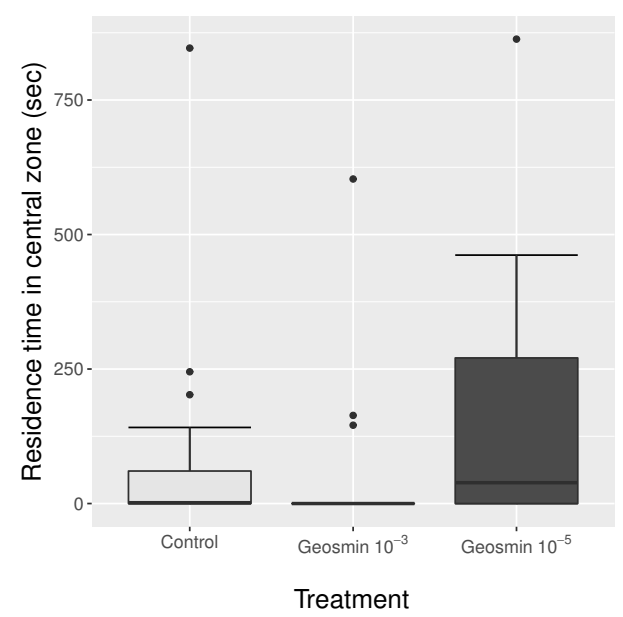

(b)

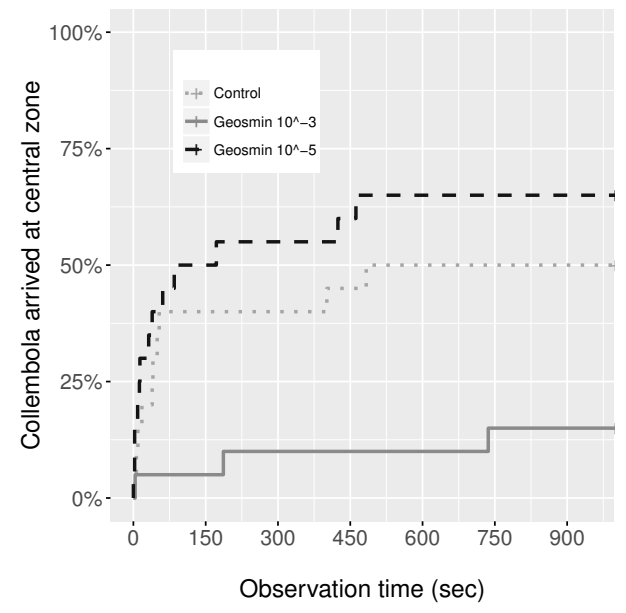

Figure 4.6: F. candida (a) 'residence time in the central zone' and (b) Kaplan Meier curves for the 'first arrival at the central zone' in response to the P. expansum characteristic compound geosmin (concentrations $10^{-3}$ and $10^{-5}$ ) and solvent controls.

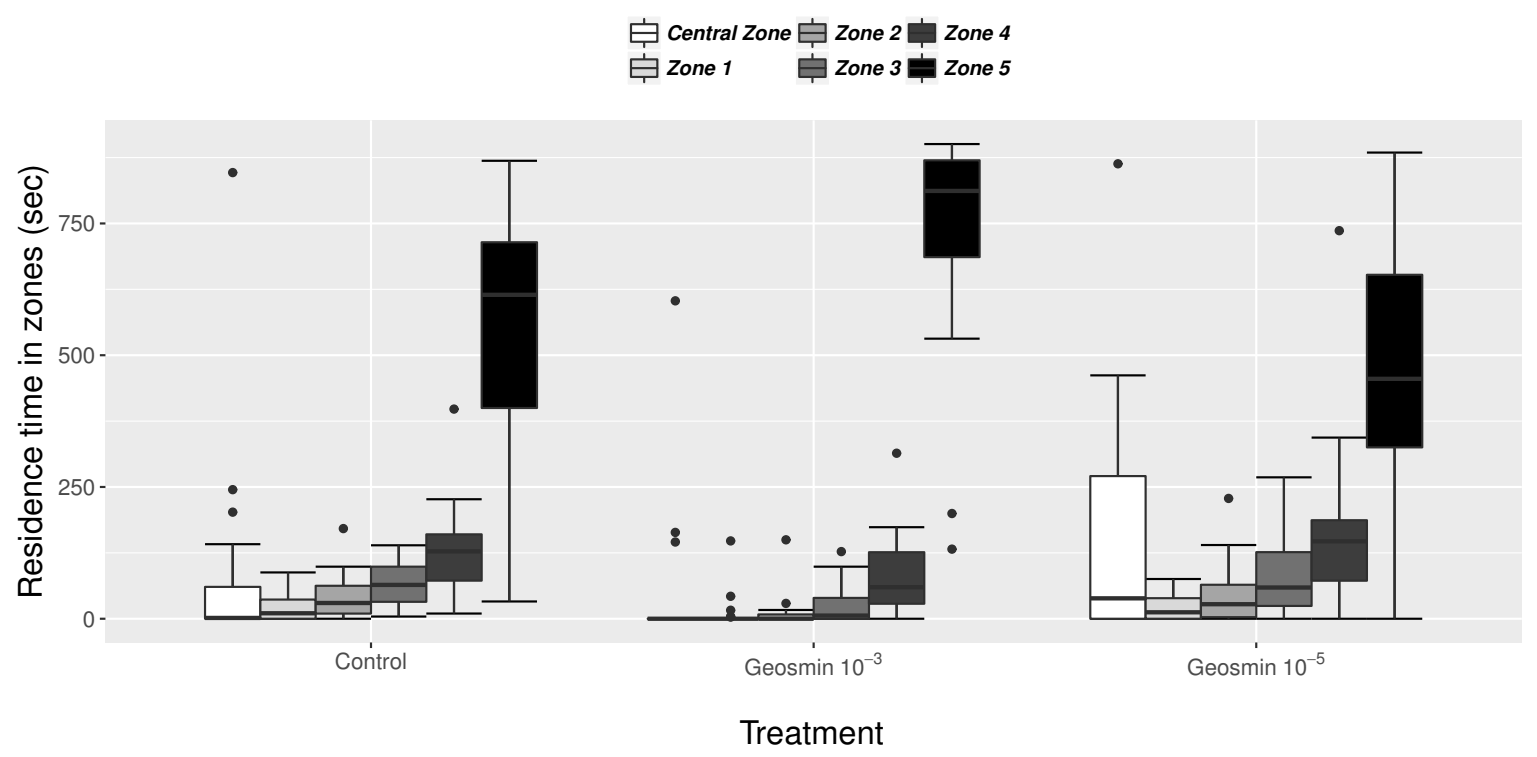

Figure 4.7: 'Distribution of residence time' over predefined zones in response to the P. expansum characteristic compound geosmin (concentrations $10^{-3}$ and $10^{-5}$ ) and solvent controls. 


\subsubsection{CONTACT BEHAVIOUR OF F. candida}

\section{EFFECT OF FUNGAL SPECIES}

A significant global effect of fungal species on the contact behaviour of $F$. candida was found with respect to the 'latency to the first contact' (Cox regression, likelihood ratio test, $\tilde{\chi}^{2}=21.10$, $\mathrm{df}=6, p=0.002)$, the 'duration of the first contact' (Cox regression, likelihood ratio test, $\left.\tilde{\chi}^{2}=13.38, \mathrm{df}=6, p=0.037\right)$, and the 'contact time' (Kruskal-Wallis test, $\tilde{\chi}^{2}=32.94, \mathrm{df}=6, p<0.001$ ). Pairwise comparisons against the control treatment revealed that Collembola contact tendencies ('latency to the first contact') were about 2.6 times higher in the presence of M. pulcherrima and T. dulcitum yeast fungal colonies (Table 4.11, Figure 4.8a). In line with this, Collembola spent a significantly higher percentage of the observation time in contact with T. dulcitum colonies compared to MEA controls (Table 4.12, Figure 4.9). Furthermore, the tendency to leave a T. dulcitum colony after having the first contact was less than half as high as the tendency to leave a control patch, viz. the tendency to stay in further contact with a T. dulcitum colony was considerably higher (Figure 4.8a).

The 'latency to the first feeding event' was significantly affected by the fungal treatment (Cox regression, likelihood ratio test, $\tilde{\chi}^{2}=15.31, \mathrm{df}=6, p=0.018$ ), but in general the feeding activity was low. The highest number of feeding events was observed in the presence of T. dulcitum; 9 out of 20 Collembola fed on T. dulcitum colonies. Only one individual was observed to feed on colonies of filamentous fungi P. expansum and T. harzianum, respectively (Figure 4.8b), with a negligible percentage of the observation time spent with feeding. However, as comparisons of feeding tendencies against the control were not statistically significant (Table 4.11) results only represent trends towards a higher feeding tendency in the presence of T. dulcitum and lower feeding tendencies in response to P. expansum and T. harzianum.

Due to the low number of feeding events in the presence of P. expansum and T. harzianum, an appropriate statistical analysis of the variables 'first feeding duration' (tendency to interrupt feeding), 'time feeding', and 'patch contact frequency prior feeding' was not possible. The corresponding raw data table is included in the appendix (Table A.4.4). 


\section{CHAPTER 4}

VOLATILE-MEDIATED FORAGING RESPONSES TO YEASTS AND FILAMENTOUS FUNGI CORRELATE WITH FUNGIVORE GROWTH AND REPRODUCTION

Table 4.11: Contact phase: Cox regression test statistic for the time-dependent variable 'latency to the first contact' (contact tendency), 'duration of the first contact' (departure tendency), and 'latency to the first feeding event' in response to fungal species. $\exp (\operatorname{coe} f)^{(*)}$ gives the risk of the respective event in comparison to the MEA control group.

\begin{tabular}{|c|c|c|c|c|c|c|c|}
\hline Species & Behavioural variable & $n$ & Events & $Z$ & $\exp (\text { coe } f)^{(*)}$ & $P$-value & $(* *)$ \\
\hline MEA control & First contact & 20 & 12 & & & & \\
\hline A. nidulans & First contact & 20 & 14 & 1.02 & 1.49 & 0.308 & \\
\hline T. harzianum & First contact & 20 & 11 & -0.59 & 0.78 & 0.553 & \\
\hline P. expansum & First contact & 20 & 11 & -0.50 & 0.81 & 0.621 & \\
\hline C. terricola & First contact & 20 & 15 & 1.16 & 1.57 & 0.248 & \\
\hline M. pulcherrima & First contact & 20 & 17 & 2.54 & 2.62 & 0.011 & $\Delta$ \\
\hline T. dulcitum & First contact & 20 & 18 & 2.60 & 2.66 & 0.009 & $\Delta$ \\
\hline MEA control & First contact duration & 12 & 12 & & & & \\
\hline A. nidulans & First contact duration & 14 & 12 & -1.49 & 0.54 & 0.136 & \\
\hline T. harzianum & First contact duration & 11 & 11 & 0.23 & 1.10 & 0.824 & \\
\hline P. expansum & First contact duration & 11 & 11 & 1.03 & 1.55 & 0.305 & \\
\hline C. terricola & First contact duration & 15 & 15 & -1.26 & 0.61 & 0.207 & \\
\hline M. pulcherrima & First contact duration & 17 & 16 & -0.94 & 0.70 & 0.348 & \\
\hline T. dulcitum & First contact duration & 18 & 17 & -2.17 & 0.44 & 0.030 & $\nabla$ \\
\hline MEA control & First feeding & 20 & 4 & & & & \\
\hline A. nidulans & First feeding & 20 & 6 & 0.62 & 1.49 & 0.534 & \\
\hline T. harzianum & First feeding & 20 & 1 & -1.36 & 0.22 & 0.174 & \\
\hline P. expansum & First feeding & 20 & 1 & -1.34 & 0.22 & 0.182 & \\
\hline C. terricola & First feeding & 20 & 4 & -0.004 & 1.00 & 0.997 & \\
\hline M. pulcherrima & First feeding & 20 & 6 & 0.62 & 1.49 & 0.537 & \\
\hline T. dulcitum & First feeding & 20 & 9 & 1.54 & 2.53 & 0.174 & \\
\hline
\end{tabular}

(*) Ratio of hazard rates between two groups. With respect to the latency to the first contact and feeding event a hazard ratio greater than 1 indicates higher contact and/or feeding tendency in a treatment group relative to the control, and a value smaller than 1 lower contact and/or feeding tendency, respectively. Regarding the 'duration of the first contact' a value smaller than 1 indicates higher tendency for remaining (i.e. lower departure tendency) in contact with the respective fungal source relative to the control group.

${ }^{(* *)}$ Compared to the control group $\nabla$ indicates a significant decrease and $\mathbf{\Delta}$ a significant increase in the respective variable.

Table 4.12: Contact phase: test statistic of pairwise comparisons using Dunn's test for multiple comparisons of means with respect to the 'contact time' in response to fungal species. Effect size is represented by Cohen's d, with $95 \%$ confidence interval.

\begin{tabular}{ll|ccc|cc}
\hline Behavioural variable & Comparison & $N$ & $Z$ & Effect size $($ CI $)$ & $P$-value & $(* *)$ \\
\hline Contact time & Control - A. nidulans & 40 & 2.03 & $0.56(-0.09,1.21)$ & 0.084 \\
Contact time & Control - T. harzianum & 40 & 0.04 & $-0.55(-1.20,0.10)$ & 0.819 \\
Contact time & Control - P. expansum & 40 & 0.41 & $-0.46(-1.11,0.19)$ & 0.969 \\
Contact time & Control - C. terricola & 40 & 1.91 & $0.31(-0.33,0.96)$ & 0.084 \\
Contact time & Control - M. pulcherrima & 40 & 2.21 & $0.35(-0.30,0.99)$ & 0.081 & \\
Contact time & Control - T. dulcitum & 40 & 4.20 & $0.94(0.27,1.62)$ & $<\mathbf{0 . 0 0 1}$ & $\Delta$ \\
\hline
\end{tabular}

(*) Compared to the control group $\boldsymbol{\Delta}$ indicates a significant increase in the respective behavioural variable. 
(a)

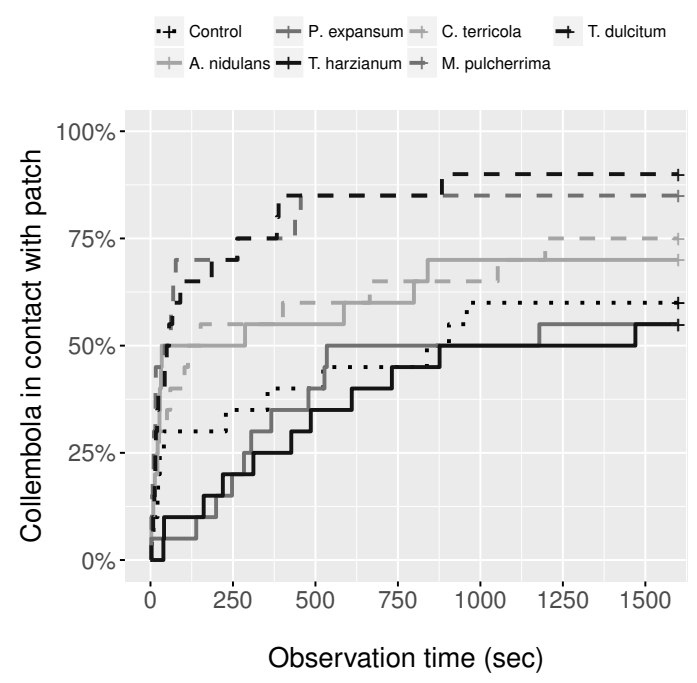

(b)

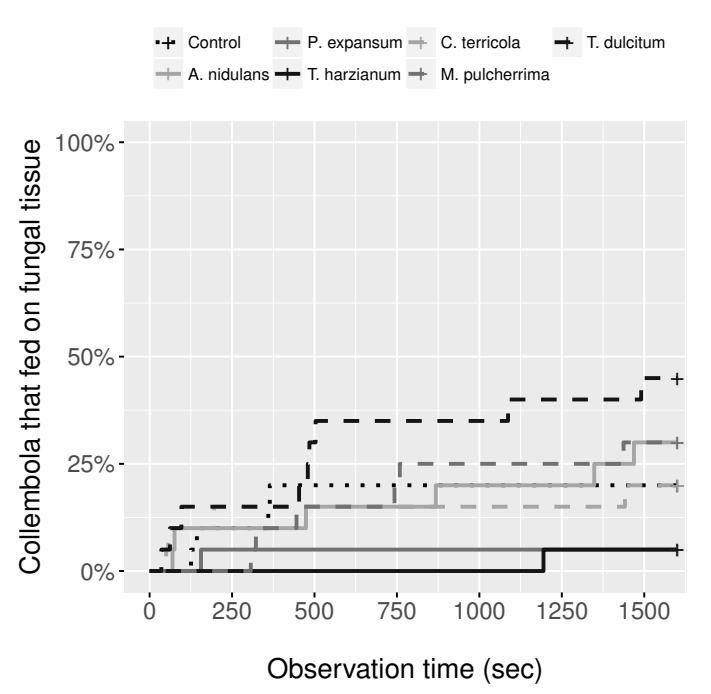

Figure 4.8: Contact phase: Kaplan-Meier curves for F. candida (a) 'latency to the first colony contact' (contact tendency) and (b) 'latency to the first feeding event' (feeding tendency) in response to colonies of filamentous fungi, yeasts, and MEA controls within an observation period of $\sim 25$ minutes.

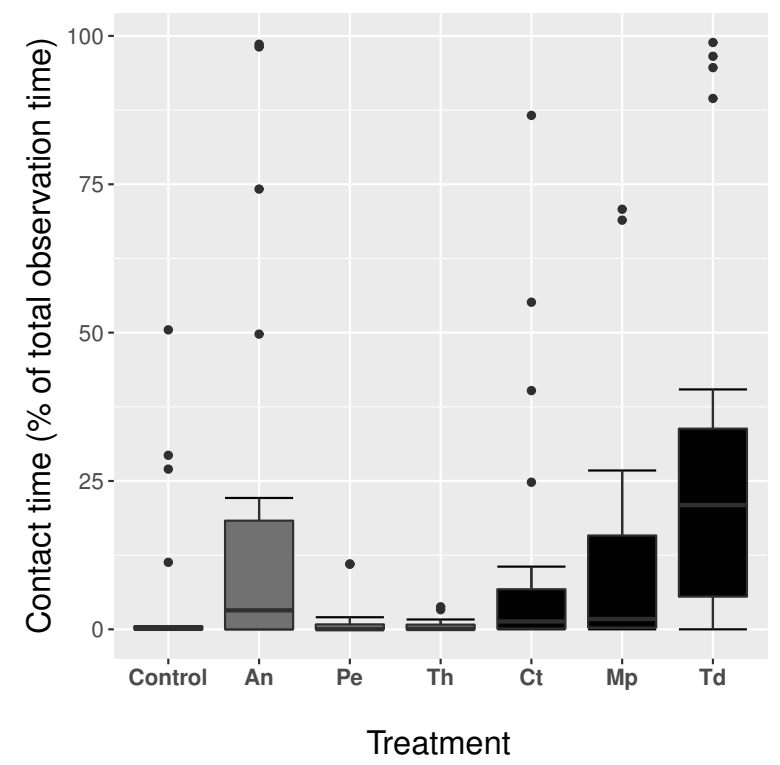

Figure 4.9: Contact phase: 'contact time' of F. candida in response to colonies of filamentous fungi, yeasts, and MEA controls. 


\section{FILAMENTOUS FUNGI VS. YEASTS}

The comparison between fungal life forms revealed that the tendency to get in contact with yeast colonies was 2.24 times higher and the tendency to start feeding on yeasts was 2.68 times higher than the tendency to get in contact with and feed on filamentous fungi Table 4.13, Figure 4.10). The proportion of the observation time Collembola stayed in contact with a yeast colony was also significantly higher compared to filamentous fungi Table 4.13. Figure 4.11). No significant effect of the fungal life form was found with respect to the departure tendency ('duration of the first contact').

Table 4.13: Contact phase: test statistic for 'latency to the first contact' (contact tendency), 'duration of the first contact' (departure tendency), 'latency to the first feeding event' (feeding tendency) (Cox regression), and 'contact time' (Wilcoxon test) in response to fungal life forms (yeasts and filamentous fungi; pooled data). For Cox regression models $\tilde{\chi}^{2}$ values, and for Wilcoxon tests the $Z$-score is given. Effect size is represented by the hazard ratio $\left(\exp (\text { coef })^{(*)}\right)$ and Cohen's $d$, with 95\% confidence interval.

\begin{tabular}{l|ccccc|c}
\hline Behavioural variable & $N$ & Events & $D f$ & $\tilde{\chi}^{2} / Z$ & Effect size $($ CI $)$ & $P-$ value \\
\hline First contact & 120 & 86 & 1 & 13.56 & 2.24 & $<\mathbf{0 . 0 0 1}$ \\
Duration first contact & 86 & 82 & 1 & 3.22 & 0.66 & 0.073 \\
First feeding & 120 & 27 & 1 & 6.05 & 2.68 & $\mathbf{0 . 0 1 4}$ \\
\hline Contact time & 120 & & 1 & -3.86 & $0.44(0.08,0.81)$ & $<0.001$ \\
\hline
\end{tabular}

Given effect sizes relate to the yeast group. With respect to the latency to the first contact and feeding event a hazard ratio greater than 1 indicates higher contact and/or feeding tendency in the yeast group, and a value smaller than 1 lower contact and/or feeding tendency, respectively. Regarding the duration of the first visit a value smaller than 1 indicates higher tendency for remaining (i.e. lower departure tendency) in contact with yeasts.

(a)

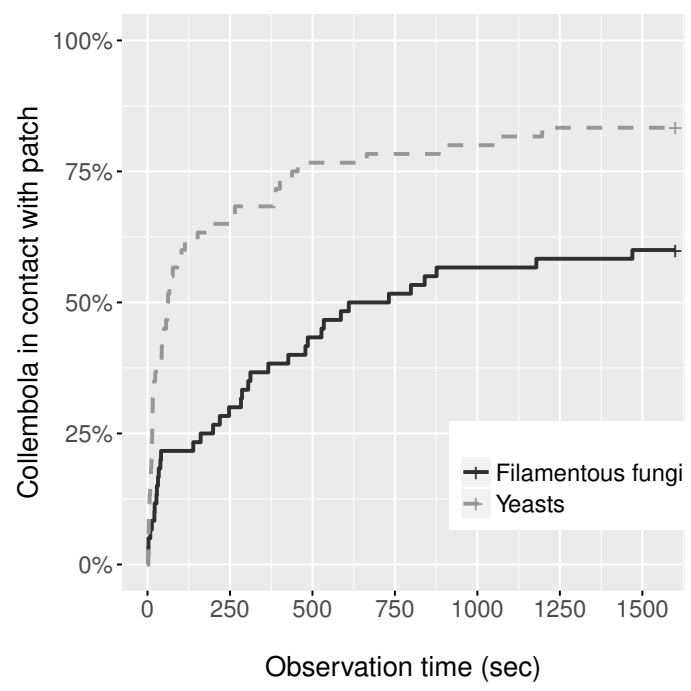

(b)

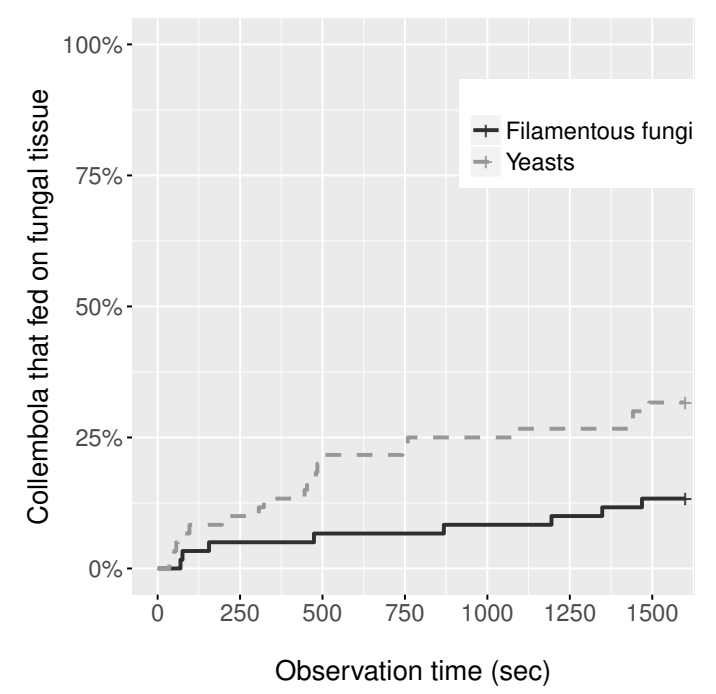

Figure 4.10: Contact phase: Kaplan-Meier curves for F. candida (a) 'latency to the first colony contact' (contact tendency) and (b) 'latency to the first feeding event' (feeding tendency) in response to fungal life forms within an observation period of $\sim 25$ minutes. 


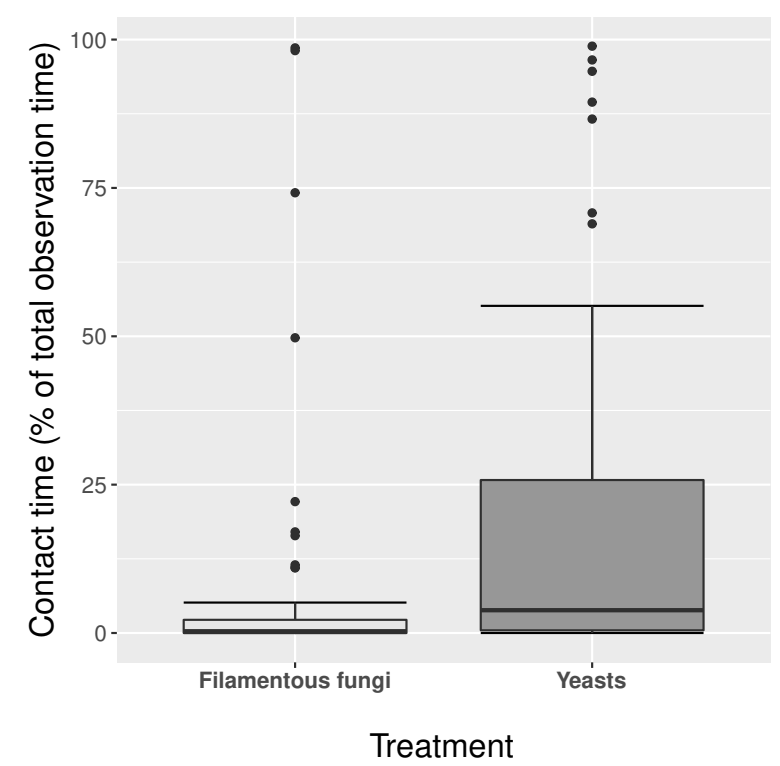

Figure 4.11: Contact phase: 'contact time' of F. candida in response to fungal life forms.

\section{UNWOUNDED VS. WOUNDED COLONIES OF FILAMENTOUS FUNGI}

Collembola contact behaviour in response to fungal tissue wounding was analysed with respect to filamentous fungi $A$. nidulans, P. expansum, and T. harzianum. No significant effects of wounding on behavioural variables were found (Table 4.14).

Table 4.14: Contact phase: test statistic for 'latency to the first contact' (contact tendency), 'duration of the first contact' (departure tendency), 'latency to the first feeding event' (feeding tendency) (Cox regression), and 'contact time' (Wilcoxon test) in response to unwounded and wounded fungal colonies (pooled data). For Cox regression models $\tilde{\chi}^{2}$ values, and for Wilcoxon tests the $Z$-score is given. Effect size is represented by the hazard ratio $\left(\exp (\text { coef })^{(*)}\right)$ and Cohen's d, with $95 \%$ confidence interval.

\begin{tabular}{l|ccccc|c}
\hline Behavioural variable & $N$ & Events & $D f$ & $\tilde{\chi}^{2} / Z$ & Effect size $(C I)$ & $P-$ value \\
\hline First contact & 120 & 79 & 1 & 1.06 & 1.26 & 0.303 \\
Duration first contact & 79 & 77 & 1 & 0.06 & 1.06 & 0.810 \\
First feeding & 120 & 17 & 1 & 0.07 & 1.14 & 0.791 \\
\hline Contact time & 120 & & 1 & -1.16 & $-0.12(-0.48,0.24)$ & 0.248 \\
\hline
\end{tabular}

Given effect sizes relate to the wounding treatment group. With respect to the latency to the first contact and feeding event a hazard ratio greater than 1 indicates higher contact and/or feeding tendency in the wounding group, and a value smaller than 1 lower contact and/or feeding tendency, respectively. Regarding the duration of the first visit a value smaller than 1 indicates higher tendency for remaining (i.e. lower departure tendency) in contact with wounded colonies. 


\subsubsection{EFFECT OF DIFFERENT FUNGAL DIETS ON COLLEMBOLA FITNESS}

Reproduction (number of eggs) (Hurdle negative binomial regression, Wald test, $\tilde{\chi}^{2}=160.44$, $\mathrm{df}=8, p<0.001$ ) and growth (change in body length) (Gamma regression, likelihood ratio test, $\left.\tilde{\chi}^{2}=195.72, \mathrm{df}=7, p<0.001\right)$ of $F$. candida Collembola were significantly affected by the fungal diet and a strong correlation was found between these fitness parameters $(\mathrm{r}=0.71$, 95\% CI: 0.60-0.79, $\mathrm{t}=10.72, \mathrm{df}=115, p<0.001)$. As many zeros were present in the egg data set a hurdle model was applied and revealed that the fungal diet had a significant effect on the number of eggs, but not on the zero count part $\left(\tilde{\chi}^{2}=2.71, p=0.100\right)$, however, the parameter growth had a strong effect on zero egg counts $(z=4.56, p<0.001)$. That means that the probability for laying no eggs was highest for those individuals that had low or no increase in growth, which is true for both control treatments, water agar and MEA, where only $37.5 \%$ and $64.7 \%$ of $F$. candida individuals, respectively, laid eggs, and also for the filamentous fungus P. expansum, where only $33.3 \%$ of individuals laid eggs (Figure 4.13a). In the presence of yeasts C. terricola, M. pulcherrima, and T. dulcitum, and filamentous fungi A. nidulans and T. harzianum, growth and oviposition was significantly increased compared to the water agar control (Figure 4.13, Table 4.15). Collembola performed best in the presence of the yeast T. dulcitum.

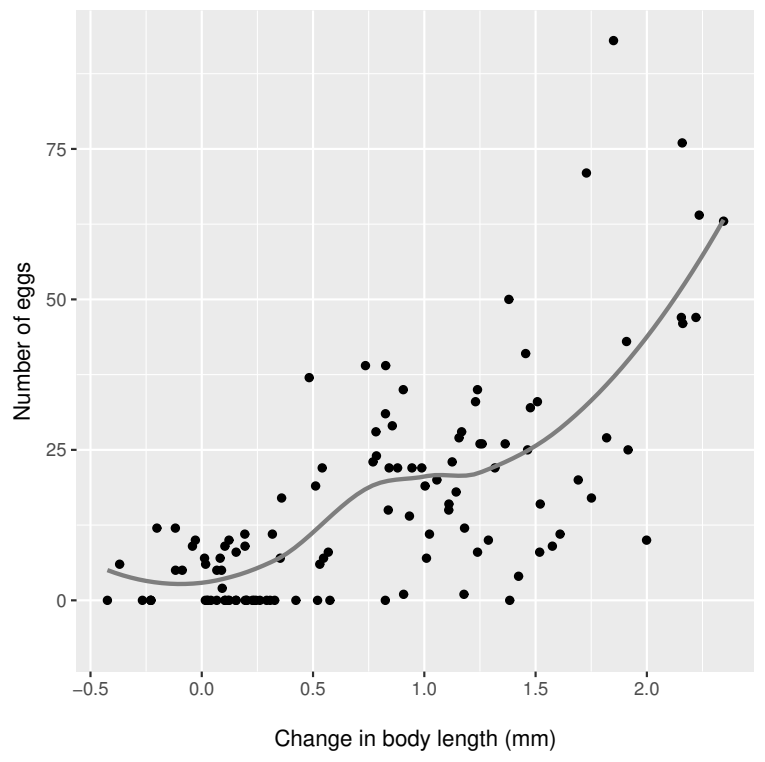

Figure 4.12: Correlation between F. candida fitness parameters reproduction (number of eggs) and growth (change in body length) with lowess line (grey). 
(a)

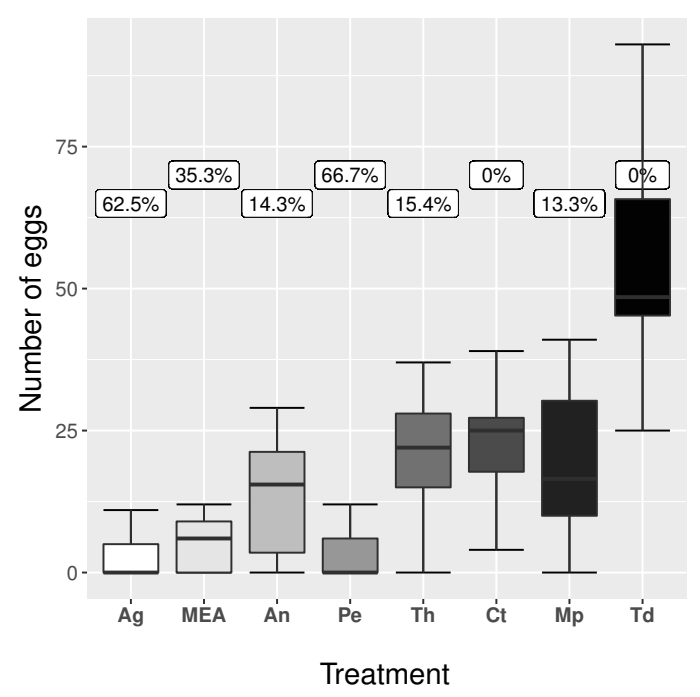

(b)

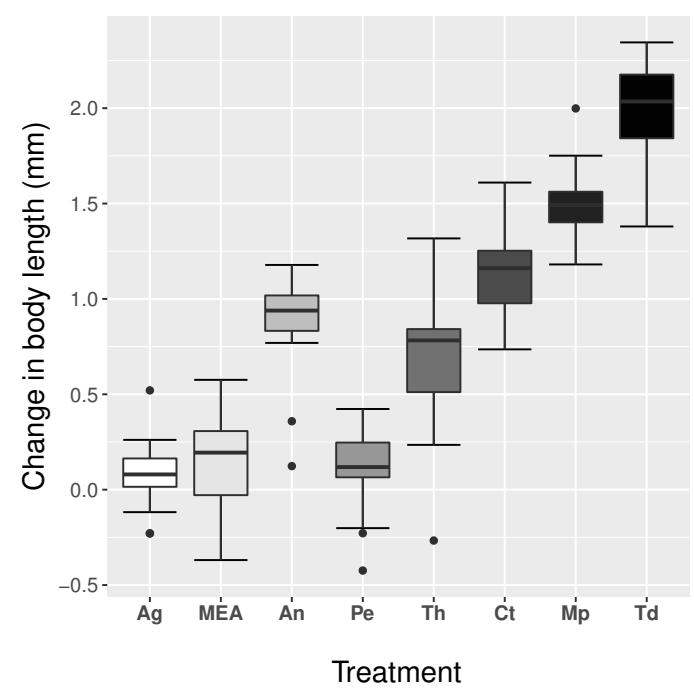

Figure 4.13: F. candida (a) reproduction (number of eggs) and (b) growth (change in body length) in response to filamentous fungi A. nidulans (An), T. harzianum (Th), and P. expansum (Pe), yeasts C. terricola (Ct), M. pulcherrima (Mp), and T. dulcitum (Td), water agar controls (Ag) and MEA controls (MEA). Percent numbers represent the percentage of individuals that laid no eggs. Collembola were exposed to fungal diets for 12 days.

Table 4.15: Collembola fitness: test statistic for parameters 'reproduction' (number of eggs) and 'growth' (change in body length) in response to fungal diets. In case of the Gamma regression (growth) the $t$-value and in Hurdle negative binomial regression (reproduction) the z-value is given in the column 'Statistics'. Effect size is represented by the odds ratio (exp(coef)) with $95 \%$ confidence interval.

\begin{tabular}{|c|c|c|c|c|c|c|}
\hline Dietary treatment & Fitness parameter & $n$ & Statistics & $\exp ($ coef $)(C I)$ & $P$-value & $(*)$ \\
\hline Water agar control & Reproduction & 16 & 8.11 & $6.59(4.18,10.39)$ & $<0.001$ & \\
\hline MEA control & Reproduction & 17 & 0.66 & $1.12(0.69,2.11)$ & 0.509 & \\
\hline A. nidulans & Reproduction & 14 & 3.24 & $2.40(1.41,4.08)$ & 0.001 & $\Delta$ \\
\hline T. harzianum & Reproduction & 13 & 4.69 & $3.54(2.09,6.02)$ & $<0.001$ & $\Delta$ \\
\hline P. expansum & Reproduction & 15 & 0.64 & $1.24(0.64,2.39)$ & 0.525 & \\
\hline C. terricola & Reproduction & 16 & 4.80 & $3.46(2.08,5.75)$ & $<0.001$ & $\Delta$ \\
\hline M. pulcherrima & Reproduction & 14 & 4.27 & $3.10(1.85,5.22)$ & $<0.001$ & $\Delta$ \\
\hline T. dulcitum & Reproduction & 12 & 8.02 & $8.24(4.92,13.81)$ & $<0.001$ & $\Delta$ \\
\hline Water agar control & Growth & 16 & 1.70 & $1.08(0.99,1.17)$ & 0.092 & \\
\hline MEA control & Growth & 17 & 1.21 & $1.08(0.96,1.21)$ & 0.230 & \\
\hline A. nidulans & Growth & 14 & 8.74 & $1.73(1.53,1.96)$ & 0.001 & $\Delta$ \\
\hline T. harzianum & Growth & 13 & 6.84 & $1.55(1.37,1.76)$ & $<0.001$ & $\Delta$ \\
\hline P. expansum & Growth & 15 & 0.37 & $1.02(0.91,1.15)$ & 0.716 & \\
\hline C. terricola & Growth & 16 & 11.23 & $1.98(1.76,2.23)$ & $<0.001$ & $\Delta$ \\
\hline M. pulcherrima & Growth & 14 & 13.39 & $2.33(2.06,2.63)$ & $<0.001$ & $\Delta$ \\
\hline T. dulcitum & Growth & 12 & 15.53 & $2.78(2.44,3.16)$ & $<0.001$ & $\Delta$ \\
\hline
\end{tabular}

(*) Relative to the water agar control group $\mathbf{\Delta}$ a significant increase in the respective fitness parameter. 


\subsection{Discussion}

Several studies suggest a significant role of fungal volatiles in influencing the foraging behaviour of Collembola (Auclerc et al. 2010, Bengtsson et al. 1988; 1991; 1994, Hedlund et al. 1995, Sadaka-Laulan et al. 1998, Staaden et al. 2011). However, the relationship between the volatile-mediated foraging behaviour, the acceptance of a fungus as food by Collembola, and its fitness consequences for the animals is still unknown. Therefore, in the present study I tested whether Collembola use fungal-derived volatiles to differentiate between fungi of varying suitability by observing the foraging behaviour and fitness in response to different yeasts (C. terricola, M. pulcherrima, T. dulcitum) and filamentous fungi (A. nidulans, T. harzianum, P. expansum).

Overall, volatile-mediated foraging responses of Collembola were positively correlated with Collembola fitness measures, indicating that fungal volatiles are used as cues by Collembola to detect suitable and unsuitable fungi from a distance. This finding further strengthens the general assumption that the chemical signature of fungi plays an important role in affecting Collembola foraging and food selection (Böllmann et al. 2010, Hedlund et al.|1995, Rohlfs and Churchill 2011, Stötefeld et al. 2012) and suggests that the use of volatile and non-volatile fungal chemical cues as information is crucial for Collembola to optimize their fitness.

In line with expectations, a comparison of volatile-mediated movement patterns and contact behaviour of $F$. candida Collembola in response to fungal groups - yeasts and filamentous fungi (analysis of pooled data) - revealed that Collembola were more strongly attracted and arrested by yeasts. Moreover, yeasts were more accepted as food source than filamentous fungi when direct contact was allowed. However, these results should be considered with caution because behavioural responses to individual yeast and filamentous fungal species strongly differed, indicating fungal food-specific foraging in Collembola. When the yeast C. terricola and the filamentous fungus P. expansum, whose volatile bouquets were found to be the most attractive and most deterrent ones respectively, were excluded from the pooled data analysis, the effect of fungal groups on Collembola movement patterns became insignificant. Also when focussing on the number of feeding events in response to filamentous fungi, in contrast to T. harzianum and P. expansum for each of which only one feeding event was observed, $A$. nidulans was consumed by six out of 20 individuals and thus more accepted as food source. In the light of this variability in responses within fungal groups, the following discussion will mainly be limited to the effect of individual fungal species. 


\subsubsection{COLLEMBOLA RESPONSES TO FILAMENTOUS FUNGI}

One of the most striking findings to emerge from behavioural observations and the fitness assay is that, among the other tested fungi, exclusively the volatile bouquet of the filamentous fungus $P$. expansum deterred the animals. In line with this Collembola rejected P. expansum as food source and had the lowest growth and reproduction when this fungus was offered as single diet. This strongly suggests that $P$. expansum characteristic volatile and/or non-volatile compounds function as deterrents and reduce the suitability of this fungus as food source. Among several terpenoid compounds that distinguish the volatile profile of P. expansum from those of the other tested fungi, the compound geosmin (trans1,10-di-methyl-trans-9-decalol) was tested on affecting Collembola movement patterns and found to be, at least to some extent, responsible for the deterrent effect. This finding is in line with Stensmyr et al. (2012) who demonstrated that geosmin reduced attraction of fruit flies to vinegar. Another Penicillium species, which is also known to produce the terpenoid geosmin (Siddique 2012), was tested by Sadaka-Laulan et al. (1998) and demonstrated to be less attractive than other fungi. A comparable deterrent effect of other P. expansum-derived volatiles, styrene and 3-methylanisole, was also observed in pine weevils Hylobius abietis (Azeem et al. 2013), suggesting that other compounds could also be involved in affecting the foraging behaviour of Collembola. Preference tests also revealed that P. expansum was less attractive and accepted as food source compared to other fungi (Heděnec et al. 2013) which further supports the assumption that P. expansum is unsuited as food source for Collembola. The rejection of P. expansum as food source may also be related to the presence of mycotoxins, e.g. patulin and citrinin (Bennett et al. 2003), however, direct evidence for pathogenic effects of P. expansum characteristic mycotoxins on arthropods is still missing. In agreement with previous studies that attribute a significant role to fungal secondary metabolites as defence against fungivorous animals (e.g. Böllmann et al. 2010, Caballero Ortiz et al. 2013, Stötefeld et al. 2012), I suggest that the emission of deterrent volatiles, in particular terpenoid compounds such as geosmin, constitute an effective defence mechanism of P. expansum.

Observation of behavioural responses during the contact phase revealed that the filamentous fungus T. harzianum, similar to P. expansum, was the least accepted fungus. Surprisingly, despite the high complexity of its volatile profile and the emission of a range of terpenoid compounds, the volatile bouquet of T. harzianum did not evoke any response, implying that non-volatile metabolites and/or other factors, rather than volatiles, may have served as cues for Collembola to assess the suitability of this fungus. While acceptance was 
low within the observation time of 25 minutes (contact behaviour), when T. harzianum was given as single diet for several days, Collembola growth and reproduction was positively affected. This finding indicates that the initial rejection turns into acceptance when Collembola are exposed to T. harzianum colonies for a longer time period and it can be assumed that T. harzianum is a suitable food source for Collembola. Trichoderma spp. form clumps of sticky spores within a mesh of hyphae which may impede the initial accessibility. In fact, Collembola were incidentally observed to be hindered in their movement on T. harzianum colonies and in some cases Collembola got stuck and were not able to break free. Both filamentous fungi - T. harzianum and A. nidulans - produce a range of toxins (Bräse et al.|2009, Rohlfs and Churchill 2011), are known as plant-, insect-, and fungal pathogens and therefore used as biocontrol agents against different pest species (Benítez et al. 2004, Morath et al. 2012, Omar A. Abdul-Wahid 2012). Despite the toxicity, F. candida Collembola increased growth and laid eggs when these fungi were given as single diets. This finding is in line with previous studies that have demonstrated that both fungi represent palatable food sources for F. candida (Klironomos and Kendrick|1996, Scheu and Simmerling|2004, Staaden et al.|2010). In contrast to F. candida, Pseudosinella alba rejected T. harzianum as food source and ceased their reproduction when this fungus was given as single diet (Ponge and Charpentié 1981). F. candida Collembola are known to have a storage detoxification system; waste products, toxins, and other harmful compounds are stored in the midgut cells of $F$. candida and excreted during moulting (Fountain and Hopkin 2005). This mechanism may enable F. candida Collembola to feed on toxin-producing fungi like T. harzianum. Different Collembola species, however, seem to differ in their detoxification efficiency as suggested by (Staaden et al. 2010), which may explain observed species-specific foraging responses (e.g. Chapter 2 , Hedlund et al. (1995), Staaden et al. (2010)), feeding preferences for, and fitness consequences of fungal food sources (e.g. Larsen et al. 2008, Walsh and Bolger 1990).

\subsubsection{COLLEMBOLA RESPONSES TO WOUND-ACTIVATED CHANGES IN FILAMENTOUS FUNGI}

In the second chapter of this thesis I could show that the activation of oxylipin volatiles caused by fungal tissue wounding increased the acceptance of the saprotrophic fungus C. globosum by F. candida and the oxylipin 3-octanone is suggested to function as phagostimulant since this compound induced test-biting behaviour in two Collembola species 
(F. candida, S. curviseta) (Chapter 2). Wounding of P. expansum, T. harzianum, and A. nidulans also mainly activated the emission of 3-octanone and other oxylipin volatiles, however, increased headspace concentrations of these compounds unexpectedly did not affect volatilemediated searching patterns of F. candida nor acceptance of respective fungi as food source. Possibly, other compounds simultaneously emitted with volatile oxylipins might interfere with the otherwise feeding-stimulating effect of 3-octanone.

\subsubsection{COLlembola RESPONSES TO UNiCELlulaR YeASTS}

Results of behavioural experiments indicate that the volatile bouquet of the yeast $C$. terricola had an arresting effect on Collembola, while the volatile bouquets of the yeasts M. pulcherrima and T. dulcitum attracted Collembola. However, attraction to these yeasts was only observed when Collembola were very close to the fungus (maximum $3 \mathrm{~cm}$ ). This finding agrees with Auclerc et al. (2010) who have demonstrated that food-derived volatiles evoked F. candida Collembola to shift from random to directed movement only from a maximum distance of $2.5 \mathrm{~cm}$. Blind or eye-reduced soil-dwelling (euedaphic, hemiedaphic) invertebrates, including F. candida, can be assumed to rely on the use of volatile cues to locate food from a distance. However, in the complex obstacle rich soil environment the transport of volatiles mainly happens via diffusion and may not be detectable over longer distances. Taking into account the composition of the volatile profiles of these yeasts, results indicate that the presence of the ubiquitous alcoholic compound 3-methyl-1-butanol within an otherwise volatile-poor background may be responsible or at least contribute to the attractiveness of the yeasts. As proposed by Rotheray et al. (2009), physiological characteristics may affect the accessibility and consumption of fungi. I suggest that the unicellular nature of yeasts and a less expansive hyphal growth of some filamentous fungi facilitate their consumption by Collembola, however, this hypothesis has to be tested in future experiments.

\subsubsection{CONCLUSION}

In conclusion, the present study clearly demonstrates that Collembola display fungal foodspecific foraging. Volatile-mediated behavioural responses and feeding decisions (acceptance) of Collembola were well reflected in the fitness of the animals, indicating that the use 
of volatile cues by Collembola is important for the detection of suitable and less suitable fungal food sources. Behavioural responses to the terpenoid compound geosmin strongly suggest that the emission of deterrent fungal volatiles represents an effective defence mechanism against fungivory. Since fungal volatile profiles and behavioural responses of Collembola are highly variable, it is not possible to make general assumptions on the effect of fungal groups (yeasts, filamentous fungi). Moreover, single volatile compound effects, in particular the phagostimulant effect of the wound-activated oxylipin 3-octanone, are supposed to depend on the composition of volatile profiles. 


\section{REFERENCES}

Anagnostou C, Dorsch M, and Rohlfs M, 2010. Influence of dietary yeasts on Drosophila melanogaster life-history traits. Entomologia Experimentalis et Applicata, 136(1):1-11. ISSN 00138703. doi:10.1111/j.1570-7458.2010.00997.x.

Auclerc A, Libourel PA, Salmon S, Bels V, and Ponge JF, 2010. Assessment of movement patterns in Folsomia candida (Hexapoda: Collembola) in the presence of food. Soil Biology and Biochemistry, 42(4):657-659. ISSN 00380717. doi:10.1016/j.soilbio.2009.12.012.

Azeem M, Rajarao GK, Nordenhem H, Nordlander G, and Borg-Karlson AK, 2013. Penicillium expansum volatiles reduce pine weevil attraction to host plants. Journal of Chemical Ecology, 39(1):120-128. ISSN 1573-1561. doi:10.1007/s10886-012-0232-5.

Bardgett RD, Whittaker JB, and Frankland JC, 1993. The diet and food preferences of Onychiurus procampatus (Collembola) from upland grassland soils. Biology and Fertility of Soils, 16:296-298. doi:10.1007/BF00369308.

Becher PG, Bengtsson M, Hansson BS, and Witzgall P, 2010. Flying the fly: long-range flight behavior of Drosophila melanogaster to attractive odors. Journal of Chemical Ecology, 36(6):599-607. doi:10.1007/s10886-010-9794-2.

Bengtsson G, Erlandsson A, and Rundgren S, 1988. Fungal odour attracts soil Collembola. Soil Biology and Biochemistry, 20(1):25-30. ISSN 00380717. doi:10.1016/0038-0717(88) 90122-8.

Bengtsson G, Hedlund K, and Rundgren S, 1991. Selective odor perception in the soil Collembola Onychiurus armatus. Journal of Chemical Ecology, 17(11):2113-2125. doi: 10.1007/BF00987995.

Bengtsson G, Hedlund K, and Rundgren S, 1994. Food- and density-dependent dispersal: evidence from a soil collembolan. Journal of Animal Ecology, 63(3):513-520. doi:10.2307/ 5218.

Benítez T, Rincón AM, Limón MC, and Codón AC, 2004. Biocontrol mechanisms of Trichoderma strains. International Microbiology, 7(4):249-260. ISSN 11396709.

Bennett JW, Klich M, and Mycotoxins M, 2003. Mycotoxins. Clinical Microbiology Reviews, 16(3):497-516. ISSN 0893-8512. doi:10.1128/CMR.16.3.497.

Blackwell M, 2017. Made for each other: ascomycete yeasts and insects. The Fungal Kingdom, pages 945-962. doi:10.1128/microbiolspec.FUNK-0081-2016.

Böllmann J, Elmer M, Wöllecke J, Raidl S, and Hüttl RF, 2010. Defensive strategies of soil fungi to prevent grazing by Folsomia candida (Collembola). Pedobiologia, 53(2):107-114. ISSN 00314056. doi:10.1016/j.pedobi.2009.06.003.

Bräse S, Encinas A, Keck J, and Nising CF, 2009. Chemistry and biology of mycotoxins and related fungal metabolites. Chemical Reviews, 109(9):3903-3990. ISSN 00092665. doi: $10.1021 /$ cr050001f. 
Brodhun F and Feussner I, 2011. Oxylipins in fungi. FEBS Journal, 278(7):1047-1063. ISSN 1742464X. doi:10.1111/j.1742-4658.2011.08027.x.

Byzov BA, Nguyen Thanh V, and Babjeva IP, 1993. Interrelationships between yeasts and soil diplopods. Soil Biology and Biochemistry, 25(8):1119-1126. ISSN 00380717. doi:10.1016/ 0038-0717(93)90160-D.

Caballero Ortiz S, Trienens M, and Rohlfs M, 2013. Induced fungal resistance to insect grazing: reciprocal fitness consequences and fungal gene expression in the DrosophilaAspergillus model system. PloS ONE, 8(8):e74951. ISSN 1932-6203. doi:10.1371/journal. pone.0074951.

Combet E, Henderson J, Eastwood DC, and Burton KS, 2009. Influence of sporophore development, damage, storage, and tissue specificity on the enzymic formation of volatiles in mushrooms (Agaricus bisporus). Journal of Agricultural and Food Chemistry, 57(9):3709-3717. ISSN 00218561. doi:10.1021/jf8036209.

Crowther TW, Stanton DWG, Thomas SM, A'Bear AD, Hiscox J, Jones TH, Vorísková J, Baldrian P, and Boddy L, 2013. Top-down control of soil fungal community composition by a globally distributed keystone consumer. Ecology, 94(11):2518-2528. doi: 10.1890/13-0197.1.

Davis TS, 2015. The ecology of yeasts in the bark beetle holobiont: a century of research revisited. Microbial Ecology, 69(4):723-732. ISSN 00953628. doi:10.1007/s00248-014-0479-1.

Davis TS, Crippen TL, Hofstetter RW, and Tomberlin JK, 2013. Microbial volatile emissions as insect semiochemicals. Journal of Chemical Ecology, 39(7):840-59. ISSN 1573-1561. doi: 10.1007/s10886-013-0306-Z.

Dethier V, Barton Browne L, and Smith C, 1960. The designation of chemicals in terms of the responses they elicit from insects. Journal of Economic Entomology, 53:134-136. doi: 10.1093/jee/53.1.134.

Döll K, Chatterjee S, Scheu S, Karlovsky P, and Rohlfs M, 2013. Fungal metabolic plasticity and sexual development mediate induced resistance to arthropod fungivory. Proceedings of the Royal Scociety B, 280(1771):20131219. ISSN 1471-2954. doi:10.1098/rspb.2013.1219.

Dunn OJ, 1964. Multiple comparisons using rank sums. Technometrics, 6(3):241-252.

Esteve-Zarzoso B, Belloch C, Uruburu F, and Querol A, 1999. Identification of yeasts by RFLP analysis of the 5.8S rRNA gene and the two ribosomal internal transcribed spacers. International Journal of Systematic Bacteriology, 49(1):329-337. ISSN 0020-7713. doi:10.1099/ 00207713-49-1-329.

Fäldt J, Jonsell M, Nordlander G, and Borg-Karlson AK, 1999. Volatiles of bracket fungi Fomitopsis pinicola and Fomes fomentarius and their functions as insect attractants. Journal of Chemical Ecology, 25(3):567-590. doi:10.1023/A:1020958005023.

Fountain MT and Hopkin SP, 2005. Folsomia candida (Collembola): a "standard" soil arthropod. Annual Review of Entomology, 50(1):201-222. ISSN 0066-4170. doi:10.1146/annurev. ento.50.071803.130331.

Gams W, 2007. Biodiversity of soil-inhabiting fungi. Biodiversity and Conservation, 16(1):6972. ISSN 09603115. doi:10.1007/s10531-006-9121-y. 
Gershenzon J and Dudareva N, 2007. The function of terpene natural products in the natural world. Nature Chemical Biology, 3(7):408-14. ISSN 1552-4450. doi:10.1038/nchembio.2007. 5 .

Harrington TC, 2005. Ecology and evolution of mycophagous bark beetles and their fungal partners. In F Vega and M Blackwell, editors, Insect-fungal associations: ecology and evolution, pages 257-291. Oxford University Press. ISBN 0-19-516652-3.

Heděnec P, Radochová P, Nováková A, Kaneda S, and Frouz J, 2013. Grazing preference and utilization of soil fungi by Folsomia candida (Isotomidae: Collembola). European Journal of Soil Biology, 55:66-70. ISSN 11645563. doi:10.1016/j.ejsobi.2012.12.005.

Hedlund K, Bengtsson G, and Rundgren S, 1995. Fungal odour discrimination in two sympatric species of fungivorous collembolans. Functional Ecology, 9(6):869-875. ISSN 02698463. doi: $10.2307 / 2389984$.

Holighaus G and Rohlfs M, 2018. Volatile and non-volatile fungal oxylipins in fungus invertebrate interactions. Fungal Ecology (in press). doi:10.1016/j.funeco.2018.09.005.

Hopkin S, 1997. The biology of the Collembola (springtails): the most abundant insects in the world. Natural History Museum, London. ISBN 0198540841.

Jørgensen HB, Hedlund K, and Axelsen JA, 2008. Life-history traits of soil collembolans in relation to food quality. Applied Soil Ecology, 38(2):146-151. ISSN 09291393. doi:10.1016/j. apsoil.2007.10.003.

Kjoller A and Struwe S, 1982. Microfungi in ecosystems: fungal occurrence and activity in litter and soil. Nordic Society Oikos, 39(3):391-422. ISSN 0030-1299. doi:10.2307/3544690.

Klironomos AJN, Bednarczuk EM, and Neville J, 2008. Reproductive significance of feeding on saprobic and arbuscular mycorrhizal fungi by the collembolan, Folsomia candida. Functional Ecology, 13(6):756-761. doi:10.1046/j.1365-2435.1999.00379.x.

Klironomos JN and Kendrick WB, 1996. Palatability of microfungi to soil arthropods in relation to the functioning of arbuscular mycorrhizae. Biology and Fertility of Soils, 21(12):43-52. ISSN 0178-2762. doi:10.1007/BF00335992.

Larsen J, Johansen A, Erik Larsen S, Henrik Heckmann L, Jakobsen I, and Henning Krogh $\mathrm{P}, 2008$. Population performance of collembolans feeding on soil fungi from different ecological niches. Soil Biology and Biochemistry, 40(2):360-369. ISSN 00380717. doi:10. 1016/j.soilbio.2007.08.016.

Mahmoud MAA and Buettner A, 2016. Characterisation of aroma-active and off-odour compounds in German rainbow trout (Oncorhynchus mykiss). Part I: Case of aquaculture water from earthen-ponds farming. Food Chemistry, 210(November):623-630. ISSN 18737072. doi:10.1016/j.foodchem.2016.05.030.

Maraun M, Martens H, Migge S, Theenhaus A, and Scheu S, 2003. Adding to 'the enigma of soil animal diversity': fungal feeders and saprophagous soil invertebrates prefer similar food substrates. European Journal of Soil Biology, 39(2):85-95. ISSN 11645563. doi:10.1016/ S1164-5563(03)00006-2. 
Martin JF, Bennett LW, and Fisher TH, 1988a. Musty odor in chronically off-flavored channel catfish: isolation of 2-methylenebornane and 2-methyl-2-bornene. Journal of Agricultural and Food Chemistry, 36(6):1257-1260. ISSN 15205118. doi:10.1021/jf00084a032.

Martin JF, Bennett LW, and Graham WH, 1988b. Off-flavor in the channel catfish (Ictalurus punctatus). Water Science and Technology, 20(8):99-105. doi:10.2166/wst.1988.0230.

Men'ko EV, Chernov II, and Byzov Ba, 2006. Interrelationships between yeast fungi and collembolans in soil. Mikrobiologiia, 75(6):814-822. ISSN 0026-2617. doi:10.1134/ S0026261706060142.

Moore JC, Ingham ER, and Coleman DC, 1987. Inter- and intraspecific feeding selectivity of Folsomia candida (Willem) (Collembola, Isotomidae) on fungi. Biology and Fertility of Soils, 5(1):6-12. ISSN 01782762. doi:10.1007/BF00264338.

Morath SU, Hung R, and Bennett JW, 2012. Fungal volatile organic compounds: a review with emphasis on their biotechnological potential. Fungal Biology Reviews, 26(2-3):73-83. ISSN 17494613. doi:10.1016/j.fbr.2012.07.001.

Noldus LPJJ, 1991. The Observer: a software system for collection and analysis of observational data. Behavior Research Methods, 23(3):415-429. doi:10.3758/BF03203406.

Noldus LPJJ, Spink AJ, and Tegelenbosch RAJ, 2001. EthoVision: a versatile video tracking system for automation of behavioral experiments. Behavior Research Methods, Instruments, $\mathcal{E}$ Computers, 33(3):398-414. ISSN 0743-3808. doi:10.3758/BF03195394.

Omar A Abdul-Wahid, 2012. Evaluation of the insecticidal activity of Fusarium solani and Trichoderma harzianum against cockroaches; Periplaneta americana. African Journal of Microbiology Research, 6(5):1024-1032. doi:10.5897/AJMR-11-1300.

Pawliszyn J, 1997. Solid phase microextraction: theory and practice. Wiley-VCH, Inc, New York.

Ponge JF, 1991. Food resources and diets of soil animals in a small area of Scots pine litter. Geoderma, 49(1-2):33-62. ISSN 00167061. doi:10.1016/0016-7061(91)90090-G.

Ponge JF and Charpentié MJ, 1981. Etude des relations microflore-microfaune: expériences sur Pseudosinella alba (Packard), collembole mycophage. Revue d'Ecologie et de Biologie du Sol, 18(3):291-303. ISSN 0035-1822.

Rohlfs M, 2015. Fungal secondary metabolite dynamics in fungus-grazer interactions: novel insights and unanswered questions. Frontiers in Microbiology, 6(JAN):1-5. ISSN 1664302X. doi:10.3389/fmicb.2014.00788.

Rohlfs M, Albert M, Keller NP, and Kempken F, 2007. Secondary chemicals protect mould from fungivory. Biology Letters, 3:523-525. ISSN 1744-9561. doi:10.1098/rsbl.2007.0338.

Rohlfs M and Churchill ACL, 2011. Fungal secondary metabolites as modulators of interactions with insects and other arthropods. Fungal Genetics and Biology, 48(1):23-34. ISSN 10871845. doi:10.1016/j.fgb.2010.08.008.

Rotheray TD, Boddy L, and Jones TH, 2009. Collembola foraging responses to interacting fungi. Ecological Entomology, 34(1):125-132. ISSN 03076946. doi:10.1111/j.1365-2311.2008. 01050.x. 
Rusek J, 1998. Biodiversity of Collembola and their functional role in the ecosystem. Biodiversity and Conservation, 7(9):1207-1219. ISSN 09603115. doi:10.1023/A:1008887817883.

Sadaka-Laulan N, Ponge JF, Roquebert MF, Bury E, and Boumezzough A, 1998. Feeding preferences of the collembolan Onychiurus sinensis for fungi colonizing holm oak litter (Quercus rotundifolia Lam.). European Journal of Soil Biology, 34(4):179-188. ISSN 11645563. doi:10.1016/S1164-5563(00)86660-1.

Scheu S and Setälä H, 2002. Multitrophic interactions in decomposer food-webs. In T Tscharntke and B Hawkins, editors, Multitrophic level interactions, January, pages 223264. Cambridge University Press. ISBN 9780521791106. doi:10.1017/CBO9780511542190. 010.

Scheu S and Simmerling F, 2004. Growth and reproduction of fungal feeding Collembola as affected by fungal species, melanin and mixed diets. Oecologia, 139(3):347-353. ISSN 00298549. doi:10.1007/s00442-004-1513-7.

Schnürer J, Clarholm M, and Rosswall T, 1985. Microbial biomass and activity in an agricultural soil with different organic matter contents. Soil Biology and Biochemistry, 17(5):611618. ISSN 00380717. doi:10.1016/0038-0717(85)90036-7.

Schoenfeld D, 1980. Chi-squared goodness-of-fit tests for the proportional hazards regression model. Biometrika, 67(1):145-153. doi:10.1093/biomet/67.1.145.

Schoenfeld D, 1982. Partial residuals for the proportional hazards regression-model. Biometrika, 69(1):239-241. ISSN 00063444. doi:Doi10.2307/2335876.

Schoonhoven LM, van Loon JJA, and Dicke M, 2005. Insect-plant biology. Oxford University Press, New York, 2 edition. ISBN 978-0-19-852594-3.

Siddique MH, 2012. Study of the biosynthesis pathway of the geosmin in Penicillium expansum. Ph.D. thesis, University of Toulouse.

Spiteller P, 2008. Chemical defence strategies of higher fungi. Chemistry, 14(30):9100-10. ISSN 0947-6539. doi:10.1002/chem.200800292.

Staaden S, Milcu A, Rohlfs M, and Scheu S, 2010. Fungal toxins affect the fitness and stable isotope fractionation of Collembola. Soil Biology and Biochemistry, 42(10):1766-1773. ISSN 00380717. doi:10.1016/j.soilbio.2010.06.014.

Staaden S, Milcu A, Rohlfs M, and Scheu S, 2011. Olfactory cues associated with fungal grazing intensity and secondary metabolite pathway modulate Collembola foraging behaviour. Soil Biology and Biochemistry, 43(7):1411-1416. ISSN 00380717. doi: 10.1016/j.soilbio.2010.10.002.

Stensmyr MC, Dweck HKM, Farhan A, Ibba I, Strutz A, Mukunda L, Linz J, Grabe V, Steck K, Lavista-Llanos S, Wicher D, Sachse S, Knaden M, Becher PG, Seki Y, and Hansson BS, 2012. A conserved dedicated olfactory circuit for detecting harmful microbes in Drosophila. Cell, 151(6):1345-1357. ISSN 00928674. doi:10.1016/j.cell.2012.09.046.

Stötefeld L, Scheu S, and Rohlfs M, 2012. Fungal chemical defence alters density-dependent foraging behaviour and success in a fungivorous soil arthropod. Ecological Entomology, 37(5):323-329. ISSN 03076946. doi:10.1111/j.1365-2311.2012.01373.x. 
Styczynski MP, Moxley JF, Tong LV, Walther JL, Jensen KL, and Stephanopoulos GN, 2007. Systematic identification of conserved metabolites in GC/MS data for metabolomics and biomarker discovery. Analytica Chimica Acta, 79(3):966-973. doi:10.1021/ac0614846.

Walsh MI and Bolger T, 1990. Effects of diet on the growth and reproduction of some Collembola in laboratory cultures. Pedobiologia, 34(3):161-171. ISSN 0031-4056. doi: 10.1007/s00442-004-1513-7.

Witzgall P, Proffit M, Rozpedowska E, Becher PG, Andreadis S, Coracini M, Lindblom TUT, Ream LJ, Hagman A, Bengtsson M, Kurtzman CP, Piskur J, and Knight A, 2012. "This is not an apple"-yeast mutualism in codling moth. Journal of Chemical Ecology, 38(8):949-957. ISSN 00980331. doi:10.1007/s10886-012-0158-y.

Wurzenberger M and Grosch W, 1983. Bestimmung von 1-Octen-3-ol in Pilzen und Pilzprodukten. Zeitschrift für Lebensmitteluntersuchung und -Forschung A, 25:567-590. doi: 10.1007/BF01089340.

Yurkov AM, Chernov IY, and Tiunov AV, 2008. Influence of Lumbricus terrestris earthworms on the structure of the yeast community of forest litter. Microbiology, 77(1):107-111. ISSN 00262617. doi:10.1007/s11021-008-1015-4.

Zimmer M, 2002. Nutrition in terrestrial isopods (Isopoda: Onisicdea): an evolutionaryecological aprroach. Biological Reviews, 77:455-493. doi:10.1017/S1464793102005912. 


\section{APPENDiX}

Table A.4.1: Analytical response (manually integrated TIC peak area) to authentic geosmin diluted with paraffin at four concentrations (conc) (corresponding calibration plot: Figure A.2.1). The average TIC peak area of geosmin obtained from chromatograms of unwounded and wounded P. expansum colonies is 2312126 $(\log (T I C)=6.34)$.

\begin{tabular}{cccc}
\hline Concentration & TIC peakarea & $\log ($ Concentration $)$ & $\log ($ TIC peakarea $)$ \\
\hline 0.000001 & 67643 & -6 & 4.83 \\
0.00001 & 101382 & -5 & 5.01 \\
0.0001 & 842912 & -4 & 5.93 \\
0.001 & 5494647 & -3 & 6.74 \\
\hline
\end{tabular}

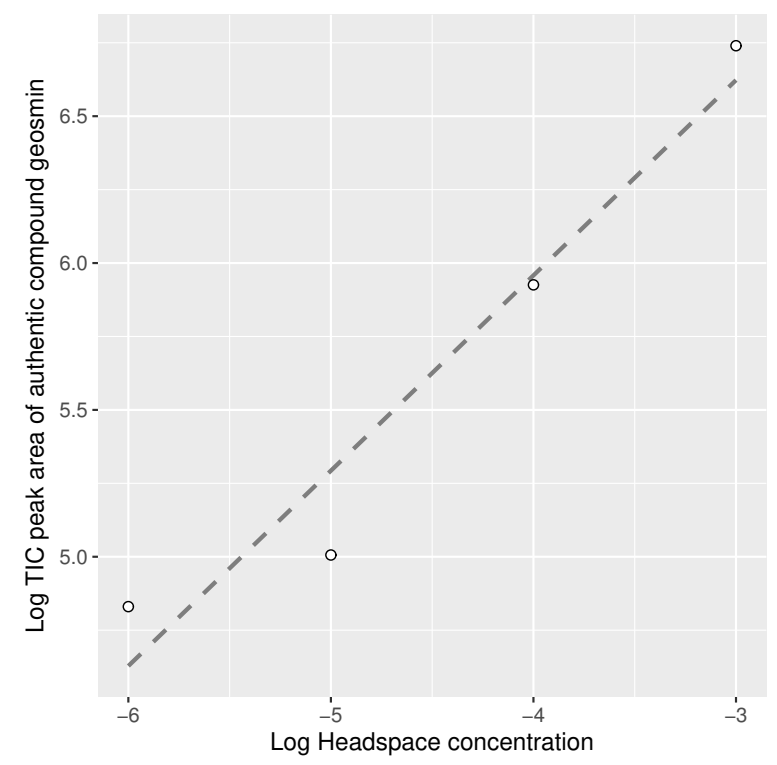

Figure A.4.1: Logarithmic calibration plot with linear trendline (dotted, gray) representing analytical response (TIC peak area) as a function of known analyte concentration for the authentic volatile compound geosmin (adjusted $R^{2}=0.9999$, intercept $=132892$, slope $\left.=5378053261, p=0.004\right)$. The average TIC peak area of geosmin obtained from chromatograms of unwounded and wounded P. expansum colonies is $2312126(\log ($ TIC $)=6.34)$. Respective linear model estimates were used for quantification of the average geosmin headspace concentration in P. expansum colonies (formula: $x=(2312126-5378053261) / 132892 ; \log (x)=-3.61)$. This calculation revealed an average geosmin headspace concentration of $25^{-4}$ (result of $\left.10^{(\log (x))}\right)$ in P. expansum colonies. 


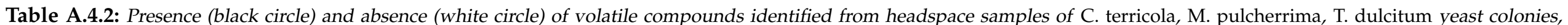

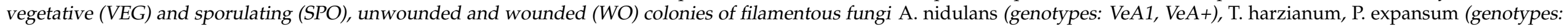
$A, B)$, and fungal-free MEA medium controls. Presence was assumed if a compound was detected in two out of six replicates.

\begin{tabular}{|c|c|c|c|c|c|c|c|c|c|c|c|c|c|c|c|c|c|c|c|c|c|c|c|c|c|c|c|c|c|c|c|}
\hline & & 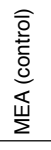 & 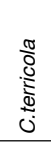 & 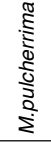 & $\begin{array}{l}\frac{5}{5} \\
\frac{5}{5} \\
\frac{3}{5} \\
\end{array}$ & 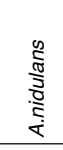 & 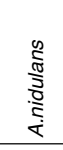 & 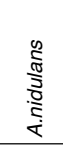 & 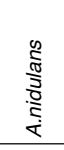 & 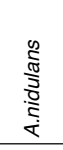 & 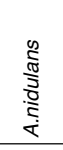 & 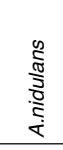 & 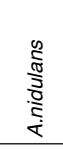 & $\begin{array}{r}5 \\
5 \\
0 \\
0 \\
0 \\
0 \\
0 \\
0 \\
0.0 \\
\end{array}$ & 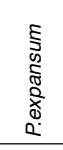 & 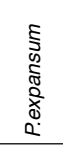 & 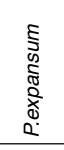 & 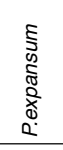 & 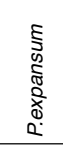 & 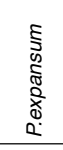 & 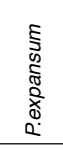 & 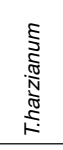 & 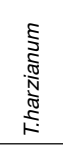 & 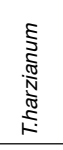 & 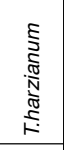 & & & & & & \\
\hline Compound & CAS & & & & & $\begin{array}{l}\text { VeA1 } \\
\text { VEG }\end{array}$ & VeA1 & $\begin{array}{c}\text { VeA1 } \\
\text { WO } \\
\text { VEG }\end{array}$ & $\begin{array}{l}\text { VeA1 } \\
\text { WO } \\
\text { SPO }\end{array}$ & $\mathrm{VeA}+$ & VeAt & $\begin{array}{c}\text { VeAt } \\
\text { WO } \\
\text { VEG }\end{array}$ & $\begin{array}{l}\text { VeAt } \\
\text { WO } \\
\text { SPO }\end{array}$ & VEG & SPO & $\begin{array}{c}\text { A } \\
\text { Wo } \\
\text { VEG }\end{array}$ & $\begin{array}{c}\text { A } \\
\text { wo } \\
\text { SPO }\end{array}$ & VEG & $\begin{array}{c}\text { B } \\
\text { SPO }\end{array}$ & $\begin{array}{c}\text { B } \\
\text { Wo } \\
\text { VEG }\end{array}$ & $\begin{array}{c}\text { B } \\
\text { wo } \\
\text { SPO }\end{array}$ & VEG & SPO & $\begin{array}{l}\text { WO } \\
\text { VEG }\end{array}$ & $\begin{array}{l}\text { wo } \\
\text { SPO }\end{array}$ & Identification * & $\mathrm{RI}_{\mathrm{Tc}}{ }^{1}$ & $\mathrm{RI}_{\mathrm{u}^{2}}$ & $\mathrm{RI}_{\mathrm{AC}}{ }^{3}$ & $\mathrm{RI}_{\mathrm{IE}}{ }^{4}$ & - Reference $\left(\mathrm{RI}_{\mathrm{I}_{\mathrm{L}}}\right.$ \\
\hline \multicolumn{32}{|l|}{ Acetates } \\
\hline 1-octen-3-ol acetate & $2442-10-6$ & $\circ$ & 0 & 0 & 0 & 0 & 0 & • & - & 0 & 0 & - & - & 0 & 0 & 0 & $\circ$ & $\circ$ & 0 & 0 & 0 & 0 & $\circ$ & $\circ$ & 0 & NISTms & 1112 & 1112 & - & - & Benzo et al. (2007) \\
\hline 3-octanol acetate & $4864-61-3$ & $\circ$ & 0 & - & 0 & $\circ$ & 0 & $\circ$ & 0 & $\circ$ & 0 & 0 & $\circ$ & 0 & $\circ$ & 0 & 0 & $\circ$ & 0 & 0 & $\circ$ & 0 & 0 & $\circ$ & $\circ$ & NISTms & 1126 & 1127 & 1126 & - & Andriamaharavo (2014) \\
\hline Ethyl acetate & $141-78-6$ & - & - & - & $\circ$ & - & - & - & - & - & 0 & - & 0 & - & - & - & - & - & - & - & - & - & $\circ$ & - & 0 & NISTms & 626 & 612 & - & - & Madruga \& Mottram (1998) \\
\hline Isoamyl acetate & $123-92-2$ & $\circ$ & $\circ$ & - & $\circ$ & $\circ$ & $\circ$ & $\circ$ & $\circ$ & $\circ$ & $\circ$ & $\circ$ & $\circ$ & 0 & $\circ$ & $\circ$ & 0 & $\circ$ & $\circ$ & $\circ$ & $\circ$ & $\circ$ & $\circ$ & $\circ$ & $\circ$ & NISTms & 887 & 878 & - & - & Moio et al. (2000) \\
\hline Isobutyl acetate & $110-19-0$ & $\circ$ & $\circ$ & • & $\circ$ & $\circ$ & 0 & $\circ$ & 0 & $\circ$ & $\circ$ & $\circ$ & $\circ$ & $\circ$ & 0 & $\circ$ & 0 & $\circ$ & $\circ$ & $\circ$ & 0 & 0 & 0 & $\circ$ & 0 & NISTms & 784 & 788 & - & - & Fang \& Qian (2005) \\
\hline \multicolumn{32}{|l|}{ Alcohols } \\
\hline 1-octen-3-ol & $3391-86-4$ & 0 & $\circ$ & 0 & $\circ$ & - & $\circ$ & - & - & - & 0 & - & - & - & 0 & - & - & $\circ$ & 0 & - & - & 0 & - & - & - & NISTms & 982 & 982 & - & - & Moio et al. (2000) \\
\hline 1-propanol & $71-23-8$ & - & $\bullet$ & 0 & 0 & • & • & • & • & $\bullet$ & - & • & • & - & - & - & - & - & - & • & - & - & 0 & - & 0 & NISTms & 588 & 595 & - & & Bylaite \& Meyer (2006) \\
\hline 2-methyl-1-propanol & $78-83-1$ & o & $\circ$ & - & 0 & $\circ$ & 0 & $\circ$ & 0 & 0 & $\circ$ & $\circ$ & $\circ$ & • & - & $\circ$ & - & $\circ$ & - & $\circ$ & - & - & 0 & - & $\circ$ & NISTms & 645 & 654 & 643 & - & Bylaite \& Meyer (2006) \\
\hline 2-methyl-3-buten-2-ol & $115-18-4$ & 0 & 0 & 0 & 0 & $\circ$ & 0 & $\circ$ & 0 & 0 & $\circ$ & $\circ$ & 0 & 0 & 0 & $\circ$ & $\circ$ & $\circ$ & - & 0 & - & $\circ$ & 0 & 0 & 0 & NISTms & 635 & 620 & 631 & & Pino et al. (2003) \\
\hline 2-propanol & $67-63-0$ & - & - & - & • & - & - & - & - & - & - & - & - & - & - & - & - & - & - & - & - & - & - & - & - & NISTms & 524 & 516 & - & - & Xu et al. (2003) \\
\hline 3-methyl-3-buten-1-ol & 763-32-6 & 0 & 0 & - & 0 & $\circ$ & $\circ$ & 0 & 0 & 0 & 0 & $\circ$ & o & $\circ$ & $\circ$ & 0 & 0 & 0 & 0 & 0 & $\circ$ & $\circ$ & 0 & 0 & $\circ$ & NISTms & 743 & 734 & 743 & & Moio \& Addeo (1998) \\
\hline Ethanol & $64-17-5$ & - & - & - & 0 & - & - & - & - & - & - & - & - & - & • & • & - & • & - & - & - & - & - & - & - & NISTms & 479 & 446 & - & - & Peng (1992) \\
\hline Isoamyl alcohol & $123-51-3$ & 0 & - & - & • & - & - & - & - & - & 0 & - & 0 & - & - & - & - & - & - & - & - & - & 0 & - & $\circ$ & NISTms & 745 & 750 & 745 & - & Komárek et al. (1998) \\
\hline Phenylethyl alcohol & $60-12-8$ & 0 & 0 & $\bullet$ & $\circ$ & $\circ$ & $\circ$ & $\circ$ & 0 & 0 & 0 & $\circ$ & 0 & 0 & $\circ$ & 0 & 0 & 0 & $\circ$ & 0 & 0 & 0 & 0 & $\circ$ & $\circ$ & NISTms & 1140 & 1141 & - & - & Rout et al. (2007) \\
\hline \multicolumn{32}{|l|}{ Aldehydes } \\
\hline 2-methylbutanal & $96-17-3$ & - & 0 & $\circ$ & $\circ$ & $\circ$ & 0 & 0 & 0 & 0 & 0 & $\circ$ & $\circ$ & 0 & $\circ$ & 0 & 0 & 0 & 0 & 0 & 0 & 0 & 0 & $\circ$ & $\circ$ & NISTms & 668 & 664 & - & - & Rychlik \& Bosset (2001) \\
\hline 3-methylbutanal & $590-86-3$ & - & 0 & 0 & $\circ$ & 0 & 0 & $\circ$ & 0 & 0 & 0 & $\circ$ & $\circ$ & 0 & 0 & 0 & 0 & 0 & 0 & 0 & 0 & $\circ$ & 0 & $\circ$ & $\circ$ & NISTms & 662 & 664 & - & - & Bylaite \& Meyer (2006) \\
\hline Hexanal & $66-25-1$ & - & 0 & $\circ$ & $\circ$ & 0 & $\circ$ & 0 & 0 & $\circ$ & 0 & 0 & $\circ$ & $\circ$ & 0 & $\circ$ & $\circ$ & $\circ$ & $\circ$ & 0 & 0 & 0 & $\circ$ & $\circ$ & $\circ$ & NISTms & 803 & 803 & - & - & Wu \& Cadwallader (2002) \\
\hline \multicolumn{32}{|l|}{ Alkenes } \\
\hline 1,3-octadiene & 1002-33-1 & $\circ$ & 0 & $\circ$ & $\circ$ & 0 & 0 & • & • & 0 & $\circ$ & - & 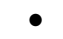 & $\circ$ & 0 & - & $\bullet$ & $\circ$ & $\circ$ & - & - & 0 & 0 & - & - & NISTms & 826 & 826 & - & - & Methven et al. (2007) \\
\hline 1,3-trans,5-trans-octatriene & $40087-62-5$ & $\circ$ & 0 & $\circ$ & $\circ$ & $\circ$ & o & 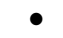 & • & $\circ$ & $\circ$ & 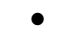 & 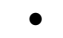 & 0 & 0 & 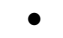 & 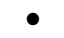 & $\circ$ & $\circ$ & - & - & $\circ$ & $\circ$ & $\circ$ & - & NISTms & 886 & 880 & - & - & Xie et al. (2007) \\
\hline 2,4,6-octatriene & $764-75-0$ & $\circ$ & 0 & 0 & 0 & $\circ$ & 0 & - & - & 0 & $\circ$ & & - & 0 & 0 & 列 & - & $\circ$ & 0 & - & - & 0 & $\circ$ & $\circ$ & - & NISTms & 937 & 925 & - & - & Montanarella et al. (1986) \\
\hline 3,5,5-trimethyl-2-hexene & $26456-76-8$ & $\circ$ & 0 & 0 & 0 & o & o & - & - & o & o & c & - & o & $\circ$ & 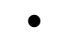 & • & $\circ$ & o & 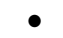 & 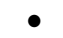 & o & $\circ$ & $\circ$ & o & NISTms & 979 & 985 & . & . & Duflos et al. (2005) \\
\hline
\end{tabular}


Table A.4.2. Continuation

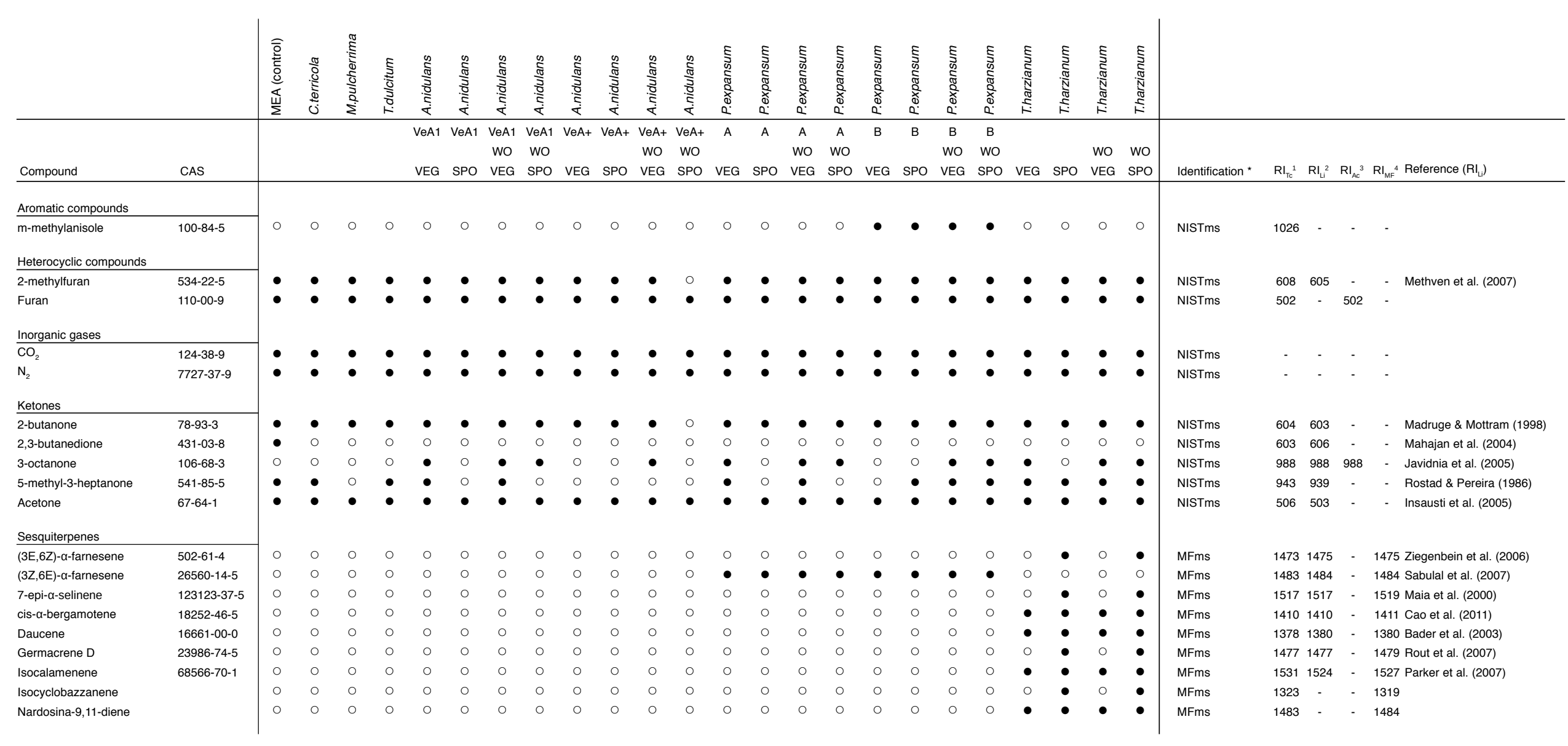

To be continued 
Table A.4.2: Continuation

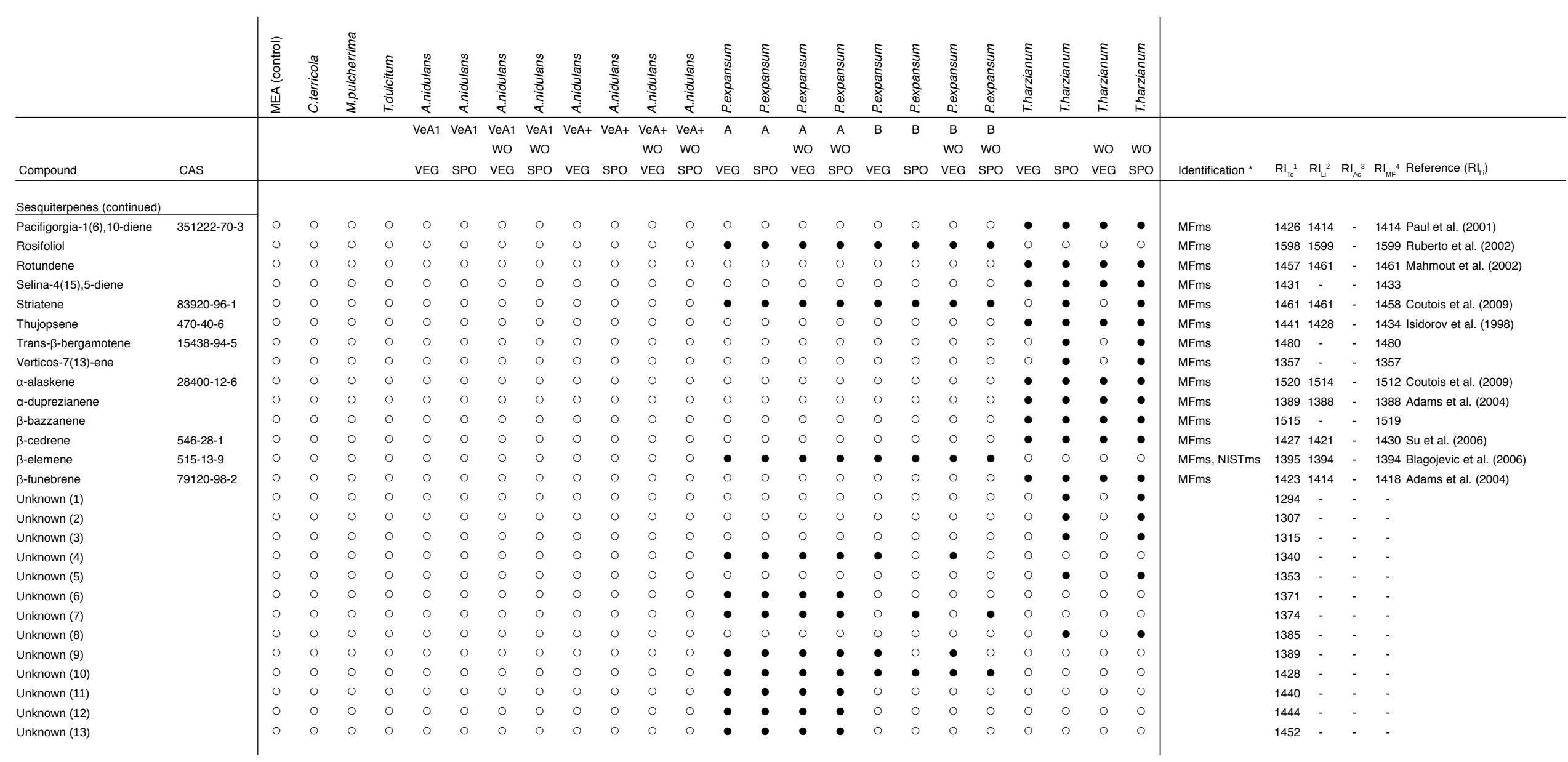


Table A.4.2. Continuation

\begin{tabular}{|c|c|c|c|c|c|c|c|c|c|c|c|c|c|c|c|c|c|c|c|c|c|c|c|c|c|c|c|c|c|c|c|}
\hline & & 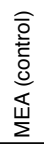 & $\begin{array}{l}\frac{\pi}{0} \\
0 \\
0 \\
0 \\
0 \\
\end{array}$ & 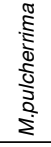 & 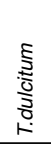 & 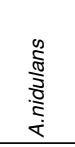 & 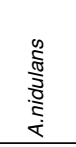 & 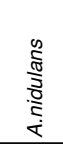 & 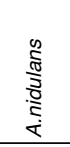 & 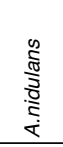 & 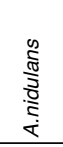 & 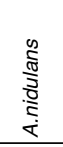 & 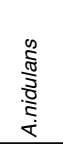 & $\begin{array}{r}5 \\
5 \\
0 \\
\frac{5}{0} \\
0 \\
0 \\
0 \\
0 \\
\end{array}$ & $\begin{array}{l}\sqrt{5} \\
50 \\
0 \\
0 \\
0 \\
0 \\
0 \\
0 \\
\end{array}$ & 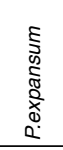 & 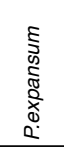 & 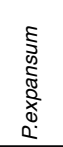 & 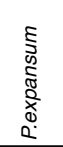 & $\begin{array}{l}\text { క } \\
0 \\
\mathbb{0} \\
\mathbb{0} \\
\mathbf{0} \\
0 \\
0\end{array}$ & 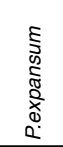 & 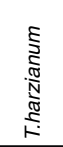 & 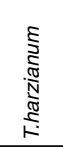 & 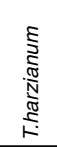 & 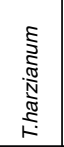 & & & & & & \\
\hline Compound & CAS & & & & & $\begin{array}{l}\text { VeA1 } \\
\text { VEG }\end{array}$ & $\begin{array}{l}\text { VeA1 } \\
\text { SPO }\end{array}$ & $\begin{array}{c}\text { VeA1 } \\
\text { WO } \\
\text { VEG }\end{array}$ & $\begin{array}{l}\text { VeA1 } \\
\text { WO } \\
\text { SPO }\end{array}$ & $\begin{array}{l}\text { VeA+ } \\
\text { VEG }\end{array}$ & $\begin{array}{l}\text { VeAt } \\
\text { SPO }\end{array}$ & $\begin{array}{l}\text { VeAt } \\
\text { WO } \\
\text { VEG }\end{array}$ & $\begin{array}{l}\text { VeAt } \\
\text { WO } \\
\text { SPO }\end{array}$ & VEG & $\begin{array}{c}\text { A } \\
\text { SPO }\end{array}$ & $\begin{array}{c}\text { A } \\
W O \\
\text { VEG }\end{array}$ & $\begin{array}{c}\text { A } \\
\text { WO } \\
\text { SPO }\end{array}$ & $\begin{array}{c}\text { B } \\
\text { VEG }\end{array}$ & $\begin{array}{c}\text { B } \\
\text { SPO }\end{array}$ & $\begin{array}{c}\text { B } \\
\text { WO } \\
\text { VEG }\end{array}$ & $\begin{array}{c}\text { B } \\
\text { WO } \\
\text { SPO }\end{array}$ & VEG & SPO & $\begin{array}{l}\text { Wo } \\
\text { VEG }\end{array}$ & $\begin{array}{l}\text { Wo } \\
\text { SPO }\end{array}$ & Identification * & $\mathrm{RI}_{\mathrm{TC}_{\mathrm{C}}{ }^{1} \mathrm{C}}$ & $\mathrm{RI}_{\mathrm{L}}{ }^{2}$ & $\mathrm{RI}_{A C}{ }^{3}$ & $\mathrm{RI}_{\mathrm{ME}}{ }^{4} \mathrm{I}$ & Reference $\left(\mathrm{R}_{\mathrm{L}}\right)$ \\
\hline \multicolumn{2}{|c|}{ Sesquiterpenes (continued) } & & & & & & & & & & & & & & & & & & & & & & & & & & & & & & \\
\hline \multicolumn{2}{|l|}{ Unknown (14) } & 0 & $\circ$ & $\circ$ & $\circ$ & $\circ$ & 0 & $\circ$ & $\circ$ & 0 & 0 & $\circ$ & 0 & 0 & 0 & 0 & 0 & 0 & $\circ$ & $\circ$ & 0 & - & - & - & $\bullet$ & MFms & 1492 & - & - & -1 & Barley \& Jacobs (2000) \\
\hline \multicolumn{2}{|l|}{ Unknown (15) } & 0 & $\circ$ & 0 & 0 & 0 & $\circ$ & $\circ$ & $\circ$ & 0 & 0 & 0 & 0 & - & - & - & - & - & - & - & - & - & - & - & • & MFms & 1503 & 3 & - & -1 & Rout et al. (2007) \\
\hline \multicolumn{2}{|l|}{ Unknown (16) } & 0 & $\circ$ & 0 & 0 & 0 & o & $\circ$ & $\circ$ & 0 & o & $\circ$ & 0 & • & - & - & - & - & - & - & - & o & $\circ$ & $\circ$ & $\circ$ & & 1515 & 5 & - & - & \\
\hline \multicolumn{2}{|l|}{ Unknown (17) } & 0 & 0 & 0 & $\circ$ & 0 & $\circ$ & $\circ$ & 0 & $\circ$ & 0 & $\circ$ & 0 & 0 & 0 & 0 & 0 & $\circ$ & 0 & $\circ$ & 0 & $\circ$ & - & $\circ$ & - & & 1529 & - & - & - & \\
\hline \multirow{2}{*}{\multicolumn{2}{|c|}{$\begin{array}{l}\text { Unknown (18) } \\
\text { Unknown (19) }\end{array}$}} & 0 & 0 & 0 & 0 & 0 & 0 & 0 & 0 & 0 & 0 & 0 & 0 & 0 & 0 & 0 & 0 & 0 & 0 & $\circ$ & 0 & - & - & - & $\bullet$ & & 1542 & $2-$ & - & - & \\
\hline & & 0 & 0 & 0 & 0 & 0 & 0 & $\circ$ & $\circ$ & 0 & 0 & 0 & 0 & 0 & 0 & 0 & 0 & $\circ$ & 0 & 0 & 0 & - & - & - & • & & 1553 & $3-$ & - & - & \\
\hline \multicolumn{32}{|l|}{ Sesquiterpenoids } \\
\hline \multirow{2}{*}{\multicolumn{2}{|c|}{$\begin{array}{l}\text { (E)-nerolidol } \\
\text { Aromadendran-14-ol }\end{array}$}} & 0 & 0 & $\circ$ & $\circ$ & $\circ$ & 0 & $\circ$ & 0 & 0 & 0 & 0 & 0 & - & - & - & - & - & - & - & - & 0 & 0 & $\circ$ & o & NISTms & 1568 & 1569 & - & 1553 & Sabulal et al. (2007) \\
\hline & & 0 & 0 & 0 & $\circ$ & o & 0 & 0 & 0 & 0 & 0 & 0 & 0 & 0 & 0 & 0 & 0 & 0 & 0 & $\circ$ & 0 & - & - & • & $\bullet$ & MFms & 1678 & 3 - & - & 1679 & \\
\hline \multicolumn{32}{|l|}{ Terpenes } \\
\hline 2-methyl-2-bornene & $72540-93-3$ & 0 & $\circ$ & 0 & 0 & $\circ$ & $\circ$ & $\circ$ & $\circ$ & 0 & 0 & $\circ$ & 0 & - & - & - & - & - & - & - & - & 0 & $\circ$ & $\circ$ & 0 & NISTms & 1015 & 51021 & - & - & Dickschat et al. (2005) \\
\hline 2-methylenebornane & $27538-47-2$ & 0 & $\circ$ & 0 & 0 & 0 & $\circ$ & $\circ$ & $\circ$ & 0 & o & $\circ$ & 0 & - & - & - & - & - & - & - & - & 0 & $\circ$ & $\circ$ & 0 & NISTms & 983 & & - & - & \\
\hline 2methylisoborneol & $2371-42-8$ & 0 & $\circ$ & 0 & $\circ$ & 0 & o & $\circ$ & o & 0 & $\circ$ & $\circ$ & 0 & - & - & - & - & - & - & - & - & $\circ$ & $\circ$ & $\circ$ & 0 & NISTms & 1184 & 1182 & 1184 & -1 & Mahmout \& Buettner (2017) \\
\hline Geosmin & $19700-21-1$ & 0 & $\circ$ & $\circ$ & $\circ$ & 0 & 0 & $\circ$ & 0 & 0 & 0 & $\circ$ & 0 & - & - & - & - & - & - & - & - & $\circ$ & $\circ$ & $\circ$ & 0 & MFms, NISTms & 1413 & 31428 & 1420 & 1392 & Selli et al. (2006) \\
\hline Limonene & $138-86-3$ & - & - & - & - & - & - & - & - & • & - & - & - & - & - & - & - & - & - & - & - & - & - & - & - & NISTms & 1030 & 1030 & - & - & Javidnia et al. (2003) \\
\hline Unknown (20) & & 0 & o & 0 & 0 & o & o & $\circ$ & 0 & $\circ$ & o & o & o & - & - & - & - & - & - & - & • & o & o & o & o & & 1238 & & . & - & \\
\hline \multicolumn{32}{|l|}{ Terpenoids } \\
\hline Dihydroedulan I & $63335-66-0$ & 0 & $\circ$ & $\circ$ & $\circ$ & $\circ$ & $\circ$ & $\circ$ & $\circ$ & ○ & $\circ$ & $\circ$ & o & $\circ$ & $\circ$ & $\circ$ & $\circ$ & $\circ$ & $\bullet$ & $\circ$ & $\bullet$ & $\circ$ & ○ & $\circ$ & o & NISTms & 1299 & 1300 & - & -2 & Zhao et al. (2005) \\
\hline \multicolumn{2}{|l|}{ Unknown compounds } & & & & & & & & & & & & & & & & & & & & & & & & & & & & & & \\
\hline \multicolumn{2}{|l|}{ Unknown (21) } & 0 & $\circ$ & 0 & $\circ$ & $\circ$ & 0 & $\circ$ & 0 & $\circ$ & $\circ$ & $\circ$ & $\circ$ & 0 & 0 & $\circ$ & $\circ$ & $\circ$ & $\circ$ & $\circ$ & $\circ$ & $\circ$ & - & $\circ$ & - & & 1326 & - & - & - & \\
\hline \multirow{2}{*}{\multicolumn{2}{|c|}{ Unknown (22) }} & 0 & 0 & 0 & 0 & 0 & 0 & 0 & 0 & 0 & o & 0 & 0 & $\bullet$ & 0 & - & o & 0 & 0 & 0 & 0 & 0 & 0 & $\circ$ & 0 & & 1331 & - & - & - & \\
\hline & Unknown (23) & 0 & 0 & $\circ$ & $\circ$ & 0 & 0 & $\circ$ & 0 & 0 & 0 & o & 0 & 0 & 0 & 0 & 0 & 0 & $\circ$ & 0 & 0 & 0 & - & o & • & & 1336 & - & - & - & \\
\hline \multicolumn{2}{|l|}{ Unknown (24) } & 0 & $\circ$ & 0 & $\circ$ & 0 & 0 & $\circ$ & 0 & 0 & 0 & o & 0 & 0 & 0 & 0 & 0 & 0 & $\circ$ & 0 & 0 & 0 & • & $\circ$ & • & & 1343 & 3 - & - & - & \\
\hline \multicolumn{2}{|l|}{ Unknown (25) } & 0 & 0 & $\circ$ & $\circ$ & 0 & 0 & 0 & 0 & 0 & 0 & 0 & 0 & 0 & $\circ$ & 0 & 0 & 0 & $\circ$ & $\circ$ & 0 & 0 & - & $\circ$ & - & & 1371 & - & - & - & \\
\hline
\end{tabular}

To be continued 
Table A.4.2: Continuation

\begin{tabular}{|c|c|c|c|c|c|c|c|c|c|c|c|c|c|c|c|c|c|c|c|c|c|c|c|c|c|c|c|c|c|c|}
\hline & & 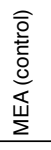 & 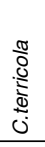 & 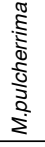 & 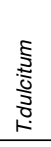 & 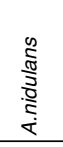 & 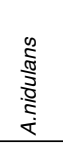 & 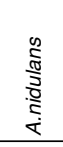 & 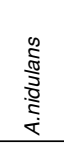 & 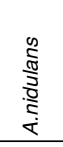 & 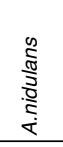 & 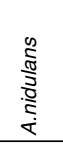 & 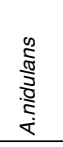 & 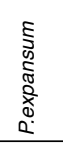 & 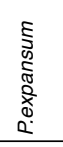 & 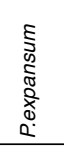 & $\begin{array}{l}5 \\
5 \\
0 \\
\mathbb{1} \\
0 \\
0 \\
0 \\
0 \\
\end{array}$ & 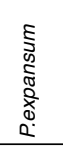 & 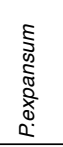 & 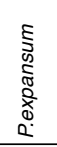 & 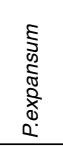 & 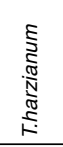 & 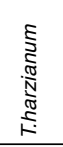 & 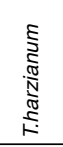 & 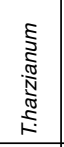 & & & & & \\
\hline Compound & CAS & & & & & VeA1 & VeA1 & $\begin{array}{l}\text { VeA1 } \\
\text { WO } \\
\text { VEG }\end{array}$ & $\begin{array}{l}\text { VeA1 } \\
\text { WO } \\
\text { SPO }\end{array}$ & VeAt & VeAt & $\begin{array}{l}\text { VeA+ } \\
\text { WO } \\
\text { VEG }\end{array}$ & $\begin{array}{l}\text { VeAt } \\
\text { WO } \\
\text { SPO }\end{array}$ & VEG & SPO & $\begin{array}{c}\text { A } \\
\text { WO } \\
\text { VEG }\end{array}$ & $\begin{array}{c}\text { A } \\
\text { Wo } \\
\text { SPO }\end{array}$ & VEG & SPO & $\begin{array}{c}\text { B } \\
\text { WO } \\
\text { VEG }\end{array}$ & $\begin{array}{c}\text { B } \\
\text { WO } \\
\text { SPO }\end{array}$ & VEG & SPO & $\begin{array}{l}\text { Wo } \\
\text { VEG }\end{array}$ & $\begin{array}{l}\text { wo } \\
\text { SPO }\end{array}$ & Identification * & $\mathrm{RI}_{-}{ }^{1}$ & $\mathrm{RI}^{2} \mathrm{~F}^{2}$ & $\mathrm{RI}^{3} \mathrm{R}$ & $\mathrm{RI}{ }_{W}{ }^{4}$ Reference $\left(\mathrm{RI}{ }_{\mu}\right)$ \\
\hline Unknown comp & & & & & & & & & & & & & & & & & & & & & & & & & & & & & & \\
\hline Unknown (26) & & $\circ$ & $\circ$ & 0 & $\circ$ & 0 & 0 & $\circ$ & 0 & 0 & 0 & 0 & 0 & 0 & 0 & 0 & 0 & 0 & 0 & 0 & 0 & - & - & - & - & & 1397 & - & - & - \\
\hline Unknown (27) & & $\circ$ & $\circ$ & 0 & $\circ$ & 0 & 0 & $\circ$ & 0 & 0 & 0 & 0 & 0 & 0 & - & 0 & - & - & - & - & - & 0 & 0 & 0 & 0 & & 1556 & - & - & - \\
\hline Unknown (28) & & $\circ$ & $\circ$ & $\circ$ & $\circ$ & 0 & 0 & $\circ$ & 0 & 0 & $\circ$ & 0 & 0 & 0 & 0 & $\circ$ & 0 & 0 & $\circ$ & $\circ$ & 0 & - & - & - & - & & 1700 & - & - & - \\
\hline Unknown (29) & & $\circ$ & $\circ$ & $\circ$ & $\circ$ & 0 & 0 & $\circ$ & 0 & 0 & $\circ$ & 0 & 0 & 0 & • & 0 & - & 0 & - & 0 & - & 0 & 0 & $\circ$ & 0 & & 1725 & 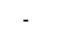 & - & - \\
\hline Unknown (30) & & $\circ$ & $\circ$ & $\circ$ & 0 & 0 & 0 & $\circ$ & 0 & 0 & $\circ$ & $\circ$ & 0 & 0 & - & 0 & - & 0 & - & 0 & - & $\circ$ & 0 & $\circ$ & 0 & & 1753 & - & - & - \\
\hline Unknown (31) & & 0 & 0 & 0 & 0 & 0 & 0 & 0 & 0 & 0 & 0 & 0 & 0 & 0 & 0 & 0 & 0 & 0 & 0 & 0 & 0 & - & - & - & - & & 1767 & - & - & - \\
\hline Unknown (32) & & 0 & 0 & 0 & 0 & 0 & 0 & $\circ$ & 0 & 0 & 0 & 0 & 0 & 0 & $\bullet$ & 0 & - & 0 & - & 0 & - & 0 & 0 & 0 & 0 & & - & - & - & - \\
\hline Unknown (33) & & $\circ$ & $\circ$ & $\circ$ & $\circ$ & o & o & $\circ$ & o & 0 & 0 & o & 0 & - & - & - & - & o & - & 0 & • & o & 0 & 0 & o & & - & - & - & - \\
\hline Unknown (34) & & $\circ$ & $\circ$ & 0 & $\circ$ & o & 0 & $\circ$ & o & 0 & 0 & o & 0 & o & • & 0 & - & o & - & 0 & - & o & 0 & 0 & 0 & & - & - & - & - \\
\hline Unknown (35) & & $\circ$ & 0 & $\circ$ & $\circ$ & o & o & 0 & o & 0 & 0 & o & 0 & o & - & 0 & - & o & - & o & - & o & 0 & 0 & 0 & & - & - & - & - \\
\hline Unknown (36) & & $\circ$ & $\circ$ & 0 & $\circ$ & o & o & $\circ$ & o & 0 & 0 & o & 0 & o & o & 0 & o & o & 0 & o & 0 & - & - & - & - & & - & - & - & - \\
\hline Unknown (37) & & $\circ$ & $\circ$ & o & $\circ$ & o & o & o & o & 0 & o & o & 0 & o & - & o & - & o & - & o & - & o & 0 & o & o & & - & - & - & - \\
\hline Unknown (38) & & $\circ$ & $\circ$ & 0 & $\circ$ & 0 & 0 & 0 & 0 & o & 0 & 0 & 0 & 0 & - & 0 & - & o & - & o & - & o & o & 0 & 0 & & - & - & - & - \\
\hline Unknown (39) & & $\circ$ & o & o & $\circ$ & o & o & o & o & o & o & o & o & o & o & o & o & o & o & o & o & - & - & - & - & & . & . & . & - \\
\hline Unknown (40) & & $\circ$ & $\circ$ & $\circ$ & $\circ$ & o & 0 & $\circ$ & $\circ$ & 0 & $\circ$ & o & 0 & o & 0 & $\circ$ & $\circ$ & 0 & $\circ$ & $\circ$ & o & - & - & - & - & & - & - & - & - \\
\hline Unknown (41) & & $\circ$ & $\circ$ & 0 & $\circ$ & 0 & 0 & o & 0 & 0 & 0 & 0 & 0 & 0 & - & o & - & 0 & - & o & - & 0 & 0 & 0 & 0 & & - & - & - & - \\
\hline Unknown (42) & & $\circ$ & $\circ$ & 0 & $\circ$ & 0 & o & 0 & o & 0 & 0 & o & 0 & 0 & 0 & $\circ$ & 0 & 0 & o & o & 0 & - & - & - & - & & - & - & - & - \\
\hline Unknown (43) & & $\circ$ & o & 0 & 0 & 0 & 0 & 0 & 0 & 0 & 0 & 0 & 0 & 0 & o & 0 & 0 & 0 & o & 0 & o & & & - & - & & - & - & - & - \\
\hline
\end{tabular}

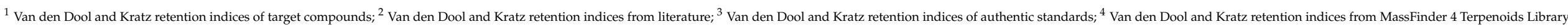
* Identification by mass spectrum of NIST library with minimum match of 800 (NISTms), and/or Mass Finder Terpenoids Library (MFms) 
Table A.4.3: Wilcoxon test statistic - Effect of fungal tissue wounding on quantities (manually integrated peak areas) of volatile compounds detected in headspace samples of vegetative and sporulating colonies of filamentous fungi A. nidulans (two genotypes), P. expansum (two genotypes), and T. harzianum. Naturally, woundactivated compounds that were solely detected in wounded colonies were not tested and thus are not mentioned in this table.

\begin{tabular}{|c|c|c|c|}
\hline Compound & & $Z$ & $P$-value \\
\hline \multicolumn{4}{|c|}{ A. nidulans, VeA1, vegetative } \\
\hline 3-methyl-1-butanol & & -0.16 & 0.937 \\
\hline 1-octen-3-ol & & -2.91 & 0.002 \\
\hline 3-octanone & & -2.88 & 0.002 \\
\hline \multicolumn{4}{|c|}{ A. nidulans, VeA1, sporulating } \\
\hline 3-methyl-1-butanol & & -0.26 & 0.870 \\
\hline \multicolumn{4}{|c|}{ A. nidulans, $\mathrm{VeA}+$, vegetative } \\
\hline 3-methyl-1-butanol & & -0.80 & 0.455 \\
\hline 1-octen-3-ol & & -2.88 & 0.002 \\
\hline
\end{tabular}

A. nidulans, VeAt, sporulating

(no compounds detected)

3-methyl-1-butanol

P. expansum, A, vegetative

1-octen-3-ol

3-octanone

$(3 Z, 6 \mathrm{E})-\alpha$-farnesene

Rosifoliol

Striatene

$\beta$-elemene

(E)-Nerolidol

2-methylenebornane

2-methyl-2-bornene

2-methyisoborneol

Geosmin

Unknown (4)

Unknown (6)

Unknown (7)

Unknown (9)

Unknown (10)

Unknown (11)

Unknown (12)

Unknown (13)

Unknown (15)

Unknown (16)

Unknown (20)

Unknown (22)

Unknown (33)

\begin{tabular}{c|c}
-0.80 & 0.485 \\
-2.89 & $\mathbf{0 . 0 0 2}$ \\
-2.72 & $\mathbf{0 . 0 0 4}$ \\
-0.16 & 0.937 \\
1.12 & 0.310 \\
-0.16 & 0.937 \\
0.16 & 0.937 \\
1.66 & 0.113 \\
0.32 & 0.818 \\
1.12 & 0.310 \\
0.96 & 0.394 \\
0.16 & 0.937 \\
0.80 & 0.485 \\
-0.26 & 0.870 \\
1.44 & 0.169 \\
0.32 & 0.818 \\
0.96 & 0.394 \\
0.32 & 0.814 \\
1.44 & 0.180 \\
0.48 & 0.700 \\
0.80 & 0.485 \\
-0.80 & 0.485 \\
0 & 1 \\
0.16 & 0.937 \\
0.16 & 0.939
\end{tabular}

To be continued 


\section{Table A.4.3 Continuation}

2-methyl-1-propanol

3-methyl-1-butanol

P. expansum, A, sporulating

(3Z,6E)- $\alpha$-farnesene

Rosifoliol

Striatene

$\beta$-elemene

(E)-Nerolidol

2-methylenebornane

2-methyl-2-bornene

2-methyisoborneol

Geosmin

Unknown (4)

Unknown (6)

Unknown (7)

Unknown (9)

Unknown (10)

Unknown (11)

Unknown (12)

Unknown (13)

Unknown (15)

Unknown (16)

Unknown (20)

Unknown (27)

Unknown (29)

Unknown (32)

Unknown (33)

Unknown (34)

Unknown (35)

Unknown (37)

Unknown (38)

Unknown (41)

\begin{tabular}{|c|c}
0.80 & 0.485 \\
-0.64 & 0.589 \\
0.54 & 0.697 \\
-0.32 & 0.777 \\
0.90 & 0.407 \\
-0.16 & 0.937 \\
1.33 & 0.221 \\
-0.64 & 0.589 \\
0.32 & 0.818 \\
0 & 1 \\
0.16 & 0.937 \\
0.54 & 0.697 \\
0 & 1 \\
-1.20 & 0.255 \\
0.60 & 0.590 \\
1.13 & 0.307 \\
-0.89 & 0.394 \\
1.47 & 0.147 \\
-0.32 & 0.818 \\
0.16 & 0.937 \\
-1.12 & 0.310 \\
-0.64 & 0.589 \\
0.16 & 0.937 \\
-0.96 & 0.394 \\
0 & 0 \\
0.48 & 0.699 \\
-0.80 & 0.485 \\
0.16 & 0.937 \\
0.64 & 0.589 \\
-0.48 & 0.699 \\
0 & 1 \\
\hline
\end{tabular}

3-methyl-1-butanol

(3Z,6E)- $\alpha$-farnesene

Rosifoliol

Striatene

$\beta$-elemene

\begin{tabular}{l|l}
-1.12 & 0.310 \\
-0.48 & 0.699 \\
1.92 & 0.065 \\
-0.32 & 0.818 \\
-0.16 & 0.937 \\
0.24 & 0.859 \\
-0.43 & 0.708 \\
-0.16 & 0.937 \\
-1.60 & 0.132 \\
-1.28 & 0.240 \\
\hline
\end{tabular}

To be continued 


\section{Table A.4.3 Continuation}

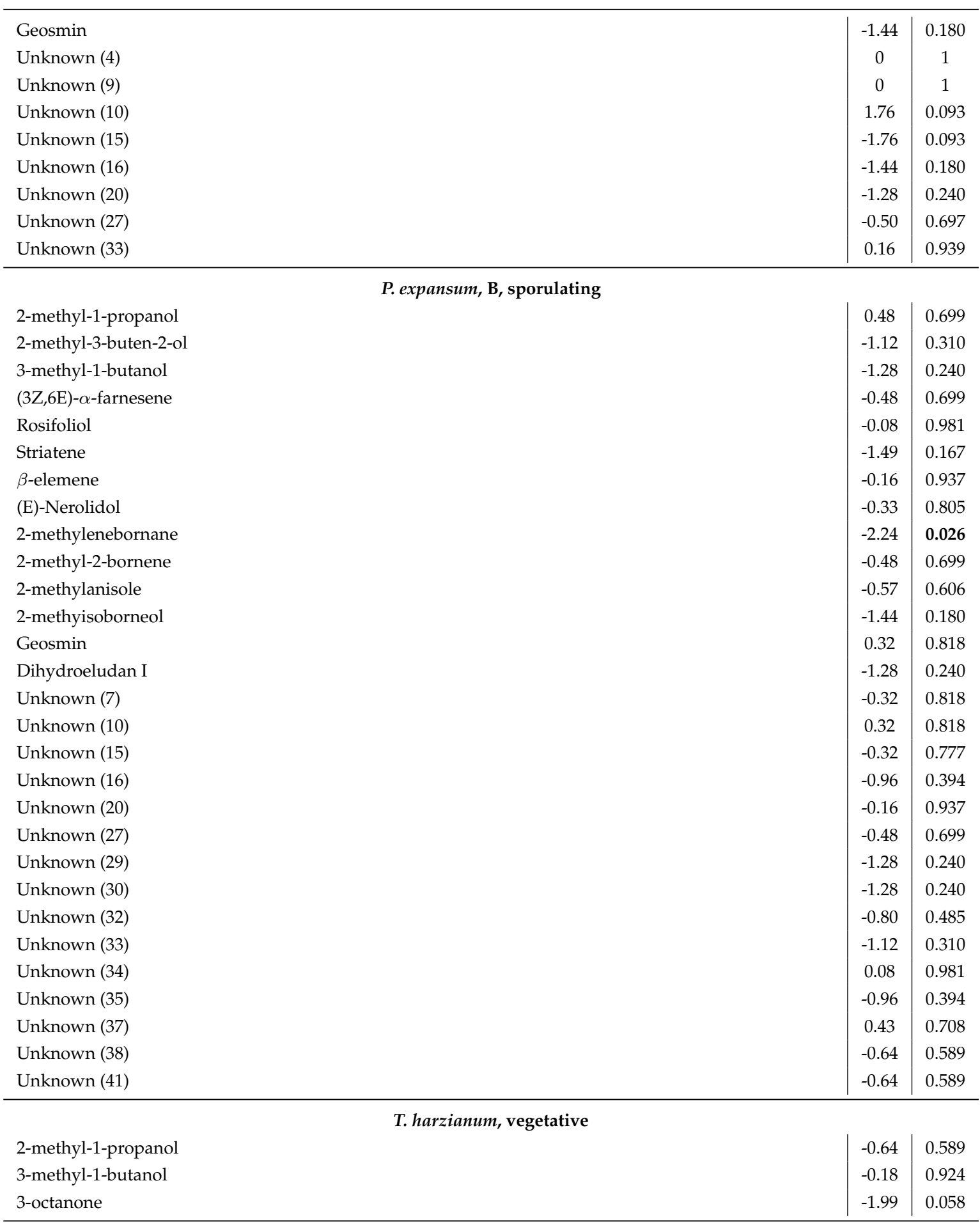

To be continued 


\section{Table A.4.3 Continuation}

\begin{tabular}{|c|c|c|}
\hline Daucene & 0 & 1 \\
\hline$\alpha$-duprezianene & 0.32 & 0.818 \\
\hline cis- $\alpha$-bergamotene & -0.32 & 0.818 \\
\hline$\beta$-funebrene & 0.32 & 0.818 \\
\hline Pacifigorgia-1(6),10-diene & 0 & 1 \\
\hline$\beta$-cedrene & -0.16 & 0.937 \\
\hline Selina-4(15),5-diene & 0.32 & 0.818 \\
\hline Thujopsene & 0.64 & 0.589 \\
\hline Rotundene & 0.80 & 0.485 \\
\hline trans- $\beta$-bergamotene & -2.24 & 0.026 \\
\hline Nardosina-9,11-diene & -0.16 & 0.937 \\
\hline$\beta$-bazzanene & 0.48 & 0.699 \\
\hline$\alpha$-alaskene & 0.16 & 0.937 \\
\hline Isocalamenene & -0.16 & 0.937 \\
\hline Aromadendran-14-ol & -0.32 & 0.818 \\
\hline Unknown (14) & 0.32 & 0.818 \\
\hline Unknown (15) & 0.16 & 0.937 \\
\hline Unknown (18) & -0.16 & 0.937 \\
\hline Unknown (19) & -0.32 & 0.777 \\
\hline Unknown (26) & 0.48 & 0.699 \\
\hline Unknown (28) & -0.64 & 0.589 \\
\hline Unknown (31) & 0.64 & 0.589 \\
\hline Unknown (36) & 0.64 & 0.554 \\
\hline Unknown (39) & 0.80 & 0.485 \\
\hline Unknown (40) & -0.16 & 0.937 \\
\hline Unknown (42) & 0.80 & 0.485 \\
\hline Unknown (43) & 0.96 & 0.394 \\
\hline \multicolumn{3}{|c|}{ T. harzianum, sporulating } \\
\hline 1-octen-3-ol & -2.93 & 0.002 \\
\hline$(3 Z, 6 \mathrm{E})-\alpha$-farnesene & -0.48 & 0.699 \\
\hline 7-epi- $\alpha$-selinene & -0.80 & 0.485 \\
\hline Daucene & -0.64 & 0.589 \\
\hline Germacrene D & -0.80 & 0.485 \\
\hline cis- $\alpha$-bergamotene & -1.60 & 0.123 \\
\hline$\beta$-funebrene & -2.08 & 0.041 \\
\hline Pacifigorgia-1(6),10-diene & 1.60 & 0.123 \\
\hline$\beta$-cedrene & -1.92 & 0.065 \\
\hline Selina-4(15),5-diene & -1.12 & 0.310 \\
\hline Striatene & -0.64 & 0.589 \\
\hline Thujopsene & 1.60 & 0.123 \\
\hline Rotundene & 1.60 & 0.123 \\
\hline Nardosina-9,11-diene & -2.40 & 0.015 \\
\hline Verticos-7(13)-ene & -0.64 & 0.589 \\
\hline
\end{tabular}

To be continued 


\section{Table A.4.3 Continuation}

\begin{tabular}{l|c|c}
\hline$\alpha$-alaskene & -1.76 & 0.093 \\
$\alpha$-duprezianene & -0.48 & 0.699 \\
$\beta$-bazzanene & -0.50 & 0.697 \\
Isocalamenene & -1.29 & 0.234 \\
Isocyclobazzanene & -1.12 & 0.310 \\
Aromadendran-14-ol & -1.28 & 0.240 \\
Unknown (1) & -1.92 & 0.065 \\
Unknown (2) & -1.28 & 0.240 \\
Unknown (3) & -1.60 & 0.132 \\
Unknown (5) & -0.64 & 0.589 \\
Unknown (8) & -1.44 & 0.180 \\
Unknown (14) & -1.12 & 0.310 \\
Unknown (15) & -0.80 & 0.485 \\
Unknown (17) & 0.08 & 1 \\
Unknown (18) & -1.76 & 0.093 \\
Unknown (19) & -1.12 & 0.310 \\
Unknown (21) & -0.96 & 0.394 \\
Unknown (23) & -1.44 & 0.180 \\
Unknown (24) & -0.16 & 0.937 \\
Unknown (25) & -0.64 & 0.589 \\
Unknown (26) & -2.08 & $\mathbf{0 . 0 4 1}$ \\
Unknown (28) & -1.12 & 0.310 \\
Unknown (31) & -1.60 & 0.123 \\
Unknown (36) & 0.41 & 0.706 \\
Unknown (39) & 0.16 & 0.937 \\
Unknown (40) & 0 & 1 \\
Unknown (42) & -0.32 & 0.814 \\
Unknown (43) & 0 & 1 \\
\hline & & 0.93 \\
\hline
\end{tabular}


Table A.4.4: On-patch contact behaviour raw data on the 'duration of the first feeding event' (First F dur), 'total feeding time' (Total feeding), and 'patch contact frequency prior feeding' (Contacts prior F).

\begin{tabular}{|c|c|c|c|c|}
\hline Observation number & Treatment & First F dur (sec) & Time: feeding $(\%)$ & Contacts prior F (freq) \\
\hline 1 & C. terricola & & 0 & \\
\hline 2 & C. terricola & & 0 & \\
\hline 3 & C. terricola & 41.792 & 55.75 & 0.0256 \\
\hline 4 & C. terricola & & 0 & \\
\hline 5 & C. terricola & & 0 & \\
\hline 6 & C. terricola & 28.103 & 28.49 & 0.0199 \\
\hline 7 & C. terricola & & 0 & \\
\hline 8 & C. terricola & & 0 & \\
\hline 9 & C. terricola & 58.558 & 3.90 & 0.0319 \\
\hline 10 & C. terricola & & 0 & \\
\hline 11 & C. terricola & & 0 & \\
\hline 12 & C. terricola & & 0 & \\
\hline 13 & C. terricola & & 0 & \\
\hline 14 & C. terricola & & 0 & \\
\hline 15 & C. terricola & & 0 & \\
\hline 16 & C. terricola & & 0 & \\
\hline 17 & C. terricola & & 0 & \\
\hline 18 & C. terricola & & 0 & \\
\hline 19 & C. terricola & & 0 & \\
\hline 20 & C. terricola & 13.191 & 24.66 & 0.0177 \\
\hline 1 & M. pulcherrima & & 0 & \\
\hline 2 & M. pulcherrima & 104.468 & 6.96 & 0.0465 \\
\hline 3 & M. pulcherrima & 571.568 & 49.61 & 0.0022 \\
\hline 4 & M. pulcherrima & & 0 & \\
\hline 5 & M. pulcherrima & & 0 & \\
\hline 6 & M. pulcherrima & 33.886 & 2.26 & 0.0330 \\
\hline 7 & M. pulcherrima & & 0 & \\
\hline 8 & M. pulcherrima & & 0 & \\
\hline 9 & M. pulcherrima & & 0 & \\
\hline 10 & M. pulcherrima & & 0 & \\
\hline 11 & M. pulcherrima & 58.086 & 3.88 & 0.0292 \\
\hline 12 & M. pulcherrima & & 0 & \\
\hline 13 & M. pulcherrima & 59.852 & 4.04 & 0.0040 \\
\hline 14 & M. pulcherrima & & 0 & \\
\hline 15 & M. pulcherrima & 22.315 & 49.26 & 0.0065 \\
\hline 16 & M. pulcherrima & & 0 & \\
\hline 17 & M. pulcherrima & & 0 & \\
\hline 18 & M. pulcherrima & & 0 & \\
\hline 19 & M. pulcherrima & & 0 & \\
\hline 20 & M. pulcherrima & & 0 & \\
\hline 1 & T. dulcitum & & 0 & \\
\hline 2 & T. dulcitum & 38.966 & 2.60 & 0.0042 \\
\hline 3 & T. dulcitum & & 0 & \\
\hline 4 & T. dulcitum & 263.18 & 21.87 & 0.0037 \\
\hline 5 & T. dulcitum & 247.042 & 16.47 & 0.0060 \\
\hline 6 & T. dulcitum & 107.081 & 69.95 & 0.0207 \\
\hline 7 & T. dulcitum & 61.272 & 67.24 & 0.0281 \\
\hline 8 & T. dulcitum & 9.33 & 0.62 & 0.0034 \\
\hline 9 & T. dulcitum & 149.01 & 46.48 & 0.0162 \\
\hline 10 & T. dulcitum & & 0 & \\
\hline 11 & T. dulcitum & & 0 & \\
\hline 12 & T. dulcitum & & 0 & \\
\hline 13 & T. dulcitum & & 0 & \\
\hline 14 & T. dulcitum & & 0 & \\
\hline 15 & T. dulcitum & 58.347 & 3.89 & 0.0044 \\
\hline 16 & T. dulcitum & & 0 & \\
\hline 17 & T. dulcitum & & 0 & \\
\hline 18 & T. dulcitum & & 0 & \\
\hline 19 & T. dulcitum & 80.605 & 28.13 & 0.0041 \\
\hline 20 & T. dulcitum & & 0 & \\
\hline
\end{tabular}

To be continued 


\section{Table A.4.4 Continuation}

\begin{tabular}{|c|c|c|c|c|}
\hline Observation number & Treatment & First F dur $(\mathrm{sec})$ & Total feeding (\%) & Contacts prior $F$ (freq) \\
\hline 1 & A. nidulans & \multirow{4}{*}{151.666} & 0 & \multirow{4}{*}{0.0334} \\
\hline 2 & A. nidulans & & 0 & \\
\hline 3 & A. nidulans & & 10.11 & \\
\hline 4 & A. nidulans & & 0 & \\
\hline 5 & A. nidulans & 1.11 & 1.50 & 0.0530 \\
\hline 6 & A. nidulans & \multirow[t]{2}{*}{67.443} & 52.97 & \multirow[t]{2}{*}{0.0337} \\
\hline 7 & A. nidulans & & 0 & \\
\hline 8 & A. nidulans & 31.129 & 2.08 & 0.0109 \\
\hline 9 & A. nidulans & 631.979 & 42.13 & 0.0104 \\
\hline 10 & A. nidulans & \multirow[t]{11}{*}{1391.867} & 95.25 & \multirow[t]{11}{*}{0.0144} \\
\hline 11 & A. nidulans & & 0 & \\
\hline 12 & A. nidulans & & 0 & \\
\hline 13 & A. nidulans & & 0 & \\
\hline 14 & A. nidulans & & 0 & \\
\hline 15 & A. nidulans & & 0 & \\
\hline 16 & A. nidulans & & 0 & \\
\hline 17 & A. nidulans & & 0 & \\
\hline 18 & A. nidulans & & 0 & \\
\hline 19 & A. nidulans & & 0 & \\
\hline 20 & A. nidulans & & 0 & \\
\hline 1 & P. expansum & \multirow{20}{*}{13.716} & 0 & \multirow{20}{*}{0.0257} \\
\hline 2 & P. expansum & & 0 & \\
\hline 3 & P. expansum & & 0 & \\
\hline 4 & P. expansum & & 0 & \\
\hline 5 & P. expansum & & 0 & \\
\hline 6 & P. expansum & & 1.62 & \\
\hline 7 & P. expansum & & 0 & \\
\hline 8 & P. expansum & & 0 & \\
\hline 9 & P. expansum & & 0 & \\
\hline 10 & P. expansum & & 0 & \\
\hline 11 & P. expansum & & 0 & \\
\hline 12 & P. expansum & & 0 & \\
\hline 13 & P. expansum & & 0 & \\
\hline 14 & P. expansum & & 0 & \\
\hline 15 & P. expansum & & 0 & \\
\hline 16 & P. expansum & & 0 & \\
\hline 17 & P. expansum & & 0 & \\
\hline 18 & P. expansum & & 0 & \\
\hline 19 & P. expansum & & 0 & \\
\hline 20 & P. expansum & & 0 & \\
\hline 1 & T. harzianum & \multirow{20}{*}{20.486} & 0 & \multirow{20}{*}{0.0059} \\
\hline 2 & T. harzianum & & 0 & \\
\hline 3 & T. harzianum & & 0 & \\
\hline 4 & T. harzianum & & 0 & \\
\hline 5 & T. harzianum & & 0 & \\
\hline 6 & T. harzianum & & 0 & \\
\hline 7 & T. harzianum & & 0 & \\
\hline 8 & T. harzianum & & 0 & \\
\hline 9 & T. harzianum & & 1.37 & \\
\hline 10 & T. harzianum & & 0 & \\
\hline 11 & T. harzianum & & 0 & \\
\hline 12 & T. harzianum & & 0 & \\
\hline 13 & T. harzianum & & 0 & \\
\hline 14 & T. harzianum & & 0 & \\
\hline 15 & T. harzianum & & 0 & \\
\hline 16 & T. harzianum & & 0 & \\
\hline 17 & T. harzianum & & 0 & \\
\hline 18 & T. harzianum & & 0 & \\
\hline 19 & T. harzianum & & 0 & \\
\hline 20 & T. harzianum & & 0 & \\
\hline
\end{tabular}

To be continued 
Table A.4.4 Continuation

\begin{tabular}{|c|c|c|c|c|}
\hline Observation number & Treatment & First F dur (sec) & Total feeding (\%) & Contacts prior $F$ (freq) \\
\hline 1 & A. nidulans wounded & 92.511 & 18.47 & 0.0021 \\
\hline 2 & A. nidulans wounded & \multirow[t]{4}{*}{55.246} & 4.86 & \multirow[t]{4}{*}{0.0434} \\
\hline 3 & A. nidulans wounded & & 0 & \\
\hline 4 & A. nidulans wounded & & 0 & \\
\hline 5 & A. nidulans wounded & & 0 & \\
\hline 6 & A. nidulans wounded & 71.950 & 7.24 & 0.0073 \\
\hline 7 & A. nidulans wounded & \multirow[t]{3}{*}{11.074} & 4.24 & \multirow[t]{3}{*}{0.0145} \\
\hline 8 & A. nidulans wounded & & 0 & \\
\hline 9 & A. nidulans wounded & & 0 & \\
\hline 10 & A. nidulans wounded & \multirow[t]{5}{*}{17.665} & 2.83 & \multirow[t]{5}{*}{0.1669} \\
\hline 11 & A. nidulans wounded & & 0 & \\
\hline 12 & A. nidulans wounded & & 0 & \\
\hline 13 & A. nidulans wounded & & 0 & \\
\hline 14 & A. nidulans wounded & & 0 & \\
\hline 15 & A. nidulans wounded & \multirow[t]{5}{*}{263.512} & 28.57 & \multirow[t]{5}{*}{0.0147} \\
\hline 16 & A. nidulans wounded & & 0 & \\
\hline 17 & A. nidulans wounded & & 0 & \\
\hline 18 & A. nidulans wounded & & 0 & \\
\hline 19 & A. nidulans wounded & & 0 & \\
\hline 20 & A. nidulans wounded & 12.975 & 0.87 & 0.0068 \\
\hline 1 & P. expansum wounded & & 0 & \\
\hline 2 & P. expansum wounded & & 0 & \\
\hline 3 & P. expansum wounded & & 0 & \\
\hline 4 & P. expansum wounded & & 0 & \\
\hline 5 & P. expansum wounded & & 0 & \\
\hline 6 & P. expansum wounded & & 0 & \\
\hline 7 & P. expansum wounded & & 0 & \\
\hline 8 & P. expansum wounded & & 0 & \\
\hline 9 & P. expansum wounded & & 0 & \\
\hline 10 & P. expansum wounded & & 0 & \\
\hline 11 & P. expansum wounded & & 0 & \\
\hline 12 & P. expansum wounded & & 0 & \\
\hline 13 & P. expansum wounded & & 0 & \\
\hline 14 & P. expansum wounded & & 0 & \\
\hline 15 & P. expansum wounded & & 0 & \\
\hline 16 & P. expansum wounded & & 0 & \\
\hline 17 & P. expansum wounded & & 0 & \\
\hline 18 & P. expansum wounded & & 0 & \\
\hline 19 & P. expansum wounded & & 0 & \\
\hline 20 & P. expansum wounded & 12.982 & 0.87 & 0.0066 \\
\hline 1 & T. harzianum wounded & & 0 & \\
\hline 2 & T. harzianum wounded & & 0 & \\
\hline 3 & T. harzianum wounded & & 0 & \\
\hline 4 & T. harzianum wounded & & 0 & \\
\hline 5 & T. harzianum wounded & 140.757 & 10.68 & 0.0109 \\
\hline 6 & T. harzianum wounded & & 0 & \\
\hline 7 & T. harzianum wounded & & 0 & \\
\hline 8 & T. harzianum wounded & & 0 & \\
\hline 9 & T. harzianum wounded & & 0 & \\
\hline 10 & T. harzianum wounded & & 0 & \\
\hline 11 & T. harzianum wounded & & 0 & \\
\hline 12 & T. harzianum wounded & & 0 & \\
\hline 13 & T. harzianum wounded & & 0 & \\
\hline 14 & T. harzianum wounded & & 0 & \\
\hline 15 & T. harzianum wounded & & 0 & \\
\hline 16 & T. harzianum wounded & & 0 & \\
\hline 17 & T. harzianum wounded & & 0 & \\
\hline 18 & T. harzianum wounded & & 0 & \\
\hline 19 & T. harzianum wounded & & 0 & \\
\hline 20 & T. harzianum wounded & & 0 & \\
\hline
\end{tabular}

To be continued 


\section{Table A.4.4 Continuation}

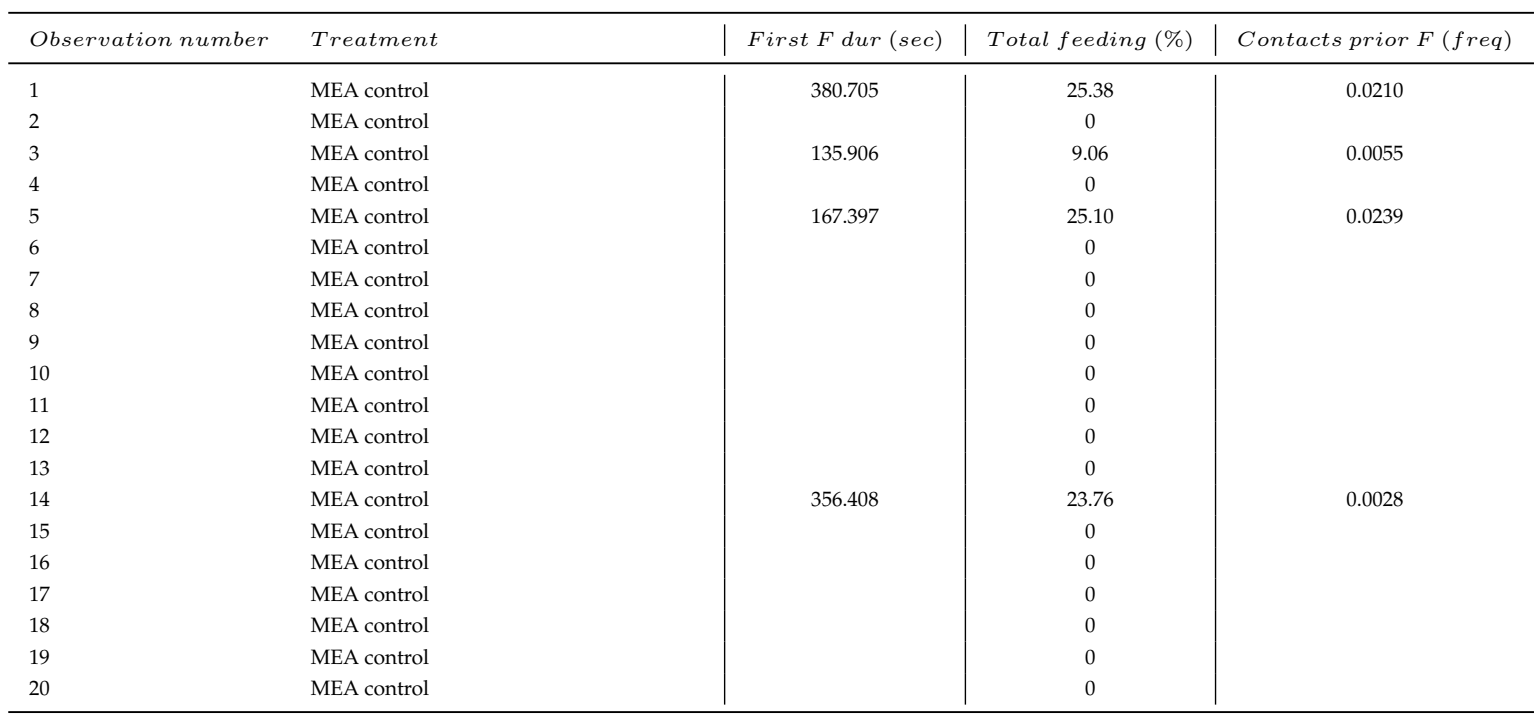




\section{Chapter}

\section{FINAL DISCUSSION}

In the light of their ubiquity, high diversity, abundance, and occurrence as primary colonisers, saprotrophic fungi are considered as major decomposers and key regulators of nutrient cycling in terrestrial ecosystems (Baldrian and Valášková 2008, Hättenschwiler et al. 2005. Kjoller and Struwe 1982, Watkinson et al. 2006). Increasing research on functional and ecological consequences of decomposer fungus-invertebrate interactions revealed that the interplay of fungi and soil animals plays a major role in shaping decomposition rates and related ecosystem processes. Primary colonisation and pre-decomposition of litter by fungi has been shown to enable or facilitate secondary colonisation by soil invertebrate decomposers and consequently affects the structure of soil faunal communities and population sizes (e.g. A'Bear et al. 2014a, Klironomos and Kendrick|1995, Men'ko et al.|2006, Richter 1979. Soma and Saito 1983, Wood et al. 2012, Zimmer and Topp 1997; 2000). Vice versa a wealth of studies has demonstrated that invertebrate fungal grazers directly affect the composition and activity of soil fungal communities by influencing enzyme activity, suppressing or encouraging fungal growth and altering amounts of competition via selective feeding and dispersal of fungal propagules and thus indirectly affect rates of decomposition and nutrient release (A'Bear et al.|2014a b, Crowther et al.|2012; 2011a b b c, David|2014, Hanlon and Anderson 1979, Jacobsen et al. 2017). Although the majority of soil invertebrates are considered as generalists that cover their nutritional requirements by feeding on a broad range of food sources, food-preference tests, stable isotope and gut content analysis revealed that fungi play a significant role in the diet of springtails, oribatid mites, annelids, isopods, diplopods, and molluscs (e.g. Anderson and Healey 1972, Berg et al. 2004, Kayang et al. 1996, Maraun et al. 2003, Pollierer et al. 2007, Ruf et al. 2006, Soma and Saito 1983, Zimmer 2002). Besides serving as food source for fungivorous invertebrates and acting as niche constructors for secondary colonisers, due to their diverse lifestyles fungi further directly and indirectly influence the performance of other soil organisms by serving as host, acting as pathogens and predators, and mediating multitrophic interactions (Chapter 1). A grand challenge in terrestrial ecology is to reveal the importance of ecological interactions and their direct and 
indirect effects on ecosystem processes. With focus on the role of fungal-derived volatiles in mediating fungus-arthropod interactions, the present $\mathrm{PhD}$ project represents a further step towards a better understanding of the underlying mechanisms that shape the character of fungus-arthropod interactions.

\subsection{THE ROLE OF FUNGAL VOLATILE OXYLIPINS IN MODULATING THE FORAGING BEHAVIOUR OF FUNGIVOROUS ARTHROPODS}

The constitutive production and wounding-related activation/increase of oxylipin compounds is a conserved mechanism in plants and higher fungi and oxylipins are well known to fulfil multiple functions as growth regulators and, most notably, as communication signals and infochemicals in both aboveground plant-insect (e.g. Bruce et al. 2005, Heil 2014) and belowground fungus-invertebrate interactions (Holighaus and Rohlfs 2018, Tsitsigiannis and Keller 2007) Chapter 1). Contrary to my expectations, the results of behavioural observations only partly confirm the hypothesis that fungal oxylipin volatiles function as food-finding cues for Collembola and isopods and that tissue wounding-related changes in fungal volatile profiles are used by these soil animals to make adaptive foraging and feeding decisions.

Independent of the wounding treatment, volatile emissions derived from fungal colonies attracted isopods and the mere presence of the common ubiquitous oxylipin volatile 3octanone arrested them in close proximity to the volatile source. On the one hand this finding indicates that $O$. asellus isopods may not be able to perceive wounding-related changes in oxylipin emissions, and on the other hand suggests that 3-octanone functions as cue, most likely along with other fungal volatiles, that may help isopods to locate favourable microhabitats and feeding sites characterised by high microbial activity (Chapter 3). This supports (Zimmer et al.1996) who observed attraction of $P$. scaber isopods to microbe-colonised litter. While studies by Zidar et al. (2003) and Gunnarsson (1987) suggest that food selection by $O$. asellus isopods requires physical contact to the fungal food source, the results of the present study for the first time demonstrate that these animals indeed use fungal-derived volatiles as infochemicals during foraging. Whereas the effect of fungal tissue wounding on the behaviour of isopods was only tested with respect to one fungal species (C. globosum) and restricted to the searching phase of food selection without physical contact, responses of 
Collembola were observed in the presence of different fungal species and in more detail by additionally investigating the behaviour with direct contact to fungi to find out whether wounding-related increases in oxylipin emissions increase the acceptance fungi as food source. Similar to isopods, volatile-mediated movement patterns of hemi- and epedaphic Collembola F. candida, S. curviseta, $H$. nitidus were not affected by the wounding treatment. Since GC-MS analyses revealed significant differences in wounding-specific volatile profiles between the tested fungal species, A. nidulans, P. expansum, T. harzianum (Chapter 4, and C. globosum (Chapter 2), I assume that Collembola are generally not able to use woundactivated increases in oxylipin emissions to accelerate and optimise the food-finding process (Chapter 2, 4).

On the contrary, oxylipins, 3-octanone in particular, become relevant when Collembola get in contact with fungal colonies. Although responses of the three Collembola species to unwounded and wounded C. globosum colonies differed, altogether the results point to higher acceptance of wounded colonies as food source. Moreover, 3-octanone elicited test-biting behaviour in F. candida and S. curviseta suggesting that this common mushroom volatile functions as phagostimulant for Collembola. Test-biting behaviour has never been observed before in Collembola but frequently in herbivorous insects (e.g. Chapman and Bernays 1989. Schoonhoven et al. 2005). In the light of the finding that the wound-activated increase of 3octanone in A. nidulans, P. expansum, T. harzianum did not affect the acceptance of these fungi as food source by F. candida, it can be assumed that the volatile background, i.e. the presence of other presumably deterrent volatile and/or non-volatile compounds, diminishes or erases the phagostimulant effect of 3-octanone.

\subsection{COLLEMbOla Distinguish BETWEEN SUITABLE AND LESS SUITABLE FUNGAL FOOD SOURCES BY MEANS OF VOLATILES}

Soil fungal communities not only comprise filamentous fungi but also a significant number of unicellular yeasts (Esteve-Zarzoso et al. 1999). While spores of filamentous fungi are primarily dispersed by wind, yeasts rely on animals that vector cells to new substrates; furthermore, due to their unicellular growth and nutritious value yeast present an easily consumable highly suitable food source (Blackwell 2017). Therefore, mutualistic relationships between yeasts and soil invertebrates are not seldom (Blackwell 2017) and yeast-derived 
volatiles have frequently been shown to play an important role in mediating contact between the mutualist partners by acting as host-, food-, or habitat-finding cues (Chapter 1). In contrast, a range of filamentous fungi produces harmful and/or deterrent secondary metabolites that are supposed to have been evolved to defend against fungivory (Brandt et al. 2017, Kempken and Rohlfs 2010, Rohlfs et al. 2007, Sherratt et al. 2005, Stötefeld et al. 2012). In the light of these differences, I hypothesised that yeasts and filamentous fungi differ in their volatile emissions and that Collembola use characteristics in volatile profiles to differentiate between suitable and less suitable fungi.

Overall, the results confirm this hypothesis. Volatile-mediated responses to yeasts (C. terricola, M. pulcherrima, T. dulcitum) and filamentous fungi (A. nidulans, P. expansum, T. harzianum) were largely reflected in the acceptance and rejection of the tested fungi as food source and finally in the growth (changes in body size) and reproduction (number of eggs) when these fungi where given as single diet for 12 days, indicating that F. candida Collembola are indeed able to differentiate between suitable and less suitable fungi from a short distance $(\sim 3 \mathrm{~cm})$ by means of volatile cues (Chapter 4 ). Responses to yeasts, however, were more unambiguous than those observed in the presence of the filamentous fungi. Contrasting effects may be explained by differences in fungal volatile profiles. More specifically, taking into account the results of the volatile profiling, the higher attractivity and/or acceptance of the yeasts and the filamentous fungus $A$. nidulans is likely due to low quantities of volatile emissions, the presence of the short-chain alcohol 3-methyl-1-butanol, and the absence of terpenoid compounds. The morphological properties of the tested fungi could be another factor possibly influencing the acceptance of fungal colonies as food source. While the tested yeasts grow unicellular, the filamentous fungi form a dense mesh of hyphae and spores which may impede Collembola from accessing and feeding on respective fungal colonies. Furthermore, the formation of sticky clumps of conidia characteristic for Trichoderma spp. may also play a role in influencing the acceptance as food source. This aspect needs to be tested in future studies.

Interestingly, exclusively the volatile bouquet of the filamentous fungus P. expansum had a deterrent effect, Collembola rejected this fungus as food source, indicated by an extremely low feeding activity, reproduction, and insignificant increase in growth. The observed deterrent effect of the P. expansum characteristic compound geosmin (trans-1,10-di-methyl-trans9-decalol) strongly suggests that this compound, likely along with other deterrent and/or toxic volatile and/or non-volatile compounds, functions as chemical defence against fungivory and it can be assumed that Collembola are able to use respective compounds to de- 
tect and avoid contact with harmful and unsuitable fungi. This assumption is strengthened by previous studies that also point out deterrent effects of geosmin (Stensmyr et al. 2012) and other P. expansum characteristic volatiles (Azeem et al.2013) and its unsuitability as food source (Heděnec et al. 2013).

\subsection{CONCLUSION AND OUTLOOK}

Overall, the results of the present $\mathrm{PhD}$ project provide further evidence for the importance of fungal chemical properties, fungal volatiles in particular, in affecting the outcome of fungusarthropod interactions, as it has already been suggested by earlier studies (Böllmann et al. 2010, Rohlfs 2015, Rohlfs et al. 2007, Rohlfs and Churchill 2011, Stötefeld et al. 2012). I could clearly demonstrate that two important decomposers - Collembola and isopods - use fungalderived volatiles as cues to make adaptive foraging decisions. In the light of the finding that Collembola are able to discriminate between fungi of varying suitability by detecting and responding to characteristics in fungal volatile profiles, it can be assumed that the use of volatile cues is an important, hitherto underestimated and underexplored, aspect of the food-selection process of Collembola and represents a mechanism that leads to fitness optimisation. Whether the emission of certain volatiles by filamentous fungi actually functions as defense needs to be tested by directly linking volatile-mediated responses of animals to the fitness of fungi, which can be best achieved for example by the use of genetically manipulated fungi deficient in the production of suspected deterrent volatiles.

Research on the function of fungal volatiles as infochemicals in fungus-invertebrate interactions is challenged by the high diversity of fungal-derived volatiles (Chiron and Micherlot 2005), synergistic effects between volatile compounds, as well as the high species-, genotype-, growth stage-, and physical state-related variability of fungal volatile emission and their dependency on the growth substrate (e.g. Börjesson et al. 1992, Combet et al. 2009, Fiedler et al. 2001, Gallois et al. 1990, Splivallo et al.|2012, Sunesson et al.|1995) (Chapter 4, and synergistic effects. It becomes even more complicated in the light of the world's vast diversity of fungal species with estimates between 500 thousand to 9.9 million (Hawksworth 2001) and their cryptic lifestyle. Future studies need to consider and incorporate this variation. Especially the importance of oxylipin volatiles as infochemicals in soil fungus-arthropod interactions needs to be investigated in further detail to find out whether fungal-derived oxylipins are of 
similar importance for soil living arthropods as plant-derived oxylipins for herbivorous insects. Future studies need to include further species of fungivorous arthropods and should consider single but also synergistic and/or additive effects of different fungal volatiles e.g. by means of additive and subtractive methods. In the present study I could demonstrate that a video-based direct observation approach of the foraging responses of arthropods during both the searching (off-patch) and contact phase (on-patch) is a suitable method for gaining more detailed information on the overall food selection process.

Considering the opaque nature and complexity of soil habitats observations in natural environments are complicated. The advantage of laboratory experiments is the possibility to manipulate and control influencing variables, which facilitates conclusions and predictions of simple cause and effect relationships; nevertheless, carrying out experiments in more natural environments is crucial for the validation of effects in natural habitats. Investigation of fungus-arthropod interactions in semi-natural environments by means of microcosms experiments has been shown to be an appropriate approach to gain insights into complex interrelationships between organisms and environmental factors. Furthermore, an increasing number of studies show that the microcosm approach allows to measure ecosystem relevant impacts of organismic interactions, e.g. population dynamics, food-web structures, decomposition rates, nutrient distribution and -cycling (A'Bear et al.|2014b). 


\section{REFERENCES}

A'Bear AD, Boddy L, Kandeler E, Ruess L, and Jones TH, 2014a. Effects of isopod population density on woodland decomposer microbial community function. Soil Biology and Biochemistry, 77:112-120. ISSN 00380717. doi:10.1016/j.soilbio.2014.05.031.

A'Bear AD, Jones TH, and Boddy L, 2014b. Size matters: what have we learnt from microcosm studies of decomposer fungus-invertebrate interactions? Soil Biology and Biochemistry, 78:274-283. ISSN 00380717. doi:10.1016/j.soilbio.2014.08.009.

Anderson J and Healey I, 1972. Seasonal and inter-specific variation in major components of the gut contents of some woodland Collembola. Journal of Animal Ecology, 41(2):359-368. doi: $10.2307 / 3473$.

Azeem M, Rajarao GK, Nordenhem H, Nordlander G, and Borg-Karlson AK, 2013. Penicillium expansum volatiles reduce pine weevil attraction to host plants. Journal of Chemical Ecology, 39(1):120-128. ISSN 1573-1561. doi:10.1007/s10886-012-0232-5.

Baldrian P and Valášková V, 2008. Degradation of cellulose by basidiomycetous fungi. FEMS Microbiology Reviews, 32(3):501-521. ISSN 01686445. doi:10.1111/j.1574-6976.2008.00106.x.

Berg MP, Stoffer M, and Van Den Heuvel HH, 2004. Feeding guilds in Collembola based on digestive enzymes. Pedobiologia, 48(5-6):589-601. ISSN 00314056. doi:10.1016/j.pedobi. 2004.07.006.

Blackwell M, 2017. Made for each other: ascomycete yeasts and insects. The Fungal Kingdom, pages 945-962. doi:10.1128/microbiolspec.FUNK-0081-2016.

Böllmann J, Elmer M, Wöllecke J, Raidl S, and Hüttl RF, 2010. Defensive strategies of soil fungi to prevent grazing by Folsomia candida (Collembola). Pedobiologia, 53(2):107-114. ISSN 00314056. doi:10.1016/j.pedobi.2009.06.003.

Börjesson T, Stollman U, and Schnurer J, 1992. Volatile metabolites produced by 6 fungal species compared with other indicators of fungal growth on cereal-grains. Applied and Environmental Microbiology, 58(8):2599-2605.

Brandt P, García-Altares M, Nett M, Hertweck C, and Hoffmeister D, 2017. Induced chemical defense of a mushroom by a double-bond-shifting polyene synthase. Angewandte Chemie International Edition, 56:1-6. ISSN 14337851. doi:10.1002/anie.201700767.

Bruce TJA, Wadhams LJ, and Woodcock CM, 2005. Insect host location: a volatile situation. Trends in Plant Science, 10(6):269-274. ISSN 13601385. doi:10.1016/j.tplants.2005.04.003.

Chapman RF and Bernays EA, 1989. Insect behavior at the leaf surface and learning as aspects of host plant selection. Experientia, 45(3):215-222. ISSN 00144754. doi:10.1007/ BF01951806.

Chiron N and Micherlot D, 2005. Odeurs des champignons: chimie et rôle dans les interactions biotiques - une revue. Cryptogamie, Mycologie, 26(4):299-364. 
Combet E, Henderson J, Eastwood DC, and Burton KS, 2009. Influence of sporophore development, damage, storage, and tissue specificity on the enzymic formation of volatiles in mushrooms (Agaricus bisporus). Journal of Agricultural and Food Chemistry, 57(9):3709-3717. ISSN 00218561. doi:10.1021/jf8036209.

Crowther TW, Boddy L, and Hefin Jones T, 2012. Functional and ecological consequences of saprotrophic fungus-grazer interactions. The ISME Journal, 6(11):1992-2001. ISSN 17517370. doi:10.1038/ismej.2012.53.

Crowther TW, Boddy L, and Jones TH, 2011a. Outcomes of fungal interactions are determined by soil invertebrate grazers. Ecology Letters, 14(11):1134-1142. ISSN 1461023X. doi:10.1111/j.1461-0248.2011.01682.x.

Crowther TW, Boddy L, and Jones TH, 2011b. Species-specific effects of soil fauna on fungal foraging and decomposition. Oecologia, 167(2):535-545. ISSN 00298549. doi:10.1007/ s00442-011-2005-1.

Crowther TW, Jones TH, Boddy L, and Baldrian P, 2011c. Invertebrate grazing determines enzyme production by basidiomycete fungi. Soil Biology and Biochemistry, 43(10):20602068. ISSN 00380717. doi:10.1016/j.soilbio.2011.06.003.

David JF, 2014. The role of litter-feeding macroarthropods in decomposition processes: a reappraisal of common views. Soil Biology and Biochemistry, 76:109-118. ISSN 00380717. doi:10.1016/j.soilbio.2014.05.009.

Esteve-Zarzoso B, Belloch C, Uruburu F, and Querol A, 1999. Identification of yeasts by RFLP analysis of the 5.8S rRNA gene and the two ribosomal internal transcribed spacers. International Journal of Systematic Bacteriology, 49(1):329-337. ISSN 0020-7713. doi:10.1099/ 00207713-49-1-329.

Fiedler K, Schütz E, and Geh S, 2001. Detection of microbial volatile organic compounds (MVOCs) produced by moulds on various materials. International Journal of Hygiene and Environmental Health, 204(2-3):111-121. ISSN 1438-4639. doi:10.1078/1438-4639-00094.

Gallois A, Gross B, Langlois D, Spinnler HE, and Brunerie P, 1990. Influence of culture conditions on production of flavour compounds by 29 ligninolytic basidiomycetes. Mycological Research, 94(4):494-504. ISSN 09537562. doi:10.1016/S0953-7562(10)80010-3.

Gunnarsson T, 1987. Selective feeding on a maple leaf by Oniscus asellus (Isopoda). Pedobiologia, 30:161-165.

Hanlon RDG and Anderson JM, 1979. The effects of collembola grazing on microbial activity in decomposing leaf litter. Oecologia, 99:93-99. doi:10.1007/BF00347827.

Hättenschwiler S, Tiunov A, and Scheu S, 2005. Biodiversity and litter deomposition in terrestrial ecosystems. Annual Review of Ecology and Evolution, 36:191-218. ISSN 1543592X. doi:10.1146/annurev.ecolsys.36.112904.151932.

Hawksworth DL, 2001. The magnitude of fungal diversity: the 1.5 million species estimated revisited. Mycological Research, 105(December):1422-1432. doi:10.1017/ S0953756201004725. 
Heděnec P, Radochová P, Nováková A, Kaneda S, and Frouz J, 2013. Grazing preference and utilization of soil fungi by Folsomia candida (Isotomidae: Collembola). European Journal of Soil Biology, 55:66-70. ISSN 11645563. doi:10.1016/j.ejsobi.2012.12.005.

Heil M, 2014. Herbivore-induced plant volatiles: targets, perception and unanswered questions. Journal of Physiology, 204(2):297-306. ISSN 14697793. doi:10.1111/nph.12977.

Holighaus G and Rohlfs M, 2018. Volatile and non-volatile fungal oxylipins in fungus invertebrate interactions. Fungal Ecology (in press). doi:10.1016/j.funeco.2018.09.005.

Jacobsen RM, Kauserud H, Sverdrup-Thygeson A, Bjorbækmo MM, and Birkemoe T, 2017. Wood-inhabiting insects can function as targeted vectors for decomposer fungi. Fungal Ecology, 29:76-84. ISSN 17545048. doi:10.1016/j.funeco.2017.06.006.

Kayang DDH, Sharma GD, and Mishra RR, 1996. The influence of isopod grazing on microbial dynamics in decomposing leaf litter of Alnus nepalensis. European Journal of Soil Biology, 32(1):35-39. ISSN 11645563.

Kempken F and Rohlfs M, 2010. Fungal secondary metabolite biosynthesis - a chemical defence strategy against antagonistic animals? Fungal Ecology, 3(3):107-114. ISSN 17545048. doi:10.1016/j.funeco.2009.08.001.

Kjoller A and Struwe S, 1982. Microfungi in ecosystems: fungal occurrence and activity in litter and soil. Nordic Society Oikos, 39(3):391-422. ISSN 0030-1299. doi:10.2307/3544690.

Klironomos JN and Kendrick WB, 1995. Relationships among microartropods, fungi, and their environment. Plant and Soil, 170:183-197. ISSN 0032-079X. doi:10.1007/BF02183066.

Maraun M, Martens H, Migge S, Theenhaus A, and Scheu S, 2003. Adding to 'the enigma of soil animal diversity': fungal feeders and saprophagous soil invertebrates prefer similar food substrates. European Journal of Soil Biology, 39(2):85-95. ISSN 11645563. doi:10.1016/ S1164-5563(03)00006-2.

Men'ko EV, Chernov II, and Byzov Ba, 2006. Interrelationships between yeast fungi and collembolans in soil. Mikrobiologiia, 75(6):814-822. ISSN 0026-2617. doi:10.1134/ S0026261706060142.

Pollierer MM, Langel R, Körner C, Maraun M, and Scheu S, 2007. The underestimated importance of belowground carbon input for forest soil animal food webs. Ecology Letters, 10(8):729-736. ISSN 1461023X. doi:10.1111/j.1461-0248.2007.01064.x.

Richter K, 1979. Aspects of nutrient cycling by Ariolimax columbianus (Mollusca: Arionidae) in Pacific Northwest coniferous forests. Pedobiologia, 19:60-74.

Rohlfs M, 2015. Fungal secondary metabolite dynamics in fungus-grazer interactions: novel insights and unanswered questions. Frontiers in Microbiology, 6(JAN):1-5. ISSN 1664302X. doi:10.3389/fmicb.2014.00788.

Rohlfs M, Albert M, Keller NP, and Kempken F, 2007. Secondary chemicals protect mould from fungivory. Biology Letters, 3:523-525. ISSN 1744-9561. doi:10.1098/rsbl.2007.0338.

Rohlfs M and Churchill ACL, 2011. Fungal secondary metabolites as modulators of interactions with insects and other arthropods. Fungal Genetics and Biology, 48(1):23-34. ISSN 10871845. doi:10.1016/j.fgb.2010.08.008. 
Ruf A, Kuzyakov Y, and Lopatovskaya O, 2006. Carbon fluxes in soil food webs of increasing complexity revealed by $14 \mathrm{C}$ labeling and 13C natural abundance. Soil Biology $\mathcal{E}$ Biochemistry, 38:2390-2400. doi:10.1016/j.soilbio.2006.03.008.

Schoonhoven LM, van Loon JJA, and Dicke M, 2005. Insect-plant biology. Oxford University Press, New York, 2 edition. ISBN 978-0-19-852594-3.

Sherratt TN, Wilkinson DM, and Bain RS, 2005. Explaining Dioscorides' "double difference": why are some mushrooms poisonous, and do they signal their unprofitability? The American Naturalist, 166(6):767-775. ISSN 0003-0147. doi:10.1086/497399.

Soma K and Saito T, 1983. Ecological studies of soil organisms with references to the decomposition of pine needles. II. Litter feeding and breakdown by the woodlouse, Porcellio scaber. Plant and Soil, 75(1):139-151. doi:10.1007/bf02178621.

Splivallo R, Valdez N, Kirchhoff N, Ona MC, Schmidt JP, Feussner I, and Karlovsky P, 2012. Intraspecific genotypic variability determines concentrations of key truffle volatiles. New Phytologist, 194(3):823-835. ISSN 0028646X. doi:10.1111/j.1469-8137.2012.04077.x.

Stensmyr MC, Dweck HKM, Farhan A, Ibba I, Strutz A, Mukunda L, Linz J, Grabe V, Steck K, Lavista-Llanos S, Wicher D, Sachse S, Knaden M, Becher PG, Seki Y, and Hansson BS, 2012. A conserved dedicated olfactory circuit for detecting harmful microbes in Drosophila. Cell, 151(6):1345-1357. ISSN 00928674. doi:10.1016/j.cell.2012.09.046.

Stötefeld L, Scheu S, and Rohlfs M, 2012. Fungal chemical defence alters density-dependent foraging behaviour and success in a fungivorous soil arthropod. Ecological Entomology, 37(5):323-329. ISSN 03076946. doi:10.1111/j.1365-2311.2012.01373.x.

Sunesson A, Vaes W, Nilsson C, Blomquist G, Andersson B, Sunesson Al, Vaes WHJ, and Nilsson Ca, 1995. Identification of volatile metabolites from five fungal species cultivated on two media. Applied and Environmental Microbiology, 61(8):2911-2918.

Tsitsigiannis DI and Keller NP, 2007. Oxylipins as developmental and host-fungal communication signals. Trends in Microbiology, 15(3):109-118. ISSN 0966842X. doi:10.1016/j.tim. 2007.01.005.

Watkinson SC, Bebber D, Darrah P, Fricker M, Tlalka M, and Boddy L, 2006. The role of wood decay fungi in the carbon and nitrogen dynamics of the forest floor. In G Gadd, editor, Fungi in biogeochemical cycles, pages 151-181. Cambridge University Press. ISBN 0521845793. doi:10.2277/0521845793.

Wood CT, Schlindwein CCD, Soares GLG, and Araujo PB, 2012. Feeding rates of Balloniscus sellowii (Crustacea, Isopoda, Oniscidea): the effect of leaf litter decomposition and its relation to the phenolic and flavonoid content. ZooKeys, 176(SPECIAL ISSUE):231-245. ISSN 13132989. doi:10.3897/zookeys.176.1940.

Zidar P, Kaschl U, Drobne D, Bozic J, and Strus J, 2003. Behavioural responses in paired food choice experiments with Oniscus asellus (Crustacea, Isopoda) as an indicator of different food quality. Arhiv Za Higijenu Rada I Toksikologiju, 54:177-181.

Zimmer M, 2002. Nutrition in terrestrial isopods (Isopoda: Onisicdea): an evolutionaryecological aprroach. Biological Reviews, 77:455-493. doi:10.1017/S1464793102005912. 
Zimmer M, Kautz G, and Topp W, 1996. Olfaction in terrestrial isopods (Crustacea: Oniscidea): responses of Porcellio scaber to the odour of litter. European Journal of Soil Biology, 32(3):141-147.

Zimmer M and Topp W, 1997. Does leaf litter quality influence population parameters of the common woodlouse, Porcellio scaber Latr., 1804 (Crustacea: Isopoda). Biology and Fertility of Soils, 24:435-441. ISSN 01782762. doi:10.1007/s003740050269.

Zimmer M and Topp W, 2000. Species-specific utilization of food sources by sympatric woodlice (Isopoda: Oniscidea). Journal of Animal Ecology, 69(6):1071-1082. doi:10.1111/j. 1365-2656.2000.00463.x. 


\section{DANKSAGUNG}

Die ersten Worte des Dankes möchte ich an meinen Doktorvater Marko Rohlfs richten. Insbesondere danke ich Marko Rohlfs für seine große Begeisterung für die chemischen und verhaltensbasierten Aspekte ökologischer Zusammenhänge, die er bereits während meines Bachelor- und Masterstudiums auch in mir entfachte. Seine Anregungen und unsere motivierenden Diskussionen ermöglichten es mir nicht nur eigene Forschungsideen zu entwickeln und schließlich in einem Promotionsprojekt zu verwirklichen, sondern auch die von Zeit zu Zeit auftauchenden Herausforderungen unterschiedlichster Art zu meistern.

Großer Dank gebührt auch meinem Zweitbetreuer Stefan Scheu, der mich in die AG Tierökologie aufgenommen und damit den Weg für meine Forschung geebnet hat. Darüberhinaus möchte ich mich bei der gesamten AG für das angenehme Arbeitsklima, erquickende Gespräche und die stete Hilfsbereitschaft bedanken. Ingrid Kleinhans, Susanne BöningKlein, Guido Humpert, Dieter Nünchert, Bernd Messerschmidt, Dora Volovei und Andrea Lambertz danke ich für die praktische Unterstützung in bürokratischen sowie technischen Belangen in- und außerhalb des Labors.

Weiterhin möchte ich mich bei den Mitgliedern der Abteilung Forstzoologie bedanken. Ein großes Dankeschön an Ulrike Eisenwiener, Bernhard Weißbecker, Martin Gabriel, Christine Rachow, Sarah Nicke-Mühlfeit, Andreas Teichmann und Gerrit Holighaus für die technische Hilfestellung, die stets zuverlässige Hilfe bei der Beschaffung von flüssigem Stickstoff und für wohlsam erheiternde Gespräche während der Pausen. Gerrit Holighaus danke ich zudem für sein immer offenes Ohr für fachliche als auch weniger fachliche Angelegenheiten und für anregende Diskussionen über die hohe Kunst der gaschromatographischmassenspektrometrischen Analyse.

Meinem Stipendiengeber, dem Evangelischen Studienwerk Villigst, danke ich für die finanzielle sowie ideelle Unterstützung, die es mir ermöglicht hat meine Ideen im Rahmen der vorliegenden Doktorarbeit in die Tat umzusetzen.

Der größte Dank gebührt selbstverständlich meiner Familie. Meinen Eltern Edith und Hermann Stötefeld und meinem Bruder Patrick Stötefeld danke ich für die seelische als auch finanzielle Unterstützung während des Studiums und ihren unbedingten Glauben an mich. Meinem Partner Jan Rethmeier und meinem Hund Coco danke ich für unzählige schöne Momente, die Sicherheit in Momenten des Zweifels, dafür, dass sie Freud und Leid mit mir teilen und für so vieles mehr. 


\section{THESIS DECLARATIONS}

\section{DECLARATION OF THE AUTHOR'S OWN CONTRIBUTION TO MANUSCRIPTS WITH MULTIPLE AUTHORS}

In all manuscripts I am the first author and, with assistance of my supervisor Prof. Dr. Marko Rohlfs, I developed the main ideas and the study design.

Chapter 2: The 'substrate biting' experiment was conducted by Sandra Granzow during the course of her MSc thesis, the 'on-patch' experiment was conducted by Dominique Treschnak during the course of his BSc thesis, and I conducted the 'off-patch' experiment and the GCMS volatile profiling. I analysed all data, created tables, figures and appendices, and wrote the manuscript.

Chapter 3 and Chapter 4: I collected and analysed the data, created tables, figures and appendices, and wrote the manuscript.

\section{Plagiarism declaration}

I declare that I have written this doctoral thesis independently. All persons contributing to the manuscripts have been named so. All sentences or passages quoted from other people's work have been specifically acknowledged by clear cross-referencing. I have not submitted this thesis in any form for another degree at any university or institution.

Laura Stötefeld

Göttingen, October 2018 